\title{
AVALIAÇÃO IN VITRO DA COMPOSIÇÃO E MICRODUREZA DOS TECIDOS DUROS DA CAVIDADE BUCAL SUBMETIDOS À IRRADIAÇÃO GAMA
}

\author{
WILBER EDISON BERNAOLA PAREDES
}

Dissertação apresentada como parte dos requisitos para obtenção do Grau de Mestre em Ciências na Área de Tecnologia Nuclear - Materiais

Orientador:

Prof. Dr. Delvonei Alves de Andrade 


\title{
INSTITUTO DE PESQUISAS ENERGÉTICAS E NUCLEARES
}

Autarquia associada à Universidade de São Paulo

\section{AVALIAÇÃO IN VITRO DA COMPOSIÇÃO E MICRODUREZA DOS TECIDOS DUROS DA CAVIDADE BUCAL SUBMETIDOS À IRRADIAÇÃO GAMA}

\author{
WILBER EDISON BERNAOLA PAREDES
}

Dissertação apresentada como parte dos requisitos para obtenção do Grau de Mestre em Ciências na Área de Tecnologia Nuclear - Materiais

Orientador:

Prof. Dr. Delvonei Alves de Andrade

\author{
Versão Corrigida \\ Versão Original disponível no IPEN
}

São Paulo 


\section{DEDICATÓRIA}

À Deus, por ser a razão de tudo na minha vida, pela motivação e força interior que me dá para continuar neste caminho.

Aos meus pais, Robert Wilber Bernaola Marcelo e Rosa Sofía Paredes Olaya, por serem os co-protagonistas e o arcabouço fundamental na minha educação nos diferentes níveis, e pela confiança e apoio incondicional durante toda minha vida. 


\section{AGRADECIMENTOS ESPECIAIS}

Ao meu orientador, Prof. Dr. Delvonei Alves de Andrade, pela recepção e a decisão

de orientar-me, e pelos ensinamentos ministrados para a conclusão deste trabalho de pesquisa. 


\section{AGRADECIMENTOS}

À Dra. Claudia Bianchi Zamataro, pela motivação desde o início do caminho, pelos ensinamentos e por ter acreditado e confiado em mim.

Aos colaboradores científicos do Centro de Lasers e Aplicações: Profa. Dra. Denise Maria Zezell, Daísa de Lima Pereira, Marcia Dias, Carolina Benetti, Camila Ramos, Lucas Ramos de Pretto.

À Profa. Dra. Áurea Beatriz Cerqueira Geraldo, pesquisadora titular do Centro de Tecnologia das Radiações, pelas suas orientações, apoio e conhecimentos fornecidos durante a execução do presente estudo.

Aos profissionais do Centro de Tecnologia das Radiações (CTR), pelo apoio e atenção durante a etapa da irradiação das amostras, pela responsabilidade e compromisso mostrado.

Às minhas amigas e confidentes, Rosangela, Antônia, Josefina e Aline, pela amizade, carinho e aconchego desde a minha chegada ao Centro de Lasers e Aplicações.

Ao pessoal da Biblioteca do IPEN “Terezine Arantes Ferraz”, pela amizade, carinho e ajuda durante a busca bibliográfica correspondente ao tema de estudo.

A todo o pessoal administrativo do Centro de Lasers e Aplicações, do Centro de Tecnologia das Radiações, os quais me apoiaram diariamente nos dias de trabalho, com suporte emocional e carinho, e pela disposição a me ajudar nos momentos de dificuldade.

Aos profissionais do Centro de Química e Meio Ambiente, CQMA, pelo material fornecido durante o período de preparo das amostras, pela disposição mostrada quando necessário.

A Comissão Nacional de Energia Nuclear - CNEN pelo auxílio financeiro para o desenvolvimento desta pesquisa.

A toda minha família Bernaola Paredes, aos meus amigos e a todas as pessoas em Lima no Peru e em Barcelona na Espanha, que de alguma forma fizeram parte desta 
caminhada na área acadêmica, gratidão pela confiança, apoio, compreensão e o amor oferecido. 


\title{
AVALIAÇÃO IN VITRO DA COMPOSIÇÃO E MICRODUREZA DOS TECIDOS DUROS DA CAVIDADE BUCAL SUBMETIDOS À IRRADIAÇÃO GAMA
}

\section{WILBER EDISON BERNAOLA PAREDES}

\begin{abstract}
RESUMO
A radioterapia clínica é de fundamental importância para o tratamento de lesões malignas localizadas na região de cabeça e pescoço, contudo, a exposição à irradiação ionizante, pode levar a complicações sistêmicas ou locais durante e após o tratamento radioterápico. Dentre estas complicações locais imediatas, destaca-se na cavidade oral a xerostomia e a consequente mucosite oral. A respeito das complicações tardias produzidas pela radioterapia, salientam-se a cárie de radiação e a osteorradionecrose, lesões dose dependentes, com alto nível de incidência nas últimas décadas e de difícil manejo, embora estas se apresentem após o término do tratamento e sob influência de fatores locais. A metodologia proposta no presente estudo visa analisar o efeito que exerce a radiação gama após a aplicação da radioterapia, utilizando-se a dose empregada em pacientes acometidos com câncer de cabeça e pescoço. As amostras foram obtidas a partir de esmalte dentário e dentina radicular humanos e osso mandibular suíno, as quais foram previamente polidas, e em seguida analisadas quanto à microdureza de superfície inicial de todos os grupos. Posteriormente, as amostras foram irradiadas sob uma taxa de dose de 4 Gy por dia, completando uma dose total de 72 Gy. Finalmente, as amostras foram submetidas a análise da microdureza de superfície após irradiação, a qual apresentou resultados estatisticamente significantes a partir dos testes de $t$ de student, ANOVA e Tukey com respeito à diferença da média dos valores iniciais e finais de cada grupo de estudo com um valor de $\mathrm{p}=0,00(<0.05)$. Quanto à análise morfológica na microscopia eletrônica de varredura (MEV), o efeito deletério da irradiação gama manifestou-se na forma de trincas, quebras e fraturas superficiais dos tecidos analisados e à análise bioquímica pela técnica de reflexão total atenuada por meio da espectroscopia no infravermelho por transformada de Fourier (ATR FTIR), a degradação dos componentes inorgânicos e a desnaturação dos compostos orgânicos
\end{abstract}


foi evidente, pelo qual determinou-se o efeito deletério da irradiação gama sobre os tecidos duros da cavidade bucal com respeito às propriedades mecânicas, composicionais e morfológicas, e da ação contribuinte desta independente dos fatores locais e sistêmicos no paciente irradiado. 


\title{
IN VITRO ASSESSMENT OF THE COMPOSITION AND MICROHARDNESS OF HARD TISSUES OF ORAL CAVITY SUBMITTED TO GAMMA IRRADIATION
}

\section{WILBER EDISON BERNAOLA PAREDES}

\begin{abstract}
Clinical Radiotherapy is extremely important for the treatment of malignant lesions of the head and neck region, however, exposure to ionizing radiation can lead to systemic or local complications during and after radiation treatment. Among these immediate local complications are the oral cavity xerostomia and the consequent oral mucositis. Regarding late complications produced by radiation, tooth decay of radiation and osteoradionecrosis are included, which are considered dose-dependent lesions, with high incidence in recent decades and difficult to manage, although these appear after completion of treatment and under the influence of local factors. The methodology proposed in this study consists in evaluating the effect of gamma radiation after irradiation of the samples, using the dose used in patients suffering with head and neck cancer. The samples were obtained from human enamel and root dentin; and swine mandibular bone, which were previously polished, and then submitted to the analysis of the initial surface microhardness of all groups. Subsequently, the samples were irradiated in a dose rate of 4 Gy per day, completing a total dose of 72 Gy. Finally, the samples were submitted to surface microhardness analysis after irradiation, which presented statistically significant results from the Student $t$, ANOVA and Tukey statistical tests referred to the difference of the mean of the initial and final values of each study group with a significant value of $p=0.00(<0.05)$. Regarding the morphological analysis in scanning electron microscopy (SEM), the deleterious effect of gamma irradiation was evidenced as structural cracks, breaks and superficial fractures of the analyzed tissues and the biochemical analysis by Attenuated Total Reflection technique using Fourier transform infrared spectroscopy (ATR - FTIR) showed degradation of inorganic components and denaturation of organic compounds; whereby, the effect of gamma irradiation on the hard tissues of the oral cavity with respect to mechanical, compositional and morphological
\end{abstract}


properties was deleterious and this study highlighted the isolated action of this ionizing radiation which contributes highly for its appearance, independent of local and systemic factors in the irradiated patients. 


\section{SUMÁRIO}

1. INTRODUÇÃ

2. OBJETIVO................................................................................................................................6

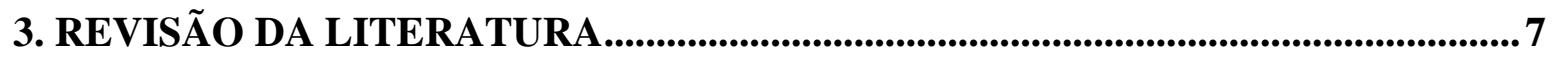

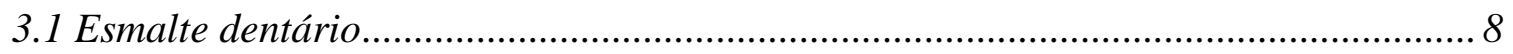

3. 1. 1 Propriedades físico - químicas do esmalte dentário …………………………..... 8

3. 1. 2 Análise da ultraestrutura dos tecidos mineralizados.......................................... 10

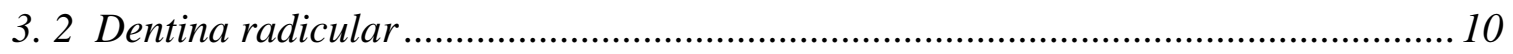

3. 2. 1 Propriedades físico - químicas da dentina ........................................................... 10

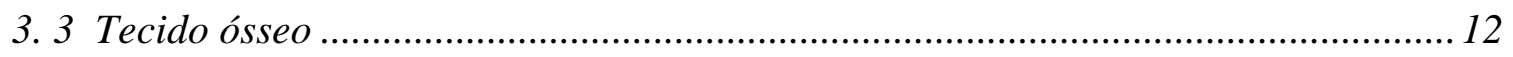

3. 3. 1 Matriz orgânica e ligações cruzadas de colágeno................................................. 12

3. 3. 2 Características anatômicas da mandíbula suína.................................................... 13

3. 3. 2. 1 Macroestrutura suína .............................................................................. 13

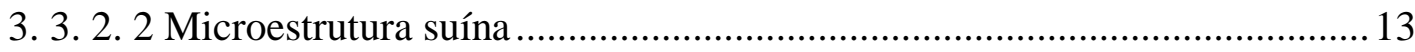

3. 3. 2. 3 Composição óssea................................................................................ 14

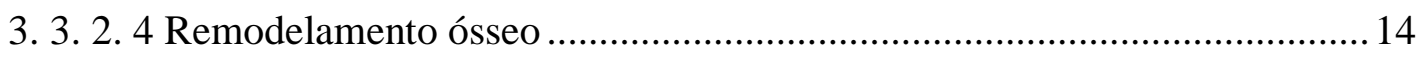

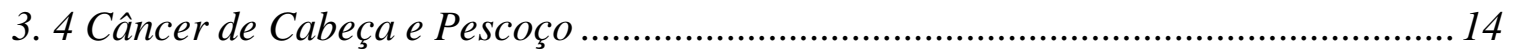

3. 4. 1 Epidemiologia: Prevalência e Incidência ………………............................... 15

3. 4. 2 Terapêutica do câncer: opções de tratamento ..................................................16

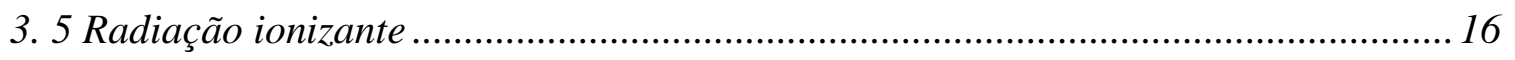

3. 5. 1 Radiação Ionizante e sua interação com a matéria ............................................. 16

3. 5. 1. 1. Transferência Linear de Energia (LET) .................................................. 17

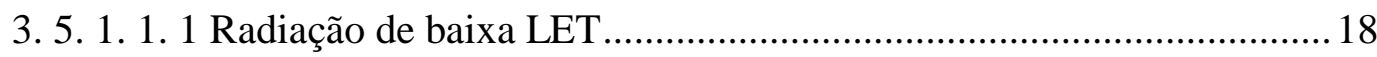

3. 5. 1. 1. 2 Radiação de alta LET …………………………............................. 18

3. 5. 2 Efeitos Biológicos da radiação Ionizante …………………………………….... 19

3. 6 Radioterapia 


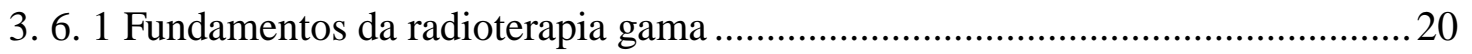

3. 6. 2 Complicações da radioterapia.............................................................. 22

3. 7 Análise por microdureza de superfície $(M D S)$....................................................26

3. 8 Análise por microscopia eletrônica de varredura $(M E V)$......................................22

3. 9 Espectroscopia no Infravermelho por Transformada de Fourier (FTIR). Técnica por

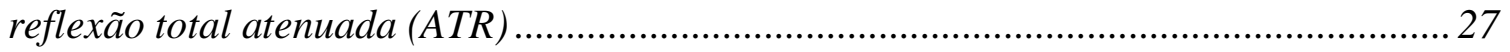

3. 9. 1 Espectroscopia o infravermelho por transformada de Fourier. Generalidades. 27

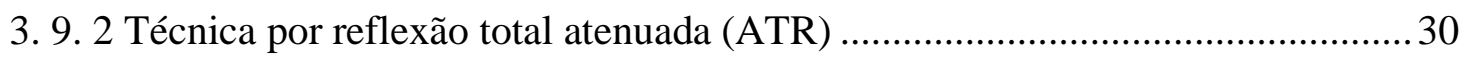

\section{MATERIAIS E MÉTODOS ….................................................................................32}

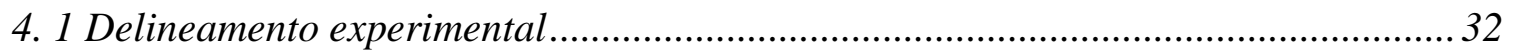

4. 2 Obtenção e preparo das amostras de esmalte e dentina humano .............................. 32

4. 2. 1 Corte e obtenção de blocos de esmalte dentário e dentina radicular ...............32

4. 2. 2 Polimento dos blocos de esmalte dentário e dentina radicular ......................... 37

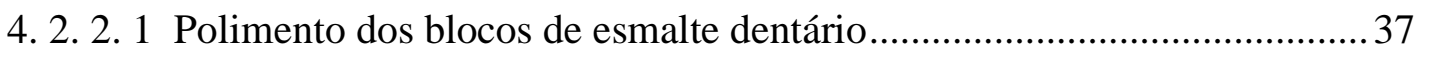

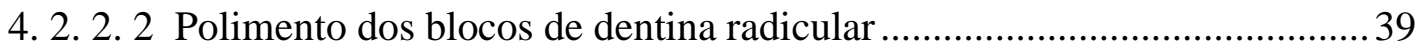

4. 3 Obtenção e preparo de amostras de osso mandibular suíno .....................................39

4. 3. 1 Preparo e polimento de amostras de corpo mandibular suíno .........................42

4. 3. 2 Preparo e polimento de amostras da região do trígono retromolar suíno .........42

4. 4 Análise de Microdureza de Superfície Inicial (Baseline) ...................................... 43

4. 4. 1 Análise de Microdureza de Superfície Inicial (Baseline) para esmalte dentário

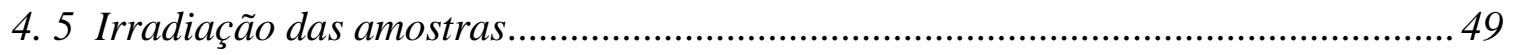

4. 5. 1 Estudo piloto para determinação da taxa de dose ......................................... 49

4. 5. 2 Irradiação das amostras de esmalte dentário ...............................................51

4. 5. 3 Irradiação das amostras de dentina radicular................................................ 51

4. 5. 4 Irradiação das amostras de trígono retromolar ............................................52

4. 5. 5 Irradiação das amostras de corpo mandibular .............................................52

4. 6 Análise de PERCENTUAL de Perda de dureza Superfície ......................................5 52 
4. 7 Análise por microscopia eletrônica de varredura $(M E V)$......................................53

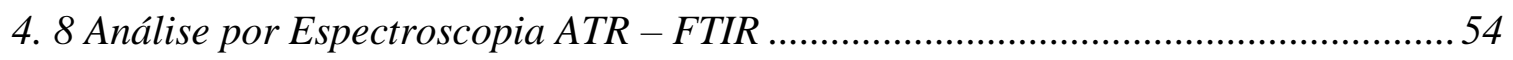

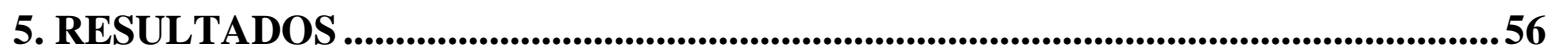

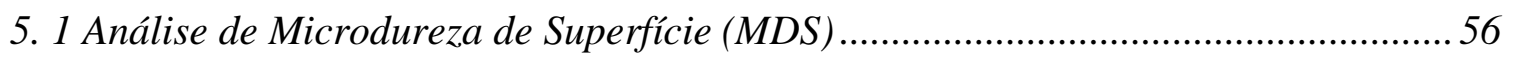

5. 2 Análises na microscopia eletrônica de varredura $(M E V)$......................................68

5. 3 Análises por espectroscopia no infravermelho por transformada de fourier - técnica

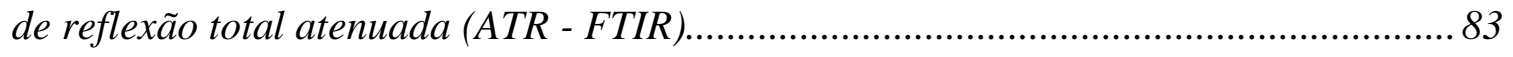

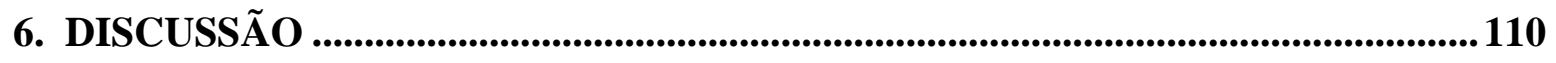

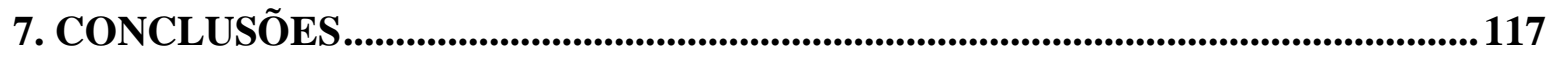

REFERÊNCIAS...............................................................................................................119

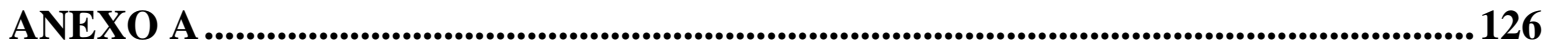




\section{LISTA DE FIGURAS}

Figura 1. Espectro eletromagnético com detalhe na região do infravermelho ……………...28

Figura 2. Interferômetro de Michelson e a Transformada de Fourier ....................................30

Figura 3. Técnica de reflexão total atenuada (ATR) …………………………………....... 31

Figura 4. Cera pegajosa para fixação das coroas e raízes na lâmina de acrílico .................... 34

Figura 5. Coroas fixas a lâmina de acrílico para serem cortadas ...........................................35

Figura 6. Corte manual das coroas dentárias na cortadeira Struers..........................................35

Figura 7. Coroa dentária após o corte manual para obtenção de blocos de esmalte .............36

Figura 8. Raiz dentária após o corte manual fixada a lâmina de acrílico ...............................37

Figura 9. Polimento e ultra-polimento das amostras na politriz com discos de lixa de

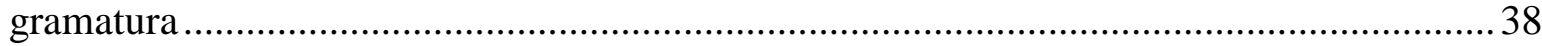

Figura 10. Blocos de esmalte e dentina submetidos a lavagem em ultrassom ......................39

Figura 11. Esqueletização da mandíbula suína - detalhe na região do corpo mandibular ...40

Figura 12. Região do corpo mandibular esquerda suíno delimitada ....................................... 40

Figura 13. Região do trígono retromolar suína esquerda delimitada ...................................... 41

Figura 14. Remoção do bloco inteiro da região do corpo mandibular ..................................... 41

Figura 15. Indentações realizadas no esmalte dentário com uma separação de $100 \mu$ m........44

Figura 16. Dispersão - valores iniciais de microdureza de superfície do esmalte dentário 45

Figura 17. Dispersão - valores iniciais de microdureza de superfície do esmalte dentário

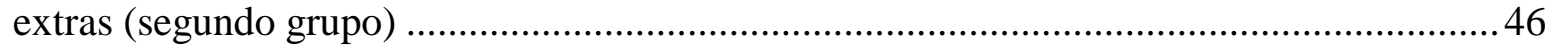

Figura 18. Dispersão - valores iniciais de microdureza de superfície do esmalte dentário extras (terceiro grupo) .46

Figura 19. Dispersão - valores iniciais de microdureza de superfície da dentina radicular.47

Figura 20. Dispersão - valores iniciais de microdureza de superfície da dentina radicular (segundo grupo)

Figura 21. Dispersão - valores iniciais de microdureza de superfície do corpo mandibular48

Figura 22. Dispersão - valores iniciais de microdureza de superfície do trígono retromolar

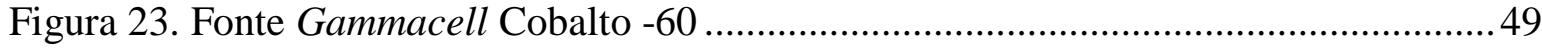


Figura 24. Amostras do estudo acondicionadas nas placas de Petri. 50

Figura 25. Média da microdureza de superfície para determinação da taxa de dose - 2 Gy e 10 Gy 51

Figura 26. Análise das amostras pela técnica de reflexão total atenuada aplicando-se uma força de torque de $130 \mathrm{~N}$ 55 Figura 27. Teste de $t$ de student para análise dos valores da média e erro padrão dos valores de microdureza de superfície inicial e final das amostras em estudo 63

Figura 28. Média das diferenças dos valores de microdureza de superfície inicial e final dos grupos em estudo 68

Figura 29. Amostra de corpo mandibular antes (lado esquerdo) e após a irradiação gama (lado direito) com uma magnificação de 4000x .

Figura 30. Amostra da região do trígono retromolar antes da irradiação gama (lado esquerdo) e após a irradiação gama (lado direito) com uma magnificação de 4000x..........................70

Figura 31. Amostra de esmalte dentário após irradiação gama (500x) .............................71

Figura 32. Amostra de esmalte dentário após irradiação gama (1000x) ........................... 72

Figura 33. Amostra de esmalte dentário após irradiação gama (2000x) ........................... 72

Figura 34. Amostra de esmalte dentário após irradiação gama (4000x) ............................ 73

Figura 35. Amostra de dentina radicular após irradiação gama (500x) ............................. 74

Figura 36. Amostra de dentina radicular após irradiação gama (1000x) ........................... 74

Figura 37. Amostra de dentina radicular após irradiação gama (2000x) ........................... 75

Figura 38. Amostra de dentina radicular após irradiação gama (4000x) ........................... 75

Figura 39. Amostra de corpo mandibular após irradiação gama (500x) …........................76

Figura 40. Amostra de corpo mandibular após irradiação gama (1000x) .......................... 77

Figura 41. Amostra de corpo mandibular após irradiação gama (2000x) ..........................77

Figura 42. Amostra de corpo mandibular após irradiação gama (4000x) ..........................78

Figura 43. Amostra de esmalte dentário após irradiação gama (300x) ............................. 79

Figura 44. Amostra de esmalte dentário após irradiação gama (1000x) ............................79

Figura 45. Amostra de esmalte dentário após irradiação gama (4000x) ........................... 80

Figura 46. Amostra de esmalte dentário após irradiação gama (5000x) ........................... 80

Figura 47. Amostra de dentina radicular após irradiação gama (300x) ............................ 81

Figura 48. Amostra de dentina radicular após irradiação gama (1000x) ........................... 82 
Figura 49. Amostra de dentina radicular após irradiação gama (4000x).......................... 82

Figura 50. Amostra de dentina radicular após irradiação gama (5000x) ........................... 83

Figura 51. Espectroscopia por absorção no infravermelho médio da amostra controle e irradiada de esmalte dentário. .84

Figura 52. Espectroscopia por absorção no infravermelho médio das amostras controle de dentina radicular .86

Figura 53. Espectroscopia por absorção no infravermelho médio das amostras controle e irradiada de dentina radicular .88

Figura 54. Espectroscopia por absorção no infravermelho médio das amostras irradiadas de dentina radicular 89

Figura 55. Espectroscopia por absorção no infravermelho médio das amostras controle de corpo mandibular. 90

Figura 56. Espectroscopia por absorção no infravermelho médio das amostras controle e irradiada de corpo mandibular.... 91 Figura 57. Espectroscopia por absorção no infravermelho médio das amostras controle e irradiada de corpo mandibular .92 Figura 58. Espectroscopia por absorção no infravermelho médio das amostras controle e irradiada de corpo mandibular. 93 Figura 59. Espectroscopia por absorção no infravermelho médio das amostras controle e irradiada de corpo mandibular. .94 Figura 60. Espectroscopia por absorção no infravermelho médio das amostras controle e irradiada de corpo mandibular .95 Figura 61. Espectroscopia por absorção no infravermelho médio das amostras controle e irradiada de corpo mandibular .96 Figura 62. Espectroscopia por absorção no infravermelho médio das amostras controle e irradiada de corpo mandibular .97

Figura 63. Espectroscopia por absorção no infravermelho médio das amostras controle e irradiada de corpo mandibular 98 Figura 64. Espectroscopia por absorção no infravermelho médio das amostras controle e irradiada de corpo mandibular. .99 
Figura 65. Espectroscopia por absorção no infravermelho médio das amostras controle e irradiada de corpo mandibular.... 100 Figura 66. Espectroscopia por absorção no infravermelho médio das amostras controle e irradiada de corpo mandibular 101

Figura 67. Espectroscopia por absorção no infravermelho médio das amostras controle e irradiada de corpo mandibular 102 Figura 68. Espectroscopia por absorção no infravermelho médio das amostras controle da região do trígono retromolar..... 103 Figura 69. Espectroscopia por absorção no infravermelho médio das amostras irradiadas da

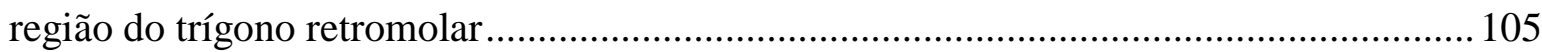
Figura 70. Espectroscopia por absorção no infravermelho médio das amostras irradiadas da região do trígono retromolar. 107 Figura 71. Espectroscopia por absorção no infravermelho médio das amostras irradiadas da região do trígono retromolar. 108 Figura 72. Espectroscopia por absorção no infravermelho médio das amostras irradiadas da região do trígono retromolar..... 109 


\section{LISTA DE TABELAS}

Tabela 1. Média e erro padrão da microdureza de superfície no esmalte dentário 56

Tabela 2. Teste $t$ de student da microdureza de superfície do esmalte dentário 57

Tabela 3. Média e erro padrão da microdureza de superfície da dentina radicular ...............58

Tabela 4. Teste $t$ de student da microdureza da dentina radicular.........................................59

Tabela 5. Média e erro padrão da microdureza de superfície do corpo mandibular .............59

Tabela 6. Teste $t$ de student da microdureza do corpo mandibular .....................................60

Tabela 7. Média e erro padrão da microdureza de superfície do trígono retromolar ............61

Tabela 8. Teste $t$ de student da microdureza de superfície do trígono retromolar ................62

Tabela 9. Análise da diferença da microdureza de superfície dos grupos em estudo ...........64

Tabela 10. Prova de homogeneidade dos grupos analisados através do teste de ANOVA...65

Tabela 11. Teste estatístico Tukey para análise da diferença das médias da microdureza de

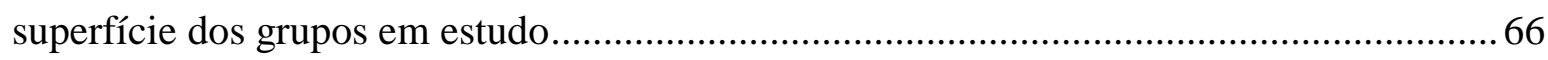




\section{LISTA DE ABREVIATURAS E SIGLAS}

ATR: Attenuated Total Reflection / Reflexão total atenuada

CM: corpo mandibular

cm: unidade de medida centímetros.

FTIR: Fourier transform infrared spectroscopy / Espectroscopia no infravermelho por transformada de Fourier

HPV: Human papiloma virus / Vírus do papiloma humano

IARC: International Agency for Research on Cancer

ICRP: International Commission of Radioprotection / Comissão Internacional de Radioproteção

IMRT: Intensity Modulated Radiotherapy / Radioterapia de intensidade modulada

keV: mil elétron - volt

LET: Linear Energetic Transference / Transferência linear de energia

MDS: Microdureza de superfície

mm: Unidade de medida milímetros

$\mathbf{m N}$ : mili - Newton

MEV: Microscopia eletrônica de varredura

MeV: Mega elétron-volt

OMS: Organização Mundial da Saúde

ORN: Osteorradionecrose

rpm: revoluções por minuto

SMH: Surface microhardness

UAC: União amelocementário 


\section{INTRODUÇÃO}

Com base na documentação da "World cancer report 2014" da "International Agency for Research on Cancer (IARC)”, da Organização Mundial da Saúde (OMS), é inquestionável que o câncer é um problema de saúde pública, especialmente entre os países em desenvolvimento, onde é esperado que, nas próximas décadas, o impacto do câncer na população corresponda a $80 \%$ dos mais de 20 milhões de novos casos estimados para 2025. [1] [2]

A estimativa do câncer para o Brasil, biênio 2016-2017, aponta a ocorrência de 600 mil novos casos de câncer. Excetuando-se o câncer de pele não melanoma (aproximadamente 180 mil casos novos), ocorrerão cerca de 420 mil novos casos de câncer. O perfil epidemiológico observado assemelha-se ao da América Latina e do Caribe, onde os cânceres de próstata (61 mil) em homens e mama (58 mil) em mulheres serão os mais frequentes. Sem contar os casos de câncer de pele não melanoma, os tipos mais frequentes em homens serão próstata $(28,6 \%)$, pulmão $(8,1 \%)$, intestino $(7,8 \%)$, estômago $(6,0 \%)$ e cavidade oral $(5,2 \%)$. Nas mulheres, os cânceres de mama $(28,1 \%)$, intestino $(8,6 \%)$, colo do útero $(7,0$ $\%)$, pulmão $(5,3 \%)$ e estômago (3,7 \%) figurarão entre os principais, [1].

O câncer constituiu-se em um problema de saúde pública, por isso, seu controle e prevenção devem ser priorizados no país. Os cânceres se desenvolvem em múltiplas etapas ao longo do tempo, dessa forma, alguns tipos podem ser evitados pela eliminação da exposição aos fatores determinantes. Se o potencial de malignidade for detectado antes das células tornarem-se malignas, numa fase inicial da doença, o tratamento pode ser muito eficaz e com altas probabilidades de cura [2]. Dentre os tratamentos comumente usados, encontrase a radioterapia, usada amplamente como terapia definitiva ou coadjuvante do procedimento cirúrgico, principalmente, em cânceres da região de cabeça e pescoço. No entanto, altas doses de radioterapia em áreas de amplas dimensões, tais como a cavidade oral, maxilar superior, mandíbula e glândulas salivares podem resultar em efeitos indesejáveis, de aparecimento imediato ou tardio, onde a osteorradionecrose (ORN) é considerada provavelmente a pior, [3].

A ORN é uma das mais severas e sérias complicações orais do tratamento radioterápico do câncer da cabeça e pescoço. Alguns autores, [3], [4] afirmam que, apesar da 
melhora nos cuidados orais realizados antes da radioterapia, a incidência de ORN não diminuiu significativamente nos últimos anos tendo, muito pelo contrário, aumentado entre $1 \%$ a $30 \%$ dos novos casos de osteorradionecrose nesses pacientes.

A ORN é definida como o osso necrótico irradiado exposto, o qual não cicatriza, sobre um período de três meses ou mais, sem a presença de remanescente tumoral ou recorrência do tumor. Esta patologia pode ser encontrada tanto na região do maxilar superior quanto na região mandibular, com uma alta taxa de incidência na região do corpo mandibular e região retromolar documentada nos últimos anos [3], [4]. A sintomatologia clássica da ORN é caracterizada por uma dor intolerável, fratura patológica do osso comprometido, sequestros de osso desvitalizado, processos fistulosos, o que produz incapacidade para os pacientes se alimentarem normalmente. A causa de aparecimento da ORN em um tempo menor que dois anos após a radioterapia deve-se às doses altas de radiação de mais de 70 Gy que receberam os pacientes acometidos por câncer de cabeça e pescoço, e concomitantemente a realização de algum procedimento cirúrgico após o tratamento com a radiação ionizante. A radioterapia reduz a proliferação da medula óssea, do tecido periosteal e das células endoteliais quanto à produção dos componentes da matriz extracelular tais como o colágeno [5], [6], [7], [8].

A patogênese da ORN ainda permanece não esclarecida. Inúmeras teorias baseiamse nos postulados de Marx [3], [4], que afirmam que esta doença deveria ser considerada como um ferimento no osso que não cicatriza por questões metabólicas e distúrbios homeostáticos. Por outro lado, consideram que a ORN resulta de um osso que se torna hipóxico, hipovascular e hipocelular por afecção dos vasos sanguíneos, cujo processo é conhecido como a endarterite, e consequentemente obtém-se um tecido desorganizado e friável, que não cicatriza. Atualmente, aponta-se para uma nova hipótese a respeito da patogênese da ORN, propondo um mecanismo de fibro-atrofia do tecido ósseo induzido pela radiação ionizante, incluindo a formação de radicais livres, disfunção endotelial, inflamação, trombose microvascular, fibrose e remodelação. Como consequência, a progressão da ORN deve-se à ativação e não regulação da atividade fibroblástica que torna o tecido atrofiado dentro da área previamente irradiada, [3].

Dentro dos fatores de risco para o desenvolvimento da ORN, uma das principais consideradas pelos autores [3] e [4] é a radiação ionizante, especificamente, a radioterapia 
gama, cuja taxa, volume e forma de administração, além das diferentes modalidades incluem respectivamente: a dose total, a quantidade de energia por fóton, o campo de irradiação, o fracionamento da dose e a braquiterapia e/ou teleterapia. Embora, tenha-se desenvolvido novas modalidades de radioterapia, tais como Radioterapia Conformacional em 3D, na qual existe uma acurada conformação da dose em torno do volume alvo, a terapia de arco volumétrico modulado (VMAT) possui a mesma capacidade de modulação do IMRT, porém, realizará a entrega da dose nos campos em um arco de até 360 graus de forma simultânea, portanto, isso produzirá um menor investimento de tempo de tratamento quando comparado com o IMRT. Na terapia supracitada, parâmetros como a taxa de dose, velocidade do gantry podem ser variados simultaneamente. Por outro lado, o tratamento no VMAT é realizado pelo volume como um todo, diferente do IMRT, cujo tratamento é realizado por segmento de slices. Finalmente, a Radioterapia de Intensidade Modulada (IMRT), na qual pequenos volumes do maxilar superior e da mandíbula recebem altas doses de radiação, ainda se apresentam casos de ORN nos pacientes submetidos a estas modalidades terapêuticas. Dessa forma, surge a necessidade de mais estudos para o esclarecimento da patogênese da ORN, especificamente, da ação direta da radiação ionizante sobre os tecidos duros da cavidade oral, e posteriormente, estabelecer futuras modalidades no tratamento e prevenção deste efeito deletério da radioterapia.

De acordo com estudo [3], a ORN é improvável de aparecer quando a dose de radiação é menor que 70 Gy; porém, outro estudo, [4], aponta um acréscimo na incidência da ORN em pacientes que receberam doses entre 65 a 70 Gy, tendo como dose média 66 Gy.

Diante da alta incidência da osteorradionecrose que acomete os pacientes submetidos à radioterapia de cabeça e pescoço para o tratamento do câncer, acredita-se que o presente estudo poderá acrescentar dados ainda inéditos na literatura. A osteorradionecrose é uma complicação que diminui a sobrevida do paciente irradiado na medida em que pode causar processos infecciosos, locais e sistêmicos, que se não aumentando a morbidade, diminui consideravelmente a qualidade de vida do paciente irradiado. Adicionalmente a osteorradionecrose pode necessitar de tratamento cirúrgico mutilante. Tendo em vista o supracitado, propõe-se esse estudo para melhor entender o mecanismo de desenvolvimento desta complicação por efeito da radiação ionizante, envolvendo-se todos os tecidos duros da 
cavidade oral, com a finalidade de determinar in vitro, as ações diretas exercidas da radiação gama, como um fator isolado de risco para o desenvolvimento dos efeitos indesejáveis da radioterapia propriamente dita, [3].

Estudo recente, [5], do Laboratório de Biofotônica do Instituto de Pesquisas Energéticas e Nucleares - IPEN (São Paulo - Brasil) mostrou que, isoladamente, o esmalte submetido à radiação ionizante pode não ser mais susceptível à desmineralização do que o esmalte não irradiado, observado in vitro. A dentina radicular, que apresenta maior conteúdo orgânico do que o esmalte, é a mais afetada pela radiação gama em comparação com o esmalte e com a dentina coronária, a qual também apresenta uma maior composição mineral, como demonstrado na literatura, [6] e [8]. No paciente irradiado é sobremaneira importante que haja uma adequação do meio bucal antes do tratamento radioterápico e que se mantenha alimentação e condições de higienização adequadas durante e após o protocolo de terapia com radiação ionizante. Contudo, a dificuldade de higienização da cavidade bucal ocorre nos indivíduos submetidos à radioterapia principalmente pela incidência de mucosite, rigidez muscular ou trismos, e no caso do tecido alveolar, a presença da osteorradionecrose como efeito deletério dose dependente, que pode ocorrer tanto durante, quanto após o tratamento radioterápico.

Ainda que alguns estudos [6], [8] e [9], relatem resultados desfavoráveis nos tecidos da cavidade bucal com maior conteúdo orgânico após tratamento radioterápico; todavia é necessário analisar a quantidade de perda mineral que ocorre nos tecidos duros submetidos à irradiação gama. Considerando que é indispensável investigar estratégias de prevenção que atuem de uma forma mais prolongada nos tecidos irradiados e que estes estudos são inviáveis de realização em um paciente submetido à radioterapia sob o ponto de vista ético, surge a necessidade de desenvolver um estudo in vitro.

A determinação dos efeitos causados pela radiação ionizante, utilizando-se a dose empregada em pacientes acometidos com câncer de cabeça e pescoço, em termos de alteração na composição e microdureza dos tecidos duros fará com que no futuro as possíveis complicações inerentes à radiação sejam diminuídas ou erradicadas, mediante protocolos de fracionamento da dose ou procedimentos preventivos, com dados obtidos em estudos in vitro. 
Desta maneira, este estudo visa determinar, mediante avaliação qualitativa e quantitativa, as alterações na composição e microdureza dos tecidos duros da cavidade bucal submetidos à radiação gama. 


\section{OBJETIVO}

O objetivo geral do presente estudo é avaliar in vitro as alterações morfológicas, variações da microdureza de superfície e alterações bioquímicas no esmalte dentário, dentina radicular e osso mandibular, após a irradiação gama.

A partir deste objetivo geral surgiram os seguintes objetivos específicos mostrados a seguir:

. Avaliar morfologicamente através da microscopia eletrônica de varredura (MEV) os tecidos duros da cavidade bucal antes e após a irradiação gama.

- Avaliar as variações de microdureza de superfície (MDS) dos tecidos duros da cavidade bucal antes e após a irradiação gama.

. Avaliar a composição bioquímica de forma qualitativa pela técnica de reflexão total atenuada na espectroscopia no infravermelho por transformada de Fourier (ATR-FTIR) dos tecidos duros da cavidade bucal antes e após a irradiação gama. 


\section{REVISÃO DA LITERATURA}

A prevalência do câncer no mundo tem aumentado nas últimas décadas ( 29,2 pessoas por 100.000 habitantes na população americana segundo o Instituto Nacional de Câncer dos Estados Unidos) [9], e por conseguinte as complicações subjacentes ao tratamento deste, especificamente nos pacientes acometidos por câncer de cabeça e pescoço. O câncer nesta região pode ser tratado por diferentes métodos amplamente conhecidos, tais como a cirurgia ressectiva, a radioterapia, a quimioterapia ou a combinação destas modalidades de tratamento. A região de cabeça e pescoço, pelo fato de conter estruturas suscetíveis e radiossensíveis, favorece o aparecimento de efeitos indesejáveis no campo de irradiação e nas estruturas circunvizinhas, quando realizada a radioterapia clínica. Uns dos efeitos indesejáveis desta modalidade terapêutica é a destruição parcial ou total dos tecidos duros da cavidade oral despendo do campo envolvido na irradiação ou volume de tecido atingido.

Consequentemente, haverá uma diminuição na qualidade de vida do paciente submetido a períodos prolongados de radioterapia. Inúmeros estudos, [9], [10], [11] e [12], avaliaram os efeitos da radiação ionizante nos tecidos duros humanos e os possíveis fatores contribuintes para o desenvolvimento da sintomatologia e os sinais próprios dos efeitos colaterais produzidos pela irradiação gama. $\mathrm{O}$ protocolo seguido pela maioria dos oncologistas no tratamento do câncer de cabeça e pescoço é o tratamento convencional com dose fracionada como descrito na literatura [9]. O tratamento consiste na aplicação de uma dose total de 65 a $72 \mathrm{~Gy}$, a qual provém de uma fonte de radiação de baixa energia e alto poder de penetração (radiação gama, fonte Co-60 ou com Raios X) com a finalidade da energia atingir as camadas mais profundas dos tecidos envolvidos na lesão maligna. Esta dose é dividida em frações diárias, de aproximadamente 1.8 a 2 Gy por dia. Estas frações são administradas durante um período de 7 semanas, aplicadas 5 dias na semana, [9].

No entanto, apesar de um planejamento exaustivo e cuidadoso por parte do profissional envolvido no tratamento do paciente, a radioterapia pode causar danos nos tecidos normais e as estruturas circunvizinhas envolvidas no campo de irradiação, [10].

As estruturas primárias envolvidas no desenvolvimento dos efeitos indesejáveis são os tecidos dentários, cuja cárie de radiação e a destruição parcial ou total dos dentes, são as consequências mais frequentes da radioterapia nos pacientes acometidos por câncer de 
cabeça e pescoço. Além disso, os estudos têm mostrado que as alterações físicas e biológicas no dente, trarão uma inevitável modificação nas propriedades mecânicas destes, incluindo perda nos valores da microdureza de superfície $(\mathrm{SMH})$, diminuição da resistência à tração e finalmente fratura do tecido, [9] [10] [12].

No que diz respeito ao tecido ósseo, a radioterapia exerce um efeito deletério, tornando-o hipóxico, hipovascular e hipocelular, pelo comprometimento da irrigação sanguínea do parênquima ósseo (processo conhecido como endarterite), o qual produzirá posteriormente a necrose do tecido, e se submetido a algum procedimento cirúrgico, conduzirá à exposição patológica do osso pela incapacidade de cicatrização do leito cirúrgico. Todo esse processo anteriormente descrito chama-se de osteorradionecrose dos maxilares (ORN), apresentada como um dos efeitos indesejáveis de difícil tratamento, [13], [14], [15].

\subsection{ESMALTE DENTÁRIO}

\section{1. 1 Propriedades físico - químicas do esmalte dentário}

O esmalte dentário constitui a porção externa da coroa do dente, protegendo a dentina coronária e radicular, além do tecido pulpar, das agressões externas, sejam de natureza física, físico-química e bacteriana nas atividades diárias realizadas durante os processos fisiológicos de mastigação e deglutição. O esmalte caracteriza-se por ser um tecido não vivo acelular e alto conteúdo mineral. Pelo fato dele ser um tecido acelular, não apresenta capacidade regenerativa, e consequentemente a destruição do tecido acarretará futuras complicações nos tecidos subjacentes, [12], [13].

A estrutura normal do esmalte e a sua configuração geométrica hexagonal, [12] e [13], baseia-se no fato de apresentar um complexo emaranhado de componentes orgânicos e inorgânicos, semelhante a uma organização híbrida com níveis hierárquicos específicos. Os cristais de hidroxiapatita inseridos na malha de colágeno e matriz extracelular encontram-se estreitamente entrelaçados devido à junção gerada pela matriz orgânica, a qual facilita a união destes. Os cristais configuram uma estrutura prismática do esmalte, constituindo uma unidade básica estrutural específica. A bem estabelecida organização dos prismas do esmalte confere as propriedades mecânicas que caracterizam o tecido, tais com a força e dureza superior quando comparados com os outros tecidos mineralizados do corpo humano, [12]. 
O esmalte é principalmente composto de tecido mineral. Entre os principais componentes minerais, destaca-se os cristais de hidroxiapatita, os quais representam a cristalinidade dos cristais de fosfato de cálcio $\left[\mathrm{Ca}_{10}\left(\mathrm{PO}_{4}\right)_{6}(\mathrm{OH})_{2}\right]$. Outros fosfatos de cálcio e fosfatos de magnésio têm sido identificados, associados ou não associados com a apatita tais como a brushite $\left.\left(\mathrm{CaHPO}_{4}\right) \cdot 2 \mathrm{H}_{2} 0\right)$, fosfato octacálcico $\left(\mathrm{Ca}_{8} \mathrm{H}_{2}\left[\mathrm{PO}_{4}\right]_{6} .5 \mathrm{H}_{2} \mathrm{O}\right)$ entre outros cristais amorfos de pirofosfato de magnésio, [12].

O esmalte consiste em uma matriz inorgânica (96\%) e constituintes orgânicos, proteínas e lipídios e água (4\%), os quais ocupam os espaços entre os cristais de hidroxiapatita, [13].

O esmalte forma-se através de um processo de biomineralização, no qual os ameloblastos secretam proteínas tais como a enamelina, amelogenina e ameloblastina, as quais se auto-organizam para formar a matriz extracelular orgânica, a qual se torna o arcabouço na formação da fase inorgânica. Antes e durante o processo de amadurecimento do tecido altamente mineralizado, o componente orgânico sofre uma degradação e redução dos elementos constituintes por meio de enzimas proteolíticas próprias da matriz extracelular, [14], [15]. O tecido remanescente conformará a matriz orgânica do esmalte pós-erupção a qual desenvolve um papel importante no que diz respeito à resistência interna do esmalte, constituída por proteínas insolúveis distribuídas ao redor da superfície dentinária e da junção amelo-dentinária. Estudo recente mostrou que os terceiros molares apresentam uma camada de matriz orgânica que inicia da junção amelo-dentinária e estende-se 200-300 $\mu \mathrm{m}$ até a superfície externa do dente. Dentre os elementos constituintes da matriz orgânica do esmalte foram encontrados o colágeno tipo IV, laminina, nidogenina, proteoglicanos heparin-sulfato e colágeno tipo VII, [15].

O esmalte dentário varia em espessura e densidade sobre a superfície dentária, apresentando maior espessura ao nível das superfícies cortantes ou mastigatórias, sejam bordas incisais ou cúspides, além de uma maior dureza nas superfícies anteriormente mencionadas. Quando a dentição decídua é comparada com a dentição permanente, em termos de espessura e dureza, o primeiro grupo apresentará a metade da espessura e uma menor dureza de superfície que o segundo. A dureza do esmalte é considerada quatro vezes maior do que a da dentina, [13] e [15]. 


\section{1. 2 Análise da ultraestrutura dos tecidos mineralizados}

Os tecidos duros da cavidade bucal apresentam uma composição orgânica e inorgânica semelhante quando trata - se das propriedades físicas, mecânicas e bioquímicas que fazem deles estruturas possuidoras de uma complexa organização estrutural e composicional. Como descrito anteriormente, o esmalte dentário apresenta o maior conteúdo inorgânico dos tecidos duros da cavidade bucal (96\%) sendo os cristais de fosfato e do cálcio os elementos de maior presença no tecido, constituindo a estrutura cristalina e conferindo ao esmalte a dureza característica do tecido pela alta especialização e distribuição desses cristais de hidroxiapatita. A matriz dentinária é similar à matriz do osso mandibular em diferentes aspectos, apresentando um padrão de mineralização do tecido semelhante, embora o tecido ósseo apresente remodelação. O processo de mineralização dos tecidos duros é induzido biologicamente pelo organismo. Os cristais minerais crescem dentro dos espaços celulares e extracelulares, apresentando diferentes orientações no espaço dentro do tecido, [16] e [17].

Por outro lado, apresenta-se um padrão de mineralização mediada pela matriz orgânica, pelo qual o direcionamento dos cristais de hidroxiapatita orientam-se seguindo as fibras de colágeno distribuídas dentro dela. O processo de mineralização do osso e da dentina é mediado pela matriz orgânica. As macromoléculas que compõem a matriz orgânica são responsáveis pela forma e estrutura do comportamento da mineralização. No osso e na dentina, a rede de colágeno tipo I é o principal composto da matriz orgânica. Logo, existe um grupo de proteínas estruturais (glicoproteínas, proteoglicanos), e uma fase de interação entre o conteúdo mineral e uma matriz de proteínas ácidas, e finalmente um grupo de enzimas modificadoras as quais encarregam-se de degradar ou modificar certas proteínas da matriz orgânica visando um autorregulamento do processo de mineralização, [16].

\section{2 DENTINA RADICULAR}

\section{2. 1 Propriedades físico - químicas da dentina}

Diferente do esmalte dentário, a dentina apresenta uma menor quantidade de tecido mineralizado, porém, uma maior quantidade de matriz orgânica e de água. Uma dentina madura é constituída aproximadamente de $70 \%$ de tecido inorgânico, $20 \%$ de matriz orgânica extracelular e $10 \%$ de água. A configuração geométrica dos cristais de hidroxiapatita na dentina difere em tamanho e forma, apresentando-se como placas aplanadas com uma 
dimensão de 60 a $70 \mathrm{~nm}$ de comprimento, 20-30 nm de largura e 3-4 nm de espessura. Os níveis de cálcio e fósforo contido no dente, na região coronária e radicular, oscilam entre os seguintes intervalos: $34-39 \%$ e 16-18\% do peso total respectivamente, além dos inúmeros cátions e ânions que são incorporados na forma catiônica $\left(\mathrm{Ca}^{+2}\right)$ e nos centros aniônicos $(\mathrm{OH}-$ , $\mathrm{PO}_{43-}$ ) na matriz de hidroxiapatita. Ao redor de 40 elementos químicos têm sido reportados como constituintes do tecido dentário, os quais encontram-se distribuídos em toda a estrutura dentária, cujo intervalo oscila entre $\geq 1000$ ppm (tais como Zn, Sr, Fe, Al, B, Ba, Pb, etc) a $\leq 100 \mathrm{ppb}$ (tais como Ni, Li, Ag, As, Se, Nb, Hg, etc.). Toda a composição química descrita anteriormente influenciará as propriedades físico-químicas e o comportamento biológico dos tecidos duros que compõem o dente humano, tal como relacionou-se, em estudo anterior, a presença do elemento Zinco e a dureza do dente, [12].

Estudos recentes, [12], [14] e [15], da análise comparativa entre a composição química do esmalte e da dentina mostram as diferenças essenciais de um tecido para o outro, como descrito no caso da porcentagem de carbono e nitrogênio em maior quantidade na dentina do que no esmalte. Por outro lado, os níveis de magnésio apresentam-se em maior proporção na dentina radicular do que no esmalte dentário, salientando-se o comportamento biológico deste elemento similar ao do Zinco e o Estrôncio, o que explicaria porque a relação $\mathrm{Ca} / \mathrm{P}$ na dentina é menor do que no esmalte, sendo o magnésio o principal substituto do Cálcio diretamente na estrutura dos cristais de apatita, [12] e [15].

A dentina é considerada mais dura do que o tecido ósseo, porém menos dura do que o esmalte dentário devido à composição inorgânica descrita e ao seu conteúdo diminuído de cristais de fosfato de cálcio (quando comparada especificamente com o esmalte), [12] e [16]. Pelo fato da dentina e o esmalte serem duas estruturas não homogêneas e anisotrópicas, além de não obedecerem a Lei de Hooke, as diferenças das propriedades mecânicas baseiam-se nos valores de estresse e tensão aplicados, considerando o módulo de elasticidade de ambos os tecidos, [12], [14] e [15]. Segundo Chun et al. [18], que realizou um estudo padronizado com amostras de esmalte e dentina sob as mesmas condições de experimentação, o esmalte dentário apresentou maior fragilidade diante das forças de tensão e estresse aplicadas nos testes de compressão usados, quando comparado com a dentina, e que o principal papel executado pelo esmalte dentário é de proteção da dentina durante as forças de mastigação 
pela sua alta resistência às forças de desgaste. Por outro lado, a dentina apresentou uma maior resistência às forças da mastigação pelo fato delas serem absorvidas.

\section{3 TECIDO ÓSSEO}

O tecido ósseo, parte do grupo especializado de tecido conjuntivo, apresenta duas propriedades importantes para o bom funcionamento e homeostase humana: além de fornecer a sustentação e a estrutura ao corpo, serve de alavanca para a função motora dos músculos esqueléticos, já que protege os órgãos internos e tem papel fundamental na fisiologia e na dinâmica muscular. O tecido ósseo de forma geral está composto de matriz inorgânica, matriz orgânica e por água. A matriz inorgânica representará a maior proporção composicional (ao redor de 65\%), uma matriz orgânica composta principalmente de fibras de colágeno representando $25 \%$ do peso total do tecido e uma porcentagem de água de aproximadamente $10 \%,[19]$.

\section{3. 1 Matriz orgânica e ligações cruzadas de colágeno}

Sendo o colágeno a proteína de maior presença no tecido ósseo, especificamente no que diz respeito ao osso mandibular, representa aproximadamente $30 \%$ do peso líquido do total de proteínas que conformam as outras regiões do corpo humano. Dentro das funções que esta proteína apresenta, destaca-se a integridade estrutural do tecido propriamente dito e a capacidade de conferir ductilidade a diversos tecidos e órgãos, [16] e [19].

O colágeno tipo I apresenta uma organização estrutural distribuída em fibras que tem origem na microfibrila. Através das interações das moléculas de tropocolágeno, tem-se a formação das microfibrilas, as quais constituem a menor unidade estrutural do tecido conjuntivo. Formadas as microfibrilas, inicia-se o processo de agregação denominado fibrilogênese, para formar fibrilas insolúveis, as quais são mantidas por ligações cruzadas intramoleculares (entre a mesmas unidades de tropocolágeno) e intermoleculares (entre as unidades de tropocolágeno intergrupal) e também por ligações eletrostáticas que lhes conferem estabilidade. Dentro das principais ligações cruzadas de colágeno que são encontradas no osso cortical, principalmente, no osso humano existem as ligações cruzadas enzimáticas imaturas (redutíveis), as ligações cruzadas maduras (não redutíveis) que ligam microfibrilas vizinhas, e ligações cruzadas induzidas por glicação não enzimática (AGES), 
que formam tanto ligações cruzadas de colágeno intermoleculares e interfibrilares, [16] e [19].

A capacidade de resistir à tensão, o colágeno depende da formação de ligações cruzadas covalentes intermoleculares, entre as subunidades de proteínas individuais, pois fornecem resistência ao cisalhamento destas proteínas. É importante salientar que a extensão e o tipo da ligação cruzada variam com a idade do tecido e sua função, já que durante o desenvolvimento do indivíduo, o aumento da tensão nas fibras de colágeno provoca um aumento do número de ligações cruzadas com o objetivo de produzir as propriedades mecânicas ideais para dada função no organismo. Estas ligações são responsáveis pelas propriedades viscoelásticas do tecido ósseo, [16], [19].

\section{3. 2 Características anatômicas da mandíbula suína}

No estudo foram utilizados blocos de corpo mandibular e da região trígono retromolar suíno para análise dos efeitos da radioterapia nessas duas áreas específicas. Os suínos como modelo biológico são usados desde algumas décadas atrás na pesquisa experimental, devido às semelhanças na estrutura interna e o metabolismo ósseo semelhante em ambos os casos, [20]. No homem, áreas de osso haversiano são reabsorvidas mais intensamente do que osso lamelar intersticial, [16], situação que poderia acontecer no porco. Os processos metabólicos e as propriedades funcionais, assim como as densidades e características histológicas ósseas nos suínos apresentam similaridade evidenciada com respeito aos humanos, [20], [21], [22], [23] e [24].

As características apresentadas pelo tecido ósseo suíno são mencionadas a seguir, [25]:

\section{3. 2. 1 Macroestrutura suína}

A respeito da anatomia, morfologia, cicatrização e remodelamento ósseo, o porco apresenta características muito semelhantes no que diz respeito ao osso humano. Porém, o porco apresenta uma rede trabecular mais densa do que os humanos.

\section{3. 2. 2 Microestrutura suína}

Embora o osso suíno apresente uma rede trabecular densa, o porco tem uma estrutura óssea lamelar semelhante à humana. 


\section{3. 2. 3 Composição óssea}

O porco apresenta densidade óssea mineral e concentração de minerais espalhados na redes ósseas semelhantes ao osso humano, [21], [22], [23], [24] , [25].

\section{3. 2. 4 Remodelamento ósseo}

Quando comparados com o remodelamento ósseo humano, os suínos apresentam semelhanças, abrangendo as áreas de osso trabecular e o osso intra-cortical, nas quais se baseiam os princípios de remodelado ósseo. Segundo a literatura [25], as medidas de regeneração óssea encontradas em porcos foram muito semelhantes às dos humanos $(1,2-$ 1,5mm e 1,0-1,5mm por dia respectivamente). O grau de mineralização da cortical óssea após aplicação de fluoreto em porcos em crescimento, usados como grupo controle foi similar aos humanos, [21], [23], [24] e [25].

\section{4 CÂNCER DE CABEÇA E PESCOÇO}

O câncer na região de cabeça e pescoço, faz parte das patologias que levam a óbito se não tratadas, posicionando-se em segundo lugar, dentro dos fatores causais de morte no mundo inteiro. As estruturas que conformam a região de cabeça e pescoço mais afetadas pelo câncer são: a cavidade oral, a orofaringe, a amígdala, a base da língua, a glândula tireoide, e a glândula paratireoide. Segundo a última estimativa do câncer no Brasil pelo Instituto Nacional do Câncer José Alencar Gomes da Silva [1], estimou-se, para o Brasil, no período 2016-2017, 11.140 novos casos de câncer da cavidade oral em homens e 4.350 em mulheres. Isso explica a alta incidência de câncer nos pacientes com fatores de risco associados, tais como o etilismo e o tabagismo, incluindo-se recentemente as infecções pelo Vírus do Papiloma Humano (HPV), especificamente, com respeito às cepas 16 e 18, na população adulta jovem. Este último fator de risco se associa principalmente aos tumores na região da orofaringe, amígdala e base da língua.

O tipo de câncer com maior prevalência na cavidade oral é o carcinoma de células escamosas, cujo diagnóstico é realizado clinicamente e por estudo complementar de imagens, realizando-se na maioria dos casos a análise anatomopatológica da lesão para a obtenção do diagnóstico definitivo, [1], [2], [26], [27], [28] e [29]. 
O sinergismo do etilismo e tabagismo aumentam as chances de aparecimento de neoplasias malignas na região da cavidade oral, apresentando-se um risco de $65 \%$ nos pacientes alcoólatras e fumantes, [1], [26], [28] e [29].

No que diz respeito ao câncer na glândula tireoide, este apresenta-se por fatores genéticos e ambientais, prevalecendo, o maior número de casos por influência ambiental do tipo radiação ionizante à qual o indivíduo é submetido cotidianamente ou pela deficiência nutricional de iodo em determinadas populações. $O$ câncer de tireoide é mais frequente no sexo feminino do que no sexo masculino, e segundo a estimativa do Câncer no Brasil pelo INCA, [1], no ano 2016, estimou-se 1.090 de casos novos de câncer de tireoide para o sexo masculino e 5.870 casos para o sexo feminino, com um risco estimado de 1,08 casos a cada 100 mil homens e 5,70 casos a cada 100 mil mulheres.

\section{4. 1 Epidemiologia: Prevalência e Incidência}

A prevalência do câncer na região de cabeça e pescoço segundo o Instituto de Câncer dos Estados Unidos, no ano de 2014, foi de 29,2 pessoas por 100,000 habitantes. O contínuo crescimento populacional, bem como seu envelhecimento, afetará de forma significativa o impacto do câncer no mundo. Esse impacto recairá principalmente sobre os países de médio e baixo desenvolvimento onde, segundo a IARC/OMS ocorrerá metade dos novos casos e cerca de dois terços dos óbitos por câncer, [2] e [26].

No Brasil, segundo a estimativa do câncer pelo Instituto Nacional do Câncer José Alencar Gomes da Silva, para os anos de 2014 e 2015 foi de aproximadamente 576 mil casos novos de câncer no país [2], quando comparado com a estimativa publicada recentemente pelo Instituto para os anos 2016-2017, apresenta-se um aumento ligeiro da quantidade de casos, a qual aponta a ocorrência de cerca de 600 mil casos novos de câncer no Brasil, [1].

As estruturas da região de cabeça e pescoço com maior número de casos de câncer são a cavidade bucal e a glândula tireoide, as quais apresentam taxas de prevalência e incidência superiores às restantes, segundo a estimativa do câncer, para o biênio 2016-2017, como descritas anteriormente, o que traz consideravelmente à necessidade de estabelecer programas e protocolos de prevenção para assim reduzir o número de morbimortalidade da população acometida, incluindo-se as complicações das modalidades terapêuticas, quando já estabelecido o processo tumoral, dentro do planejamento preventivo e de controle, [1] e [2]. 


\section{4. 2 Terapêutica do câncer: opções de tratamento}

As modalidades terapêuticas para o tratamento do câncer na região de cabeça e pescoço têm mudado nas últimas décadas. A associação entre a radioterapia e a quimioterapia, chamada de "quimo - radiação", em estágio avançado da lesão, tem melhorado o controle local da doença e a taxa de supervivência dos pacientes acometidos, [26]. Porém, esta técnica tem reportado maiores casos de efeitos deletérios e indesejáveis nos tecidos circunvizinhos à lesão, tanto com sintomas de queimação local e gradual, quanto a diminuição da qualidade de vida do paciente, [26], [28] e [29].

No entanto, as técnicas de tratamento convencional do tumor, tais como a cirurgia de remoção da lesão dependendo da classificação e estágio do câncer, assim como as modalidades de radioterapia, ainda são comumente usadas pelos médicos cirurgiões de cabeça e pescoço, oncologistas e pela equipe multidisciplinar envolvida no tratamento do paciente. Novas modalidades de radioterapia têm sido empregadas para melhor controle das complicações nos tecidos sadios circunvizinhos, tais como a Radioterapia de Intensidade Modulada (IMRT), a Radioterapia tridimensional conformacional (3D Conformal Radiation Therapy), usadas como técnicas as quais reduzem o volume de irradiação no campo a ser irradiado, e outras como esquemas de fracionamento de doses como o Hiperfracionamento e o Fracionamento acelerado, ambas estratégias efetivas para melhorar o controle do tumor no espaço e no tempo, [26], [27], [28], [29] e [30].

\section{5 RADIAÇÃO IONIZANTE}

\section{5. 1 Radiação Ionizante e sua interação com a matéria}

A radiação considerada ionizante é aquela capaz de causar a ejeção de elétrons dos orbitais de átomos ou moléculas. O termo radiação ionizante refere-se a toda radiação capaz de gerar íons pelo deslocamento de elétrons de moléculas e átomos de forma direta ou indireta. Os íons e elétrons formados são capazes de gerar radicais livres altamente reativos, que podem desencadear reações químicas com os outros compostos ou mesmo entre si. Tais interações podem levar a alterações nas propriedades físicas e químicas dos materiais, [19], [27].

A radiação ionizante em muitas formas, varia de pouco peso energético, desde raios $\mathrm{X}$ e $\gamma$, a partículas carregadas como emissores alfa naturais, ao mais pesado de alta energia. 
Estas radiações são geralmente classificadas pela ionização específica em termos de transferência de energia linear (LET), definida como a quantidade de energia depositada por unidade de comprimento. As radiações de baixo LET produzem dose respostas curvilíneas para indução de aberração cromossômica. A maior parte dos danos visíveis microscopicamente resultantes da exposição à radiação ionizante pode causar deformações nos cromossomos que são denominadas aberrações, [19].

As radiações eletromagnéticas ionizantes são mais penetrantes percorrendo grandes espessuras antes de sofrer a primeira interação devido ao fato de não apresentarem carga e massa de repouso. A penetração do feixe depende da probabilidade ou seção de choque de interação para cada tipo de evento. O mecanismo pelo qual a radiação eletromagnética ionizante interage com a matéria é uma função complexa da energia da radiação, do número atômico do material ou tecido e da densidade do meio, [19], [27].

A interação ocorre por meio de três mecanismos principais de ionização e deposição de energia: efeito fotoelétrico, efeito Compton e produção de par eletron-positron, lembrando-se que este tipo de radiação percorre distâncias consideráveis antes de transferir parte ou toda sua energia para a matéria, interagindo esporadicamente se comparada com radiações diretamente ionizantes, [19].

O Cobalto-60 é um material amplamente utilizado para irradiação, seja para radioterapia, esterilização de aloenxertos, tratamento de fios metálicos, entre outros. Este é obtido a partir do bombardeamento por nêutrons do Cobalto-59, e apresenta como características meia vida de 5,24 anos, e energia de fóton de 1,17 MeV e 1,33 MeV. É importante lembrar-se que o material biológico é composto principalmente por $\mathrm{C}, \mathrm{H}, \mathrm{O}, \mathrm{N}$, cujos números atômicos são $\mathrm{C}=12, \mathrm{H}=1, \mathrm{O}=16, \mathrm{~N}=141$. Se levarmos em conta a irradiação de material biológico por fótons gama emitidos por Co-60 é possível observar que há a predominância do efeito Compton, [19].

\section{5. 1. 1 Transferência Linear de Energia (LET)}

A Transferência Linear de Energia (LET) define a quantidade de energia média depositada na matéria por unidade de distância percorrida $\left(\mathrm{keV} / \mathrm{e}^{-} \mu \mathrm{m}\right)$. O valor obtido se relaciona diretamente com a massa e a carga de radiação ionizante, [31]. 
Algumas técnicas podem ser usadas, devido à LET é utilizada para observar, comparar e quantificar os efeitos biológicos da radiação ionizante, tais como a análise de aberrações cromossômicas mitóticas, na interfase, método de condensação prematura do cromossomo, FISH. Dentre essas técnicas, a mais vantajosa é a de fluorescência por ser um método de análise mais detalhado, preciso e rápido, [32].

Comparando a radiação de baixa LET com a de alta LET, a alta LET induz uma alta frequência de quebras e rearranjos de cromossomos altamente complexos, [32]. Entretanto, alguns tipos de danos cromossômicos podem conferir a transformação de células em oncogênese e carcinogênese, morte celular e aberrações cromossômicas. O conhecimento preciso dos efeitos biológicos é muito importante para estimar os riscos da radiação ionizante e estabilizar padrões para radioproteção, [32].

\section{5. 1. 1. 1 Radiação de baixa LET}

As radiações consideradas de baixo LET são os raios $X$, radiação $\gamma$, partículas $\beta$. Como descrito previamente, a LET só é definida para radiações constituídas por partículas carregadas. A inclusão dos raios $\mathrm{X}$ e da radiação $\gamma$ se deve ao fato de que após a primeira interação com a matéria, aparecem elétrons por efeito fotoelétrico, por espalhamento Compton ou por formação de pares. Por isso, tais radiações são também denominadas de baixa LET indiretamente. A radiação de baixa LET se adapta ao modelo quadrático ou ao quadrático linear, [33].

\section{5. 1. 1. 2 Radiação de alta LET}

As radiações consideradas de alto LET, como partículas alfa, íons pesados, fragmentos de fissão e nêutrons, são aquelas que possuem um alto poder de ionização e uma alta taxa de transferência de energia num meio material. Para o mesmo valor da dose absorvida, são as que induzem maiores danos biológicos, [33].

Mesmo quando a radiação de alta LET é fracionada, ocasiona grandes danos biológicos devido a maior chance de atingir células mais radiossensíveis. Alta LET pode produzir baixa LET através de elétrons secundários.

A alta LET se adapta ao modelo linear $(\mathrm{Y}=\alpha 0+\alpha \mathrm{D}+\beta \mathrm{D} 2$, onde o Y é a taxa de dose absorvida, $\mathrm{D}$ é a dose, $\alpha$ e $\beta$ são os coeficientes de regressão que determinam a forma e 
a inclinação da curva, sendo $\alpha$ o coeficiente de regressão linear e $\beta$ o coeficiente de regressão quadrática da dose) para indução de fragmentos cromossômicos dicéntricos, [34].

\section{5. 2 Efeitos Biológicos da radiação Ionizante}

A radiação ionizante além de interagir com a matéria, desenvolverá um efeito nas células alvo atingidas. $\mathrm{O}$ fato é que a maioria desses efeitos são prejudiciais e altamente destrutivos, sendo chamados de efeitos deletérios ou indesejáveis segundo o grau de destruição causado nos tecidos alvo. Atualmente, existe uma classificação segundo a Comissão Internacional de Proteção Radiológica (ICRP), [33], classificando-se os efeitos biológicos das radiações ionizantes como efeitos estocásticos e efeitos determinísticos. A exposição às altas doses de radiação em breves intervalos de tempo produzirá efeitos agudos e de curta duração, cada um deles dependendo exclusivamente da dose administrada no tecido alvo. Geralmente, doses altas de radiação tendem a erradicar muitas células, neste caso, células tumorais de rápida divisão, porém, a radiação ionizante, pelo mecanismo inespecífico que apresenta atingirá às células saudáveis, e consequentemente danificará tecidos e órgãos circunvizinhos ao campo de irradiação. Isto pode provocar uma resposta rápida conhecida como a síndrome aguda da radiação. Por outro lado, no caso de exposições às doses baixas de radiação gama, num período de tempo mais extenso, produzir-se-á efeitos crônicos ou de longa duração devido à quantidade de irradiação acumulada. Neste grupo de tecidos alvo submetidos às doses baixas, a radiação tenderá a danificar e modificar as células num longo período, pelo qual apresentar-se-á efeitos não imediatos ou tardios, atingindo principalmente o nível celular, e por consequência, os resultados poderão ser observados depois de passados muitos anos. No caso dos pacientes acometidos por câncer de cabeça e pescoço submetidos à radioterapia gama apresentam-se os dois tipos de efeitos na maioria dos casos analisados na literatura, [3], [4], [7], [27] e [28]. Num primeiro momento, têm-se observado reações teciduais imediatas no tecido mole circunvizinho ao campo de radiação, tais como a mucosite de radiação, a qual é um efeito imediato da radioterapia e apresenta aparecimento precoce, quase nas primeiras semanas após o início do tratamento. Isto demonstra uma reação aguda da mucosa bucal, faríngea e jugal, principalmente atingidas. No entanto, o efeito acumulativo da radiação gama em alguns órgãos e tecidos pertencentes ao campo de irradiação manifestar-se-á de forma crônica, em alguns casos dose dependente nas glândulas salivares (dose maior a 30 Gy), [29], e por outro lado em períodos longos após 
a irradiação tal como a osteorradionecrose mandibular, de aparecimento após três a seis meses da conclusão do tratamento radioterápico, tendo como fator agravante o trauma cirúrgico ou em alguns casos, segundo estudos científicos, [28] e [29], de aparecimento espontâneo após dois anos da radioterapia.

Com respeito à classificação dos efeitos biológicos das radiações ionizantes é necessário estabelecer as diferenças substanciais entre eles para obter-se uma visão esclarecida de quando e por que estes apresentam-se como consequência do tratamento radioterápico. No caso dos efeitos determinísticos estes dependerão principalmente da quantidade de dose administrada no tecido alvo, ou seja, dependem exclusivamente da taxa de dose e dose total recebida pelo órgão ou tecido. Neste caso, a severidade do efeito aumenta com a dose de radiação. No entanto, para o caso dos efeitos estocásticos não existirá um limiar de dose, dito de outro modo, os efeitos não dependerão da taxa de dose ou dose total recebida num período de tempo específico. Consequentemente, os efeitos estocásticos não têm limiar de dose e a severidade nem depende da dose, tendo ocorrência tanto para doses altas quanto para doses baixas, [33].

\section{6 RADIOTERAPIA}

\section{6. 1 Fundamentos da radioterapia gama}

A radioterapia gama faz parte do conjunto das modalidades terapêuticas no tratamento do paciente acometido por câncer de cabeça e pescoço, constituindo uma das primeiras alternativas nos casos de neoplasias invasivas com alta taxa de metástase. A radioterapia gama conforme descrito anteriormente apresenta alto índice de penetração nos tecidos, pelo qual atingirá as células tumorais para sua completa erradicação, porém as células normais serão atingidas na mesma magnitude. A ação inespecífica da radiação gama faz com que apareçam efeitos indesejáveis nos tecidos circunvizinhos, tais como glândulas salivares, mucosa oral, sistema estomagtonático entre outras estruturas de grande importância na região. A dose de radioterapia selecionada para cada paciente dependerá do grau de comprometimento da lesão, a localização e o emprego da radioterapia como única modalidade de tratamento ou em combinação com as alternativas. Atualmente, a dose empregada no que diz respeito à radioterapia convencional gama, a qual é utilizada em diferentes centros de saúde no mundo, oscila entre 50 Gy até 70 Gy, subdividida em frações 
de 1,8 - 2Gy por dia. O fracionamento da dose foi e é utilizado devido à resposta gerada pelos tecidos tumorais e normais, a qual se diferencia no que diz respeito ao reparo do DNA danificado. Além de apresentar a vantagem do reparo do DNA, o fracionamento da dose permitirá uma população maior de novas células entre os intervalos de tempo, especificamente durante o período de descanso, no qual não haverá submissão dos tecidos à irradiação gama, em consequência, reduzir-se-á os efeitos imediatos da radiação, [26], [29].

Outra vantagem apresentada pelo fracionamento da dose é o fato dos tecidos tumorais radiorresistentes serem reoxigenados entre as frações, tornando-os células oxigenadas radiossensíveis, e, portanto, conseguir-se-á uma redução favorável da massa tumoral. Porém, isso aplica-se a tumores malignos de rápida proliferação, tais como os carcinomas epidermoides de língua, de soalho de boca e de glândulas salivares. Apesar de terem se implementado novas modalidades de radioterapia e um planejamento acurado para aplicação das técnicas convencionais, as alterações nos tecidos circunvizinhos ainda têm aparecido. Os efeitos indesejáveis imediatos acometem as estruturas que apresentam um metabolismo acelerado, assim como um rápido recâmbio celular (mucosa oral). Por outro lado, no caso dos tecidos com um recâmbio celular demorado, os efeitos aparecerão posteriormente, inclusive após o término do tratamento radioterápico, [29].

A finalidade de um eficiente tratamento radioterápico é erradicar as células tumorais malignas, porém preservar a maior quantidade das células sadias, quanto à função, morfofisiologia e viabilidade, assim como reduzir ao mínimo os danos ao organismo, [26], [27] e [29].

Novas modalidades de irradiação gama têm surgido nos últimos anos com o intuito de diminuir os efeitos colaterais produzidos pela radioterapia nas estruturas de vizinhança à neoplasia maligna, umas como esquemas de fracionamento diferente do convencional, como o hiperfracionamento da dose e o fracionamento acelerado da dose usada. O outro grupo caracteriza-se pela diminuição do volume de tecido irradiado, tais como a Radioterapia conformacional de três dimensões (3D) e a Radioterapia de Intensidade Modulada (IMRT), além da terapia de arco volumétrico modulado (VMAT).

. No entanto, os efeitos indesejáveis destas modalidades, no caso do primeiro grupo têm aparecido na mucosite oral, apresentando-se uma exacerbação da lesão no local quando 
associada à quimioterapia, e, por outro lado, os efeitos encontrados no segundo grupo, embora tenham sido em menor quantidade e frequência pelo fato deles exercerem uma ação local da maior intensidade de dose, com o menor comprometimento das estruturas circunvizinhas, tem se reportado efeitos indesejáveis imediatos e tardios, [27], [28] e [29].

\section{6. 2 Complicações da radioterapia}

Inúmeras sequelas orais da radioterapia têm aparecido na região de cabeça e pescoço após o tratamento. O envolvimento no campo irradiado, a taxa de dose, o estágio da lesão tumoral, a radiação utilizada e os fatores locais contribuintes são os principais agentes causadores do surgimento destes efeitos indesejáveis. Porém, a radioterapia per se constituise num fator essencial para o desenvolvimento das complicações, pelo mecanismo de ação inespecífico, seja direto ou indireto, que ela exerce sobre os tecidos. As estruturas frequentemente acometidas são a mucosa oral, as glândulas salivares, os dentes, os maxilares e a região da orofaringe. No entanto, outras estruturas circunvizinhas podem ser afetadas como a musculatura Máxilo-facial, a região orbitária, a língua, entre outras.

Dentro das complicações de aparecimento primário, encontra-se a mucosite oral. O fato da mucosa oral apresentar um metabolismo acelerado além de um recâmbio celular rápido, favorece o seu acometimento, [29]. A resposta da mucosa oral frente à radioterapia é o resultado da morte das células epiteliais na fase da mitose, sendo que o ciclo celular das células queratinócitas basais é aproximadamente quatro dias. Por outro lado, a cárie de radiação que acomete os dentes de ambas arcadas se caracteriza por uma rápida progressão da destruição dentária, geralmente após três meses de ter-se iniciado a radioterapia. Os efeitos deletérios da radioterapia sobre o esmalte e a dentina continuam sem esclarecimento. No entanto, o efeito indireto da radiação ionizante, através da radiólise da água, facilita a destruição da matriz orgânica e a dissolução dos cristais de hidroxiapatita tanto em esmalte como na dentina radicular. Porém, existem fatores contribuintes tais como a redução da taxa de fluxo salivar, hábitos do paciente e a dieta de alto conteúdo calórico que intervêm no processo destrutivo, [17], [26] e [27]. Em consequência, a ação direta da radiação gama sobre os tecidos duros, no que diz respeito à perda de minerais, diminuição da dureza de superfície no esmalte e dentina necessitam de uma exaustiva investigação, [17]. A superfície do esmalte é a área de maior acometimento por parte da radiação gama, [27]. 
Estudos recentes [27], [28] e [30] demonstram que a perda das propriedades biomecânicas do esmalte dentário quanto à dentina, são os principais agentes causadores da rápida progressão dos efeitos nas estruturas. A desintegração e consequente perda da estrutura prismática causará micro-abrasões na superfície, tornando-o rugoso pela desmineralização. $\mathrm{O}$ fato da radiação gama alterar o processo odontoblástico com a ine vitável obliteração dos túbulos dentinários, constituirá um tecido com vascularização comprometida e a necrose pela falta de nutrientes será evidente. A microdureza de superfície vê-se gravemente comprometida, e a crescente degeneração celular no espaço amelo-dentinário, conjuntamente com os fenômenos físicos envolvidos na mastigação e a colonização bacteriana fará com que o risco para o desenvolvimento da cárie de radiação seja aumentado, [14], [17] e [26].

Paralelamente ao avanço da cárie de radiação pelos fatores anteriormente mencionados, o acometimento das glândulas salivares pela radiação gama tornar-se-á um dos fatores de alto impacto na qualidade de vida do paciente, com a consequente diminuição da taxa de fluxo salivar devido ao acúmulo de dose superior a 30 Gy, [14], [17], [27], [28], [29], [35], [36], [37] e [38].

A hipossalivação (diminuição da taxa de fluxo salivar) e a xerostomia (sensação de boca seca) subsequente são duas complicações imediatas da radioterapia cujo processo é considerado reversível por alguns autores, [14] e [26], e irreversível por outros, [28] e [29], mas com uma repercussão muita significante na qualidade de vida do paciente, pelo fato de prejudicar a execução normal das funções vitais do ser humano, tais como a mastigação, a deglutição, a fonação, as mudanças no paladar, a dificuldade da fala, o aumento do índice de cárie de radiação e a progressão da mesma, além de contribuir no aparecimento de uma complicação tardia da radioterapia: a osteorradionecrose dos maxilares (ORN), [36], [37] e [38].

A ORN é definida como a exposição de osso irradiado necrótico não cicatrizal após 3 - 6 meses de finalizado o tratamento radioterápico sem evidência de recorrência do tumor, [37]. Esta entidade patológica pode ser encontrada tanto na região do maxilar superior quanto na região mandibular, com uma alta taxa de incidência na região do corpo mandibular e região retromolar documentada nos últimos anos, [39], [40], [41] e [42]. A sintomatologia 
clássica da ORN se caracteriza por uma dor intolerável, fratura patológica do osso comprometido, sequestros de osso desvitalizado e processos fistulosos. Tudo isso produz uma incapacidade para os pacientes acometidos se alimentarem normalmente. A causa de aparecimento da ORN em um tempo menor que dois anos após a radioterapia deve-se às altas doses de radiação de mais de $70 \mathrm{~Gy}$, e concomitantemente a realização de algum procedimento cirúrgico após o tratamento com a radiação ionizante. A radioterapia reduz a proliferação da medula óssea, do tecido periosteal e das células endoteliais quanto à produção dos componentes da matriz extracelular tais como o colágeno, [43].

A patogênese da ORN ainda permanece não esclarecida. Inúmeras teorias baseiamse nos postulados de Marx, [26] e [39], que afirmam que esta doença deveria ser considerada como um ferimento no osso que não cicatriza por questões metabólicas e distúrbios homeostáticos. Outros autores, [44] e [45] consideram que a ORN resulta de um osso que se torna hipóxico, hipovascular e hipocelular por afecção dos vãos sanguíneos, cujo processo é conhecido como a endarterite, e consequentemente obtém-se um tecido desorganizado e friável, que não cicatriza. Atualmente, os autores [46] e [47] apontam uma nova hipótese a respeito da patogênese da ORN, propondo um mecanismo de fibro-atrofia do tecido ósseo induzido pela radiação ionizante, incluindo a formação de radicais livres, disfunção endotelial, inflamação, trombose microvascular, fibrose e remodelação. Como consequência, a progressão da ORN deve-se à ativação e não regulação da atividade fibroblástica que torna o tecido atrofiado dentro da área previamente irradiada. Um último estudo histopatológico e histomorfométrico, [46], realizado em amostras de pacientes submetidos à irradiação gama refere-se o fato de osso mandibular possuir um alto conteúdo de cálcio. Quando comparado com as estruturas circunvizinhas, este tecido absorve de 30 a $40 \%$ a mais de radiação ionizante do que as outras estruturas epiteliais, de tecido mole adjacentes, e este fator tornarse-á contribuinte para os efeitos deletérios que acontecerão na estrutura óssea sob certas condições (fatores locais e sistémicos).

Dentro dos fatores de risco para o desenvolvimento da ORN, uma das principais consideradas pelos autores é a radiação ionizante, cujas diferentes modalidades incluem: a dose total, a quantidade de energia por fóton, a braquiterapia, o campo de irradiação e o fracionamento da dose, [29], [38] e [42]. Embora, tenham-se desenvolvido novas 
modalidades de radioterapia, tais como a Radioterapia de Intensidade Modulada (IMRT), na qual pequenos volumes do maxilar superior e da mandíbula recebem altas doses de radiação, ainda se apresentam casos de ORN nos pacientes submetidos a estas modalidades terapêuticas. Assim, surge a necessidade de mais estudos para o esclarecimento da patogênese da ORN com o objetivo de encontrar futuras modalidades no tratamento e prevenção deste efeito deletério da radioterapia, [26], [39] e [42]. Entre outros fatores de risco para ORN e, considerado um dos principais, independente da radioterapia, está o trauma cirúrgico, especificamente, a exodontia após o tratamento radioterápico, embora a literatura manifeste o aparecimento "espontâneo" da ORN em alguns pacientes sem histórico prévio de remoção dentária. $\mathrm{O}$ abuso do consumo de álcool, assim como de cigarro são claramente identificados como fatores que propiciam a ORN, [26] e [29].

A necessidade de diminuir a taxa de incidência de ORN nos maxilares depende basicamente de encontrar ferramentas preventivas antes dos pacientes serem submetidos à radioterapia. A incidência da ORN é três vezes mais alta em pacientes com dentes do que em pacientes sem dentes, pelo risco de realizarem extração dentária, além de possíveis afecções periodontais, pelo qual é fato que o paciente oncológico que receberá radioterapia deverá ser submetido a um minucioso e intensivo tratamento dentário antes do início do procedimento radioterápico, [29].

Atualmente, existem diversas modalidades no tratamento da ORN, desde o tratamento conservador até ressecções mutilantes por fraturas patológicas da mandíbula, [29], [39] e [42]. A terapia com oxigênio hiperbárico, [35], vem se colocando como uma das alternativas coadjuvantes do tratamento convencional antes e após a realização de algum tipo de procedimento cirúrgico nos maxilares. No caso do tratamento conservador, o uso de medicação baseada em antioxidantes e vitamina E visam uma aceleração no processo de cicatrização do tecido, além de ambos se tornarem potentes agentes antifibróticos. O uso de antibióticos tem o intuito de diminuir a carga bacteriana na ferida, mas não como tratamento definitivo para a cura da lesão. No que diz respeito ao tratamento cirúrgico, os maiores avanços vêm se dando na cirurgia reconstrutiva, com o desenvolvimento de retalhos mio cutâneos ao uso de retalhos livres microvascularizados o que favorece a restauração da 
continuidade da mandíbula quanto o fornecimento do suplemento sanguíneo para o tecido circunvizinho não irradiado, [39] e [41].

\section{7 ANÁLISE POR MICRODUREZA DE SUPERFÍCIE (MDS)}

O teste de microdureza de superfície torna-se um indicador indireto de conteúdo mineral presente na amostra e tem sido relacionado com o início do processo de cárie, podendo ser usado como um indicativo de variações de conteúdo mineral nos processos de mineralização, desmineralização e remineralização [5]. Sua maior vantagem é o controle da variação da dureza na própria amostra, com o qual aumenta-se a confiabilidade dos dados e por conseguinte, diminui o erro experimental. Conceitua-se que o teste é sensível, possível de ser feito em um curto período experimental em superfícies polidas que são mais reativas com respeito aos fenômenos de des-remineralização. O princípio geral do teste de dureza baseia-se na aplicação de uma carga compatível com a resiliência do corpo de prova, a qual produzirá uma deformação quando aplicada. Esta deformação é mensurada e avaliada. Assim, o princípio do teste de dureza Knoop que foi utilizado neste estudo in vitro, baseado em uma carga equivalente a $25 \mathrm{gf}(245 \mathrm{mN})$, compatível com a resiliência da amostra (esmalte, dentina, e osso mandibular) que, quando aplicada perpendicularmente sobre a superfície da amostra, causa uma deformação. Durante todo este experimento in vitro, a carga aplicada sobre as amostras foi constante. A deformação obtida foi mensurada por um software específico que calcula o número de dureza Knoop, de acordo com a carga aplicada de 25 gf e o comprimento da indentação obtida, e posteriormente avaliada. O número de dureza Knoop (KHN) obtido é matematicamente expresso pela equação:

\section{$\mathrm{KHN}=14230 \times \mathrm{C} / \mathrm{I}^{2}$}

Onde C é carga em gf (unidade equivalente de $\mathrm{mN}$, para este estudo determinado pelo software do programa), I é comprimento da indentação em $\mu$ m e 14230 é uma constante, um fator de correção. O resultado desta equação é obtido em (gf) $\mathrm{mN}$. $\mu \mathrm{m}^{-2}$. Esta unidade de grandeza é dividida pela força da gravidade $\left(G=9,80665 \mathrm{~m} . \mathrm{s}^{-2}\right)$ para obtenção do resultado em Mega Pascal (kgf.mm ${ }^{-2}$ ) A carga aplicada foi determinada após o teste de cargas variáveis, compatíveis com a resiliência do esmalte dentário, dentina radicular e osso mandibular, por um mesmo tempo. Foi utilizado para aplicação da carga de 25 gf (245 mN - HK 0,025) para o caso do esmalte, e $10 \mathrm{gf}(98,4 \mathrm{mN}$ - HK 0,01) para o caso da dentina 
radicular e osso mandibular, um penetrador com diamante piramidal que apresenta penetração média 3,5 $\mu \mathrm{m}$ de profundidade para uma indentação de $100 \mu \mathrm{m}$ de comprimento em esmalte, dentina e osso mandibular sadio.

\section{8 ANÁLISE POR MICROSCOPIA ELETRÔNICA DE VARREDURA (MEV)}

A análise por Microscopia Eletrônica de Varredura (MEV) possibilita a geração de uma imagem da superfície do esmalte dentário, dentina radicular e osso mandibular (corpo e região do trígono retromolar), amostras que compõem o presente estudo, por meio da emissão de um feixe de elétrons onde uma parte dos elétrons primários incidentes pode ser retida nos átomos das amostras deslocando simultaneamente os elétrons das órbitas destes átomos.

Os elétrons ejetados pelo feixe de elétrons primários são referidos como elétrons secundários que quando emitidos promovem um desequilíbrio energético, pois os elétrons secundários possuem um nível de energia inferior ao dos elétrons primários. Esta diferença de energia dissipada em forma de Raios X, que é característico em termos de energia e de comprimento de onda $(\lambda)$ para cada elemento exposto ao feixe de elétrons primário; leva em conta que parte da amostra que emite elétrons secundários captados para a geração da imagem, é de superfície e restringe-se à área iluminada pelo feixe e que define a resolução da MEV, [5].

A microscopia eletrônica de varredura forneceu as características de imagem das amostras antes e após a irradiação gama, mostrando-se as mudanças morfológicas e de estrutura de cada grupo submetido à radioterapia, com a vantagem das amostras serem analisadas em diferentes aumentos, com uma maior quantidade de detalhes a serem vistos.

\section{9 ESPECTROSCOPIA NO INFRAVERMELHO POR TRANSFORMADA DE FOURIER (FTIR). TÉCNICA POR REFLEXÃO TOTAL ATENUADA (ATR)}

\section{9. 1 Espectroscopia o infravermelho por transformada de Fourier. Generalidades}

Chama-se de espectroscopia as técnicas de análise que utilizam a interação da radiação eletromagnética com a matéria, na obtenção de informações físicas e químicas sobre o material analisado, [19], [48], [49], [50] e [51]. Na espectroscopia no infravermelho, como o nome sugere, utiliza-se a região no infravermelho do espectro eletromagnético, que corresponde aos comprimentos de onda de $0,78 \mu \mathrm{m}$ a $1000 \mu \mathrm{m}$, como ilustrado na Figura 1 a seguir: 
Figura 1. Espectro eletromagnético com detalhe na região do infravermelho

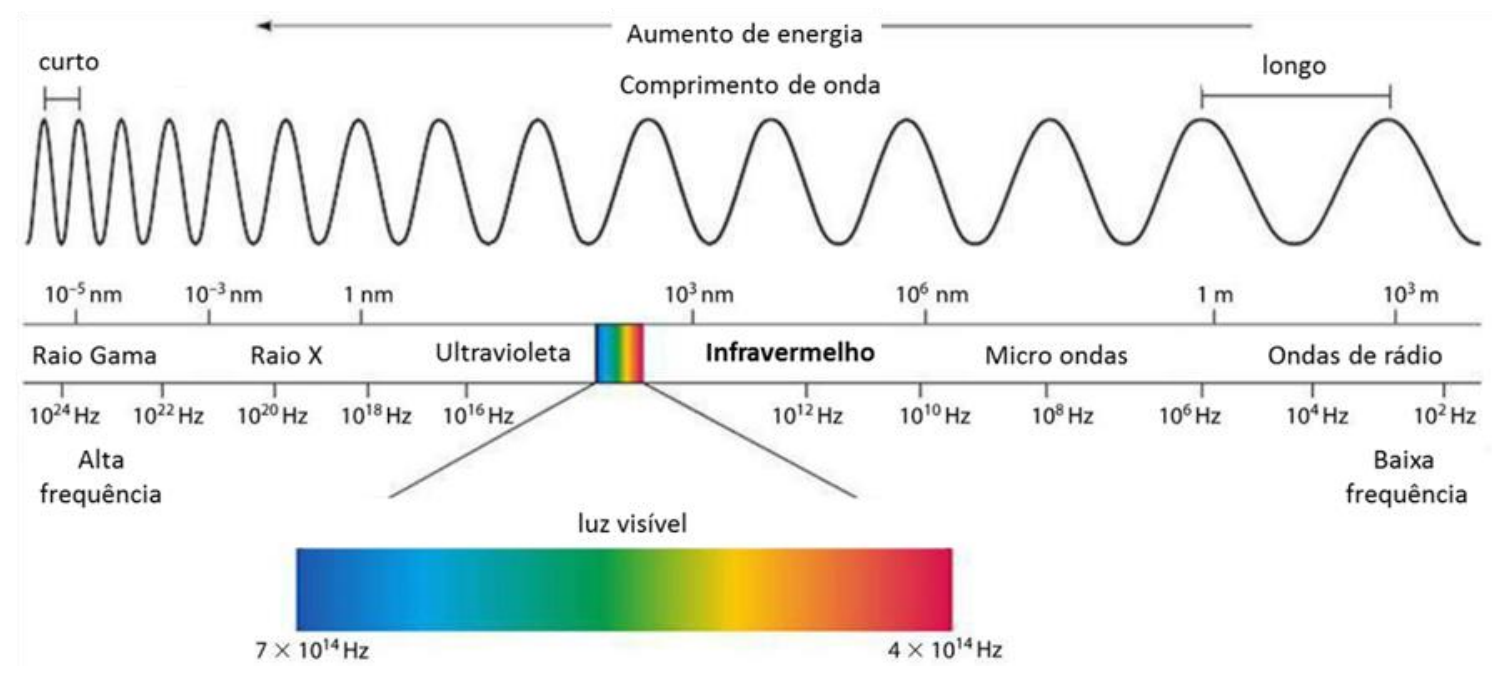

Fonte: Adaptada de [19]

A radiação infravermelha é uma radiação não iônica e não visível, de baixa energia e que não promove transições eletrônicas no material. Por conveniência, nas análises espectroscópicas a grandeza utilizada para representar a radiação no infravermelho é o número de onda, representado pela equação abaixo:

$$
\bar{v}=\frac{1}{\lambda}
$$

Onde $\bar{v}$, corresponde ao número de onda e $\lambda$ ao comprimento de onda. Ele é proporcional à energia da onda eletromagnética e inversamente proporcional a sua frequência, sendo normalmente apresentado na unidade de cm, [19].

Em número de onda, a região do infravermelho corresponde à região espectral de $12.800 \mathrm{~cm}^{-1}$ a $10 \mathrm{~cm}^{-1}$, sendo a sub-região do infravermelho médio $\left(4000 \mathrm{~cm}^{-1} \mathrm{a}^{400} \mathrm{~cm}^{-1}\right)$ a mais comum nas análises espectrais, principalmente a faixa de $4.000 \mathrm{~cm}^{-1}$ a $670 \mathrm{~cm}^{-1}$, devido à grande quantidade de elementos orgânicos que absorvem a radiação eletromagnética nesta região, [19], [48] e [51]. 
A técnica de espectroscopia de infravermelho baseia-se na absorção da radiação eletromagnética pelo material. As moléculas de um material estão em constante movimento, e possuem uma frequência natural de vibração. Quando a movimentação dos átomos da molécula promove uma variação na distribuição de cargas (mudança no momento dipolo), um campo elétrico é criado. Se a radiação incidente no material possui a mesma frequência do campo elétrico gerado, estes interagem e a radiação incidente é absorvida. Portanto, duas condições são necessárias para que ocorra a absorção:

1) A molécula precisa sofrer uma variação do momento dipolo, e

2) A radiação incidente deve ter a mesma frequência de vibração da molécula. Desta forma, conhecendo a frequência da radiação absorvida, é possível identificar o composto responsável pela absorção, [19].

Atualmente, os equipamentos mais utilizados para análises por espectroscopia no infravermelho são os espectrofotômetros com transformada de Fourier, cujo funcionamento se baseia no princípio do interferômetro de Michelson. No interferômetro de Michelson, um feixe de radiação passa por um beamsplitter (um espelho semi-reflexivo) e é dividido em duas partes. Uma parte do feixe é refletida por um espelho fixo e a outra é refletida por um espelho móvel. Quando as partes voltam a se recombinar, há uma diferença entre os caminhos ópticos percorridos, gerando uma diferença de fase entre as ondas eletromagnéticas. Dependendo desta diferença, as interações entre as parcelas do feixe podem ser construtivas ou destrutivas, [19].

A Figura 2, a seguir ilustra o funcionamento dos espectrofotômetros com transformada de Fourier. Neles, a radiação emitida por fonte de radiação infravermelha passa por um interferômetro antes de incidir na amostra. A radiação não absorvida pela amostra incide em um detector, e é gerado um gráfico da intensidade detectada em função da diferença de fase entre as parcelas do feixe, chamado de interferograma. A transformada de Fourier é utilizada para alterar a representação dessa resposta, e transformar o interferograma em um gráfico que representa a quantidade de radiação detectada em função da frequência da radiação, chamado de espectro. 
Figura 2. Interferômetro de Michelson e a Transformada de Fourier

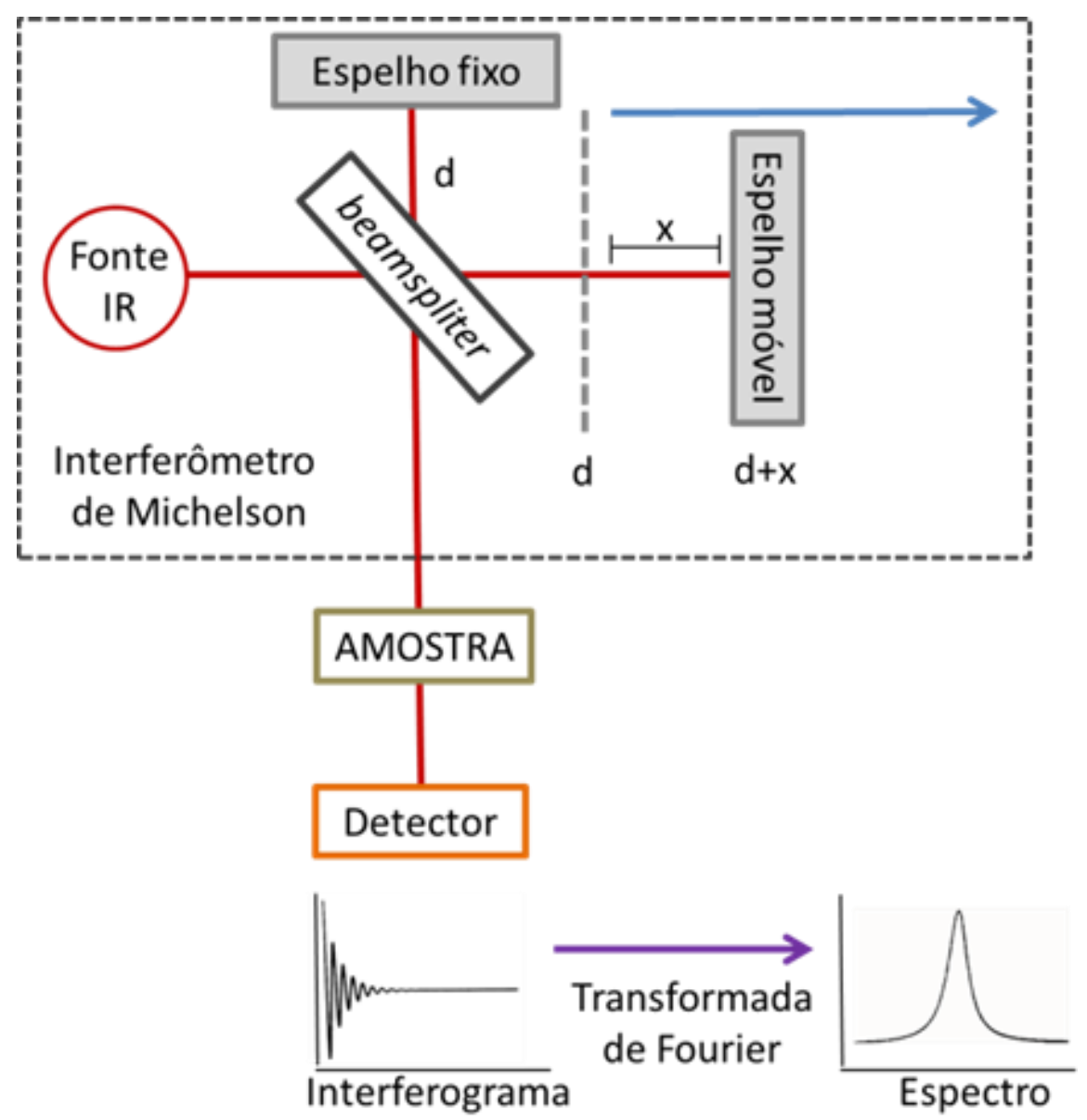

Fonte: Adaptado de [19]

\section{9. 2 Técnica por reflexão total atenuada (ATR)}

Os equipamentos de espectroscopia de infravermelho permitem o uso de diferentes técnicas para a aquisição dos espectros como, por exemplo: por transmissão, reflexão, reflexão total atenuada ou reflexão difusa, além das técnicas associadas à microscopia. Dentre essas, a técnica por reflexão total atenuada (ATR) é bastante utilizada por requerer pouco ou nenhum preparo de amostras, [19].

Basicamente, a técnica de ATR consiste na reflexão de um feixe que incide em um ângulo crítico que passa de um meio mais denso (um cristal) para um meio menos denso (amostra). Nesta condição, uma pequena parcela da radiação incidente (chamada onda evanescente) penetra poucos micrômetros no meio (amostra), podendo ser absorvida. Quando ocorre absorção, o feixe sofre uma atenuação, sendo possível identificar as bandas 
de absorção da amostra e, consequentemente, os seus compostos. O esquema de funcionamento do acessório ATR é representado na Figura 3, ilustrada a seguir:

Figura 3. Técnica de reflexão total atenuada (ATR)

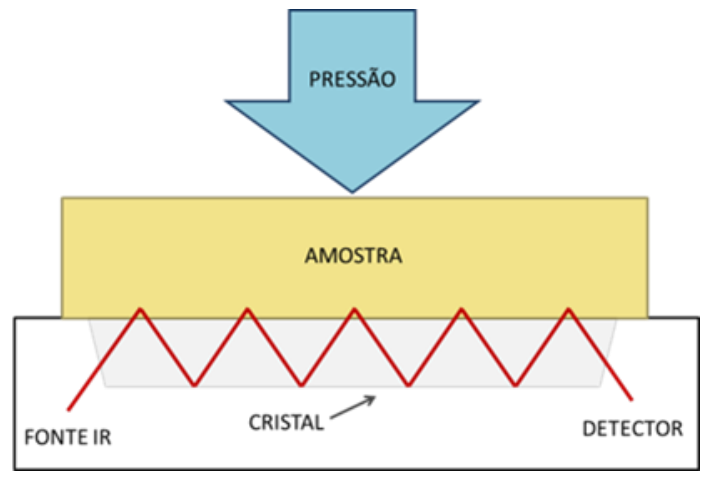

Fonte: Adaptado de [19]

O meio onde o feixe se propaga inicialmente é composto por um material de alto índice de refração, normalmente um cristal de diamante, de seleneto de zinco (ZnSe) ou germânio (Ge). A proporção de feixe refletido varia com o ângulo de incidência, havendo um ângulo crítico onde a reflexão é total, a depender do cristal utilizado como elemento de reflexão, [19] e [48].

A profundidade de penetração da radiação na amostra depende do comprimento de onda da radiação, do ângulo de incidência desta com a amostra, e dos índices de refração do cristal do equipamento e do material analisado. Por exemplo, a profundidade de penetração na faixa do infravermelho médio para o tecido ósseo varia de $0,5 \mu \mathrm{m}$ a $5 \mu \mathrm{m}$, aproximadamente, [19] e [48].

Nos equipamentos ATR-FTIR convencionais, um detector de elemento único é utilizado, e apenas um espectro é obtido em cada medida, representando o espectro médio da região atingida pelo feixe. No imageamento ATR-FTIR, é utilizado um detector FPA (focal plane array) que permite a aquisição simultânea de espectros de uma área da amostra. Ao final da análise, obtém-se uma imagem espectral onde cada pixel da imagem representa um espectro da região correspondente da amostra, e não apenas o espectro médio. O desenvolvimento desta técnica possibilitou analisar uma região específica da amostra de forma simples e rápida, [19]. 


\section{MATERIAIS E MÉTODOS}

\section{1 DELINEAMENTO EXPERIMENTAL}

Este estudo utilizou dentes terceiros molares humanos e mandíbula suína sob aprovação do comitê de ética humana da faculdade de Odontologia da Universidade de São Paulo, USP, Protocolo 43/2008 e pelo comitê de ética no uso de animais, CEUA, do Instituto de Pesquisas Energéticas e Nucleares, Parecer - Projeto No 144/14-CEUA-IPEN/SP.

A partir de 50 terceiros molares humanos hígidos, obtiveram-se blocos de esmalte e dentina radicular após a separação das coroas e das raízes, e blocos de corpo mandibular e região do trígono retromolar após o processo de remoção de tecidos musculares remanescentes, conformando-se quatro grupos de estudo aleatoriamente distribuídos: 1) Grupo de esmalte dentário $=50$ blocos de $3 \mathrm{~mm} \times 3 \mathrm{~mm} \times 1.2 \mathrm{~mm}$, 2) Grupo de dentina radicular $=49$ blocos de $3 \mathrm{~mm} \times 3 \mathrm{~mm} \times 1.2 \mathrm{~mm}$, 3) Grupo de corpo mandibular $=51$ blocos de $3 \mathrm{~mm} \times 3 \mathrm{~mm} \times 1.2 \mathrm{~mm}$ e 4) Grupo da região do trígono retromolar $=49$ blocos de $3 \mathrm{~mm} \times 3 \mathrm{~mm} \times 1.2 \mathrm{~mm}$. Cada grupo foi submetido à análise de microdureza inicial de superfície, e realizou-se 15 indentações por cada amostra, sendo para o caso do esmalte dentário $n=750$ indentações, para o caso da dentina radicular $n=735$ indentações, para $o$ caso do corpo mandibular $\mathrm{n}=765$ indentações e finalmente, para a região do trígono retromolar $\mathrm{n}=735$ indentações, inicialmente consideradas.

4. 2. OBTENÇÃO E PREPARO DAS AMOSTRAS DE ESMALTE E DENTINA HUMANO

\section{2. 1 Corte e obtenção de blocos de esmalte dentário e dentina radicular}

No presente estudo foram selecionados 50 terceiros molares humanos hígidos, correspondente ao grupo populacional deste estudo, provenientes do Banco de dentes da Faculdade de Odontologia da Universidade de São Paulo (USP), os quais foram mantidos em solução de Timol (concentração $1 \mathrm{~g} / \mathrm{L}$ ) por 48 horas e refrigerados a $4^{\circ} \mathrm{C}$. Após a descontaminação inicial dos dentes, estes foram colocados num recipiente com água destilada e deionizada para dar início à separação das coroas e raízes, com a finalidade de obter-se os blocos de esmalte dentário e dentina radicular. Utilizou-se um instrumento de alta rotação com ponta diamantada, realizando-se cortes no nível do limite amelocementário (UAC). Posteriormente, os dentes foram despolpados, ou seja, foi removido todo o tecido 
orgânico remanescente, empregando-se curetas para raspagem e alisamento radicular (Millenium 13 MC e \# 34, reta, \# 35 curva; Millenium 28 bi-ativa de ponta fina, SP, Brasil). Em seguida, estes foram submetidos à limpeza em ultrassom (Lavadora Ultra Sonica Unique - Thomton, Unique Ind. E Com. Ltda., SP, Brasil) por um período de 30 minutos divididos em dois ciclos de 15 minutos para eliminação de restos orgânicos não removidos completamente. Os blocos foram colocados em béqueres de $200 \mathrm{ml}$ de volume, com água destilada e deionizada e posicionados no centro da cuba da lavadora, previamente abastecida com água, e após o primeiro ciclo de lavagem de 15 minutos, foi feito o descarte da água e realizou-se a troca dos recipientes para o início do segundo ciclo de lavagem. Após o segundo ciclo de lavagem, a água dos recipientes foi novamente desprezada, despejou-se finalmente $20 \mathrm{ml}$ de água destilada e os béqueres foram cobertos com papel alumínio e armazenados sob refrigeração a $4{ }^{\circ} \mathrm{C}$ para analises macroscópicas posteriores.

Logo depois, os blocos foram submetidos à profilaxia e raspagem rigorosa para eliminar os detritos e o biofilme mineralizado remanescentes na superfície coronária e radicular. Utilizou-se pasta profilática composta de pedra pomes e água destilada, de uso odontológico. Para a profilaxia foi utilizado um micromotor e um contra ângulo de utilidade odontológica (Dabi Atlante, SP, Brasil), e em seguida, as raízes foram submetidas à raspagem com curetas para alisamento radicular. Em seguida, as coroas e raízes, foram submetidas à limpeza em ultrassom, por um período de 30 minutos divididos em dois ciclos de 15 minutos como descrito anteriormente, para eliminação de possíveis tecidos orgânicos ou da pasta de pedra pomes utilizada na profilaxia. Posteriormente, os blocos foram secos com papel absorvente durante 5 minutos à temperatura ambiente para avaliação macroscópica mediante lupa estereoscópica.

Para a análise macroscópica dos blocos obtidos, estabeleceram-se critérios de inclusão e exclusão, os quais incluíram as coroas e raízes isentas de defeitos visíveis (trincas, processos cariosos inicias, manchas, linhas de fratura, esmalte esburacado, região cervical comprometida) e manchas brancas de ambos tecidos duros, excluindo-se os blocos que não cumpriram com as características supracitadas.

No que diz respeito ao corte e obtenção dos blocos de esmalte dentário e dentina radicular, realizou-se a fixação das coroas e raízes selecionadas em uma lâmina de acrílico 
de aproximadamente $4 \mathrm{~cm}$ de largura por $5 \mathrm{~cm}$ de diâmetro, na qual utilizou-se cera pegajosa amarela como apresentado na Figura 4, colocada em uma lamparina e aquecida até o derretimento da cera que foi transportada à lâmina de acrílico mediante um gotejador de metal. Foi colocado um pingo de cera para o posicionamento de uma das bordas da coroa, paralelo à borda lateral da lâmina e por último realizou-se a fixação das laterais da coroa. Com a coroa fixada à lâmina, tal como ilustrado na Figura 5, efetuou-se o um corte em sentido transversal e horizontal na cortadeira manual (IsoMet. Buehler, SP, Brasil), com disco diamantado de alumínio de grão fino (Struers, SP, Brasil). A coroa sujeita ao corte foi posicionada no ângulo desejado em relação ao braço maior do equipamento e direcionou-se o disco para o seccionamento da coroa em sentido transversal, com uma distância de $3 \mathrm{~mm}$ x $3 \mathrm{~mm}$ apresentado na Figura 6, aproximadamente, entre corte e corte até atingir a parte basal da coroa, obtendo-se os blocos de esmalte como visualizado na Figura 7.

Figura 4. Cera pegajosa para fixação das coroas e raízes na lâmina de acrílico

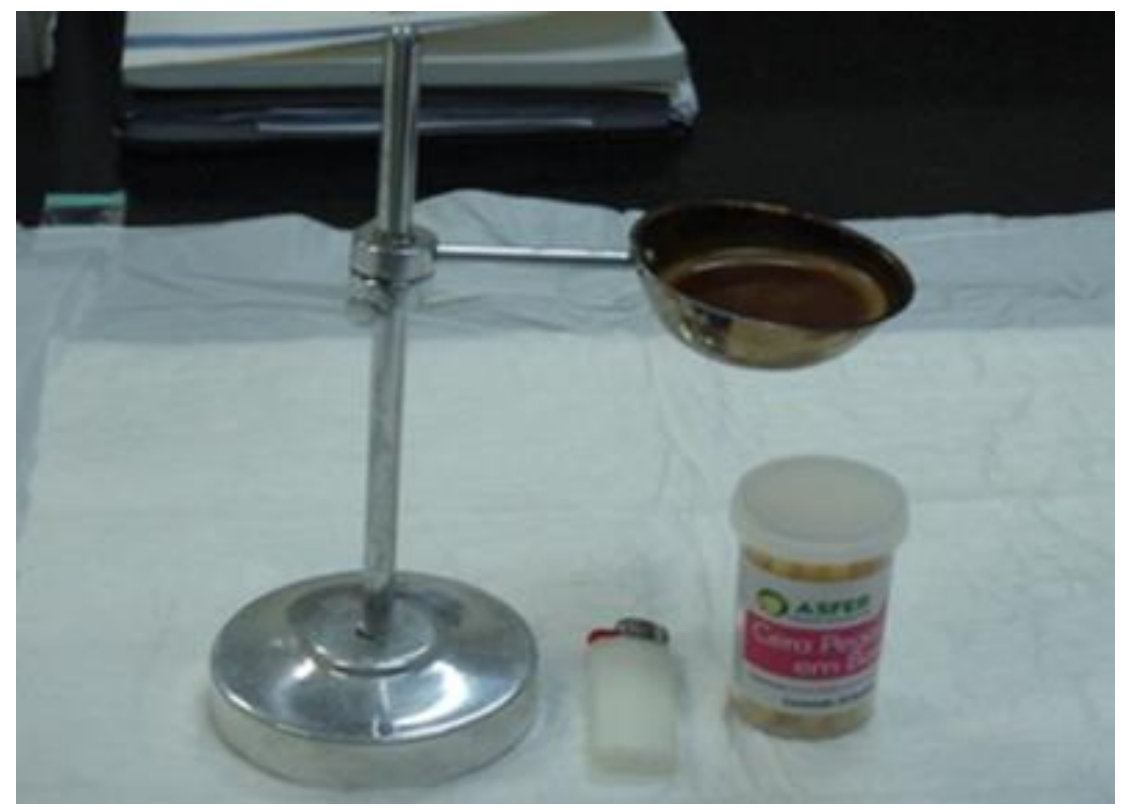

Fonte: Autor 
Figura 5. Coroas fixas a lâmina de acrílico para serem cortadas

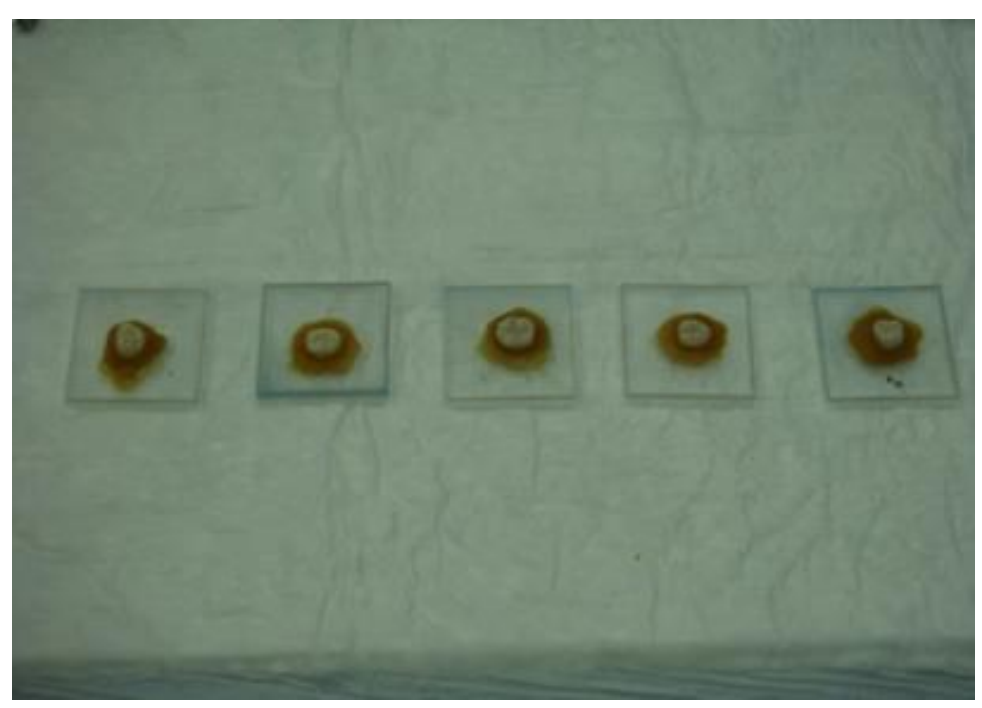

Fonte: Autor

Figura 6. Corte manual das coroas dentárias na cortadeira Struers

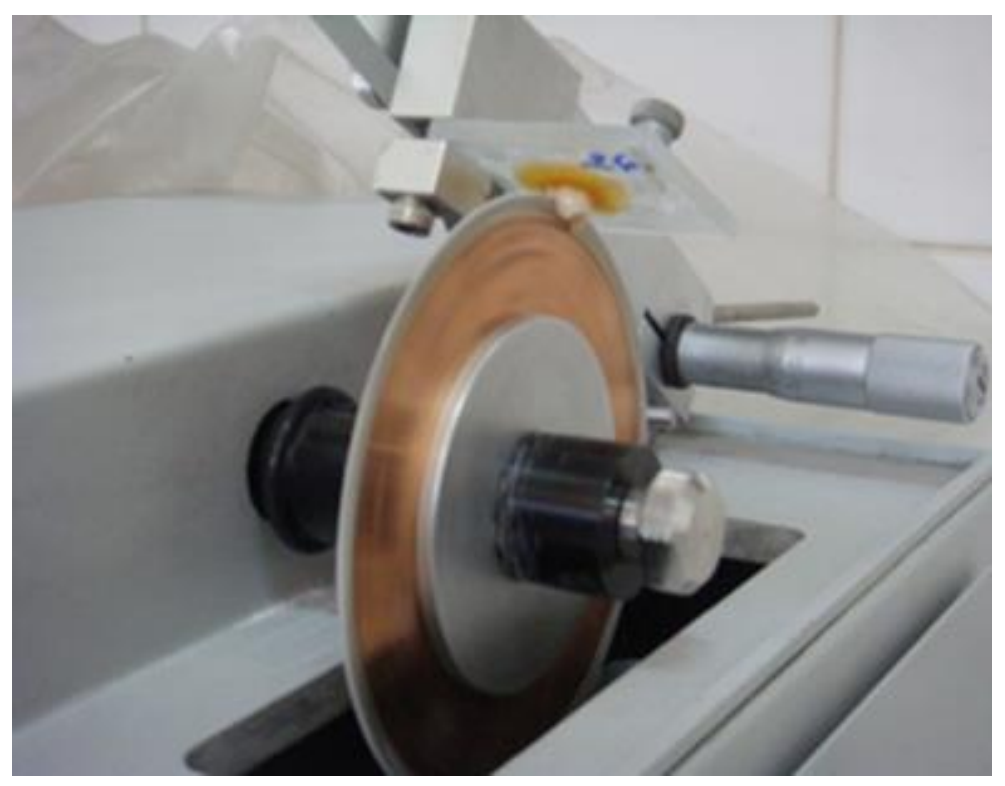

Fonte: Autor 
Figura 7. Coroa dentária após o corte manual para obtenção de blocos de esmalte

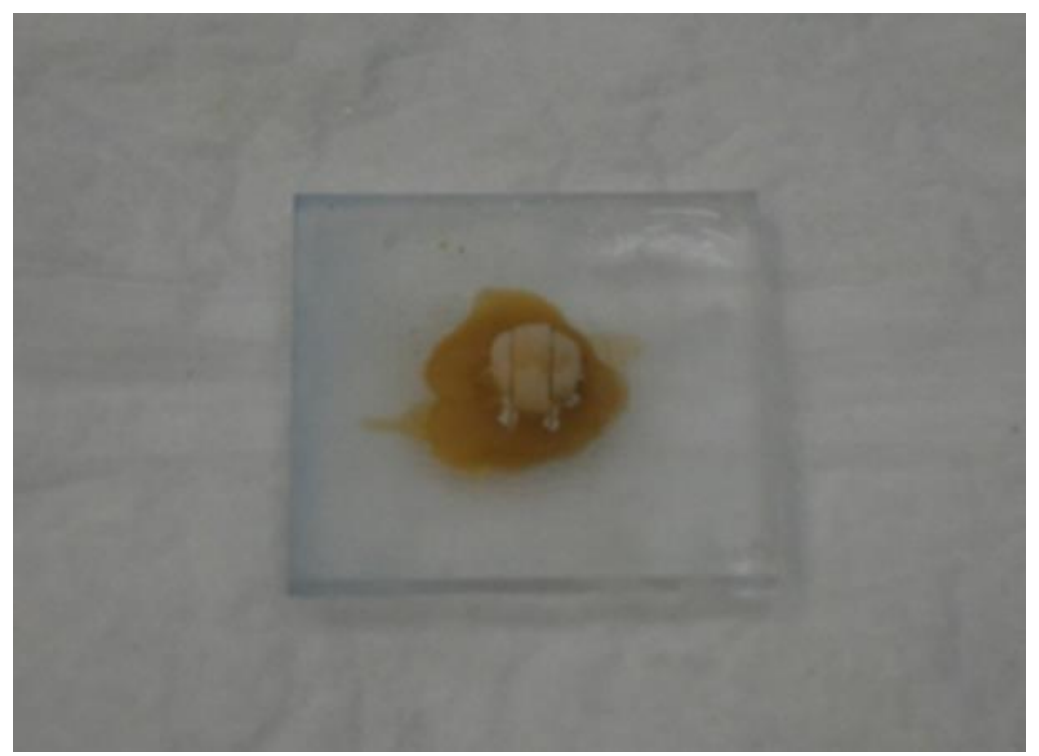

Fonte: Autor

Para o corte das raízes, foi realizado o procedimento semelhante ao do esmalte descrito anteriormente, com fixação prévia da raiz e subdividindo-se em três linhas imaginárias à face frontal em direção transversal e horizontal. Obtiveram-se, os blocos de dentina radicular de aproximadamente $3 \mathrm{~mm}$ x $3 \mathrm{~mm}$, como apresentado na Figura 8. 
Figura 8. Raiz dentária após o corte manual fixada a lâmina de acrílico

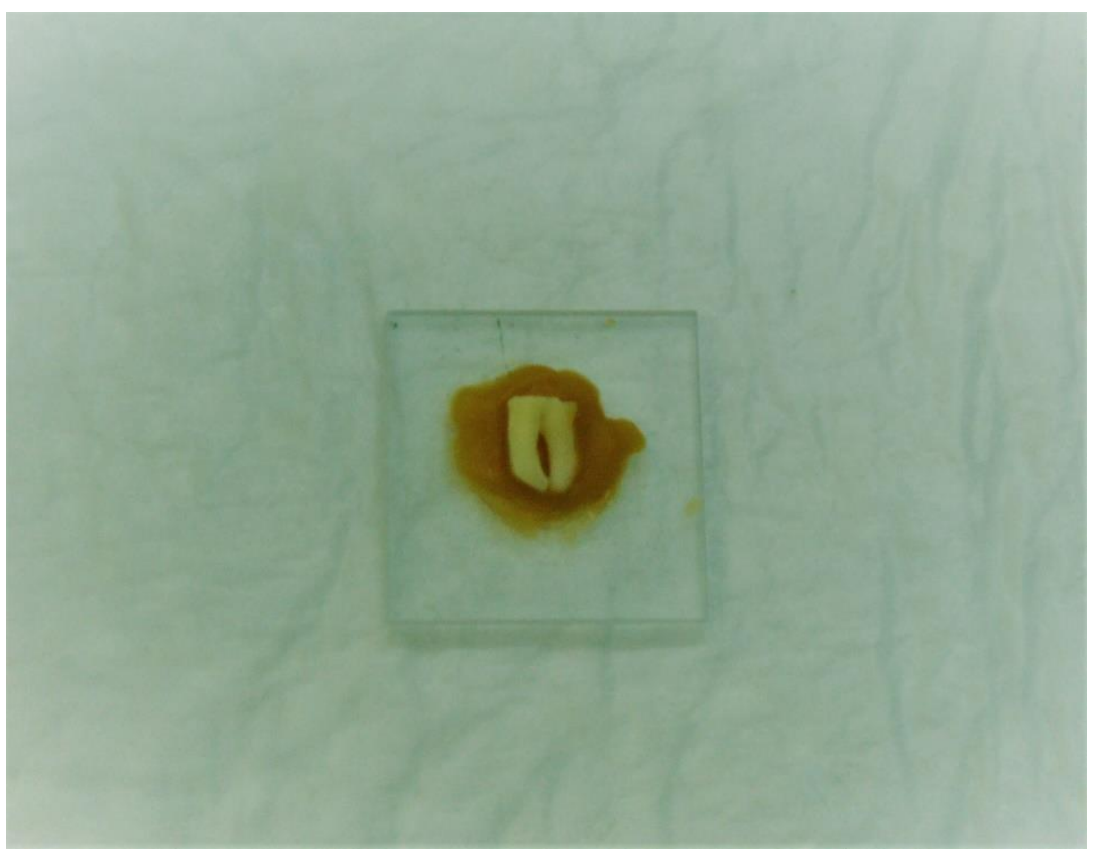

Fonte: Autor

\section{2. 2 Polimento dos blocos de esmalte dentário e dentina radicular}

\section{2. 2. 1 Polimento dos blocos de esmalte dentário}

Uma vez obtidos os blocos de esmalte e dentina radicular, estes foram submetidos ao polimento manual para análise da microdureza inicial de superfície. Os blocos foram montados na lâmina de acrílico, fixados com cera pegajosa como descrito anteriormente. Para o caso dos blocos de esmalte dentário, foi fixada à lâmina de acrílico, em um primeiro momento, a superfície de esmalte para assim fazer o polimento da dentina remanescente e obter-se uma superfície plana e totalmente paralela às arestas da lâmina em uso. Em seguida, os blocos foram polidos na politriz (Figura 9), para o qual foram usados discos de lixa de gramatura de diferentes grãos: iniciou-se com um disco de 400-800 de grão grosso sob refrigeração durante 15 segundos com uma velocidade de giro de $100 \mathrm{rpm}$, e a seguir, um disco de 600-1200 sob refrigeração durante 10 segundos com uma velocidade de giro de 100rpm. Posteriormente, foram usados os discos de 2500 durante 10 segundos e com uma velocidade de 100rpm, e para finalizar usou-se um disco de grão fino de 4000 durante o tempo e a velocidade anteriormente descritos. O polimento foi completado com o ultra polimento dos blocos com solução diamantada de $1 \mu \mathrm{m}$ (Buehler, SP, Brasil) sem 
refrigeração, despejada no disco de feltro e executada com uma velocidade de 300rpm durante 1 minuto.

Figura 9. Polimento e ultra-polimento das amostras na politriz com discos de lixa de gramatura

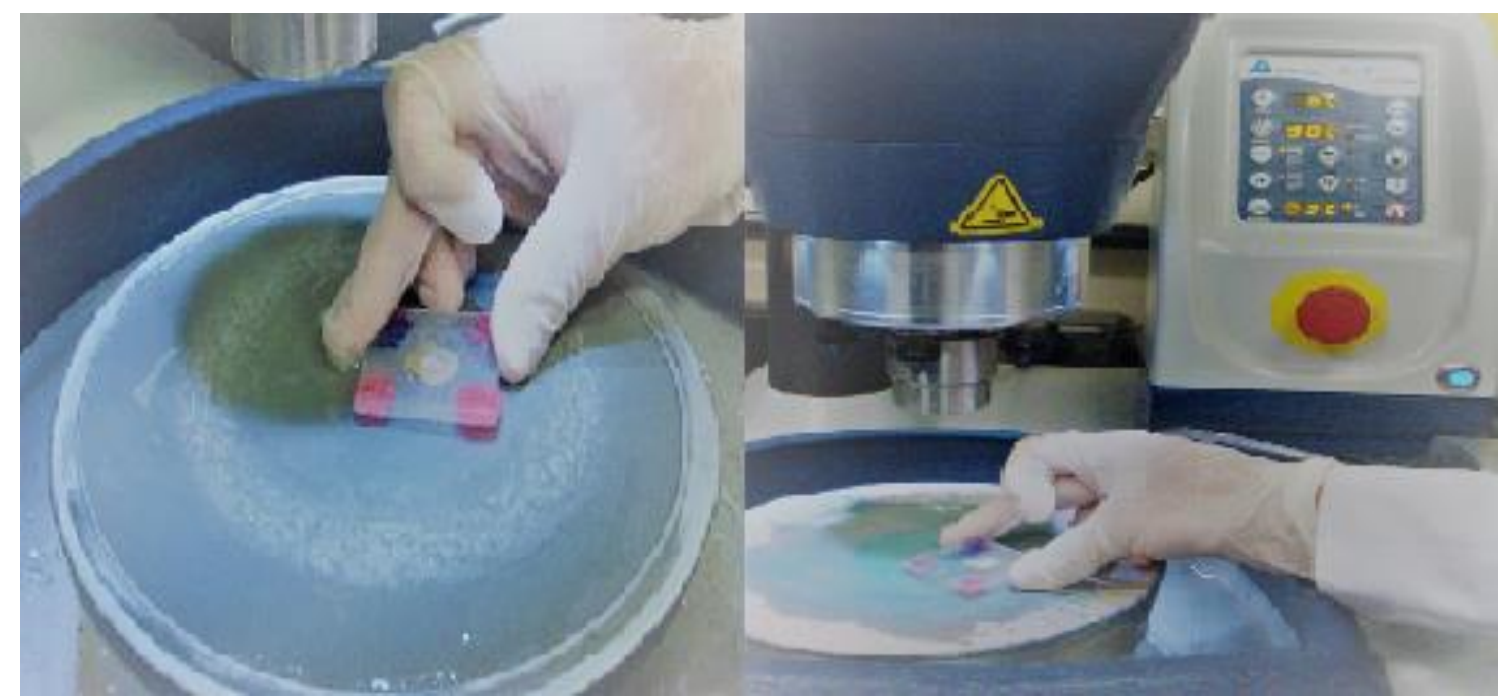

Fonte: Autor

O procedimento descrito anteriormente foi realizado para a superfície de esmalte dentário, o qual foi virado para cima e consequentemente a dentina previamente polida foi virada para lâmina de acrílico, fixando-a com cera pegajosa nas bordas laterais com a precaução de evitar contato entre a cera e o bloco.

Ao finalizar o polimento dos blocos, as amostras obtidas de esmalte dentário foram submetidas à lavagem em ultrassom como apresentado na Figura 10 durante 40 minutos subdivididos em 5 ciclos de 8 minutos cada, e desprezou-se a água destilada em cada ciclo. Os béqueres com amostras foram cheios de água destilada e deionizada e armazenados durante 24 horas para posterior fixação das amostras na lâmina de acrílico. 
Figura 10. Blocos de esmalte e dentina submetidos a lavagem em ultrassom

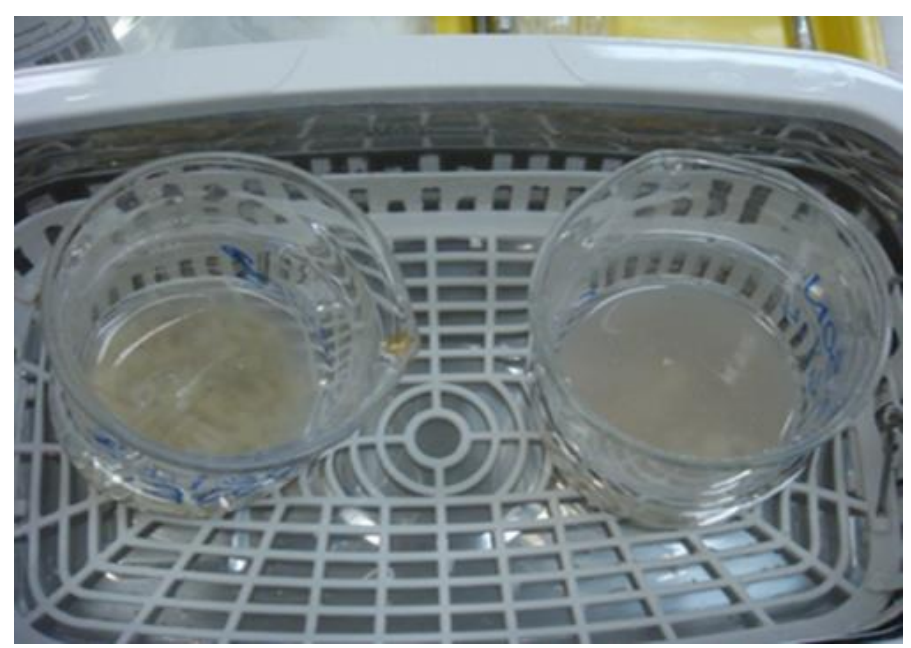

Fonte: Autor

\section{2. 2. 2 Polimento dos blocos de dentina radicular}

Os blocos de dentina radicular foram polidos com a metodologia empregada para os blocos de esmalte como descrito anteriormente. Ambas as superfícies da dentina radicular foram polidas até obter-se uma superfície plana de aproximadamente $3 \mathrm{~mm} \times 3 \mathrm{~mm}$ x 1,2mm, realizado na politriz e com os discos de lixa de gramatura de 400-800, 600-1200, 2500 e 4000 conforme protocolo executado anteriormente. Finalmente, estes foram submetidos ao ultrapolimento com solução diamantada de $1 \mu \mathrm{m}$, sem refrigeração, com uma velocidade de 300rpm durante 1 minuto.

Ao finalizar o polimento dos blocos, as amostras obtidas de dentina radicular foram submetidas à lavagem em ultrassom, como descrito para o caso anterior.

\section{3 OBTENÇÃO E PREPARO DE AMOSTRAS DE OSSO MANDIBULAR SUÍNO}

Foram selecionadas mandíbulas suínas de $15 \mathrm{~cm}$ de comprimento por $10 \mathrm{~cm}$ de largura, fornecidas pela Frigorífica Raia (Carapicuíba, SP, Brasil). As mandíbulas foram lavadas com água destilada e deionizada em abundância, em seguida, foram armazenadas em recipientes estéreis no freezer, para manutenção dos tecidos biológicos não removidos enquanto não utilizados, sob temperatura de $-88^{\circ} \mathrm{C}$.

Foi realizado o processo de remoção do tecido mole remanescente no laboratório de preparo de amostras biológicas do Centro de Lasers e Aplicações (CLA), como ilustrado na 
Figura 11, Figura 12 e Figura 13, tais como fáscias musculares, músculos e ligamentos pertencentes à estrutura tecidual do animal. Usou-se uma lâmina de bisturi $\mathrm{N}^{\circ} 15$, um cabo de bisturi $\mathrm{N}^{\circ}$ 3, além de uma pinça sem dentes para o prensado do tecido e exérese definitiva. Foi realizada uma abundante lavagem com água destilada e deionizada após remoção completa dos tecidos remanescentes, obtendo-se uma peça cirúrgica limpa e homogênea superficialmente. Após cada procedimento cirúrgico, as mandíbulas foram envolvidas em um envelope plástico de fechamento hermético e armazenadas sob temperatura de $-88^{\circ} \mathrm{C}$ para preservação das peças cirúrgicas quando não utilizadas.

Figura 11. Esqueletização da mandíbula suína - detalhe na região do corpo mandibular

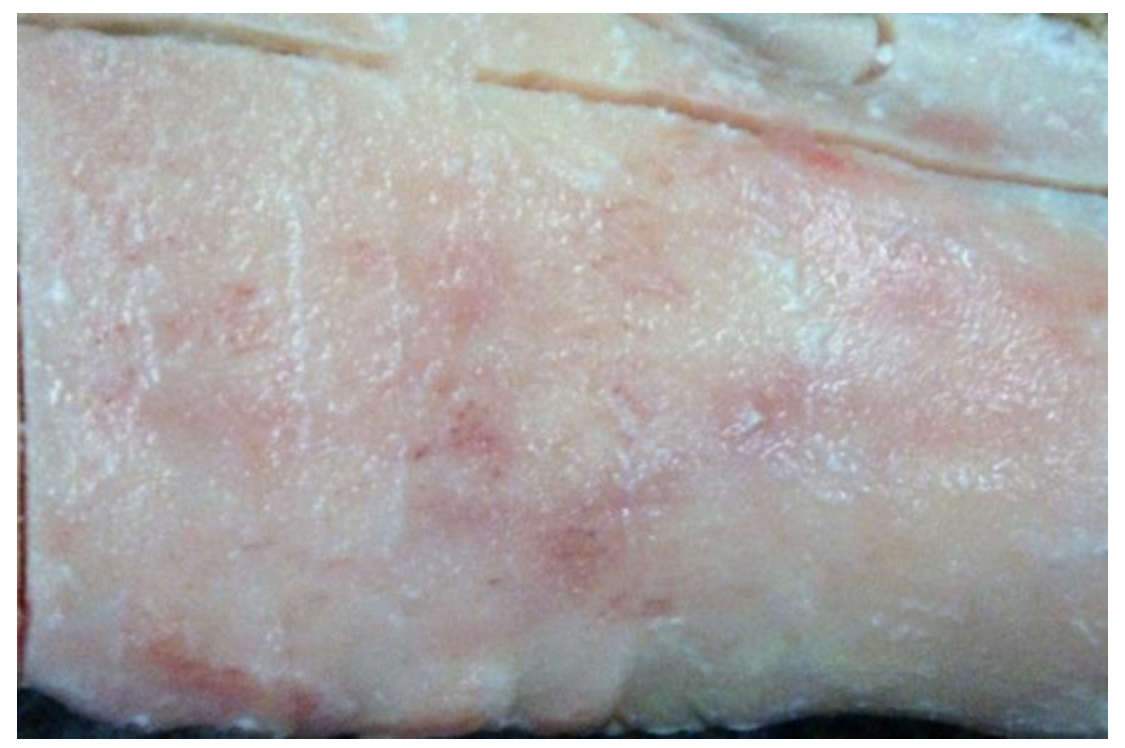

Fonte: Autor

Figura 12. Região do corpo mandibular esquerda suíno delimitada

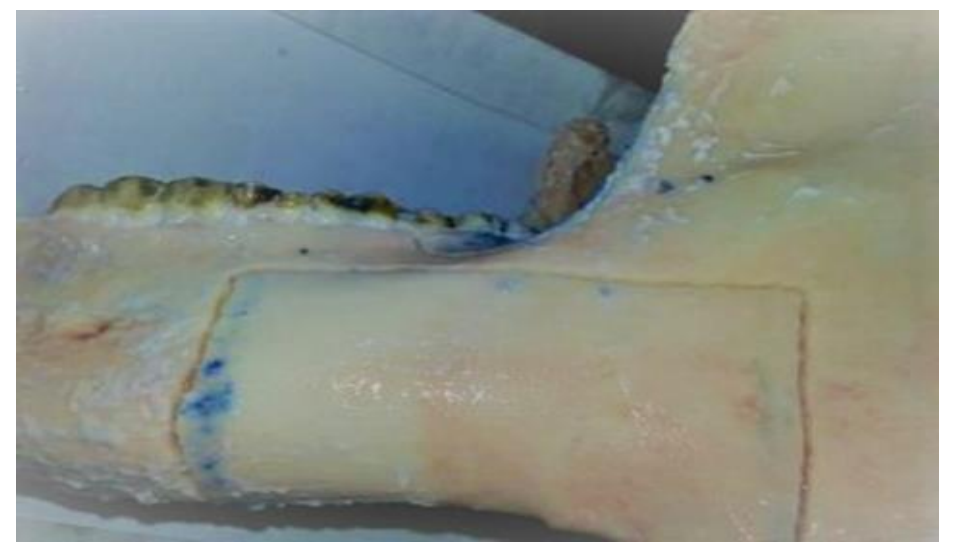

Fonte: Autor 
Figura 13. Região do trígono retromolar suína esquerda delimitada

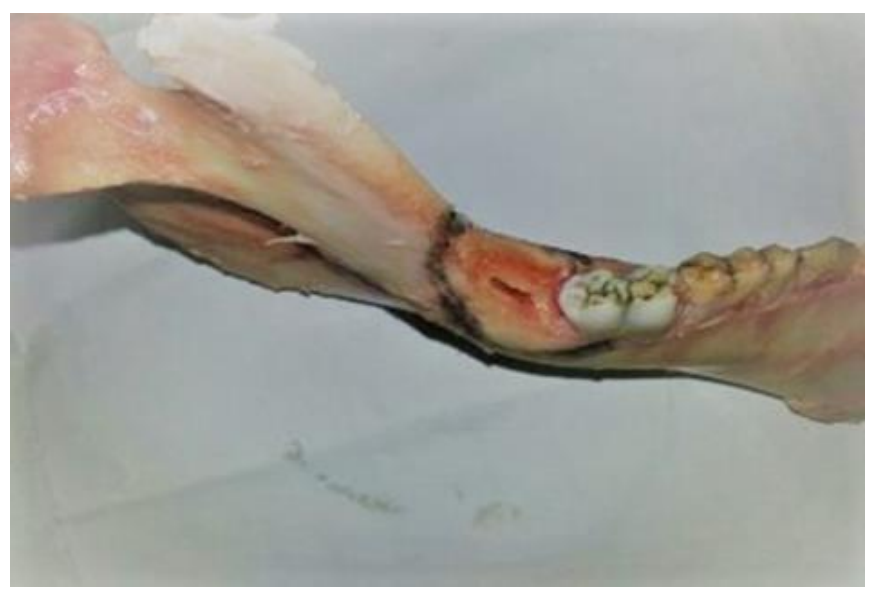

Fonte : Autor

As peças cirúrgicas foram subdivididas em duas metades para melhor manejo das hemimandibulas de ambos os lados, direito e esquerdo. Foram obtidos os blocos da região do corpo mandibular, como visualizado na Figura 14 através de corte manual com micromotor de baixa rotação, com disco diamantado de alumínio e disco de carburundum metálico, pelo qual foi realizada a irrigação abundante com água destilada até a obtenção do bloco final, para assim diminuir o efeito térmico após o corte. No caso dos blocos da região do trígono retromolar, foi efetivado o procedimento anteriormente descrito.

Figura 14. Remoção do bloco inteiro da região do corpo mandibular

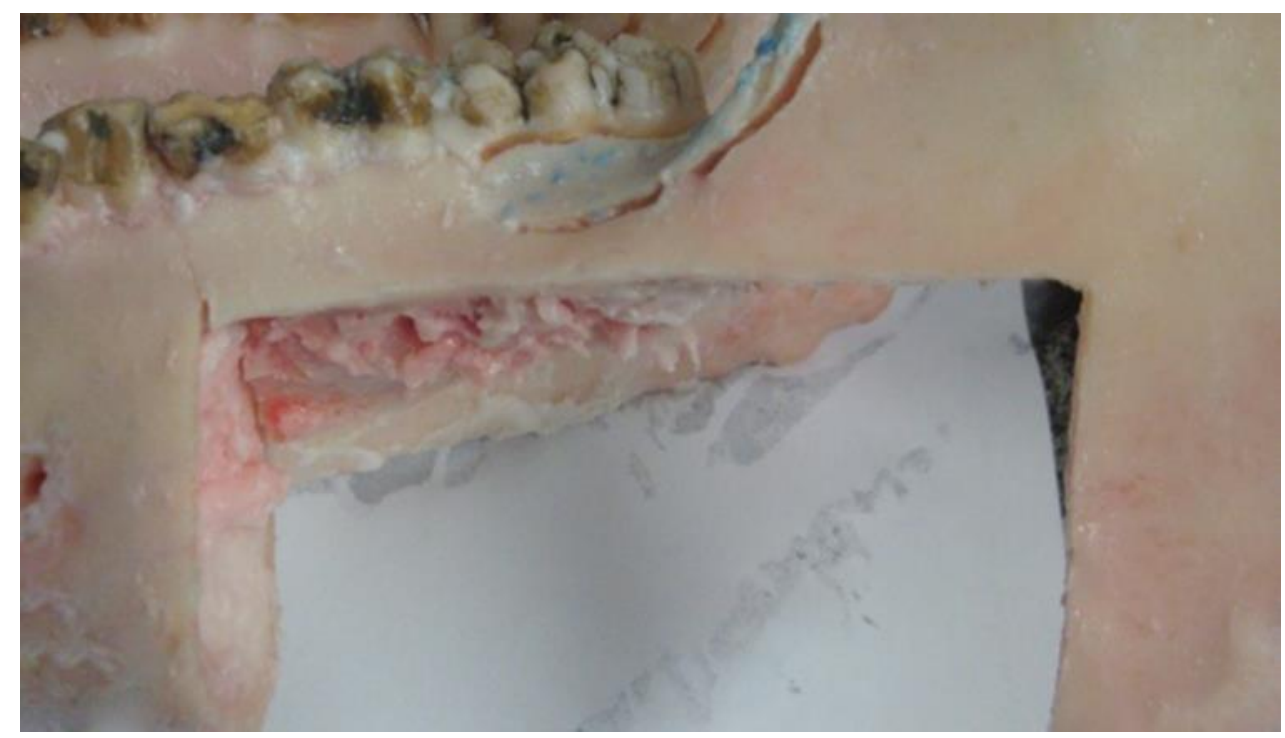

Fonte: Autor 
Após a obtenção dos blocos de ambos os grupos, estes foram submetidos à lavagem em ultrassom para remoção dos tecidos orgânicos remanescentes. Colocaram-se os blocos em béqueres estéreis com água destilada e deionizada, seguindo-se a lavagem durante 5 ciclos de 8 minutos cada, e finalmente os blocos não analisados e/ou utilizados no mesmo foram armazenados sob temperatura de $-88^{\circ} \mathrm{C}$ até serem posteriormente analisados.

\section{3. 1 Preparo e polimento de amostras de corpo mandibular suíno}

Os blocos de corpo mandibular suíno obtidos foram submetidos ao corte vertical e transversal na cortadeira manual (IsoMet, Buehler, SP, Brasil) para obtenção de blocos menores de $3 \mathrm{~mm}$ x 3mm x 1,2mm. Foram fixados à lâmina de acrílico com cera pegajosa, com as bordas do osso paralelas às arestas da lâmina. O corte iniciou-se na borda mais externa do bloco e continuou-se até a borda interna, tendo-se como distanciamento entre corte e corte $3 \mathrm{~mm}$ x $3 \mathrm{~mm}$. Em seguida, os blocos obtidos foram submetidos à lavagem em ultrassom durante dois ciclos de 15 minutos.

Posteriormente, os blocos foram fixados novamente à lâmina de acrílico com cera pegajosa e foi realizado o polimento na politriz. Iniciou-se o polimento com discos de lixa de gramatura de 800, 1200, 2500 e 4000, durante 15 segundos para o primeiro caso e 10 segundos para os subsequentes discos, com uma velocidade de 100rpm. Finalmente, se realizou o ultra polimento com solução diamantada de $1 \mu \mathrm{m}$ e disco de feltro seco, sem refrigeração, com uma velocidade de 300rpm durante 1 minuto. Consequentemente, foi realizada a lavagem em ultrassom para remoção dos restos da solução diamantada. Os blocos foram armazenados em um béquer com água destilada e deionizada, tampado hermeticamente e sob refrigeração de $4{ }^{\circ} \mathrm{C}$ durante 24 horas.

\section{3. 2 Preparo e polimento de amostras da região do trígono retromolar suíno}

Os blocos da região do trígono retromolar obtidos, foram submetidos ao corte vertical e transversal na cortadeira manual (Isomet, Buehler, SP, Brasil) para obtenção de blocos menores de aproximadamente $3 \mathrm{~mm}$ x $3 \mathrm{~mm}$ x 1,2 $\mathrm{mm}$. Realizou-se previamente um desgaste e adaptação dos blocos, devido à anatomia irregular da região e com a finalidade de facilitar a fixação deste na lâmina de acrílico. O desgaste foi feito com discos diamantados de alumínio sob refrigeração montados no motor de baixa rotação de uso odontológico. Logo depois, foi realizada a fixação dos blocos na lâmina de acrílico com cera pegajosa quente. Os 
blocos foram submetidos ao corte vertical e transversal, com distanciamento entre os cortes de $3 \mathrm{~mm}$ x $3 \mathrm{~mm}$ x 1,2 mm com uso de disco diamantado de alumínio de grão fino (Struers, SP, Brasil) e sob refrigeração manual com água destilada e deionizada. Posteriormente, estes foram submetidos à lavagem em ultrassom como anteriormente descrito. Em seguida, foi feito o polimento manual na politriz de ambas as superfícies, segundo o protocolo descrito anteriormente. Logo depois, as amostras foram armazenadas em béquer estéril com água destilada e deionizada, tampado hermeticamente, durante 24 horas. Finalmente, as amostras foram fixadas na lâmina de acrílico para análise da microdureza de superfície inicial (baseline).

\section{4 ANÁLISE DE MICRODUREZA DE SUPERFÍCIE INICIAL (BASELINE)}

As amostras obtidas dos quatro grupos de estudo e fixadas na lâmina de acrílico foram submetidas à análise de microdureza de superfície inicial (MDS) com a finalidade de obterse uma avaliação quantitativa da homogeneidade nas superfícies das amostras após o polimento. Assim, para análise de MDS (Baseline), foi utilizado um microdurômetro (Shimadzu HMV-200, Japão) provido de indentador Knoop que foi programado para aplicar uma carga de $245,2 \mathrm{mN}(\mathrm{HK} 0,025)$ durante 10 segundos (s) para o caso das amostras de esmalte dentário, e uma carga de 98,4 mN (HK0,01) durante 15 segundos (s) para as amostras de dentina radicular, trígono retromolar e corpo mandibular.

Os valores de referência para seleção das amostras e a análise da microdureza de superfície inicial em cada tecido foram determinados segundo o descrito a literatura, [14], [15] e [17], como descritos a seguir:

. Esmalte dentário: 274 - 338,35 (Valor Knoop - unidade: kgf.mm²)

. Dentina radicular: 41,4 - 70 (Valor Knoop - unidade: kgf.mm²)

. Cuerpo mandibular: 15,4 - 20,2 (Valor Knoop - unidade: kgf.mm²)

. Região do trígono retromolar: 9,7 - 15,07 (Valor Knoop - unidade: kgf.mm²)

\section{4. 1 Análise de Microdureza de Superfície Inicial (Baseline) para esmalte dentário}

Cada amostra de esmalte dentário foi posicionada no microdurômetro e mantida sem movimentação durante toda a análise. Para cada amostra foram realizadas 15 indentações subdivididas em três filas de 5 indentações, as quais foram separadas em distâncias de 100 
$\mu \mathrm{m}$ a partir de uma borda inicial, a qual foi previamente selecionada e marcada para futura referência. A distância entre fila e fila foi de $200 \mu \mathrm{m}$ como ilustrada na Figura 15:

Figura 15. Indentações realizadas no esmalte dentário com uma separação de 100 $\mu \mathrm{m}$

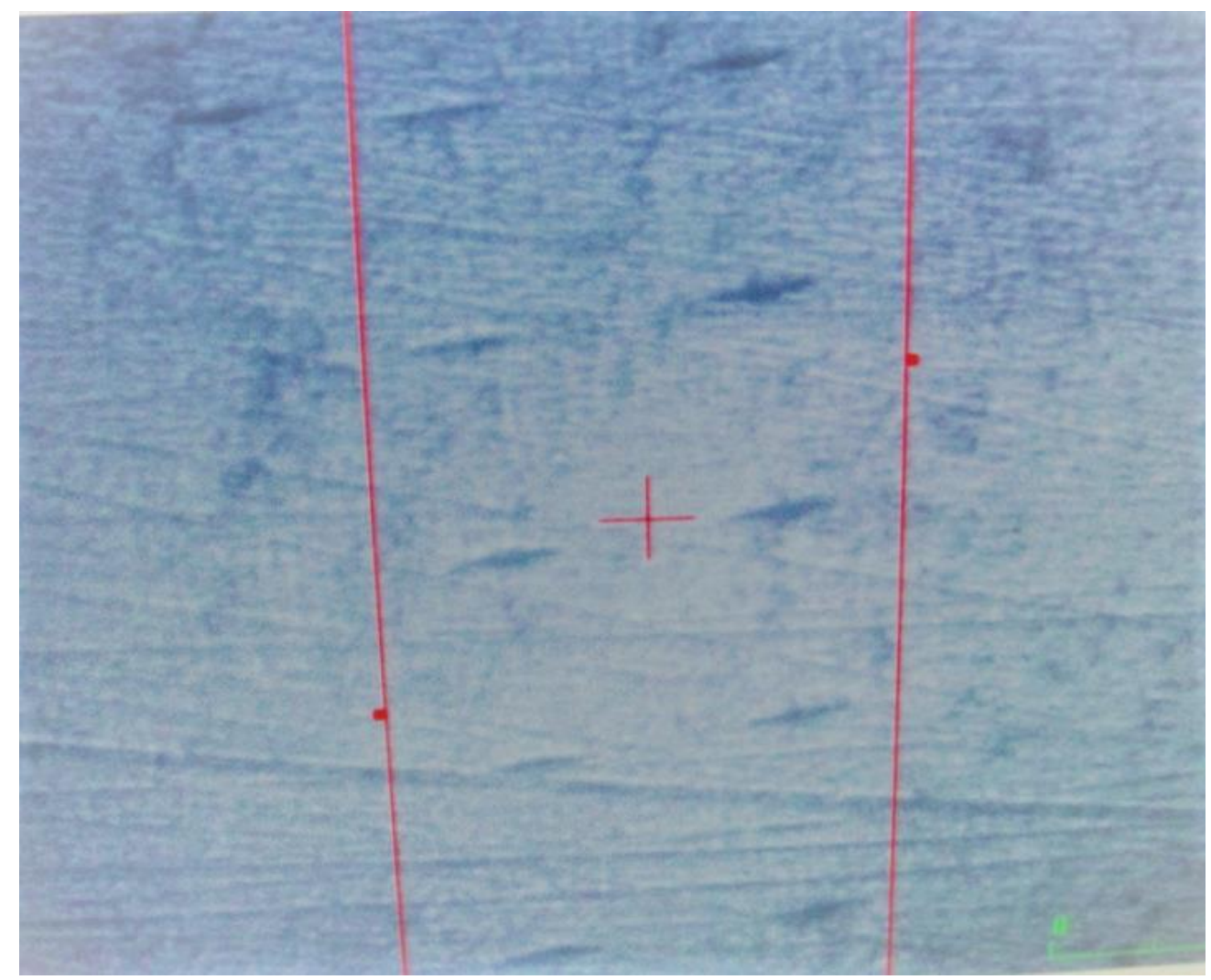

Fonte: Autor

Após estas indentações de baseline, foi calculada a média e desvio padrão das 15 indentações de cada amostra para verificar se a mesmo era homogênea com a finalidade de critério de inclusão conforme os valores de microdureza determinados na literatura, por outro lado para diminuir um desvio padrão menor quando realizada a dispersão dos dados. Foram realizados gráficos de dispersão no Microsoft Excel (Microsoft Office, 2013) para cada grupo, desta conseguiu-se realizar uma seleção acurada das amostras a serem irradiadas. Para o caso do esmalte dentário e segundo a dispersão inicialmente realizada, como apresentada na Figura 16, houve um descarte das amostras por abaixo da linha reta representante da média dos valores de microdureza inicial obtidos para este tecido, pelo qual realizou-se um preparo de blocos extras em um segundo e terceiro momento, como mostrado na Figura 17 e Figura 18. Para o caso da dentina radicular e segundo o gráfico de dispersão inicial visualizado na 
Figura 19 houve descarte das amostras que não incluíam-se na média dos valores de microdureza de superfície inicial referenciados pela literatura, pelo qual preparou-se blocos extras para posterior análise e posteriormente realizou-se uma segunda dispersão dos dados, como evidenciado na Figura 20. No caso do corpo mandibular e região do trígono molar, como apresentados na Figura 21 e Figura 22 realizou-se em ambos os casos uma dispersão inicial das médias dos valores iniciais de microdureza de superfície para seleção das amostras a serem irradiadas.

Figura 16. Dispersão - valores iniciais de microdureza de superfície do esmalte dentário

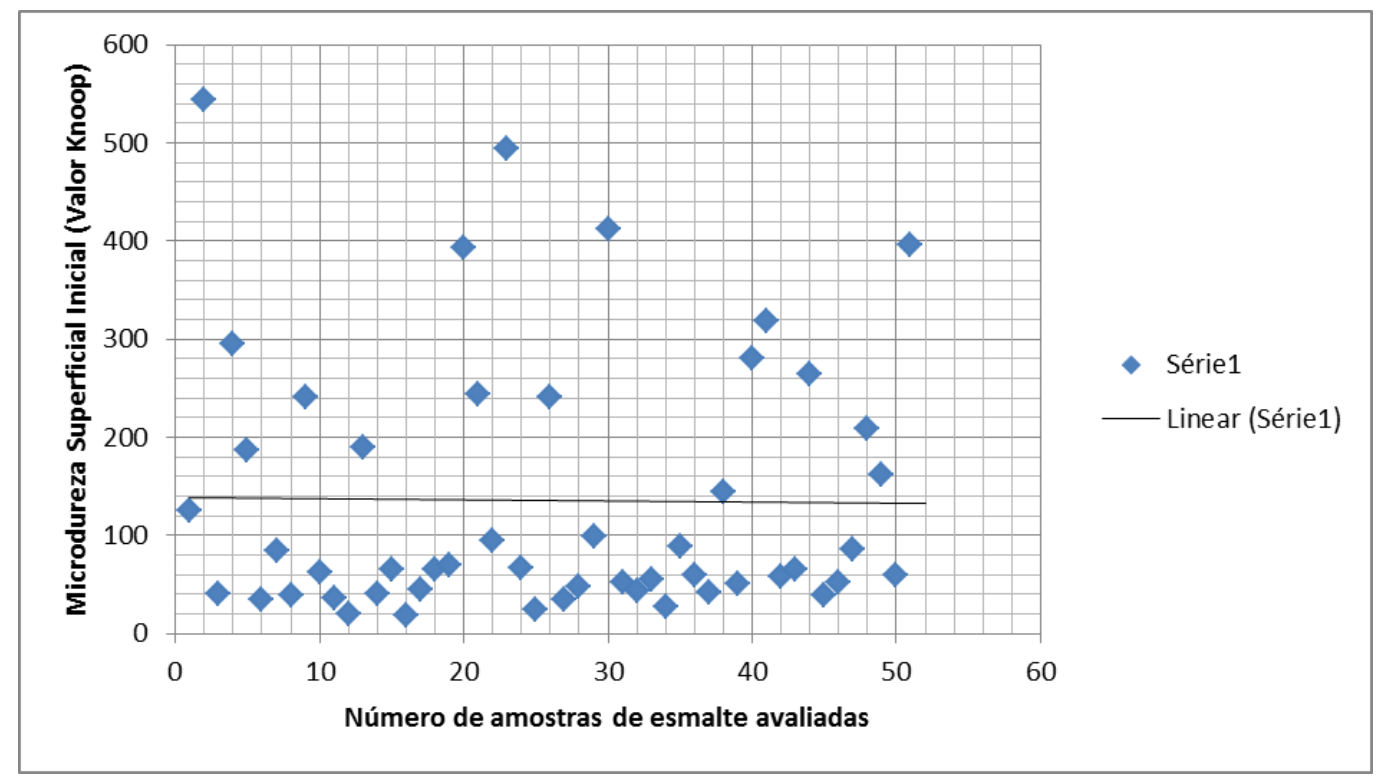

Fonte: Elaborado pelo autor no programa Microsoft Excel, Microsoft Office 2013 
Figura 17. Dispersão - valores iniciais de microdureza de superfície do esmalte dentário extras (segundo grupo)

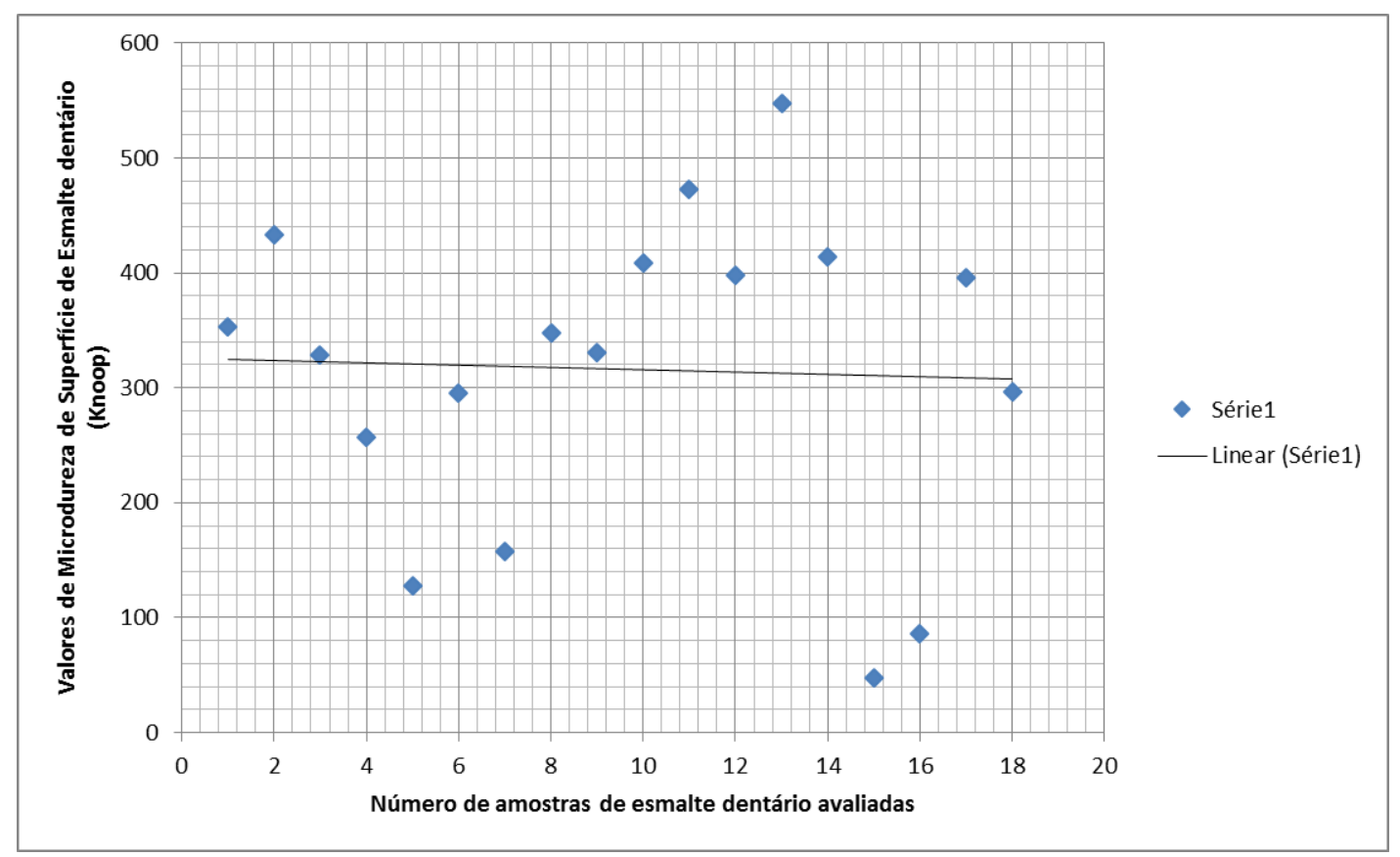

Fonte: Elaborado pelo autor no programa Microsoft Excel. Microsoft Office 2013

Figura 18. Dispersão - valores iniciais de microdureza de superfície do esmalte dentário extras (terceiro grupo)

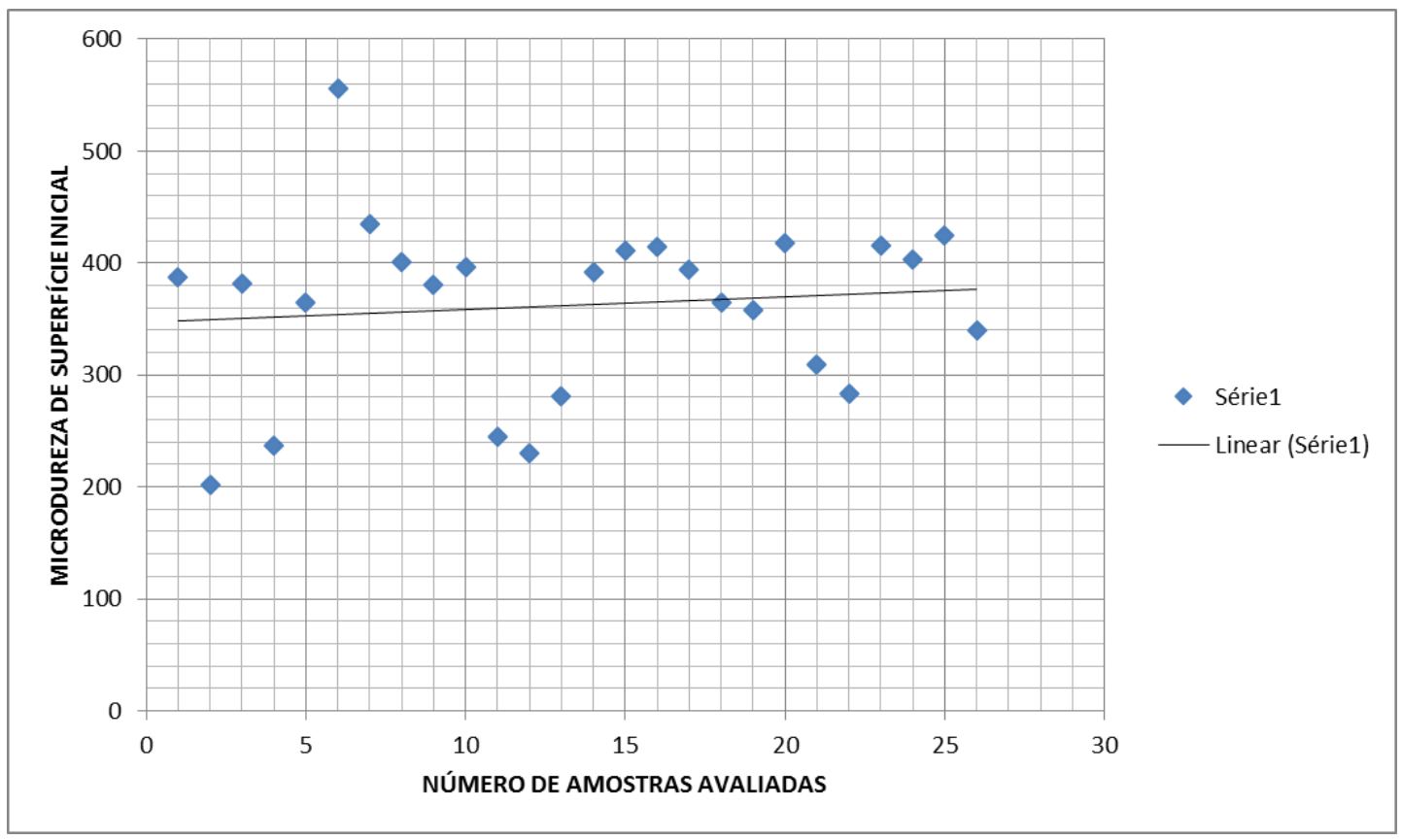

Fonte: Elaborado pelo autor no programa Microsoft Excel. Microsoft Excel 2013 
Figura 19. Dispersão - valores iniciais de microdureza de superfície da dentina radicular

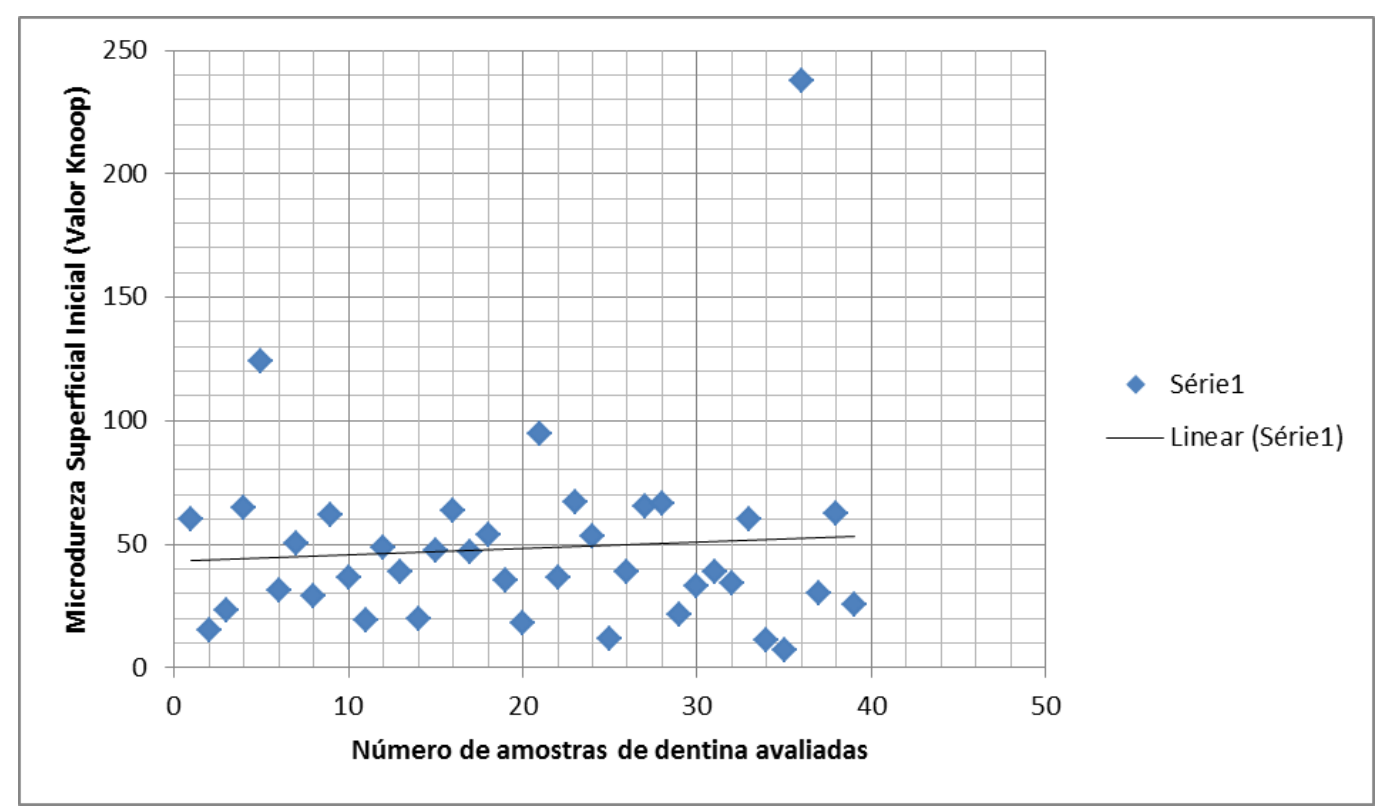

Fonte: Elaborado pelo autor no programa Microsoft Excel. Microsoft Office 2013

Figura 20. Dispersão - valores iniciais de microdureza de superfície da dentina radicular (segundo grupo)

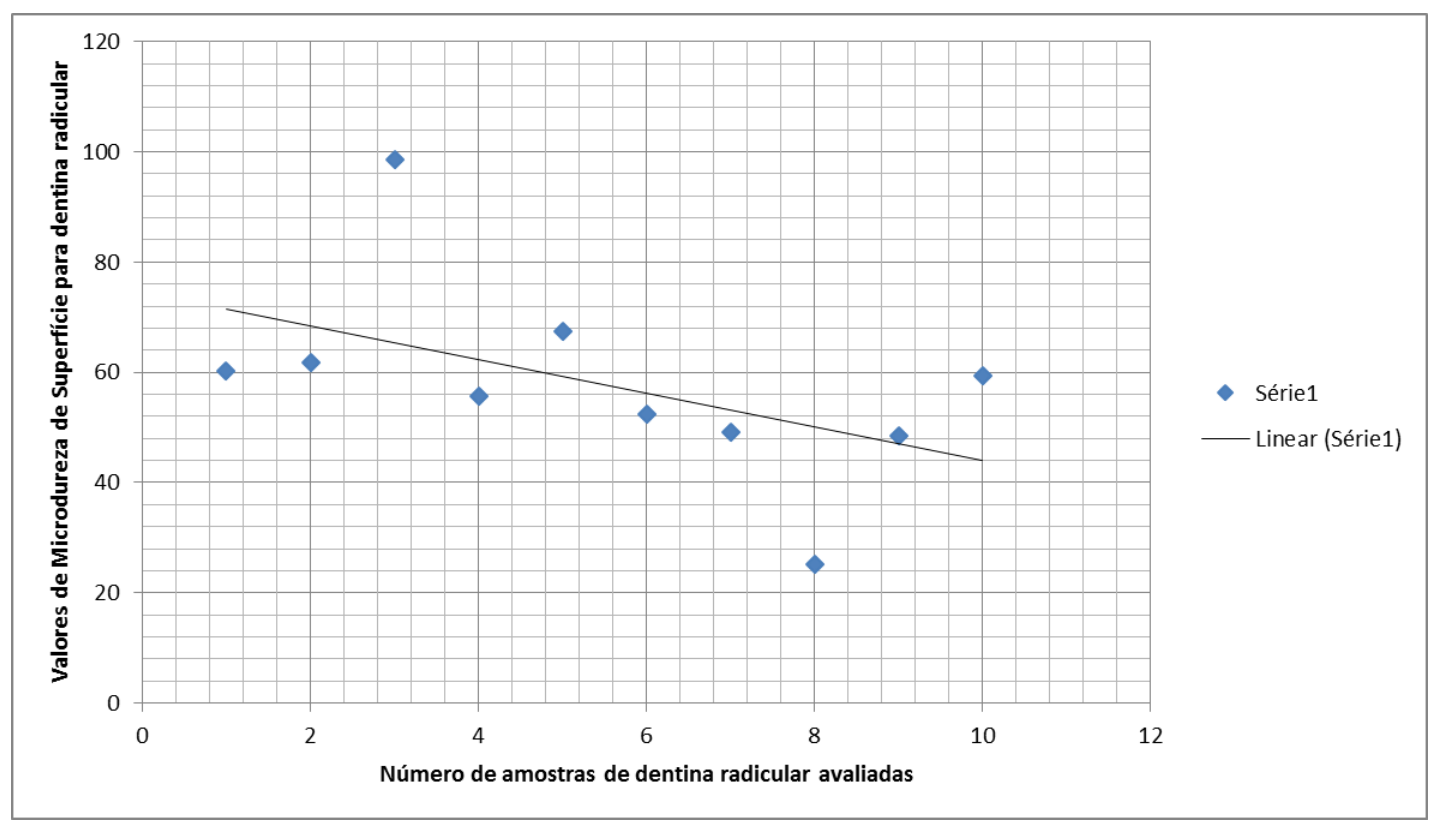

Fonte: Elaborado pelo autor no programa Microsoft Excel. Microsoft Office 2013 
Figura 21. Dispersão - valores iniciais de microdureza de superfície do corpo mandibular

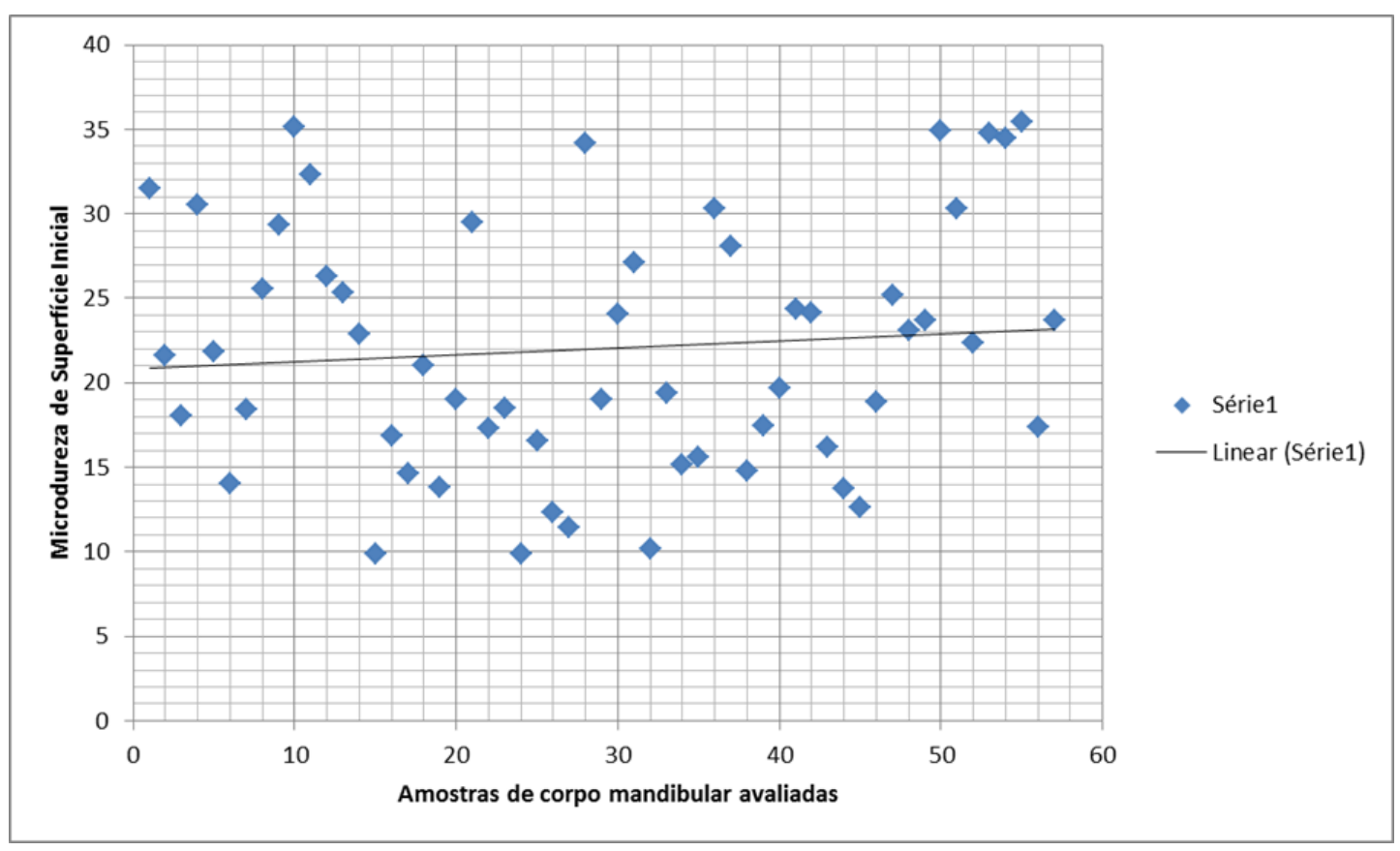

Fonte: Elaborado pelo autor no programa Microsoft Excel, Microsoft Office 2013

Figura 22. Dispersão - valores iniciais de microdureza de superfície do trígono retromolar

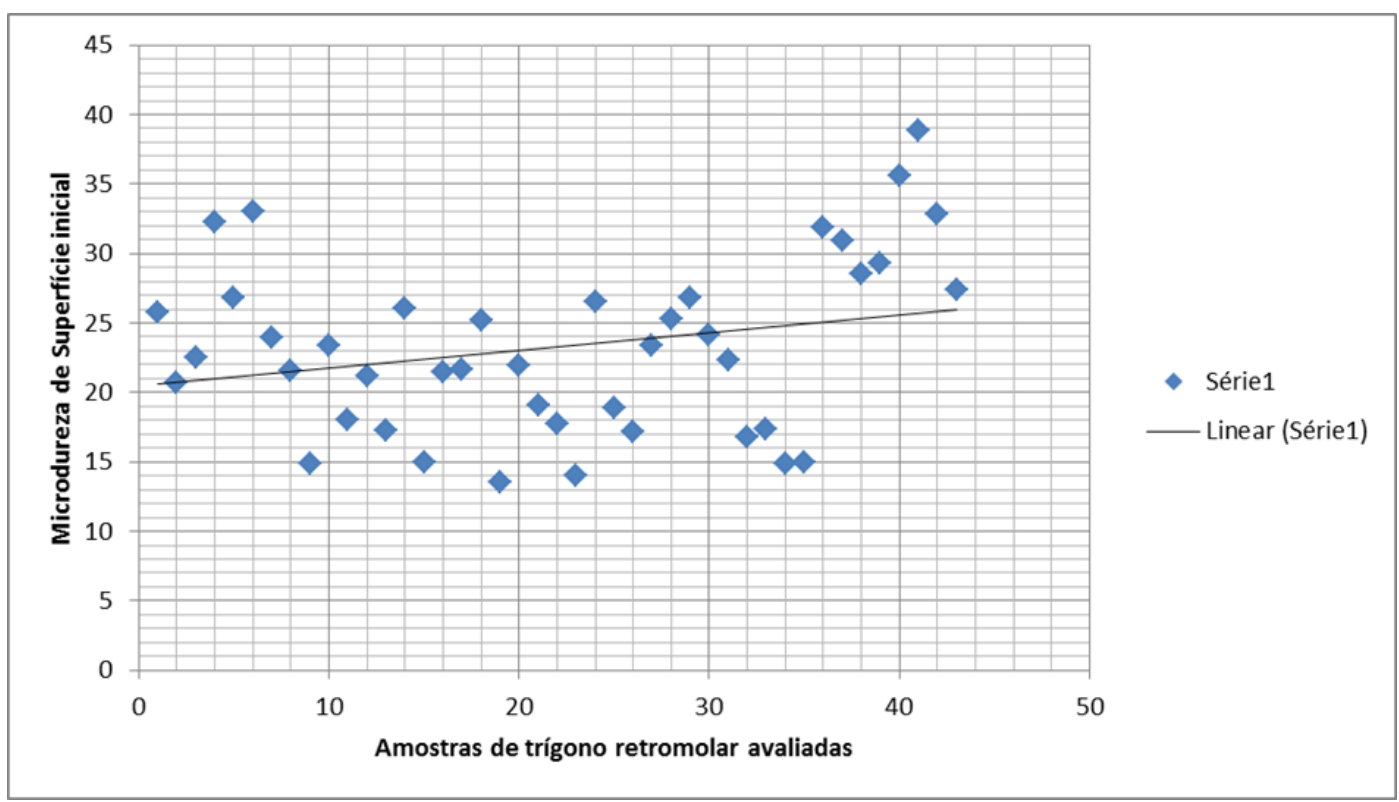

Fonte: Elaborado pelo autor no programa Microsoft Excel, Microsoft Office 2013 


\section{5 IRRADIAÇÃO DAS AMOSTRAS}

As amostras foram submetidas à irradiação gama no Irradiador de Cobalto-60 (GammaCell, Co-60), com uma taxa de dose do equipamento (Outubro 2015) de 956Gy/h e uma dose de trânsito (Outubro 2015) de 0,81Gy, localizado no Centro de Tecnologia das Radiações (CTR) do Instituto de Pesquisas Energéticas e Nucleares (IPEN-CNEN/SP, Brasil), como apresentado na Figura 23, segundo protocolo de radioterapia convencional utilizado nos pacientes acometidos por câncer de cabeça e pescoço. As amostras foram colocadas em placas de Petri de material resinoso para cultivo, e em seguida, estas foram submersas em campos de algodão umidificados com uma solução de Timol diluído em água destilada $(0,641 \mathrm{~g} /$ 1litro de água destilada) [52], com a finalidade de manter o ambiente úmido e evitar a proliferação de fungos.

Figura 23. Fonte Gammacell Cobalto -60

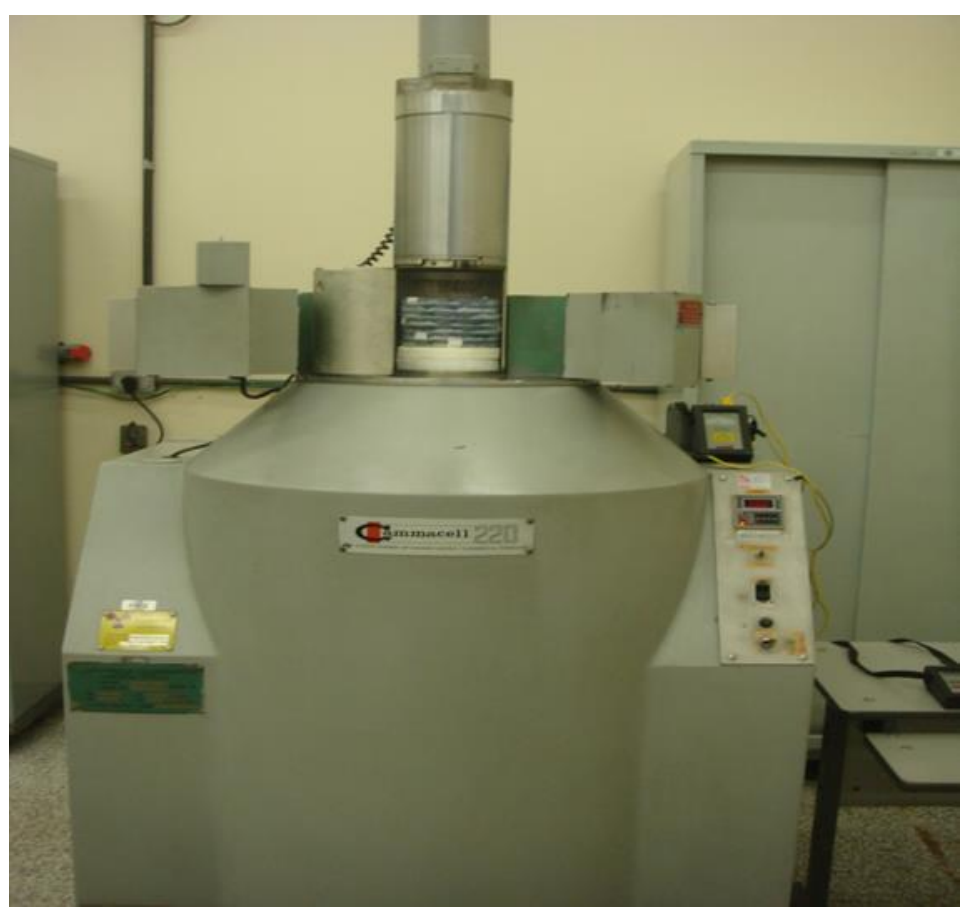

Fonte: Autor

\section{5. 1 Estudo piloto para determinação da taxa de dose}

Para determinar a taxa de dose a ser empregada no estudo foi realizado um estudo piloto com amostras de dentina radicular, conformando-se dois grupos de 5 amostras cada, 
as quais foram submetidas a duas taxas de dose diferentes no Irradiador Co-60 (Fonte GammaCell), como apresenta-se na Figura 24:

1. - O primeiro grupo foi submetido a uma taxa de dose de $10 \mathrm{~Gy} / 2,2$ s, como dose única. Em seguida, realizou-se a irrigação do campo com a solução de Timol e água destilada, e foi armazenada sob refrigeração $4{ }^{\circ} \mathrm{C}$.

2. - O segundo grupo foi submetido a uma taxa de dose fracionada de $2 \mathrm{~Gy} / 4,4$ s durante 5 dias consecutivos até completar uma dose total de 10Gy. Após cada irradiação as amostras foram irrigadas com a solução descrita anteriormente e armazenadas sob refrigeração de $4^{\circ} \mathrm{C}$.

Ambos os grupos foram submetidos à análise de MDS. Após irradiação, realizou-se o cálculo de média e o desvio padrão das 15 indentações realizadas. Segundo os resultados obtidos nos gráficos de dispersão e a plotagem, o estudo piloto indicou uma maior variabilidade dos resultados das médias iniciais e finais de MDS com a taxa de dose 10Gy, conforme a desvio padrão obtido, pelo qual resolveu-se usar a taxa de dose fracionada de 2Gy/4,4s, para todos os grupos em estudo, conforme mostra a Figura 25.

Figura 24. Amostras do estudo acondicionadas nas placas de Petri

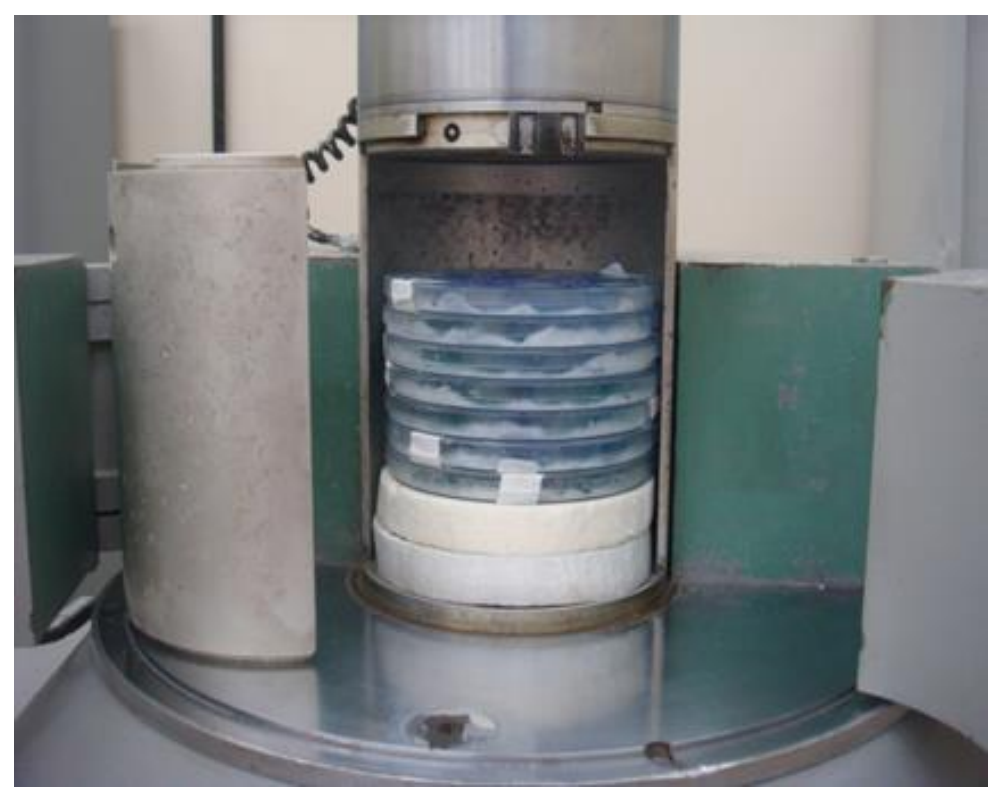

Fonte: Autor 
Figura 25. Média da microdureza de superfície para determinação da taxa de dose - 2Gy e 10 Gy

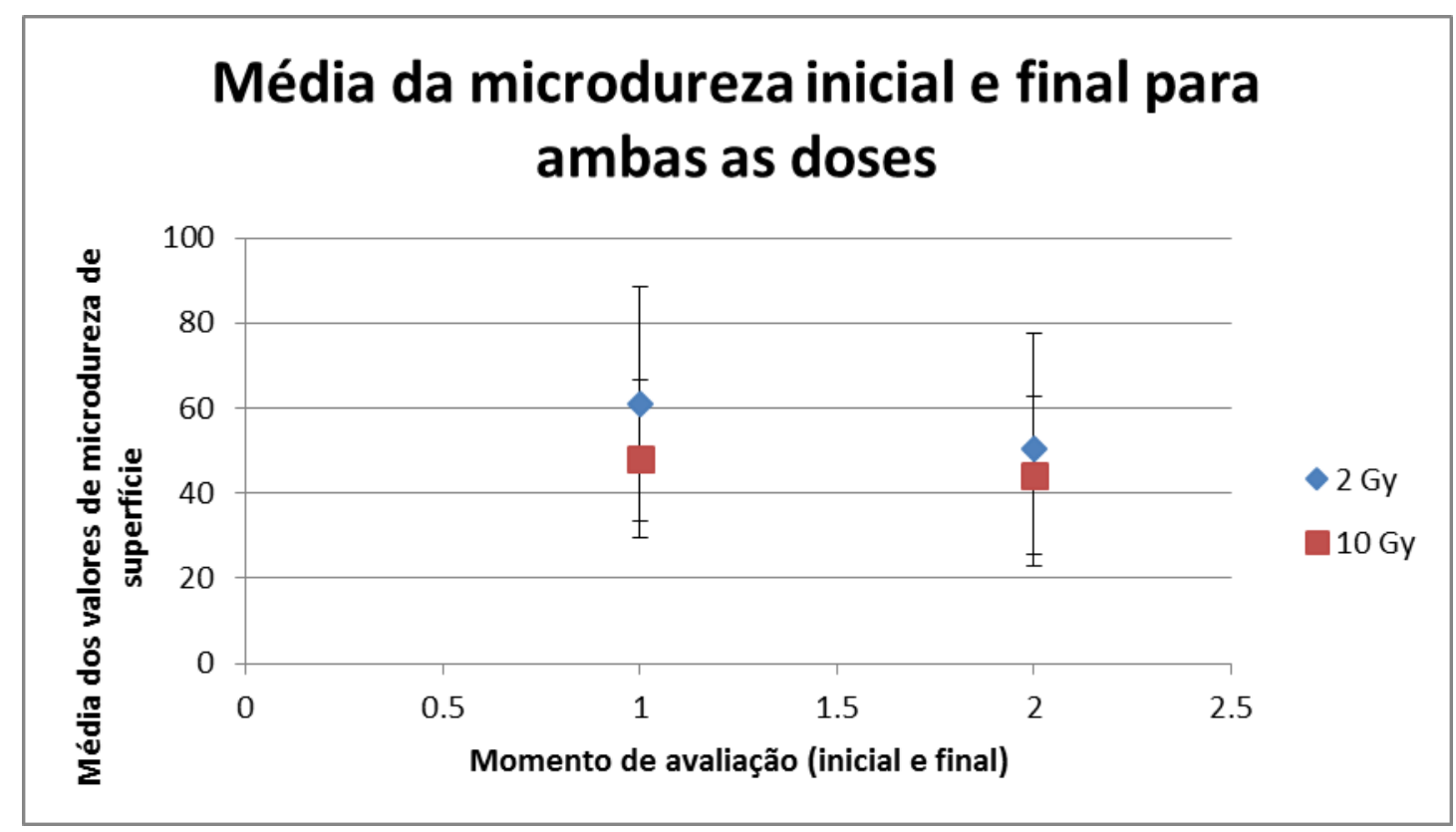

Fonte: Elaborado pelo autor no programa Microsoft Excel, Microsoft Office 2013

\section{5. 2 Irradiação das amostras de esmalte dentário}

As amostras de esmalte dentário foram colocadas em placas de Petri submersas em algodão umidificado com a solução de Timol e água destilada como descrito anteriormente no estudo piloto. Estas foram distribuídas em 5 amostras por cada placa de Petri.

Em seguida, deu-se início ao protocolo de irradiação no Irradiador de Cobalto-60 (Fonte GammaCell, Co-60) com uma taxa de dose do equipamento para o mês de março de 2016 de $903 \mathrm{~Gy} / \mathrm{h}$, uma dose de trânsito de 0,76Gy e, finalmente, uma taxa de dose de 2Gy/ 4,94s. Foi realizada a irradiação duas vezes por dia (4Gy por dia) com um intervalo de 8 horas para cada irradiação, durante 5 dias até completar uma dose semanal de 20Gy. Após a segunda irradiação do dia, as amostras foram submetidas à irrigação com a solução de Timol e de água destilada e posteriormente foram armazenadas sob refrigeração $4^{\circ} \mathrm{C}$.

\subsubsection{Irradiação das amostras de dentina radicular}

As amostras de dentina radicular foram submersas em algodão, umidificado com a solução de Timol e água destilada e colocadas nas placas de Petri. Estas foram submetidas à irradiação gama, com as características anteriormente descritas. As amostras receberam uma 
taxa de dose fracionada de $2 \mathrm{~Gy} / 4,94$ s duas vezes no dia, completando semanalmente uma dose de 20Gy. A dose total de irradiação foi de 72Gy. Foi realizada a reidratação das amostras após o segundo tempo de irradiação no dia.

\section{5. 4 Irradiação das amostras de trígono retromolar}

No caso das amostras de trígono retromolar foi realizado o procedimento previamente descrito para a dentina radicular e o esmalte dentário. Estas foram acondicionadas nas placas de Petri umidificadas com a solução de Timol e de agua destilada para manter um ambiente úmido e livre de crescimento de fungos. Os blocos foram submetidos à irradiação diária com uma taxa de dose de $2 \mathrm{~Gy} / 4,94$ s duas vezes no dia até completar uma dose semanal de $20 \mathrm{~Gy}$. Após o segundo tempo de irradiação, a qual foi realizada em um intervalo de aproximadamente 8 horas realizou-se a reidratação das amostras e estas finalmente foram armazenadas sob refrigeração de $4^{\circ} \mathrm{C}$ para as próximas irradiações.

\section{5. 5 Irradiação das amostras de corpo mandibular}

O grupo de amostras de corpo mandibular suíno foi colocado em placas de Petri distribuídas em subgrupos de 5 amostras por cada placa, as quais foram submersas em algodão umidificado para manutenção do ambiente úmido e inibição de crescimento fúngico. Estas foram submetidas à irradiação gama, com uma taxa de dose fracionada de 2Gy/4,94 s duas vezes por dia, até completar uma dose semanal de 20Gy, e uma dose total de $72 \mathrm{~Gy}$. Após o segundo tempo de irradiação, as placas de Petri foram reidratadas e armazenadas sob refrigeração de $4^{\circ} \mathrm{C}$.

\section{6 ANÁLISE DE PERCENTUAL DE PERDA DE DUREZA SUPERFÍCIE}

Após as amostras serem submetidas à irradiação gama segundo protocolo estabelecido e descrito anteriormente, executou-se a avaliação final da microdureza de superfície de cada grupo. Cada amostra foi posicionada no microdurômetro (Shimadzu HMV2000.Shimadzu, Japão) para localização da borda inicial usada como referência na primeira análise de dureza; em seguida, calculou-se uma distância de separação de $200 \mu \mathrm{m}$ entre a primeira e segunda indentação com a finalidade de avaliar-se as variações da dureza na região envolvida e analisada inicialmente. Foram realizadas cinco indentações por fila, separadas uma da outra com uma distância de $100 \mu \mathrm{m}$, completando-se finalmente as 15 indentações finais para cada amostra dos grupos em estudo. 
Os dados obtidos foram registrados na planilha inicial de avaliação (apresentada no Anexo A). Em seguida, as amostras forma submetidas à análise de \% perda de microdureza de superfície ou testes biológicos com a finalidade de aferir a integridade das amostras. $\mathrm{O}$ cálculo de \% de perda de dureza de superfície é matematicamente representado pela equação: \% Variação de Dureza de Superfície = MDS Inicial - MDS Pós-tratamento x 100 / MDS Inicial A determinação da \% de perda de microdureza de superfície após a irradiação gama é um controle intra-amostra, aferindo a segurança do método utilizado com relação à manutenção da homogeneidade.

\section{7 ANÁLISE POR MICROSCOPIA ELETRÔNICA DE VARREDURA (MEV)}

Quatro amostras por cada grupo foram selecionadas aleatoriamente para serem avaliadas morfologicamente através da microscopia eletrônica de varredura (MEV). Em um primeiro momento as amostras foram tratadas e preparadas (condicionamento inicial) fisicamente para posterior análise no MEV. Escolheram-se diferentes concentrações de etanol com a finalidade de desidratar-se cada amostra incluída em uma escala crescente: 10\%, $30 \%, 50 \%, 70 \%, 90 \%, 96 \%$ e $100 \%$ por 15 minutos em cada solução. Logo em seguida, as mostras ficaram no dissecador de sílica durante 24 horas (tempo mínimo) para posterior análise no MEV.

As amostras foram examinadas no microscópio eletrônico de varredura TM 3000 Tabletop Microscope (Hitachi, Japan) do Centro de Caracterização e Tecnologia dos Materiais (CCTM) no IPEN-CNEN/SP, Brasil, com uma tensão de $15 \mathrm{Kv}$ para obtenção de maior resolução da imagem com uma ampla especificidade da superfície a ser analisada. Para facilitar a fixação da amostra no porta-amostras do MEV empregou-se uma fita dupla adesiva de carbono, condutora. Os grupos avaliados foram constituídos de:

1) Grupo de esmalte dentário controle (duas amostras antes da irradiação gama);

2) Grupo de esmalte dentário experimental (duas amostras após a irradiação gama);

3) Grupo de dentina radicular controle (duas amostras antes da irradiação gama);

4) Grupo de dentina radicular experimental (duas amostras após a irradiação gama);

5) Grupo de corpo mandibular controle (duas amostras antes da irradiação gama); 
6) Grupo de corpo mandibular experimental (duas amostras após a irradiação gama);

7) Grupo da região do trígono retromolar controle (duas amostras antes da irradiação gama);

8) Grupo da região do trígono retromolar experimental (duas amostras após a irradiação gama).

\section{8 ANÁLISE POR ESPECTROSCOPIA ATR - FTIR}

As amostras irradiadas e não irradiadas foram analisadas por Espectroscopia no Infravermelho por transformada de Fourier, no equipamento Espectrômetro infravermelho FTIR (Perkin - Elmer, 100) do Centro de Tecnologia das Radiações (CTR) do IPEN/CNEN, SP, Brasil, cujos espectros foram obtidos por reflexão total atenuada (ATR), numa faixa de frequência de $4000 \mathrm{~cm}^{-1}$ a $650 \mathrm{~cm}^{-1}$, e uma precisão de aquisição de $4 \mathrm{~cm}^{-1}$. Optou-se por uma maior quantidade de varreduras seguindo as últimas publicações da literatura mais recente [48], [51] para obtenção de espectros de tecido duro da cavidade bucal, completandose um total de 80 varreduras com subtração do background (BG). $\mathrm{O}$ cristal que compunha o equipamento para a análise foi o seleneto de zinco ( $\mathrm{ZnSe})$, para se obter uma análise bioquímica e semi-quantitativa do conteúdo orgânico e inorgânico nelas presente nelas. As amostras foram descoladas das lâminas de acrílico e foram posicionadas acima do cristal de ZnSe para obtenção dos espectros gerados pela transformada de Fourier. Logo depois das amostras serem descoladas e posicionadas centralmente no cristal, seguiu-se o ajustamento contra o cristal usando uma determinada força de torque de $130 \mathrm{~N}$, o qual permitiu uma análise exata e acurada das amostras, ilustrada na Figura 26. 
Figura 26. Análise das amostras pela técnica de reflexão total atenuada aplicando-se uma força de torque de $130 \mathrm{~N}$

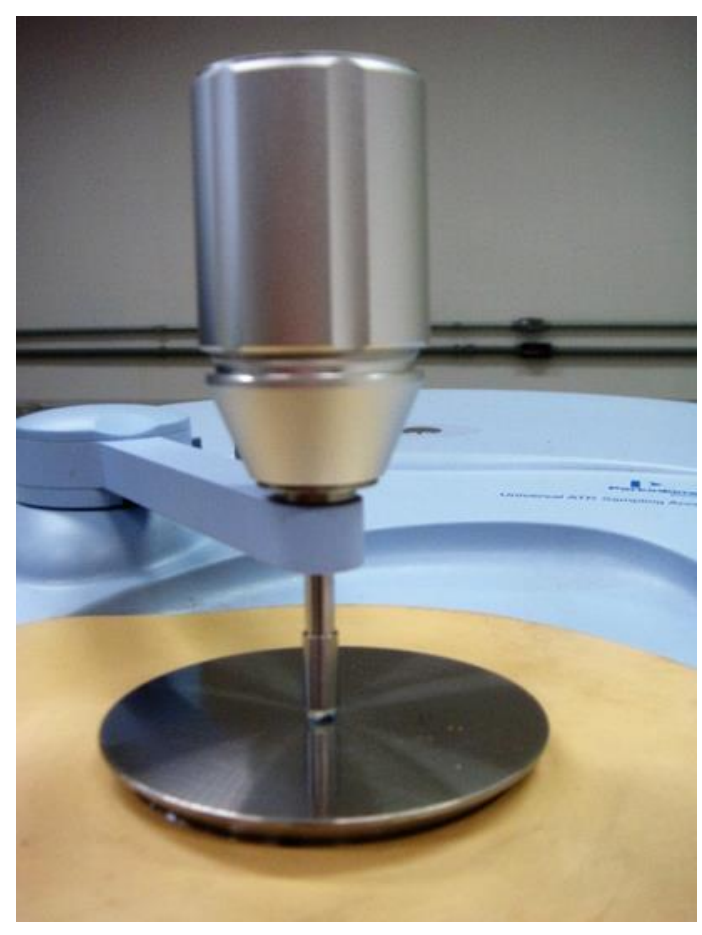

Fonte: Autor

Foram obtidos oito espectros para o caso das amostras controle, ou seja, aquelas que não foram submetidas à irradiação gama, e foram subdivididos:

- Esmalte dentário: um espectro para a amostra controle identificada como E40REF e outro para o caso da amostra controle identificada como E69REF.

- Dentina radicular: um espectro para a amostra controle identificada como D81REF e outro para o caso da amostra controle identificada como D52REF.

- Corpo mandibular: um espectro para a amostra controle de CM58REF e outro para o caso da amostra controle identificada como CM50REF.

- Região do trígono retromolar: um espectro para a mostra controle identificada como TRM55REF e outro para o caso da amostra controle identificada como TRM56REF. 


\section{RESULTADOS}

\section{1 ANÁLISE DE MICRODUREZA DE SUPERFÍCIE (MDS)}

Os resultados obtidos da microdureza de superfície foram analisados e submetidos à análise estatística com um nível de confiança de 95\% no programa Statiscal Package for Social Science, SPSS versão 18 para Windows. A partir dos valores da média e desvio padrão obtidos e segundo o teorema de Lindeberg - Lévy (teorema do limite central ou central limit teorema-CLT), o qual estabelece que a distribuição da média provenientes de dados individuais e independentes é normal, e como os dados analisados neste estudo, pertencentes a médias individuais e independentes, usou-se dito postulado para determinar-se a distribuição normal dos dados obtidos correspondentes às médias dos valores iniciais e finais da microdureza de superfície de todos os grupos de estudo. Uma vez determinada a distribuição normal das médias de microdureza de superfície, tanto iniciais quanto finais, aplicou-se a prova estatística paramétrica de t de student para médias relacionadas com a finalidade de testar a hipótese de nulidade, conforme apresentado a seguir:

Ho: Não existe diferença significativa entre os valores iniciais de microdureza de superfície quando comparadas com os valores finais nas amostras dos tecidos duros da cavidade bucal submetidos à irradiação gama.

A Tabela 1 apresenta a média e erro padrão dos valores iniciais e finais de microdureza de superfície no esmalte.

Tabela 1. Média e erro padrão da microdureza de superfície no esmalte dentário

\begin{tabular}{cccc}
\hline & & Média & $\begin{array}{c}\text { Erro padrão da } \\
\text { média }\end{array}$ \\
Par 1 & Inicial & 354,50 & 3,83 \\
& Final & 301,67 & 3,44 \\
\hline
\end{tabular}

Fonte: Elaborado pelo autor no programa SPSS versão 18 para Windows 


\section{Estatística descritiva:}

1. O número de indentações avaliadas foi de $\mathrm{n}=732 \mathrm{em}$ cada bloco de esmalte antes e após a irradiação gama, obtendo-se uma diferença entre a média inicial e final dos valores de microdureza de superfície de aproximadamente 53 pontos.

2. O erro padrão da média dos valores iniciais de microdureza de superfície foi de 3,83 , e para o caso dos valores finais foi de 3,44, representando em ambos os casos valores pequenos que oferecem uma maior margem de segurança dos dados obtidos.

A Tabela 2 apresenta o teste $t$ de student para análise da diferença das médias relacionadas (inicial e final) dos valores de microdureza de superfície das amostras de esmalte dentário.

Tabela 2. Teste $t$ de student da microdureza de superfície do esmalte dentário

\begin{tabular}{|c|c|c|c|c|c|c|c|c|}
\hline \multicolumn{9}{|c|}{ Prova de amostras relacionadas } \\
\hline & & \multicolumn{4}{|c|}{ Diferenças relacionadas } & \multirow[t]{3}{*}{$\mathbf{t}$} & \multirow{3}{*}{$\begin{array}{c}\text { gl } \\
\text { (grau } \\
\text { s de } \\
\text { liberd } \\
\text { ade) }\end{array}$} & \multirow{3}{*}{$\begin{array}{l}\text { P - valor } \\
\text { (<0,05\%) } \\
\text { (Bilateral) }\end{array}$} \\
\hline & & \multirow[t]{2}{*}{ Média } & \multirow[t]{2}{*}{$\begin{array}{c}\text { Erro } \\
\text { padrão da } \\
\text { média }\end{array}$} & \multicolumn{2}{|c|}{$\begin{array}{c}95 \% \text { Intervalo de } \\
\text { confiança para a } \\
\text { diferença }\end{array}$} & & & \\
\hline & & & & Inferior & Superior & & & \\
\hline $\begin{array}{c}\text { Par } \\
1\end{array}$ & $\begin{array}{c}\text { Inicial - } \\
\text { Final }\end{array}$ & 52,823 & 3,916 & 45,134 & 60,512 & 13,488 & 731 & 0,00 \\
\hline
\end{tabular}

Fonte: Elaborado pelo autor no programa SPSS versão 18 para Windows

O quadro resumo apresentado na Tabela 2 mostra que a hipótese de nulidade foi recusada, já que se obteve um valor de $\mathrm{p}<0,05 \%$ (0,00\%); por conseguinte, existe diferença estatisticamente significativa entre os valores iniciais e finais de microdureza de superfície nas amostras de esmalte dentário.

A Tabela 3 apresenta a média e erro padrão dos valores de microdureza de superfície inicial e final, nas amostras de dentina radicular. 
Tabela 3. Média e erro padrão da microdureza de superfície da dentina radicular

\begin{tabular}{cccc}
\hline & Média & $\begin{array}{c}\text { Erro padrão da } \\
\text { média }\end{array}$ \\
\hline Par 1 & Inicial & 54,30 & 0,79 \\
& Final & 33,32 & 0,78 \\
\hline & & \\
\hline
\end{tabular}

\section{Estatística descritiva:}

1. Após a avaliação de $n=642$ indentações realizadas nos blocos de dentina apresentou-se uma diminuição de aproximadamente 20 pontos de diferença entre a média inicial e final dos valores de microdureza de superfície.

2. O erro padrão da média dos valores iniciais de microdureza de superfície foi de 0,79 , e para o caso da média dos valores finais foi de 0,78 , representando em ambos os casos valores pequenos de erro que oferecem uma maior margem de segurança dos dados obtidos.

A Tabela 4 apresenta o teste de t de student para análise da diferença das médias relacionadas (inicial e final) dos valores de microdureza de superfície nas amostras de dentina radicular. 
Tabela 4. Teste $t$ de student da microdureza da dentina radicular

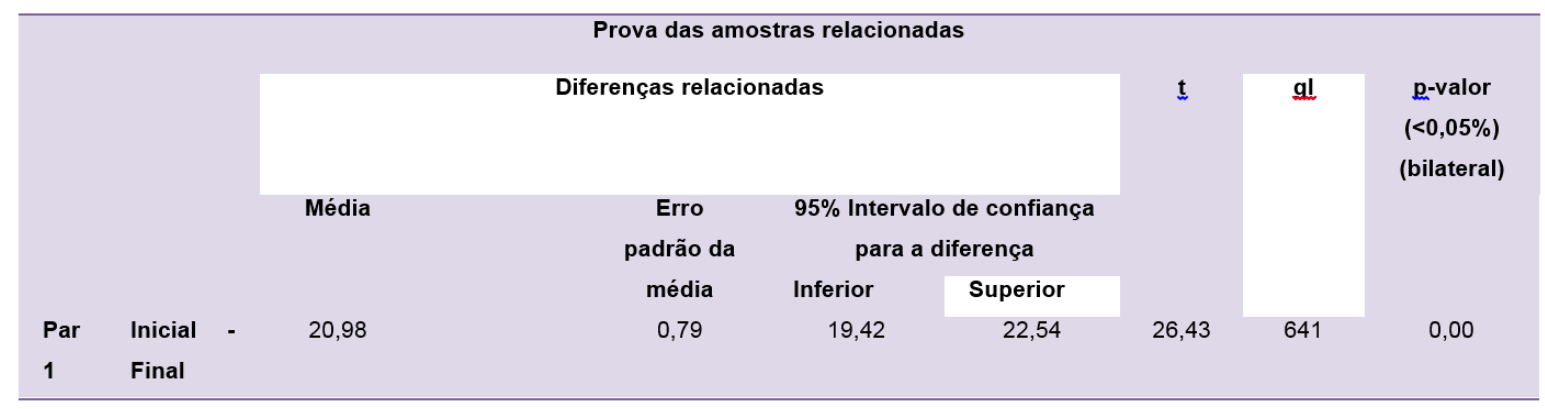

Fonte: Elaborado pelo autor no programa SPSS versão 18 para Windows

O quadro resumo apresentado na Tabela 4 mostra que a hipótese de nulidade foi recusada, já que se obteve um valor de $\mathrm{p}<0,05 \%(0,00 \%)$; por conseguinte, existe diferença estatisticamente significativa entre os valores iniciais e finais de microdureza de superfície nas amostras de dentina radicular.

A Tabela 5 mostra a média e erro padrão dos valores de microdureza de superfície inicial e final das amostras de corpo mandibular.

Tabela 5. Média e erro padrão da microdureza de superfície do corpo mandibular

\begin{tabular}{c|ccc}
\hline & Média & $\begin{array}{c}\text { Erro padrão da } \\
\text { média }\end{array}$ \\
\hline \multirow{2}{*}{ Par 1 } & Inicial & 21,66 & 0,38 \\
& Final & 15,61 & 0,26 \\
\hline
\end{tabular}

Fonte: Elaborado pelo autor no programa SPSS versão 18 para Windows 


\section{Estatística descritiva:}

1. Após a avaliação de $n=752$ indentações realizadas nos blocos de corpo mandibular apresentou-se uma diferença entre a média inicial e final de aproximadamente 6 pontos correspondente aso valores iniciais e finais de microdureza de superfície.

2. O erro padrão da média dos valores iniciais de microdureza de superfície foi de 0,38 , e para o caso da média dos valores finais foi de 0,26 , representando em ambos os casos valores pequenos de erro que oferecem uma maior margem de segurança dos dados obtidos.

A Tabela 6 mostra o teste de $\mathrm{t}$ de student para análise da diferença das médias relacionadas (inicial e final) dos valores de microdureza de superfície das amostras de corpo mandibular.

Tabela 6. Teste $t$ de student da microdureza do corpo mandibular

\begin{tabular}{|c|c|c|c|c|c|c|c|c|}
\hline \multicolumn{9}{|c|}{ Prova das amostras relacionadas } \\
\hline & & \multicolumn{4}{|c|}{ Diferenças relacionadas } & \multirow[t]{4}{*}{$\mathbf{t}$} & \multirow{4}{*}{$\begin{array}{c}\text { gl } \\
\text { (graus } \\
\text { de } \\
\text { liberd } \\
\text { ade) }\end{array}$} & \multirow{4}{*}{$\begin{array}{c}\text { p- valor } \\
\text { (<0,05\%) } \\
\text { (bilateral) }\end{array}$} \\
\hline & & \multirow[t]{3}{*}{ Média } & \multirow{3}{*}{$\begin{array}{c}\text { Erro } \\
\text { padrão da } \\
\text { média }\end{array}$} & \multirow{2}{*}{\multicolumn{2}{|c|}{$\begin{array}{c}\text { 95\% Intervalo de confiança } \\
\text { para a diferença }\end{array}$}} & & & \\
\hline & & & & & & & & \\
\hline & & & & Inferior & Superior & & & \\
\hline $\begin{array}{c}\text { Par } \\
1\end{array}$ & $\begin{array}{c}\text { Inicial - } \\
\text { Final }\end{array}$ & 6,05 & 0,39 & 5,28 & 6,83 & 15,32 & 751 & 0,00 \\
\hline
\end{tabular}

Fonte: Elaborado pelo autor no programa SPSS versão 18 para Windows

O quadro resumo apresentado na Tabela 6 mostra que a hipótese de nulidade foi recusada, já que se obteve um valor de p <0,05\% (0,00\%); por conseguinte, existe diferença estatisticamente significativa entre os valores iniciais e finais de microdureza de superfície nas amostras de corpo mandibular, além de apresentar uma diferença positiva da média, e um erro padrão de 0,39 , o qual fornece uma margem de segurança maior dos dados. 
A Tabela 7 mostra a média e erro padrão dos valores de microdureza de superfície inicial e final nas amostras da região do trígono retromolar.

\section{Tabela 7. Média e erro padrão da microdureza de superfície do trígono retromolar}

\begin{tabular}{cccc}
\hline & & Média & $\begin{array}{c}\text { Erro padrão da } \\
\text { média }\end{array}$ \\
Par 1 & Inicial & 25,25 & 0,42 \\
& Final & 18,00 & 0,32 \\
\hline Fonte: Elaborado pelo autor no programa SPSS versão 18 para Windows
\end{tabular}

\section{Estatística descritiva:}

1. - Após a avaliação de $n=726$ endentações realizadas nos blocos da região do trígono retromolar obteve-se uma diferença entre a média inicial e final dos valores de microdureza de superfície de aproximadamente 07 pontos.

2. O erro padrão da média dos valores iniciais de microdureza de superfície foi de 0,42, e para o caso da média dos valores finais foi de 0,32 , representando em ambos os casos valores pequenos de erro que oferecem uma maior margem de segurança dos dados obtidos.

A Tabela 8 mostra o teste de $\mathrm{t}$ de student para análise da diferença das médias relacionadas (inicial e final) dos valores de microdureza de superfície das amostras da região do trígono retromolar. 
Tabela 8. Teste $t$ de student da microdureza de superfície do trígono retromolar

\begin{tabular}{|c|c|c|c|c|c|c|c|c|}
\hline \multicolumn{9}{|c|}{ Prova das amostras relacionadas } \\
\hline & & \multicolumn{4}{|c|}{ Diferenças relacionadas } & \multirow[t]{5}{*}{$\mathbf{t}$} & \multirow{5}{*}{$\begin{array}{c}\text { gl } \\
\text { (grau } \\
\text { s de } \\
\text { liber } \\
\text { dade) }\end{array}$} & \multirow{5}{*}{$\begin{array}{c}\text { p-valor } \\
(<0,05 \%) \\
\text { (bilateral) }\end{array}$} \\
\hline & & \multirow[t]{4}{*}{ Média } & \multirow{4}{*}{$\begin{array}{c}\text { Erro } \\
\text { padrão da } \\
\text { média }\end{array}$} & \multirow{3}{*}{\multicolumn{2}{|c|}{$\begin{array}{c}95 \% \text { Intervalo de } \\
\text { confiança para a } \\
\text { diferença }\end{array}$}} & & & \\
\hline & & & & & & & & \\
\hline & & & & & & & & \\
\hline & & & & Inferior & Superior & & & \\
\hline $\begin{array}{c}\text { Par } \\
1\end{array}$ & $\begin{array}{c}\text { Inicial - } \\
\text { Final }\end{array}$ & 7,25 & 0,47 & 6,33 & 8,17 & 15,41 & 725 & 0,00 \\
\hline
\end{tabular}

Fonte: Elaborado pelo autor no programa SPSS versão 18 para Windows

O quadro resumo apresentado na Tabela 8 mostra que a hipótese de nulidade foi recusada, já que se obteve um valor de $\mathrm{p}<0,05 \%(0,00 \%)$; por conseguinte, existe diferença estatisticamente significativa entre os valores iniciais e finais de microdureza de superfície nas amostras da região do trígono retromolar.

A Figura 27 apresenta a análise estatística de $t$ de student para estabelecer as comparações entre as médias e o desvio padrão obtidas para os valores de microdureza de superfície inicial e final entre os grupos de estudo avaliados. Segundo o gráfico, o esmalte dentário apresentou uma maior variação entre os valores iniciais e finais de microdureza de superfície, quando comparados com os outros grupos, os quais obtiveram os valores da diferença entre as médias e o erro padrão próximos. Os dados foram obtidos com um intervalo de confiança de $95 \%$. 
Figura 27. Teste de $\boldsymbol{t}$ de student para análise dos valores da média e erro padrão dos valores de microdureza de superfície inicial e final das amostras em estudo

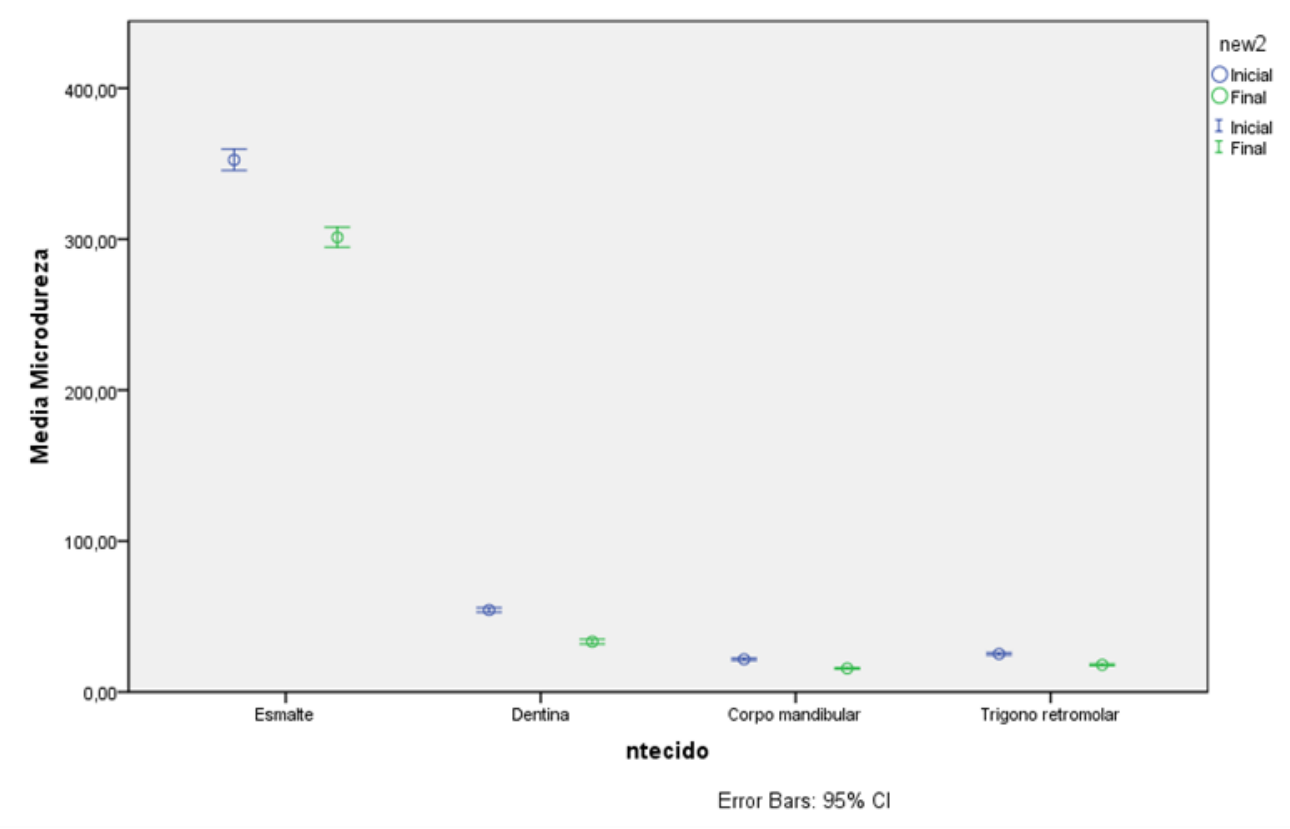

Fonte: Elaboração própria a partir dos dados obtidos das análises submetidos ao teste $t$ de student para médias relacionadas no programa SPSS. 18 para Windows

Para a análise da diferença dos valores de microdureza de superfície entre os grupos (esmalte dentário, dentina radicular, corpo mandibular e região do trígono retromolar) foi realizado o teste estatístico de variância ou ANOVA, o qual visa determinar a existência de diferença estatisticamente significante do efeito exercido pela radiação gama entre os grupos em estudo avaliando-se as diferenças de microdureza inicial e final intergrupos. As tabelas, Tabela 9, Tabela 10 e Tabela 11 a seguir apresentam os resultados obtidos através da análise: 
Tabela 9. Análise da diferença da microdureza de superfície dos grupos em estudo

\begin{tabular}{|c|c|c|c|c|c|c|c|}
\hline & \multirow[t]{2}{*}{$\mathbf{N}$} & \multirow[t]{2}{*}{ Média } & \multirow[t]{2}{*}{$\begin{array}{c}\text { Erro } \\
\text { padrão }\end{array}$} & \multicolumn{2}{|c|}{$\begin{array}{c}\text { Intervalo de confiança para } \\
\text { a média al } 95 \%\end{array}$} & \multirow[t]{2}{*}{ Mínimo } & \multirow[t]{2}{*}{ Máximo } \\
\hline & & & & $\begin{array}{l}\text { Limite } \\
\text { inferior }\end{array}$ & $\begin{array}{l}\text { Limite } \\
\text { superior }\end{array}$ & & \\
\hline Esmalte & 728 & 51,2754 & 3,45286 & 44,4966 & 58,0542 & $-277,00$ & 438,00 \\
\hline Dentina & 642 & 20,9780 & 0,79387 & 19,4191 & 22,5369 & $-45,00$ & 115,20 \\
\hline $\begin{array}{c}\text { Corpo } \\
\text { mandibular }\end{array}$ & 752 & 6,0512 & 0,39491 & 5,2760 & 6,8265 & $-71,40$ & 61,80 \\
\hline $\begin{array}{l}\text { Trígono } \\
\text { retromolar }\end{array}$ & 726 & 7,2492 & 0,47051 & 6,3254 & 8,1729 & $-42,60$ & 64,10 \\
\hline Total & 2848 & 21,2815 & 0,97742 & 19,3650 & 23,1981 & $-277,00$ & 438,00 \\
\hline
\end{tabular}

Fonte: Elaborado pelo autor no programa SPSS versão 18 para Windows

A partir dos resultados apresentados na Tabela 9 observa-se, em um primeiro momento, que todos os grupos de estudo aqui avaliados apresentaram uma diferença positiva entre os valores de microdureza de superfície, identificando-se uma maior diferença entre esses valores (inicial e final) nas amostras de esmalte dentário quando comparado com os outros grupos. Por outro lado, a diferença de valores do grupo da região do corpo mandibular apresentou a menor diferença intergrupo dos valores de microdureza aqui obtidos. 
Tabela 10. Prova de homogeneidade dos grupos analisados através do teste de ANOVA

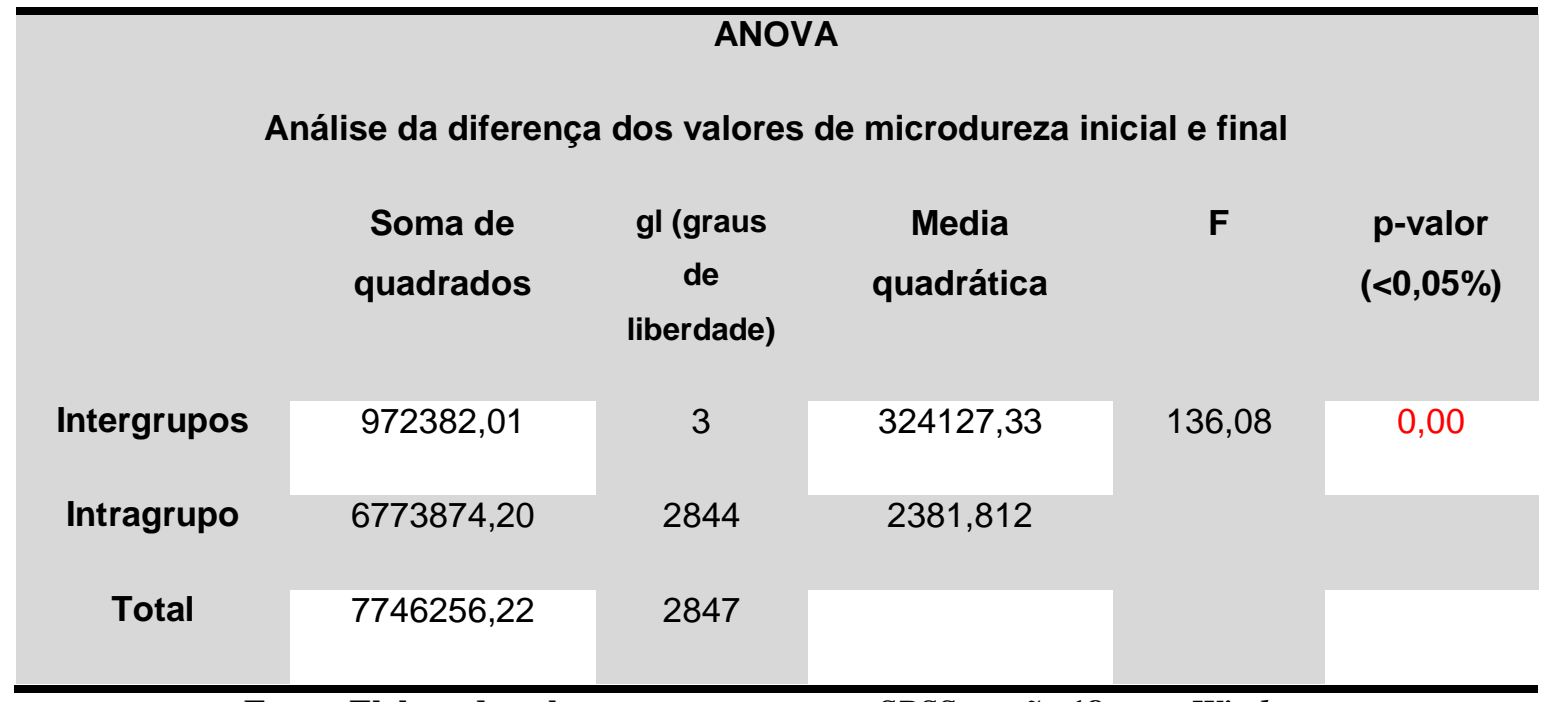

Fonte: Elaborado pelo autor no programa SPSS versão 18 para Windows

A partir dos resultados obtidos da Tabela 10, comprova-se que existe uma diferença estatisticamente significativa entre os grupos do estudo, a partir da diferença das médias dos valores iniciais e finais da microdureza de superfície. Consequentemente, o grau de acometimento dos tecidos duros submetidos à irradiação gama (esmalte dentário, dentina radicular, corpo mandibular e região do trígono retromolar) foi diferente para cada um dos grupos, ou seja, a radioterapia atingiu cada tecido de forma diferente, com um prejuízo maior em alguns grupos do que em outros. 


\section{Tabela 11. Teste estatístico Tukey para análise da diferença das médias da microdureza de superfície dos grupos em estudo}

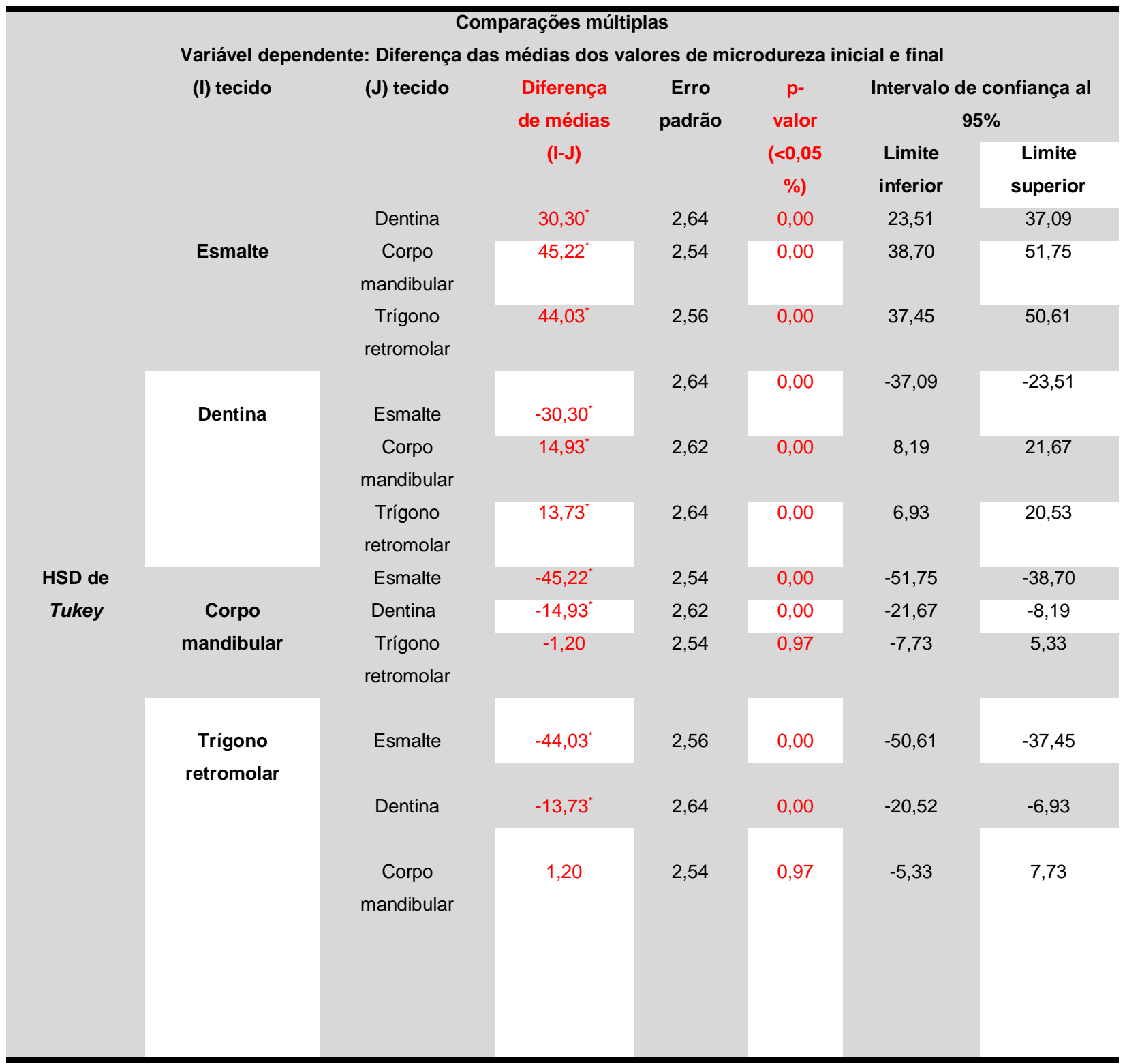

Fonte: Elaborado pelo autor no programa SPSS versão 18 para Windows

A Tabela 11 apresenta as comparações correspondentes às diferenças das médias dos valores iniciais e finais de microdureza de superfície dos grupos em estudo, os quais refletem um maior grau de diferença no grupo do esmalte dentário quando comparados aos outros grupos. A diferença acentua-se quando comparados os grupos de corpo mandibular e da 
região do trígono retromolar. No que diz respeito à dentina radicular existe uma diferença intergrupos significante quando comparados com todos os grupos, apresentando uma diferença negativa quando comparado com o grupo de esmalte dentário (devido a um maior acometimento deste grupo e, por conseguinte uma maior diminuição da dureza de superfície das amostras avaliadas). Por outro lado, para o caso das amostras de corpo mandibular e o trígono retromolar, a dentina apresentou uma diferença negativa, ou seja, houve uma maior perda de dureza de superfície na dentina radicular do que nos subgrupos mandibulares, resultando numa diferença estatisticamente significante. Finalmente, quando comparados os grupos de corpo mandibular e a região do trígono retromolar estabeleceu-se uma relação não estatisticamente significativa para a diferença das médias dos valores iniciais e finais da microdureza de superfície sugerindo que a irradiação gama acometeu ambos os tecidos em uma mesma magnitude, obtendo-se resultados próximos de dureza de superfície após a radioterapia.

A Figura 28 apresenta os valores da média das diferenças entre os valores de microdureza de superfície inicial e final dos grupos em estudo (esmalte dentário, dentina radicular, corpo mandibular e região do trígono retromolar) no qual observa-se que o grupo do esmalte obteve um maior valor da diferença entres as médias dos valores iniciais e finais de microdureza de superfície quando comparado com outros grupos. Salienta-se também que houve uma similaridade nos valores da média obtida para o grupo de corpo mandibular e região do trígono retromolar 
Figura 28. Média das diferenças dos valores de microdureza de superfície inicial e final dos grupos em estudo

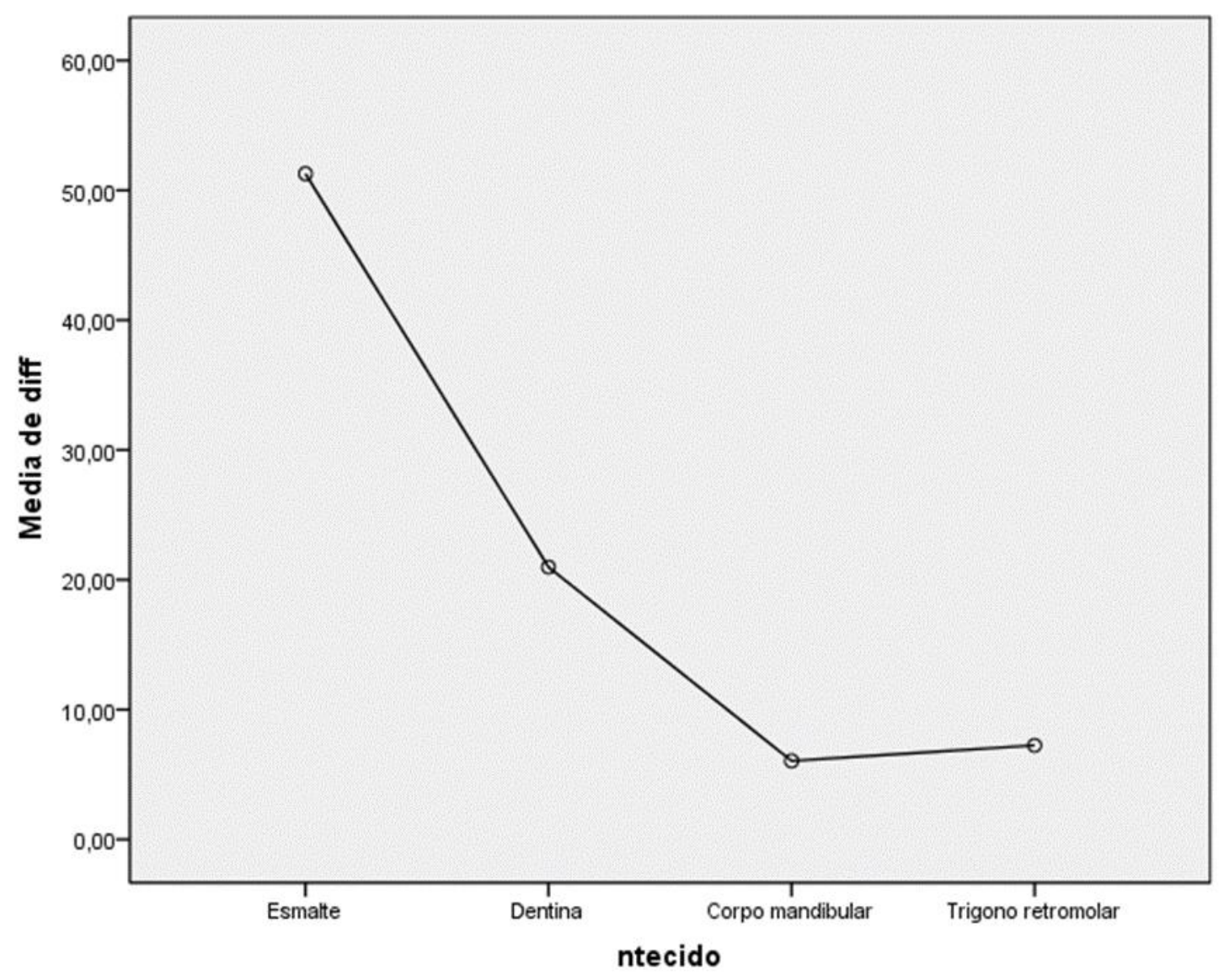

Fonte: Elaborado pelo autor no programa SPSS versão 18 para Windows

\section{2 ANÁLISES NA MICROSCOPIA ELETRÔNICA DE VARREDURA (MEV)}

A Figura 29, a seguir mostra as eletromicrografias obtidas no MEV, correspondente às análises do grupo controle e grupo irradiado das amostras de corpo mandibular e região do trígono retromolar com a finalidade de estabelecer-se uma análise morfológica comparativa de ambos os momentos (antes e após à irradiação gama). 
Figura 29. Amostra de corpo mandibular antes (lado esquerdo) e após a irradiação gama (lado direito) com uma magnificação de 4000x

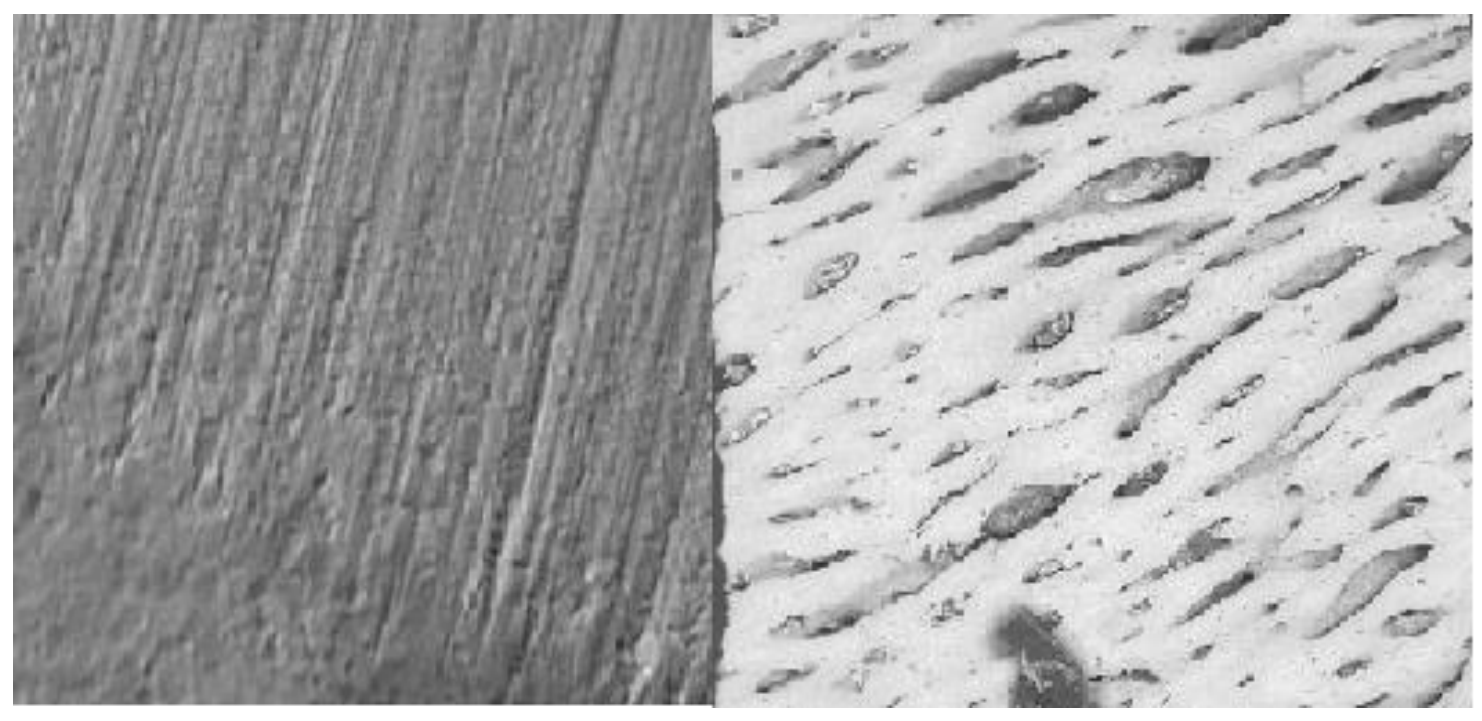

Fonte: Autor

A Figura 29 apresenta uma eletromicrografias comparativa entre a estrutura da amostra de corpo mandibular antes de ser submetida à irradiação gama e após polimento mecânico na politriz. Observa-se um osso compacto, de superfície lisa, de opacidade acentuada, o que confirma a sua alta densidade mineral e grau de compactação. Por outro lado, observam-se linhas verticais muito tênues que percorrem a superfície no total, sendo provavelmente criadas devido ao polimento realizado, porém, a integridade do tecido é absolutamente mostrada na imagem. Por outro lado, a eletromicrografias do lado esquerdo apresenta a amostra de corpo mandibular após ter recebido a dose total de $72 \mathrm{~Gy}$ de radiação gama. Observa-se uma superfície esburacada e completamente desestabilizada estruturalmente, com perda de continuidade e homogeneidade do tecido. Por outro lado, nos arredores da região central, identifica-se trincas e depressões, as quais espalham-se pela superfície toda, o que comprova, de fato, o efeito deletério da irradiação gama sobre este tecido, embora o corpo mandibular apresente uma maior densidade e maior tecido cortical, porém uma irrigação sanguínea e nutrição intercelular diminuída quando comparada com a região do trígono retromolar. Morfologicamente, esta região vê-se afetada na grande maioria de sua superfície. 
Figura 30. Amostra da região do trígono retromolar antes da irradiação gama (lado esquerdo) e após a irradiação gama (lado direito) com uma magnificação de 4000x

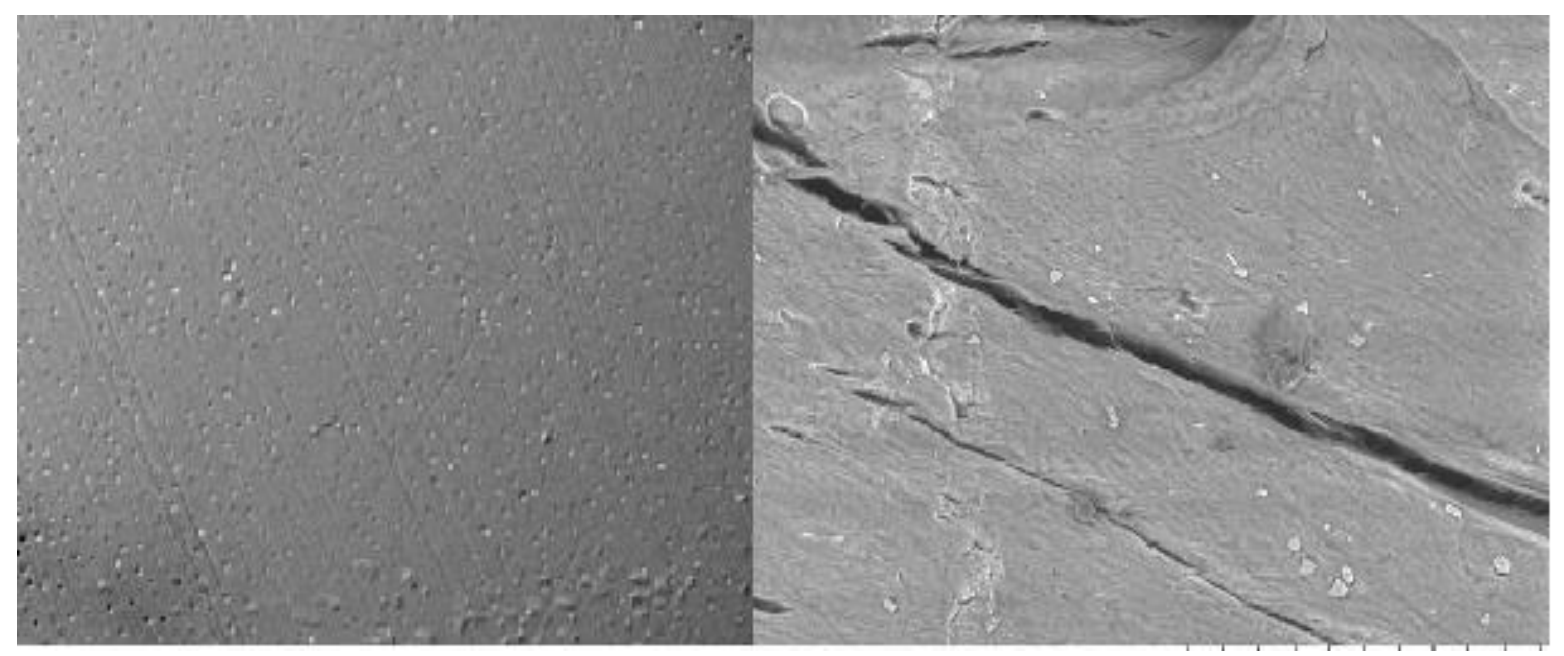

Fonte: Autor

A Figura 30 (eletromicrografia do lado esquerdo), representa uma eletromicrografia obtida da amostra da região do trígono retromolar antes da irradiação gama, após polimento mecânico, na qual pode observar-se uma superfície lisa e uniforme, correspondente a um tecido aparentemente saudável no nível macrorregional, analisada com uma magnificação de 4000x. A porosidade observada neste caso refere-se ao trabeculado e aos condutos haversianos presentes. No entanto, a eletromicrografia do lado direito representa a amostra da região do trígono retromolar após a dose total recebida de radiação gama (72Gy). A imagem mostra uma acentuada desorganização da superfície analisada, apresentando um trincamento de comprimento considerável, além de observar-se trincas menores ao redor da trinca maior, pelo qual considera-se que o efeito da radiação no local irradiado exerceu um maior efeito deletério em um determinado local quando comparado com outros locais da superfície. Por outro lado, a instabilidade gerada pela radiação gama conduz a uma destruição maior do tecido, conjuntamente com a perda da dureza de superfície. A região do trígono retromolar apresenta uma maior quantidade de osso trabeculado e menor compactação quando comparado com outras regiões da mandíbula, o que acarretará provavelmente uma maior incidência de ORN nesse local. 
As eletromicrografias a seguir representam uma amostra de esmalte dentário após a irradiação gama mostrada com diferentes aumentos nas quais observa-se uma clara desintegração e deterioração da superfície do esmalte, com presença de trincamentos e linhas de fratura ao redor da superfície central. A amostra foi submetida à irradiação gama com uma dose total de 72Gy. Na Figura 31, com uma magnificação de 500x, pode-se identificar uma superfície atingida pela radiação. Na Autor

Figura 32, com uma magnificação de 1000x observa-se, no modo da imagem topográfica, uma superfície rugosa, heterogênea com falta de continuidade no que diz respeito à textura. Posteriormente a uma maior magnificação de 2000x, Figura 33, conseguese distinguir um trincamento de maior comprimento ao nível da superfície, de forma irregular e esburacada, pelo fato da radiação gama ter alterado a integridade estrutural, inclusive observando-se fragmentos do tecido duro acometido. Finalmente, na Figura 34, uma acentuada linha de fratura é observada na superfície, de comprimento considerável, destacada numa magnificação de 4000x.

Figura 31. Amostra de esmalte dentário após irradiação gama (500x)

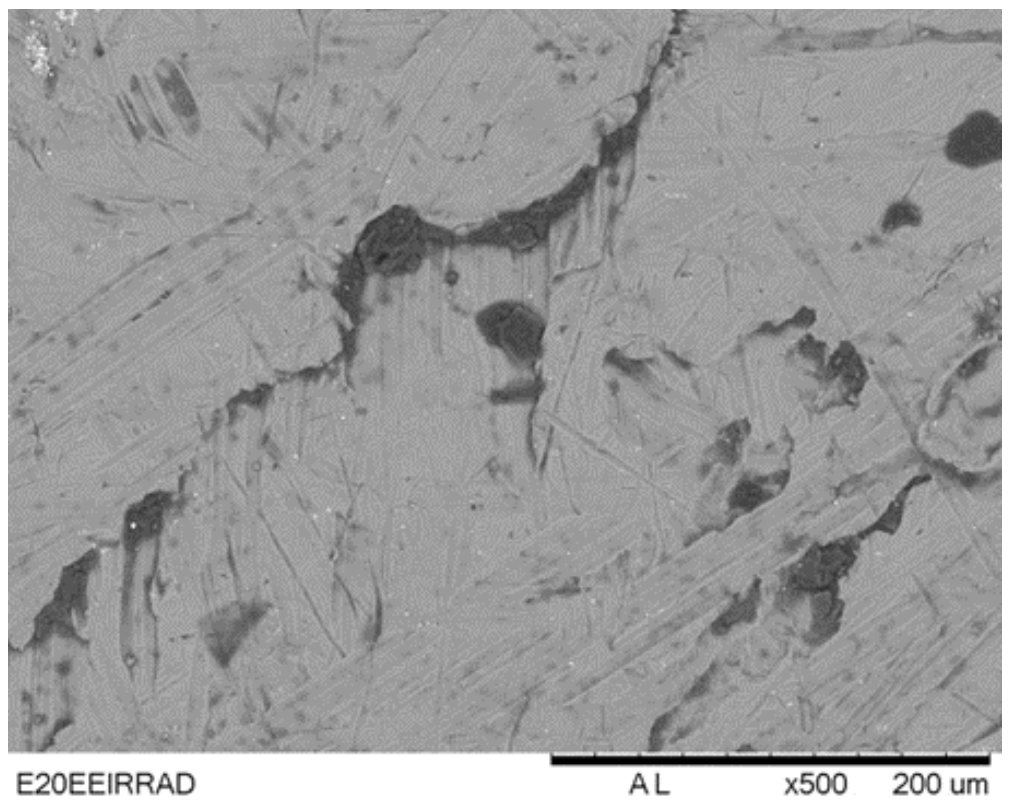

Fonte: Autor 
Figura 32. Amostra de esmalte dentário após irradiação gama (1000x)

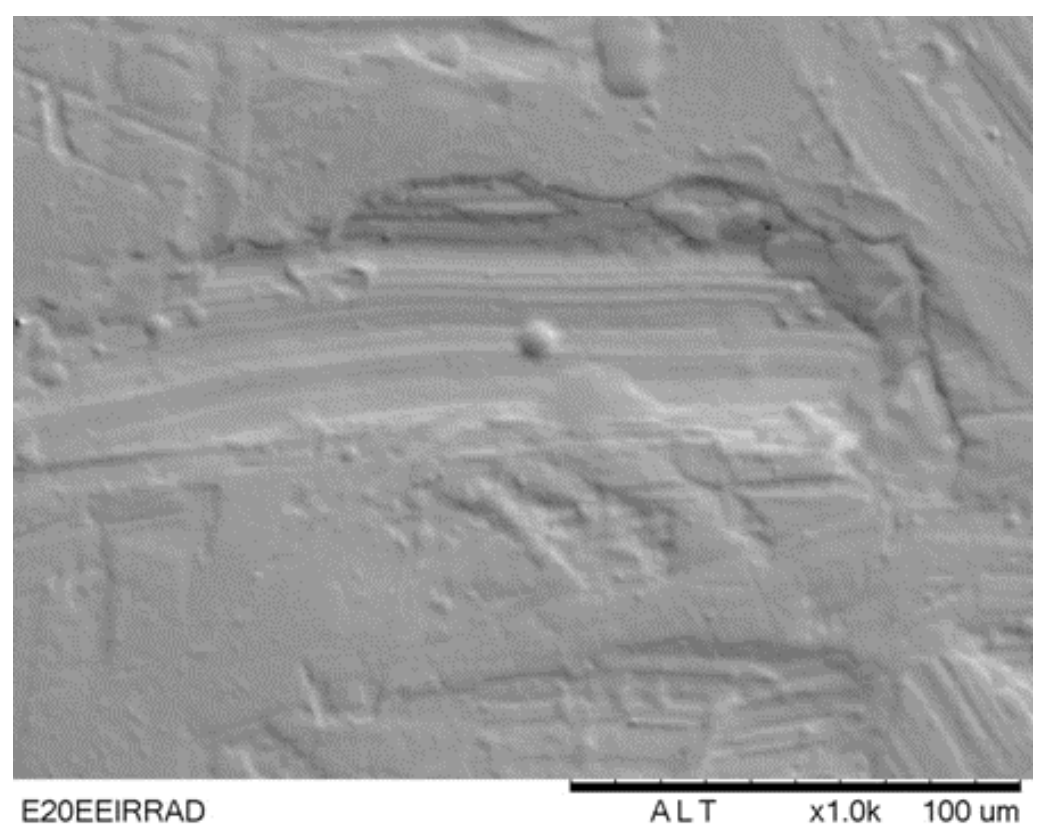

Fonte: Autor

Figura 33. Amostra de esmalte dentário após irradiação gama (2000x)

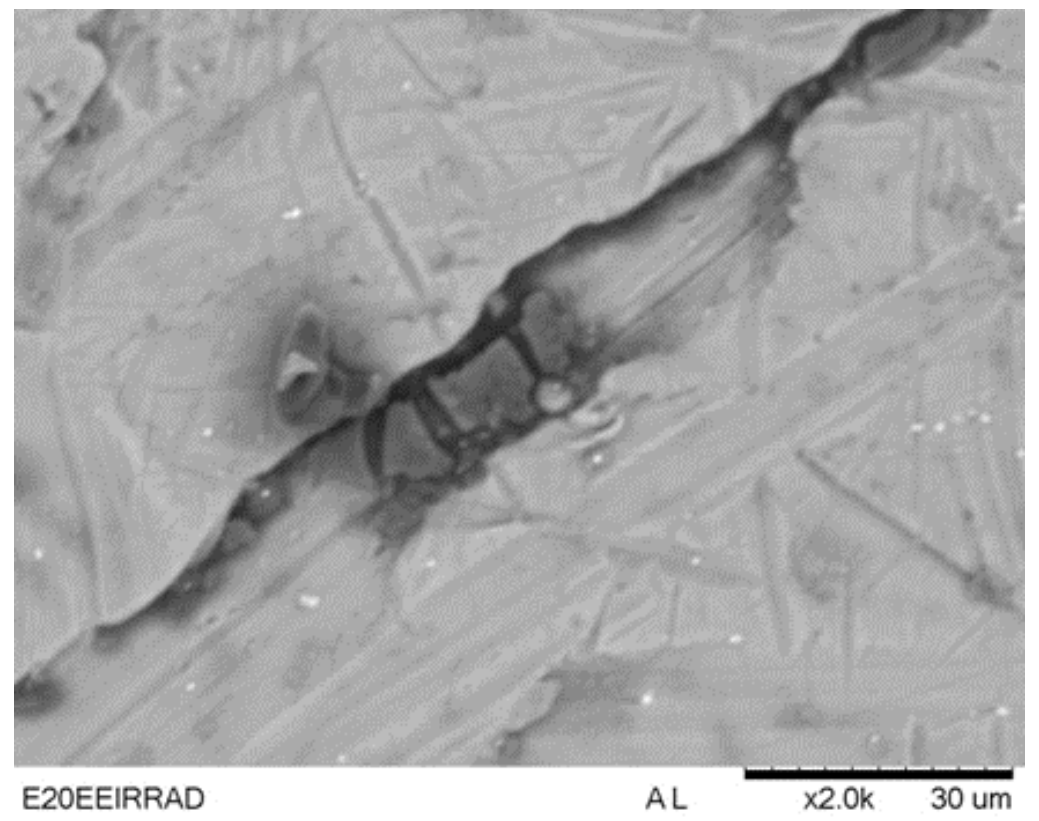

Fonte: Autor 
Figura 34. Amostra de esmalte dentário após irradiação gama (4000x)

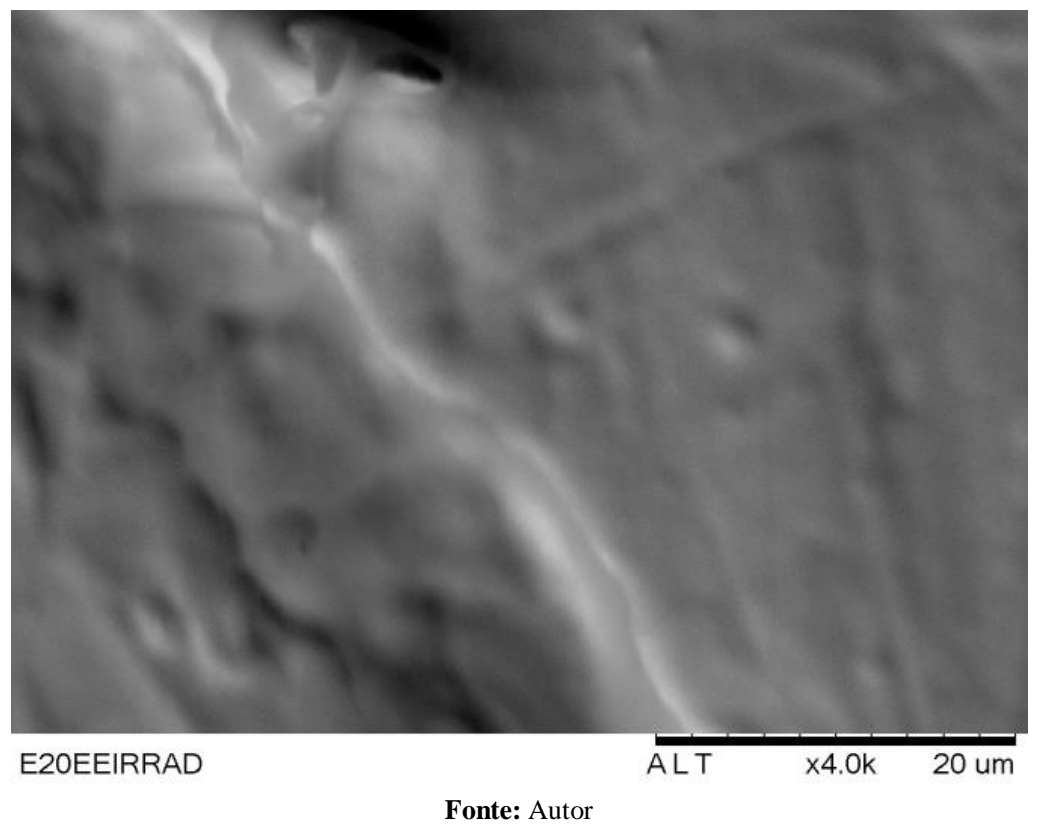

As figuras a seguir apresentam eletromicrografias da amostra de dentina radicular após a irradiação gama. Na Figura 35, com um aumento de 500x observa-se um trincamento na região central da amostra, de comprimento considerável, o qual demonstra o acometimento da superfície em estudo (modo da imagem composicional). Na Figura 36 observa-se no modo de imagem topográfica, o trincamento ou linha de fratura no eixo longitudinal da amostra, representando-se o grau de acometimento pela radiação gama e a dose total empregada (72Gy) com um maior aumento de 1000x. No que diz respeito à Figura 37, com um aumento de 2000x e em outro ponto da superfície da amostra de dentina, destacase outra linha de fratura, com deslocamento leve das bordas e perda da continuidade do tecido mineralizado, o qual novamente apresenta um acometimento em outro ângulo da superfície do bloco de dentina analisado, obtendo-se maiores detalhes. Finalmente, na Figura 38, observa-se ao longo do eixo principal da amostra um trincamento que se estende na maior parte da superfície da amostra, visualizando-se no modo de imagem topográfica e detectandose claramente o efeito deletério causado no bloco irradiado, com uma lente de aumento 4000x. 
Figura 35. Amostra de dentina radicular após irradiação gama (500x)

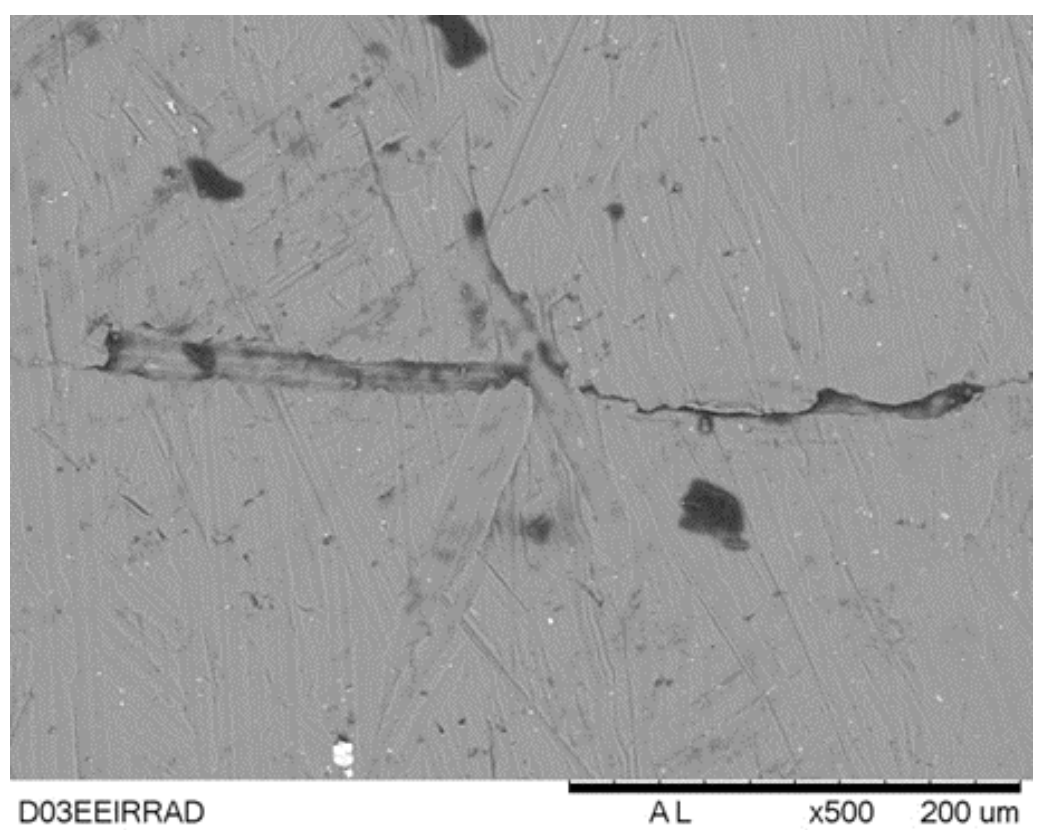

Fonte: Autor

Figura 36. Amostra de dentina radicular após irradiação gama (1000x)

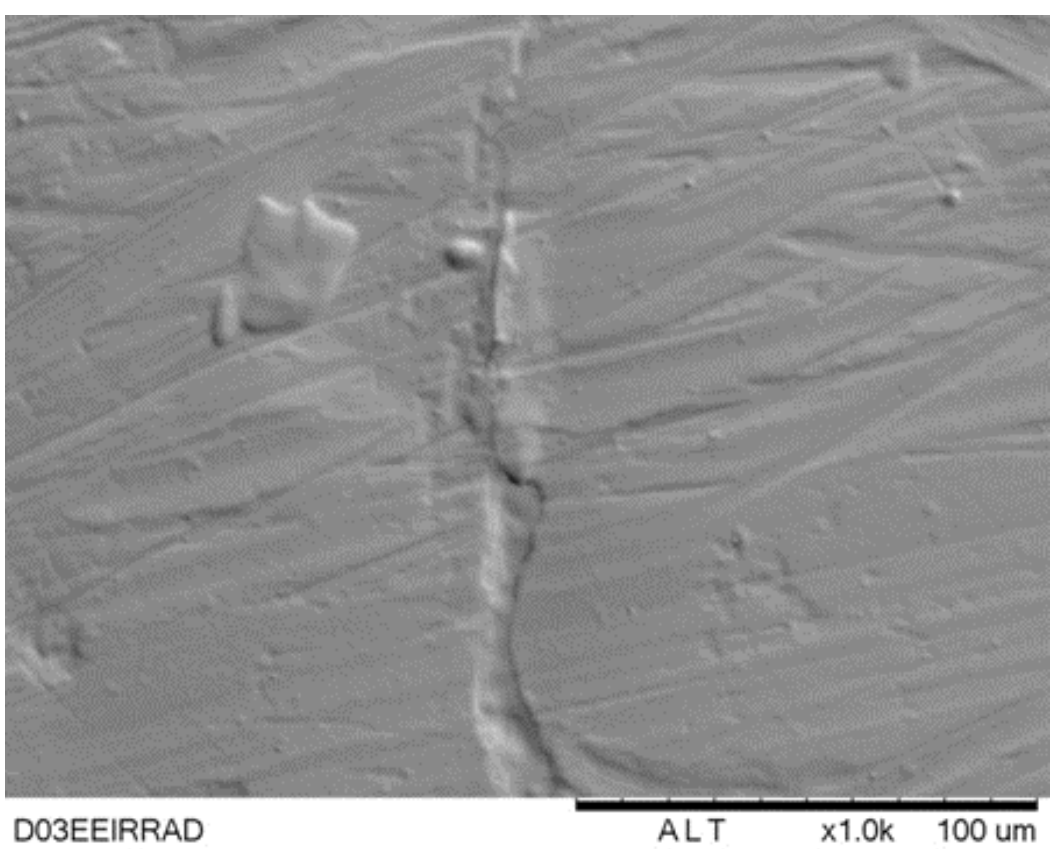

Fonte: Autor 
Figura 37. Amostra de dentina radicular após irradiação gama (2000x)

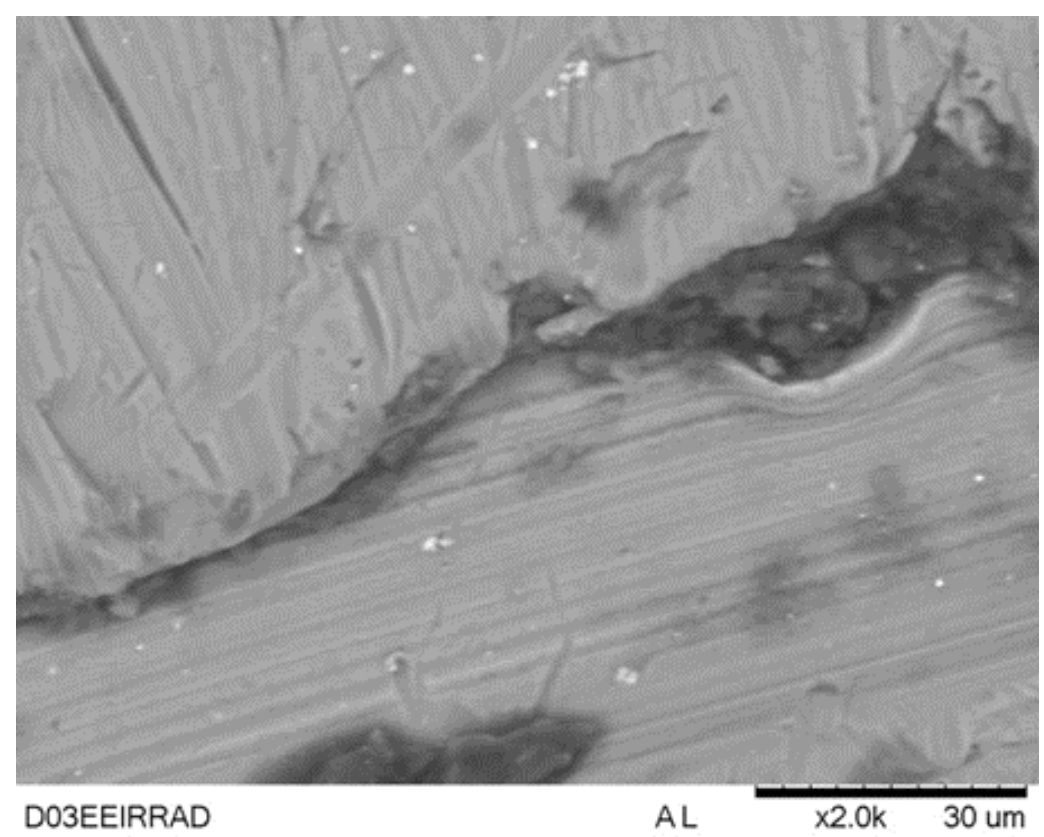

Fonte: Autor

Figura 38. Amostra de dentina radicular após irradiação gama (4000x)

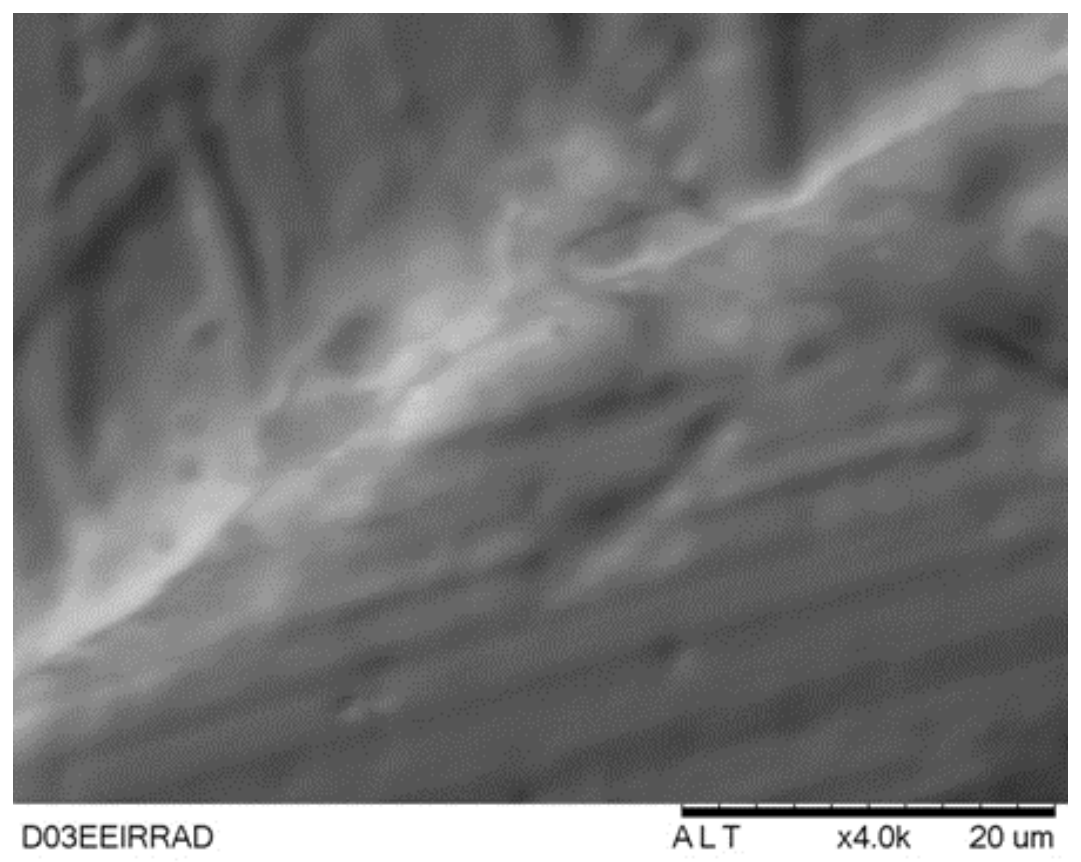

Fonte: Autor 
As eletromicrografias seguintes, Figura 39 a Figura 42, apresentam outra amostra de corpo mandibular. Elas mostram os efeitos deletérios causados pela irradiação gama na superfície do tecido duro em diferentes aumentos. Apresentam-se os trincamentos, perfurações e linhas de fraturas das geradas após a irradiação, distinguindo-se os diferentes graus de acometimento em cada aumento apresentado, observando-se deslocamentos dos fragmentos, quanto a perda de continuidade do tecido no que diz à uma superfície lisa, plana e sem áreas esburacadas ou perfuradas. A última eletromicrografia, Figura 42, apresenta uma fragmentação progressiva em torno de um núcleo central, com separação das formas, com aspecto de uma fratura cominutiva da superfície da amostra de corpo mandibular. Além disso, é peculiaridade desta amostra diferentes tipos de trincamentos com profundidade reduzida e uma tênue linha de fratura central.

Figura 39. Amostra de corpo mandibular após irradiação gama (500x)

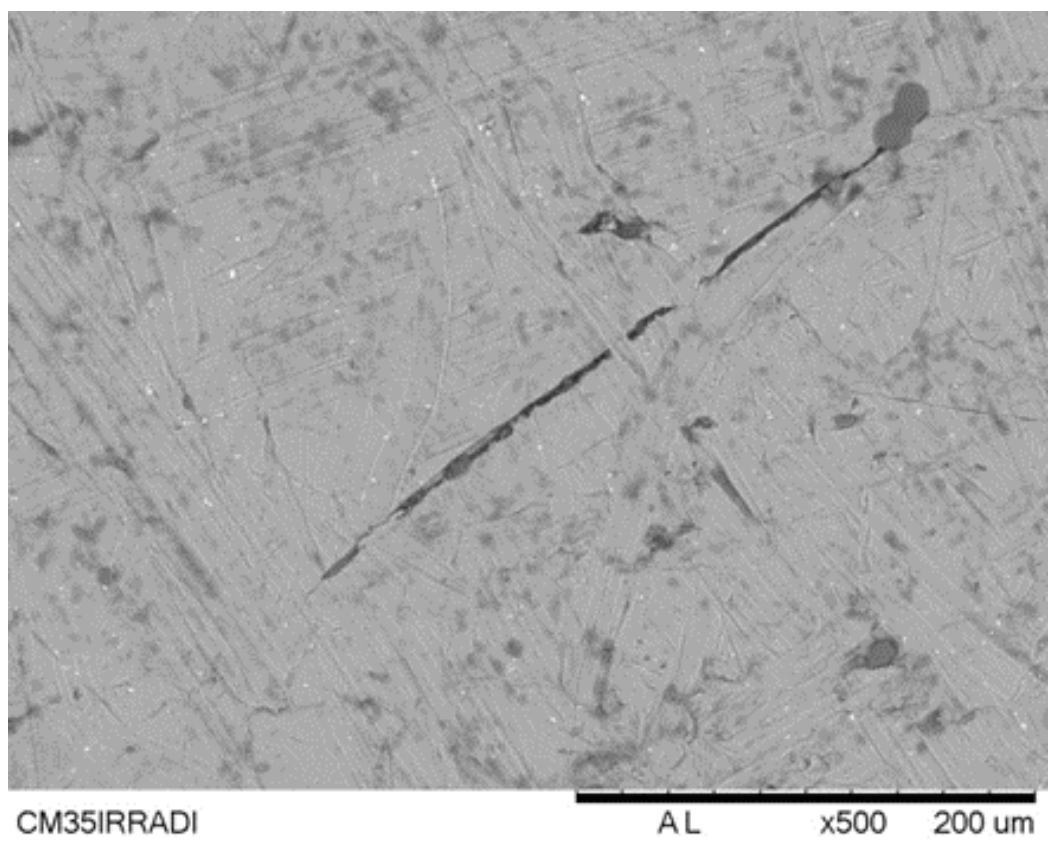

Fonte: Autor 
Figura 40. Amostra de corpo mandibular após irradiação gama (1000x)

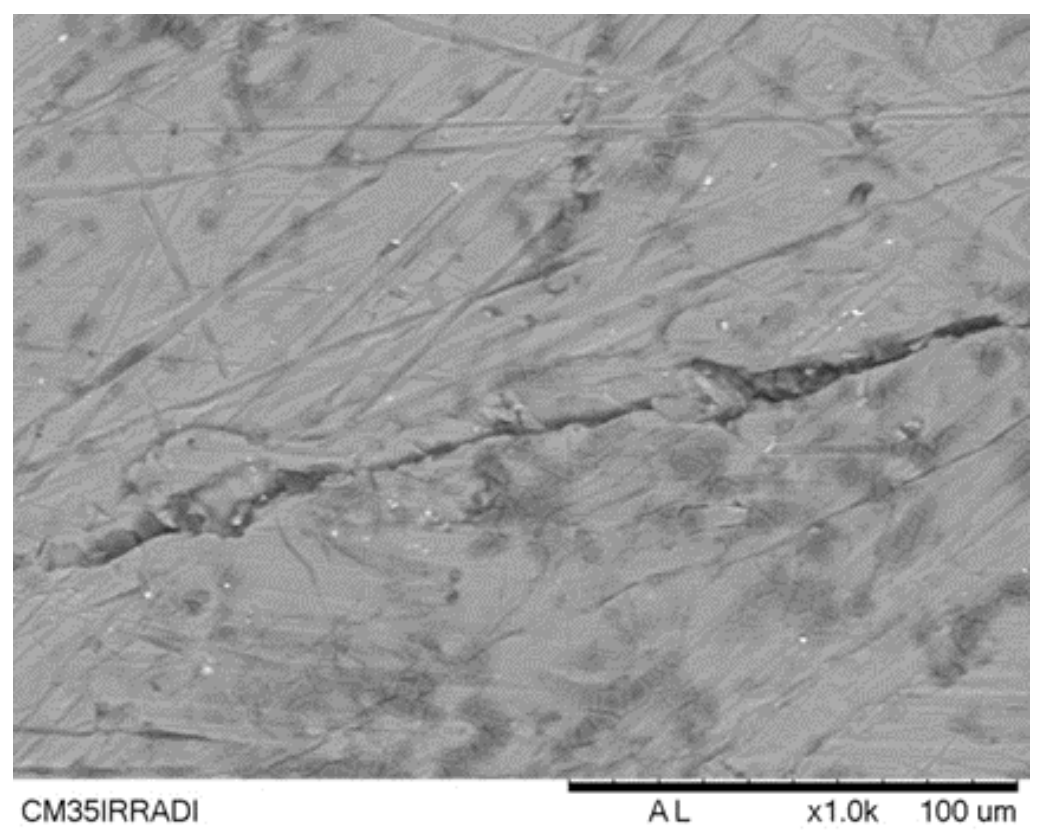

Fonte: Autor

Figura 41. Amostra de corpo mandibular após irradiação gama (2000x)

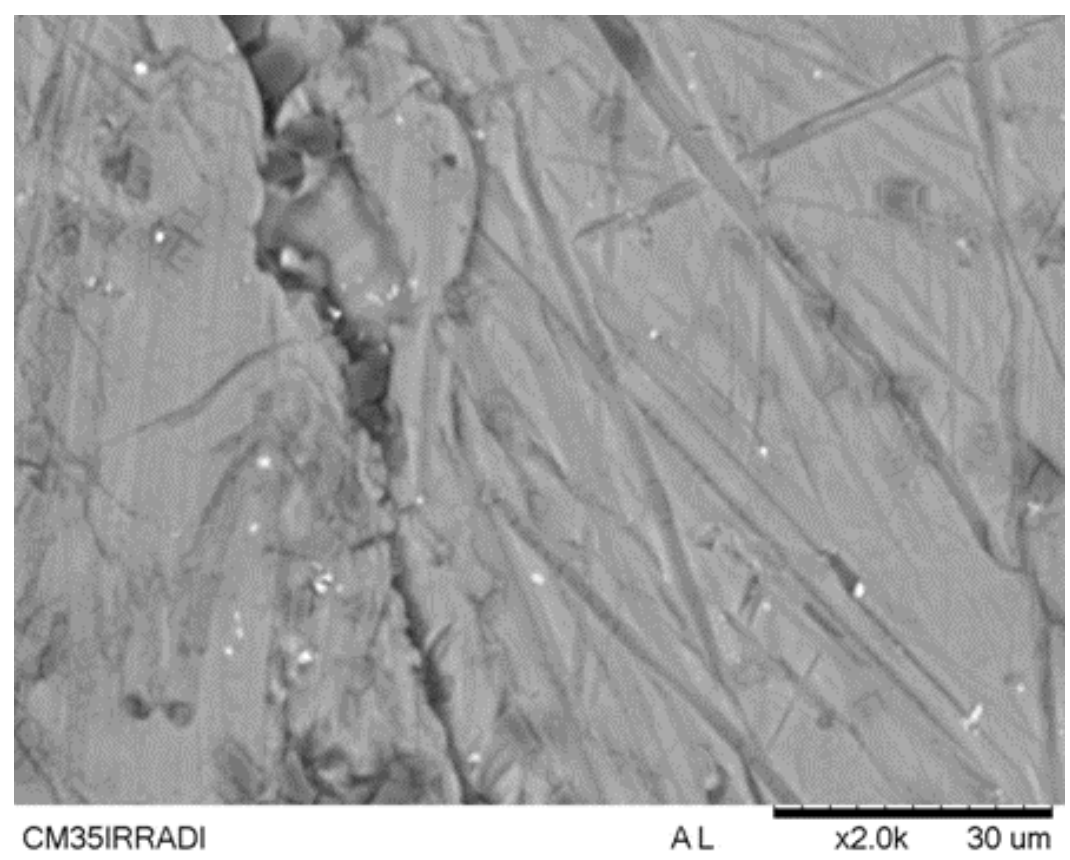

Fonte: Autor 
Figura 42. Amostra de corpo mandibular após irradiação gama (4000x)

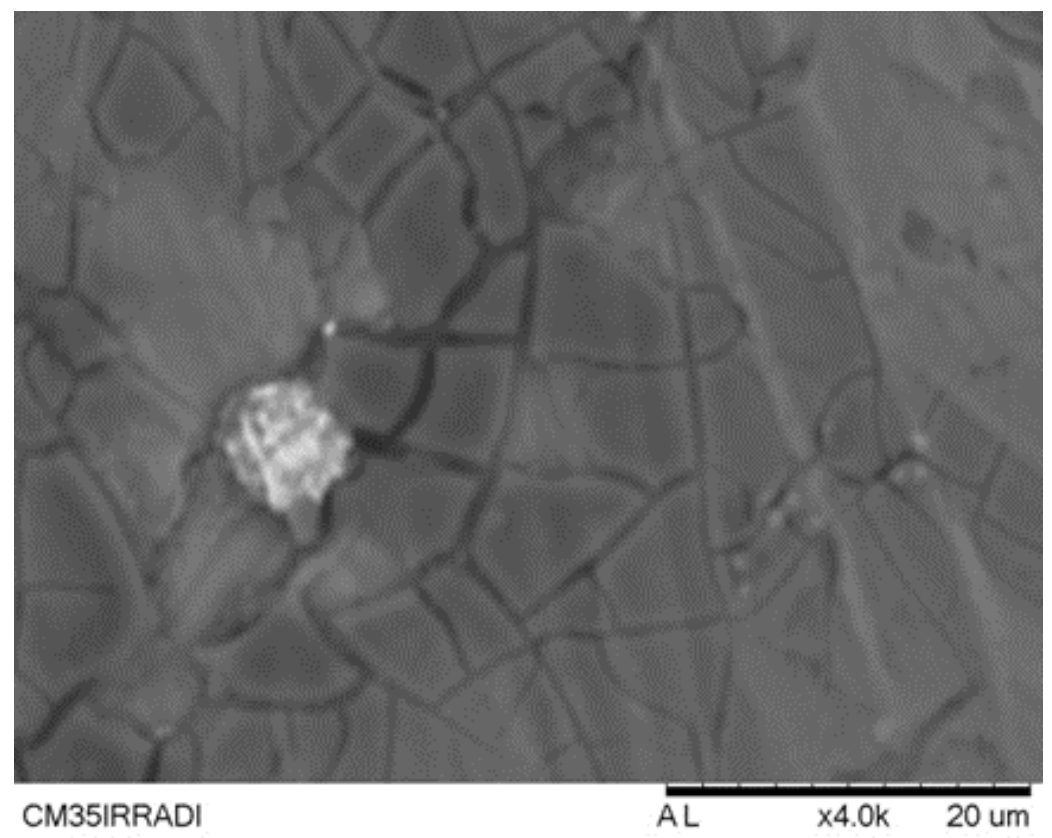

Fonte: Autor

As eletromicrografias, Figura 43 a Figura 46, apresentam imagens da amostra de esmalte dentário após a irradiação gama, nas quais observam-se as indentações realizadas após a radioterapia para cálculo de valor Knoop e obtenção da microdureza de superfície final do tecido. Estas indentações foram realizadas paralelas às iniciais separadas com uma distância de $200 \mu \mathrm{m}$ entre cada coluna. As eletromicrografias mostram as indentações em diferentes aumentos (300x, 1000x, 4000x e 5000x). Salientam-se as variações morfológicas observadas em cada imagem da superfície da amostra de esmalte pela ação exercida da radiação gama. 
Figura 43. Amostra de esmalte dentário após irradiação gama (300x)

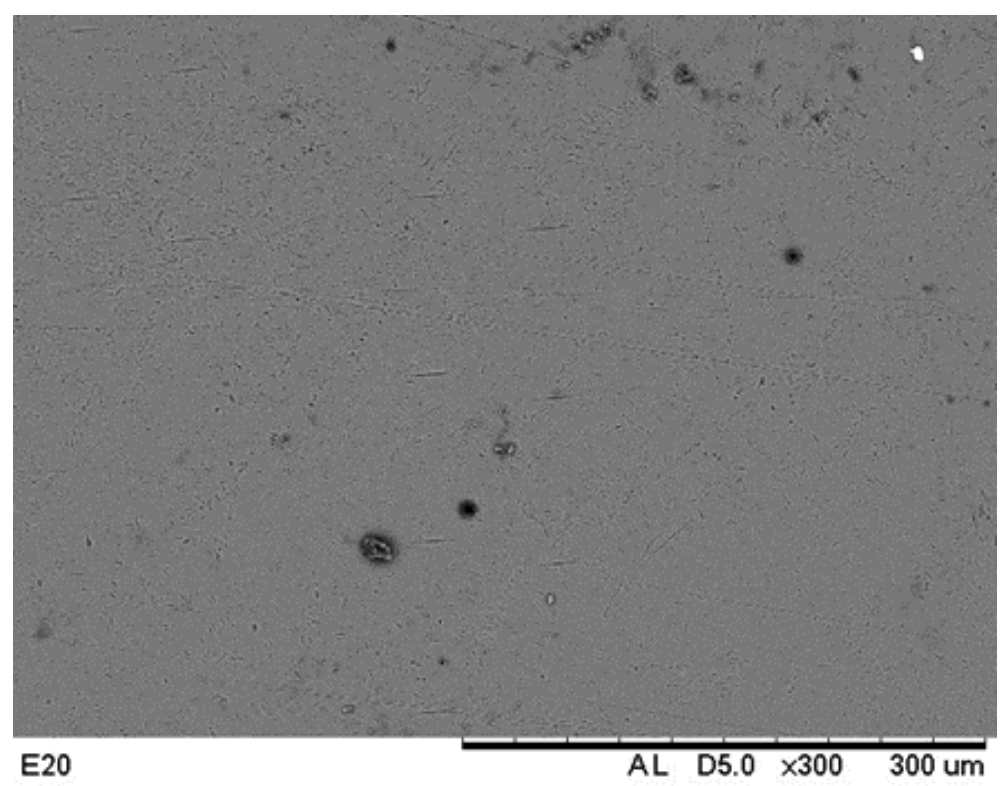

Fonte: Autor

Figura 44. Amostra de esmalte dentário após irradiação gama (1000x)

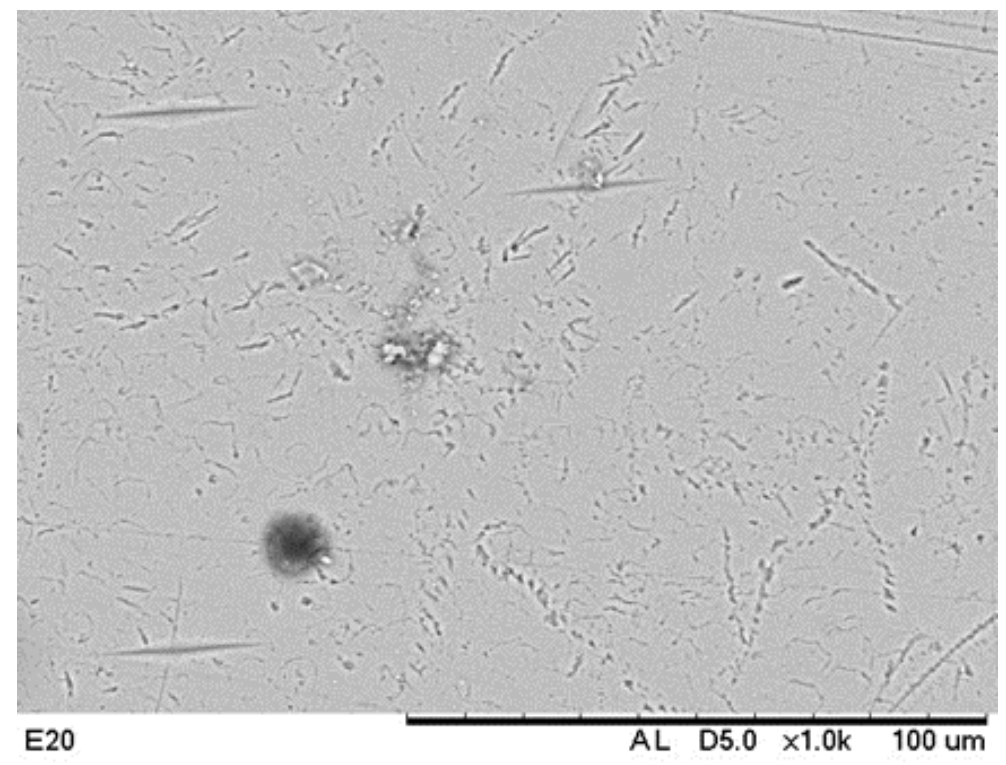

Fonte: Autor 
Figura 45. Amostra de esmalte dentário após irradiação gama (4000x)

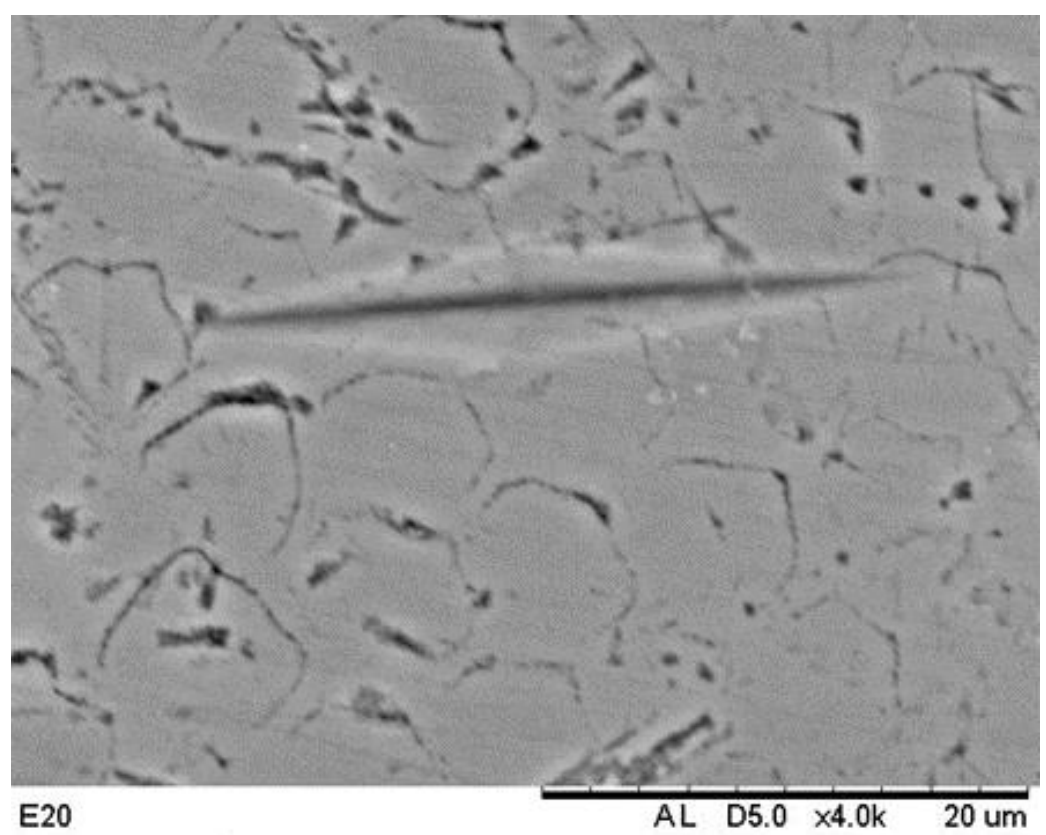

Fonte: Autor

Figura 46. Amostra de esmalte dentário após irradiação gama (5000x)

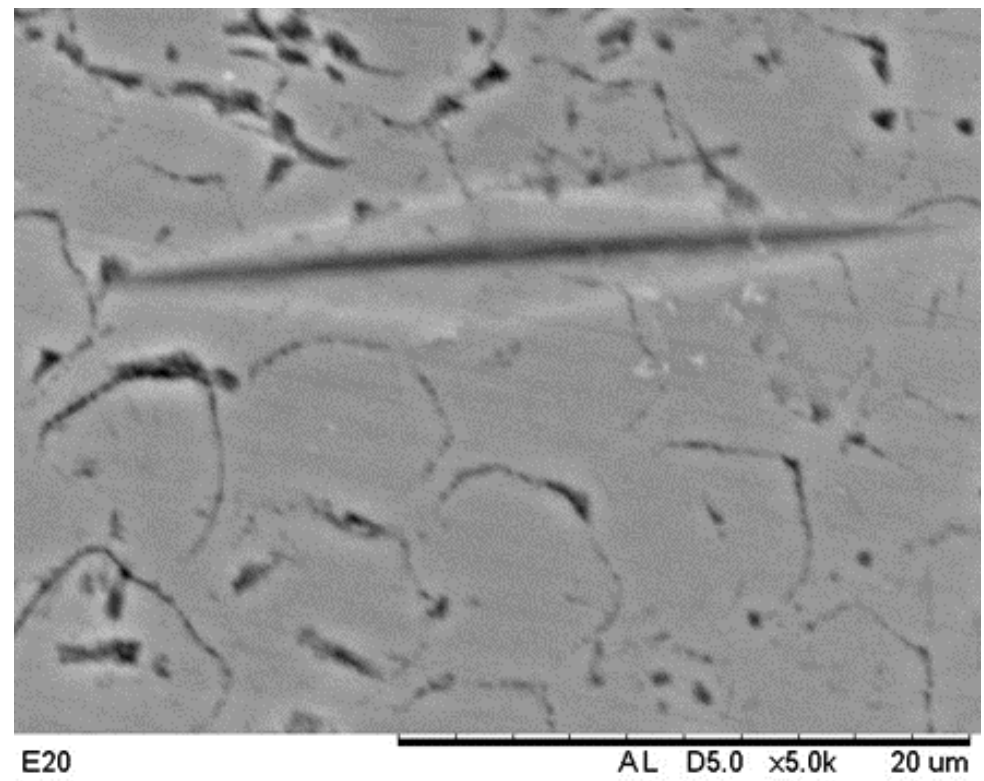

Fonte: Autor 
As figuras, Figura 47 a Figura 50, apresentam as eletromicrografias de outra amostra de dentina radicular após a irradiação gama (72Gy), as quais apresentam as indentações realizadas paralelamente às iniciais. As eletromicrografias, em diferentes aumentos, apresentam o comprimento da indentação final. A indentação final quando comparada com a indentação inicial apresenta um maior comprimento (Figura 49 e Figura 50), pelo qual, determina-se uma perda de conteúdo mineral na superfície e uma maior penetração do indentador Knoop na superfície, além da perda de dureza e uma predisposição à fratura, pela diminuição na resistência mecânica da amostra analisada.

Figura 47. Amostra de dentina radicular após irradiação gama (300x)

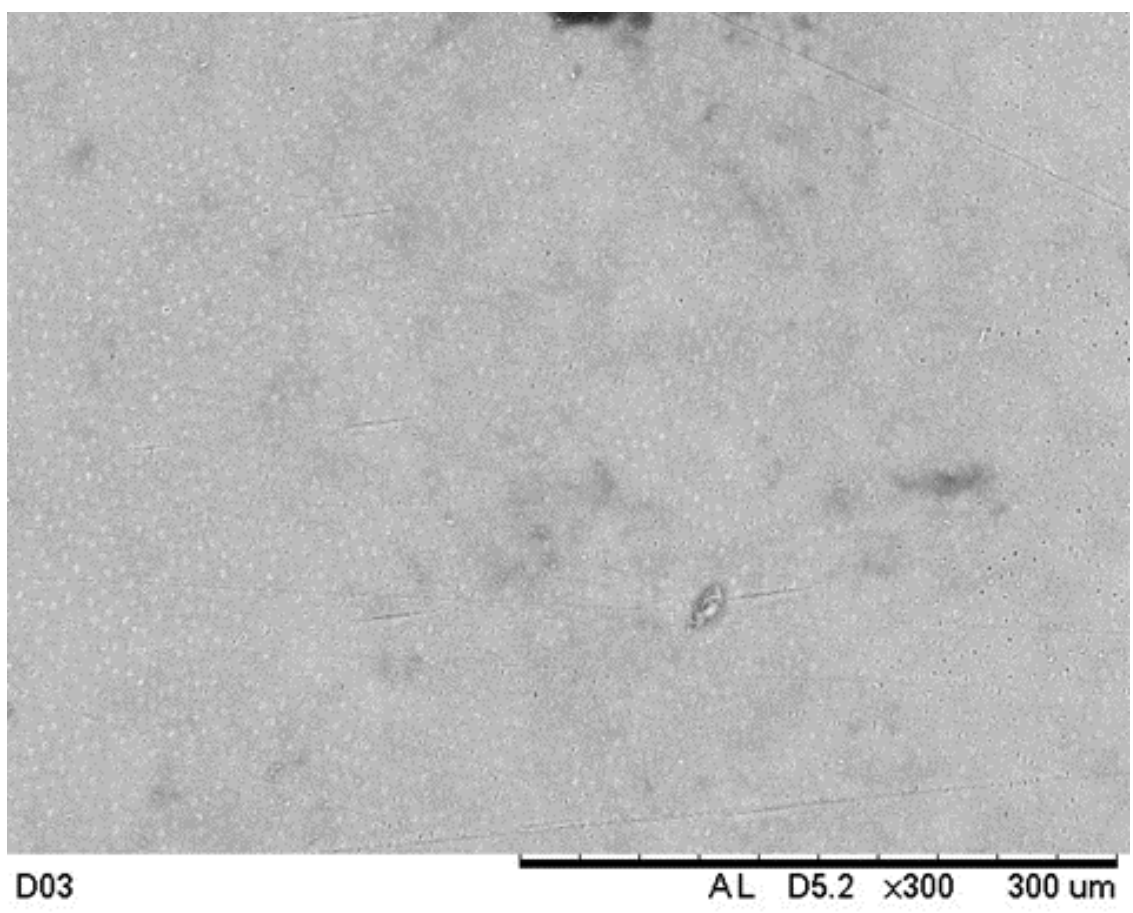

Fonte: Autor 
Figura 48. Amostra de dentina radicular após irradiação gama (1000x)

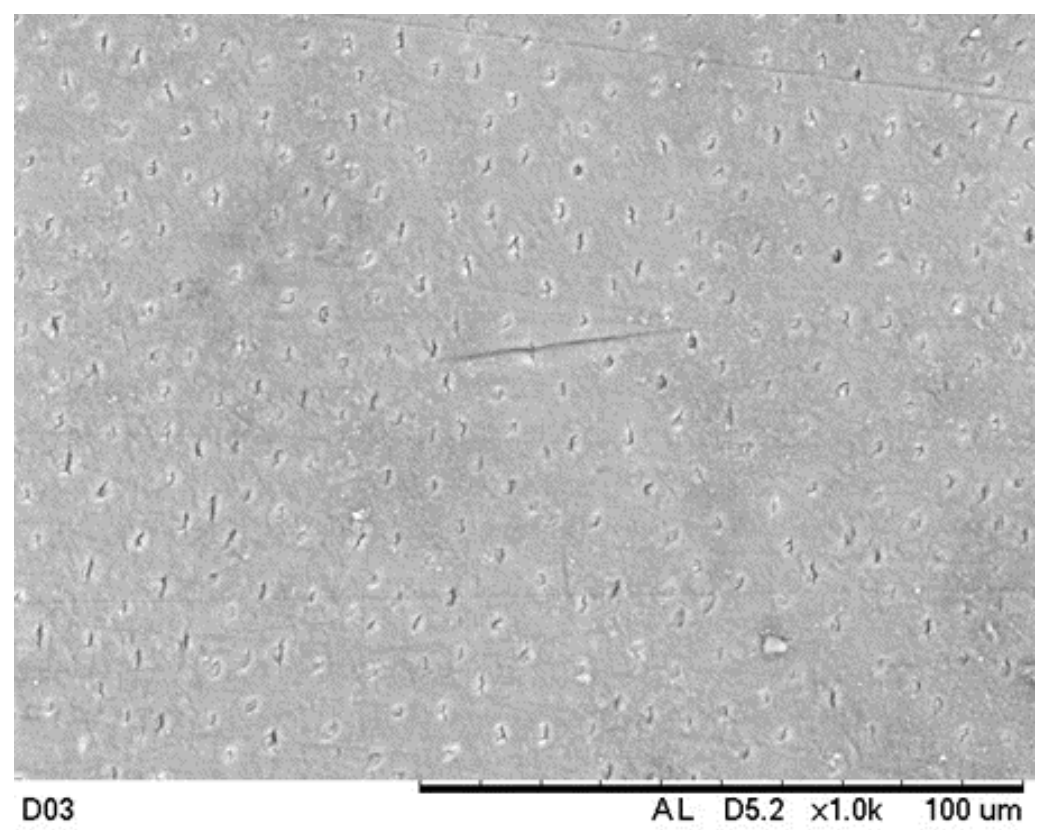

Fonte: Autor

Figura 49. Amostra de dentina radicular após irradiação gama (4000x)

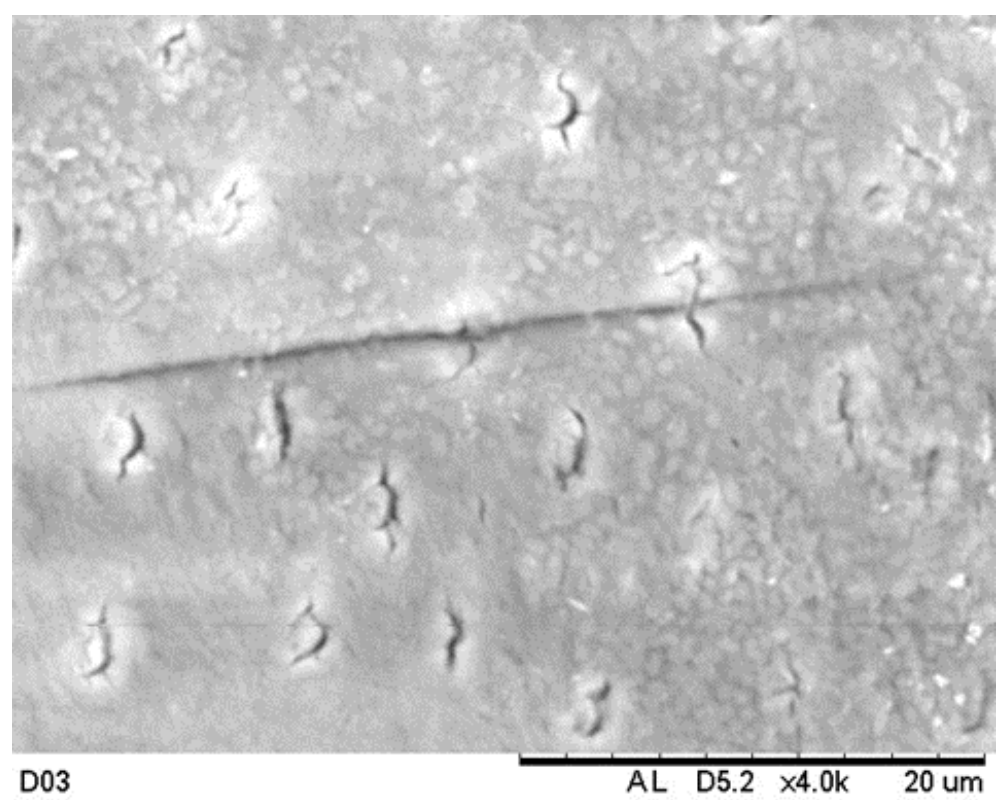

Fonte: Autor 
Figura 50. Amostra de dentina radicular após irradiação gama (5000x)

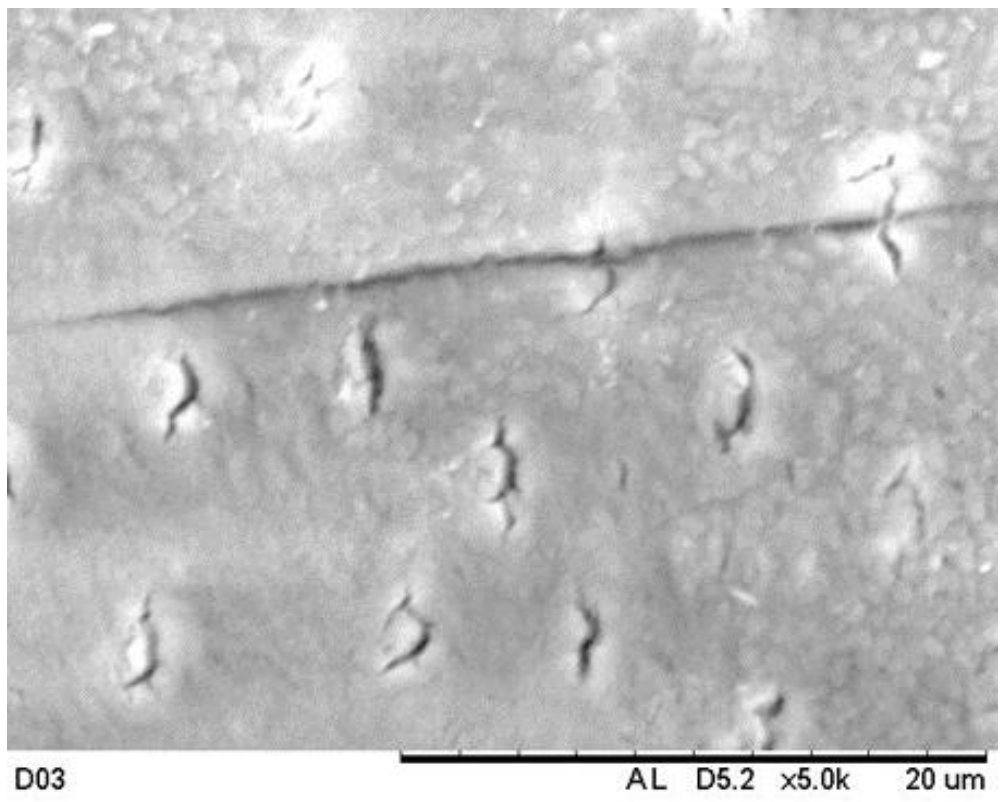

Fonte: Autor

5. 3 ANÁLISES POR ESPECTROSCOPIA NO INFRAVERMELHO POR TRANSFORMADA DE FOURIER - TÉCNICA DE REFLEXÃO TOTAL ATENUADA (ATR - FTIR)

A partir dos espectros obtidos pela transformada de Fourier após a aplicação da técnica de reflexão total atenuada (ATR), realizou-se a análise espectral das bandas obtidas na região do infravermelho médio, as quais representam a absorção dos compostos orgânicos e inorgânicos que absorveram a referida radiação nessa faixa espectral. Como anteriormente descrito, analisou-se o espectro das amostras do grupo denominado controle (antes da irradiação) e do grupo experimental (após a irradiação gama).

A Figura 51 apresenta e estabelece uma comparação entre os espectros das amostras de esmalte dentário, um correspondente à amostra do grupo controle (E69REF) e o outro à amostra submetida à irradiação gama (E07E1), com uma dose total de 72Gy. Observa- se, de modo geral um comportamento diferente entre as bandas obtidas em cada espectro no que diz respeito aos picos de absorção, intensidade, profundidade e deslocamento das mesmas, o 
que evidencia que a amostra tratada sofreu uma alteração bioquímica importante. Por outro lado, o aparecimento de novas bandas de absorção no espectro da amostra irradiada E07E1 supõe uma modificação estrutural e composicional do esmalte dentário quando submetido a uma dose de $72 \mathrm{~Gy}$ de radiação gama.

Figura 51. Espectroscopia por absorção no infravermelho médio da amostra controle e irradiada de esmalte dentário

Esmalte

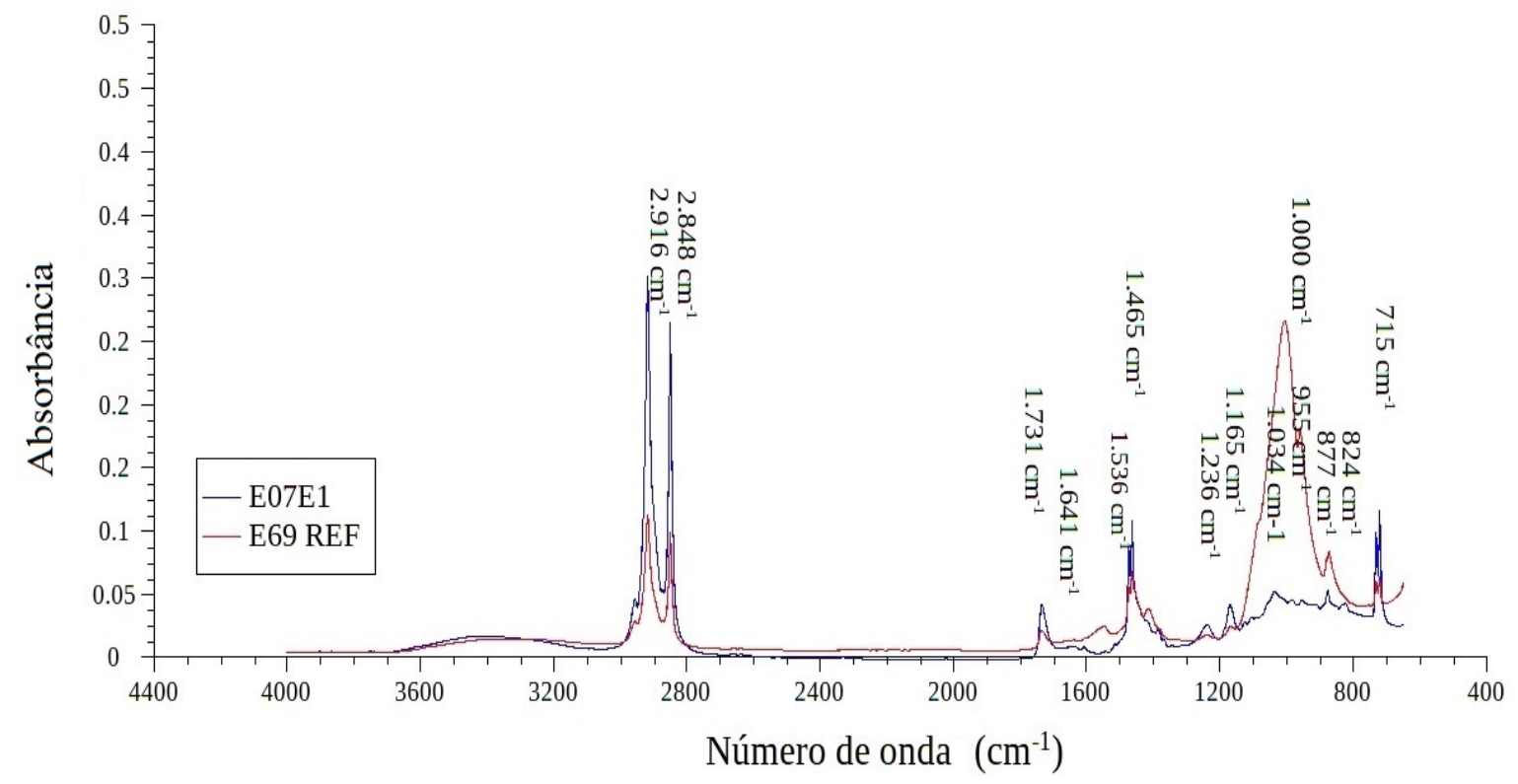

Fonte: Elaborado pelo autor no programa Labplot, Origin, para Linux

A seguir apresentam-se os compostos orgânicos e inorgânicos absorvidos correspondentes aos diferentes picos de absorção obtidos no espectro da amostra tratada (E07E1):

$\mathbf{3 . 4 2 5} \mathbf{~ c m}^{-1}$ : apresenta- se uma deformação axial da ligação O-H ou N-H livre;

$2.916 \mathrm{~cm}^{-1}$ : neste pico de absorção apresenta-se uma deformação axial assimétrica da ligação C-H (grupo metileno de hidrocarboneto);

$\mathbf{2 . 8 4 8} \mathbf{~ c m}^{-1}$ : neste caso apresenta-se uma deformação axial assimétrica da ligação C-H (grupo metileno de hidrocarboneto); 
$1.731 \mathbf{~ c m}^{-1}$ : neste pico de absorção apresenta-se uma deformação axial da ligação O-C--C (grupo peróxido);

$1.536 \mathrm{~cm}^{-1}$ : neste pico de absorção apresenta-se uma deformação angular da ligação N-H (amida II);

$1.465 \mathrm{~cm}^{-1}$ : apresenta-se uma deformação angular da ligação $\mathrm{O}-\mathrm{H}$ (proveniente de ácido carboxílico);

$1.236 \mathbf{~ c m}^{-1}$ : neste pico de absorção apresenta-se uma deformação angular da ligação N-H (amida III);

$1.165 \mathbf{~ c m}^{-1}$ : o pico de absorção apresenta uma deformação axial assimétrica da ligação C-OC (grupo éter);

$1.000 \mathrm{~cm}^{-1}$ : apresenta-se a absorção do grupo fosfato $\mathrm{PO}_{4}{ }^{3-}$ (matriz inorgânica);

$873 \mathrm{~cm}^{-1}$ : apresenta-se uma absorção do grupo fosfato $\mathrm{PO}_{4}{ }^{3-}$ (matriz inorgânica)

$715 \mathbf{~ c m}^{-1}$ : apresenta-se uma deformação angular fora do plano do grupo O-H ligado por pontes de hidrogênio.

A Figura 52 apresenta os espectros por absorbância das amostras de dentina radicular antes da irradiação gama, ambos os espectros superpostos nos quais observa-se um mesmo comportamento das bandas no que diz respeito aos compostos químicos, que absorveram a radiação infravermelha, determinado por cada pico da banda. A amostra controle D81REF apresenta um espectro de maior intensidade de absorção quando comparado com o espectro da outra amostra controle D52REF. 
Figura 52. Espectroscopia por absorção no infravermelho médio das amostras controle de dentina radicular

Dentina radicular

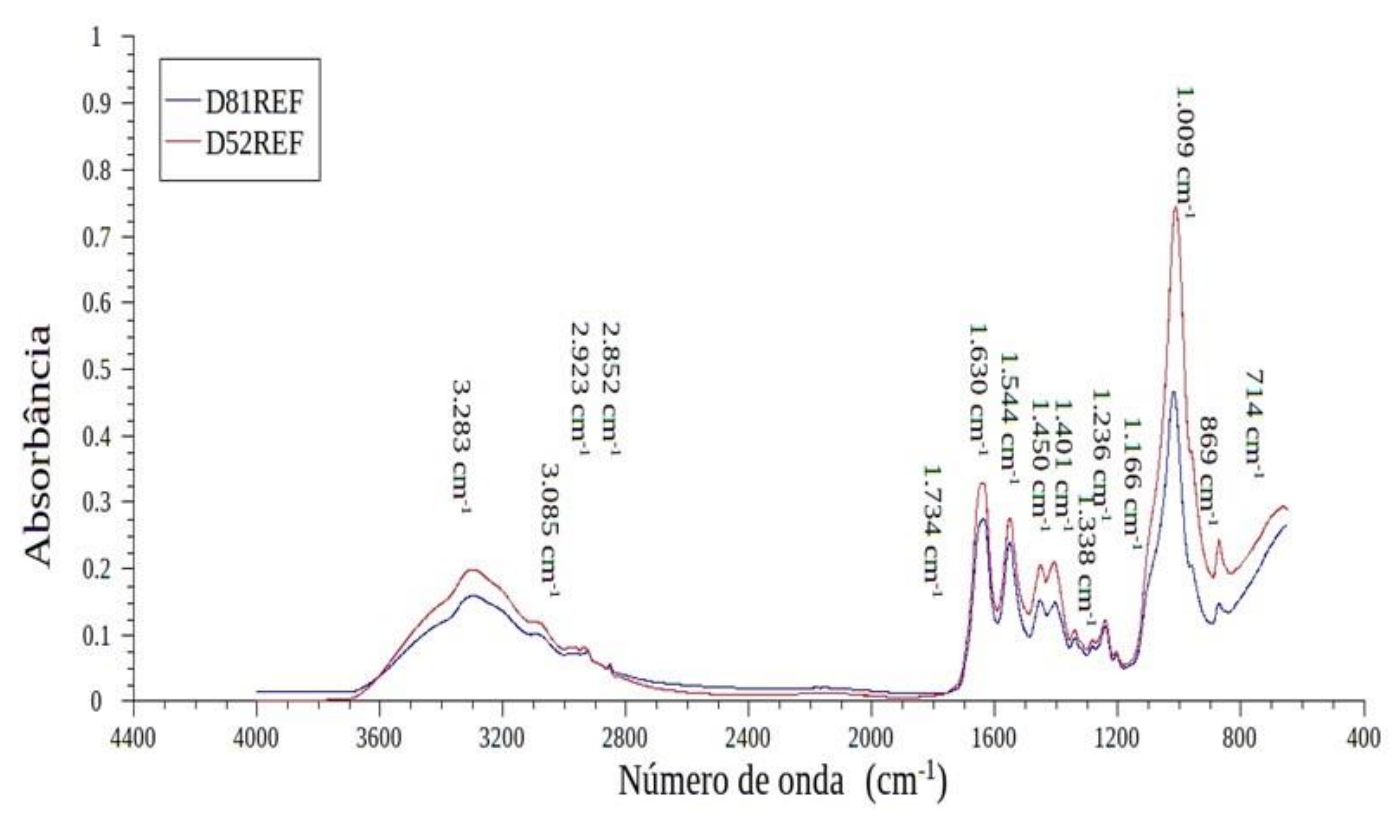

Fonte: Elaborado pelo autor no programa Labplot; Origin para Linux

Os compostos pertencentes a cada pico de absorção das bandas são apresentados a seguir:

Amostra D81REF:

$3.283 \mathrm{~cm}^{-1}$ : apresenta-se uma deformação axial da ligação O-H;

$3.085 \mathrm{~cm}^{-1}$ : apresenta-se uma deformação axial C-H (hidrocarboneto);

$2.923 \mathrm{~cm}^{-1}$ : apresenta-se uma deformação axial assimétrica da ligação C-H (grupo metileno de hidrocarboneto);

$2.852 \mathbf{~ c m}^{-1}$ : apresenta-se uma deformação axial simétrica da ligação C-H (grupo metileno de hidrocarboneto);

$1.630 \mathbf{~ c m}^{-1}$ : apresenta-se uma deformação angular da ligação N-H (amida I);

1.544 cm$^{-1}$ : apresenta-se uma deformação angular da ligação N-H (amida II); 
$1.450 \mathbf{~ c m}^{-1}$ : apresenta-se uma deformação angular da ligação $\mathrm{O}-\mathrm{H}$ (proveniente de ácido carboxílico);

$1.401 \mathbf{~ c m}^{-1}$ : apresenta-se uma deformação angular da ligação O-H (proveniente de ácido carboxílico);

$1.338 \mathrm{~cm}^{-1}$ : apresenta-se uma deformação axial da ligação C-O (ácido carboxílico);

$\mathbf{1 . 2 3 6} \mathbf{c m}^{-1}$ : apresenta-se uma deformação angular da ligação N-H (amida III);

$993 \mathrm{~cm}^{-1}$ : apresenta-se uma absorção do grupo fosfato $\left(\mathrm{PO}_{4}{ }^{3-}\right)$;

$869 \mathrm{~cm}^{-1}$ : apresenta-se uma absorção do grupo fosfato $\left(\mathrm{PO}_{4}{ }^{3-}\right)$.

No caso da amostra D52REF, os compostos orgânicos e inorgânicos encontrados foram os mesmos quando comparado com o espectro identificado como D81REF descritos anteriormente.

A Figura 53 apresenta e estabelece uma comparação entre os espectros das amostras de referência (D81REF, D52REF) e na amostra submetida à irradiação gama com uma dose total de 72Gy (D74 1708). Observa-se de modo geral uma completa alteração do espectro obtido para a amostra irradiada quando comparado com os espectros referenciais, no qual se destaca que a maioria das bandas nesse espectro desapareceram, e surgiram novas bandas na

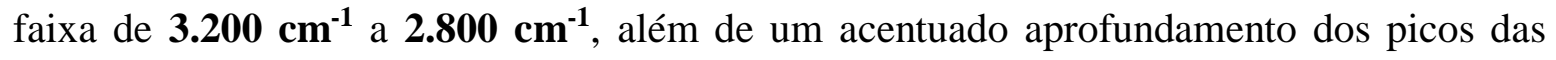
bandas que surgiram $2.923 \mathbf{~ c m}^{-1}$ e $\mathbf{2 . 8 5 2} \mathbf{~ c m}^{-1}$ quando comparados com os das amostras controle. 
Figura 53. Espectroscopia por absorção no infravermelho médio das amostras controle e irradiada de dentina radicular

Dentina radicular

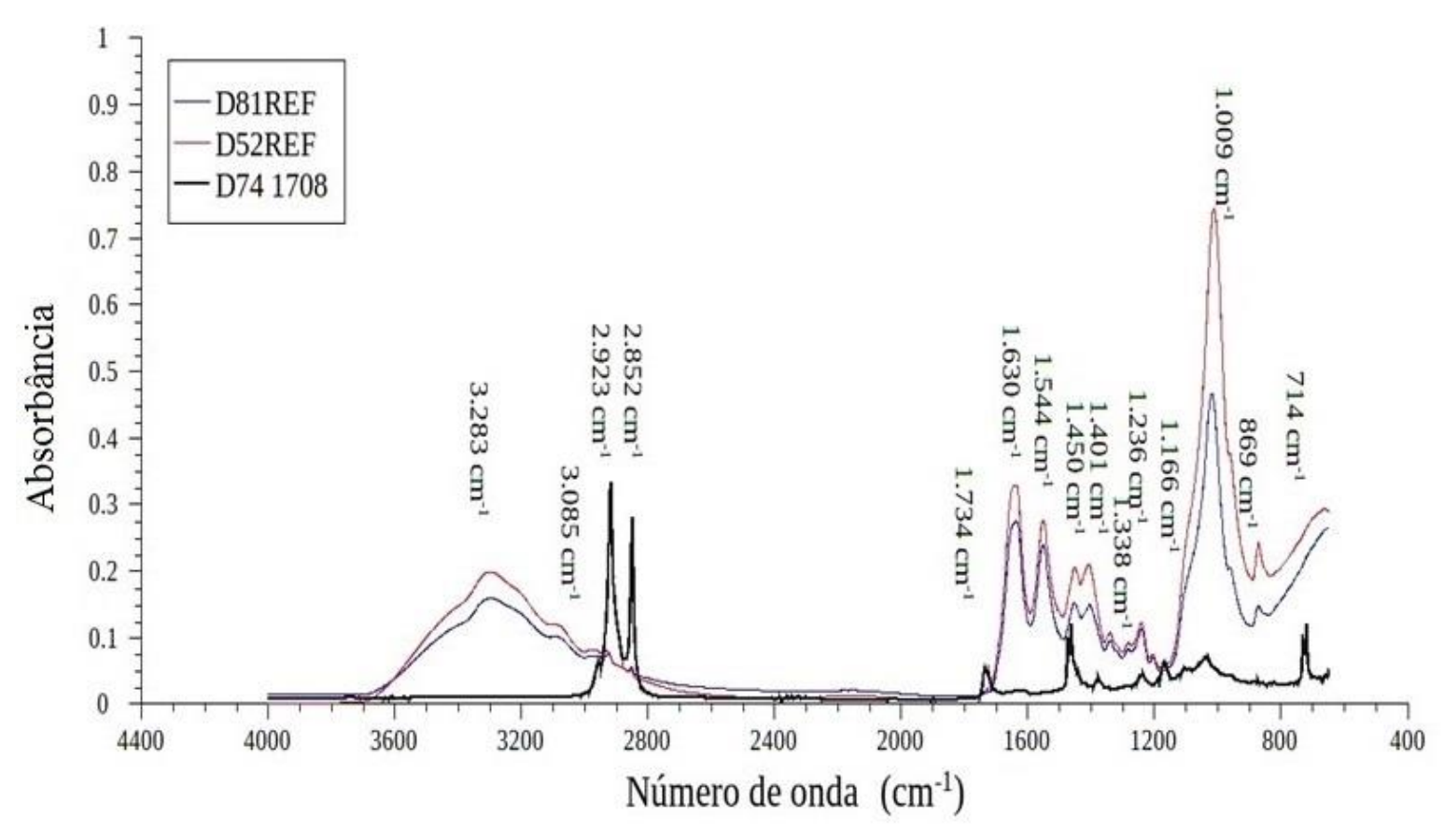

Fonte: Elaborado pelo autor no programa Labplot, Origin para Linux

A Figura 54 apresenta e estabelece uma comparação entre os espectros submetidos à irradiação gama com uma dose total de 72Gy. Observa-se de forma geral uma variação na intensidade dos espectros referente aos picos de absorção das bandas obtidas. 
Figura 54. Espectroscopia por absorção no infravermelho médio das amostras irradiadas de dentina radicular

Dentina Radicular

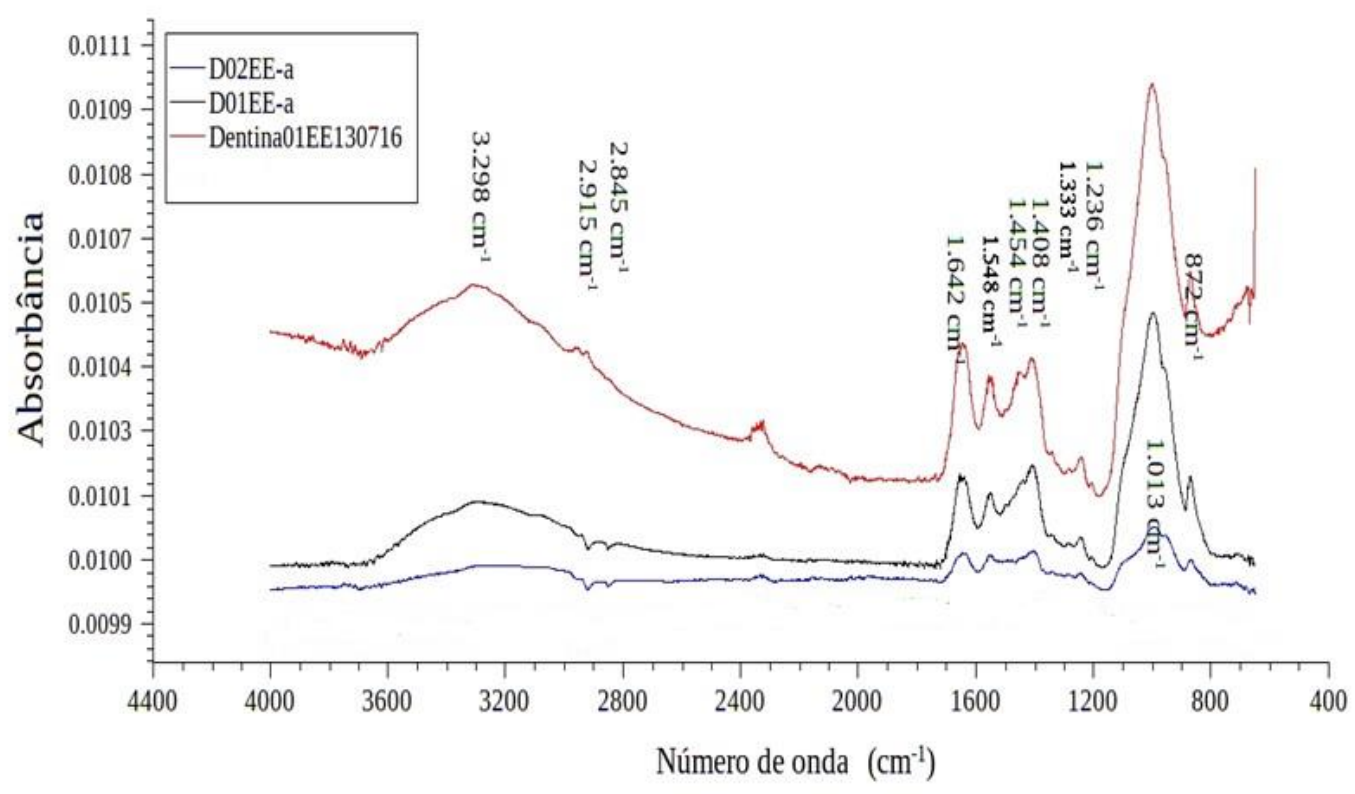

Fonte: Elaborado pelo autor no programa Labplot, Origin para Linux

O espectro da amostra D02EE apresenta uma intensidade muito baixa, quando comparado aos outros espectros; porém, o comportamento das bandas no que diz respeito aos elementos químicos detectados nos picos de absorção é similar nos três espectros. Excetuase duas bandas que surgiram no espectro da amostra Dentina01EE130716, banda $3.073 \mathrm{~cm}^{-1}$ e $1.446 \mathrm{~cm}^{-1}$. A primeira banda corresponde à deformação axial $\mathrm{C}-\mathrm{H}$ (hidrocarboneto) e no segundo caso à deformação axial C-H (hidrocarboneto). Por outro lado, nota-se uma evidente diferença de intensidade dos picos de absorção entre cada uma das amostras, sendo que a amostra D40 apresenta uma diferença substancial das bandas quando comparada com as outras amostras. No caso da amostra D40 observa-se bandas muito fracas e outras quase desaparecidas devido a uma intensidade extremamente fraca, pelo qual não se destaca composto absorvido pela acentuada alteração do espectro mostrado. 
O espectro apresentado na Figura 55 mostra as bandas de absorção correspondente à radiação infravermelha na faixa espectral do infravermelho próximo por partes dos compostos orgânicos e inorgânicos pertencentes à região do corpo mandibular. A primeira banda detectada na região de $\mathbf{8 6 5 \mathbf { c m } ^ { - 1 }}$ corresponde à absorção da radiação por parte do fosfato, componente inorgânico presente nos tecidos duros da cavidade bucal, cujo pico de absorção difere em ambas as amostras.

Figura 55. Espectroscopia por absorção no infravermelho médio das amostras controle de corpo mandibular

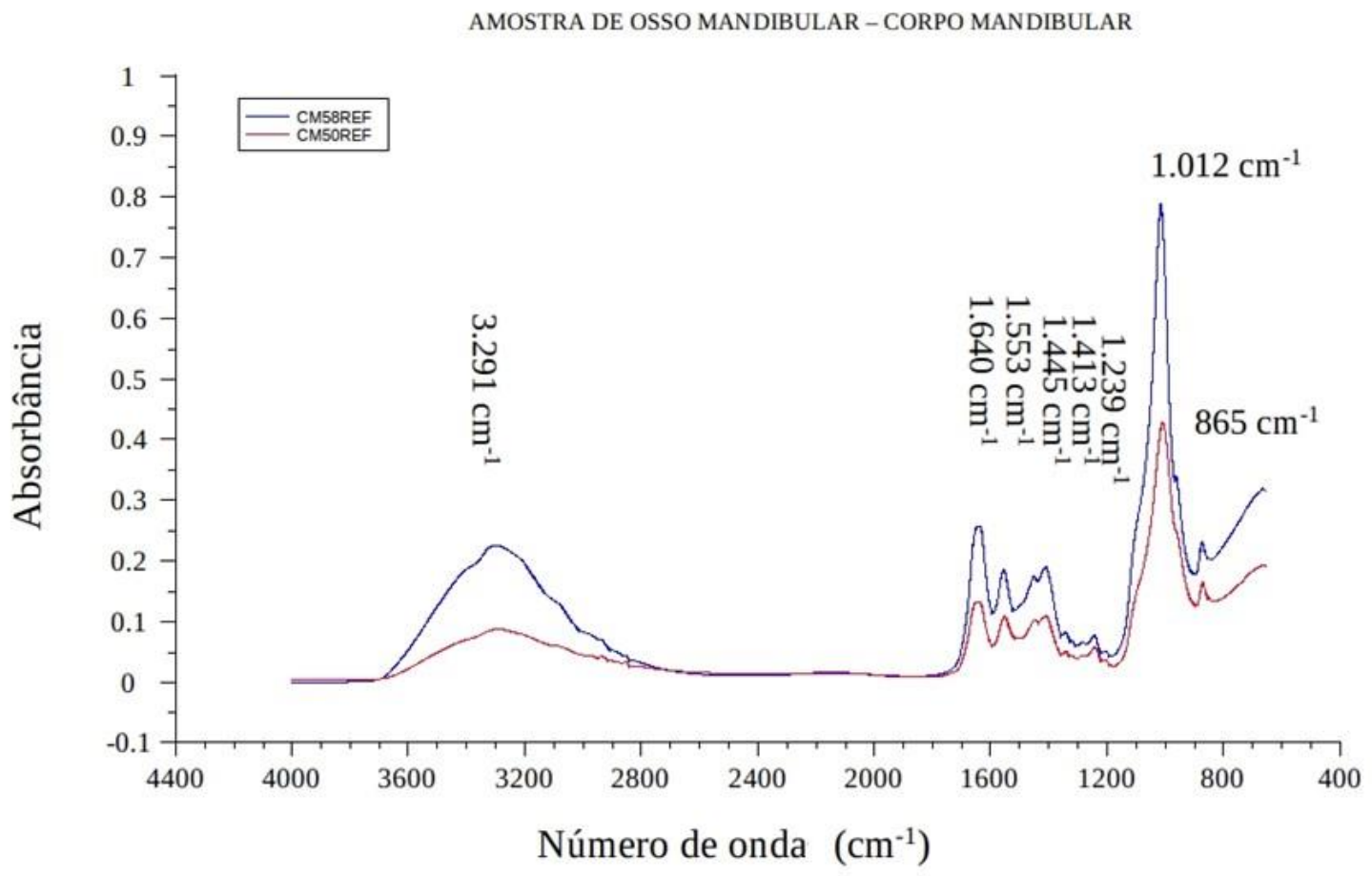

Fonte: Elaborado pelo autor no programa Labplot, Origin para Linux

A Figura 56, apresenta uma comparação estabelecida entre os espectros de absorção das amostras controle (CM58REF, CM50REF) e irradiada (CM02). É visível a diminuição da intensidade das bandas absorvidas pela amostra após a irradiação de 72Gy quando comparada com as amostras controle. Qualitativa e comparativamente, os espectros apresentam um comportamento similar, com a absorção da radiação infravermelha pelos 
compostos das amostras não tratadas, quando comparadas com a amostra que recebeu a irradiação gama.

Figura 56. Espectroscopia por absorção no infravermelho médio das amostras controle e irradiada de corpo mandibular

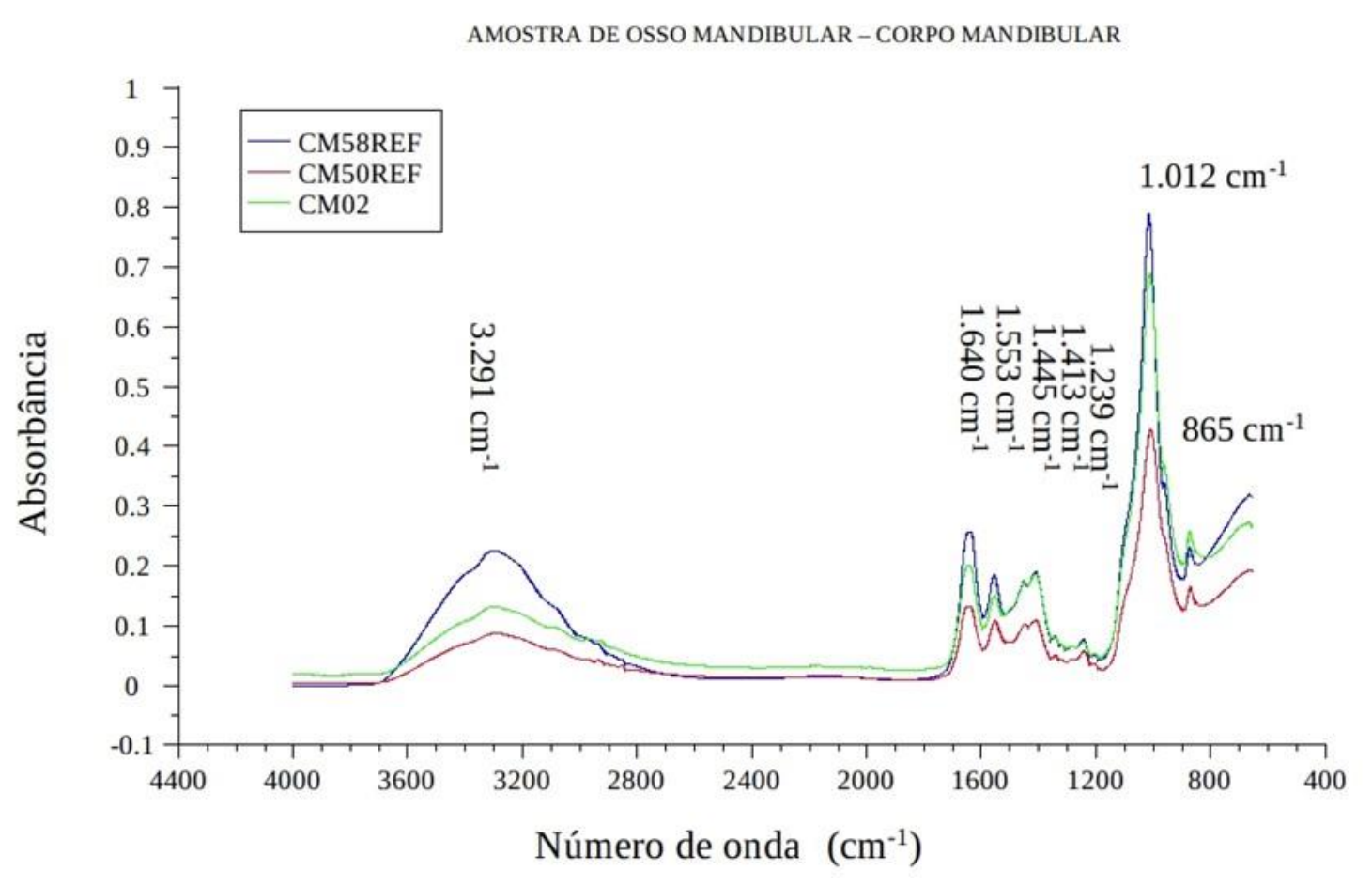

Fonte: Elaborado pelo autor no programa Labplot, Origin para Linux

A

Figura 57 apresenta e estabelece uma comparação entre os espectros das amostras não irradiadas (CM58REF, CM50REF) e da amostra que recebeu uma dose total de 72Gy (CM09). Pode-se evidenciar a completa alteração do espectro da amostra irradiada quando comparado com os espectros referenciais, visualizando-se o desaparecimento das bandas $3.291 \mathrm{~cm}^{-1}, 1.643 \mathrm{~cm}^{-1}, 1.553 \mathrm{~cm}^{-1}, 1.413 \mathrm{~cm}^{-1}, 1.012 \mathrm{~cm}^{-1}$ e $865 \mathrm{~cm}^{-1}$. Por outro lado, surgem outras bandas de muito baixa intensidade as quais manifestam uma evidente alteração estrutural e composicional do tecido duro submetido à irradiação gama. 
Figura 57. Espectroscopia por absorção no infravermelho médio das amostras controle e irradiada de corpo mandibular

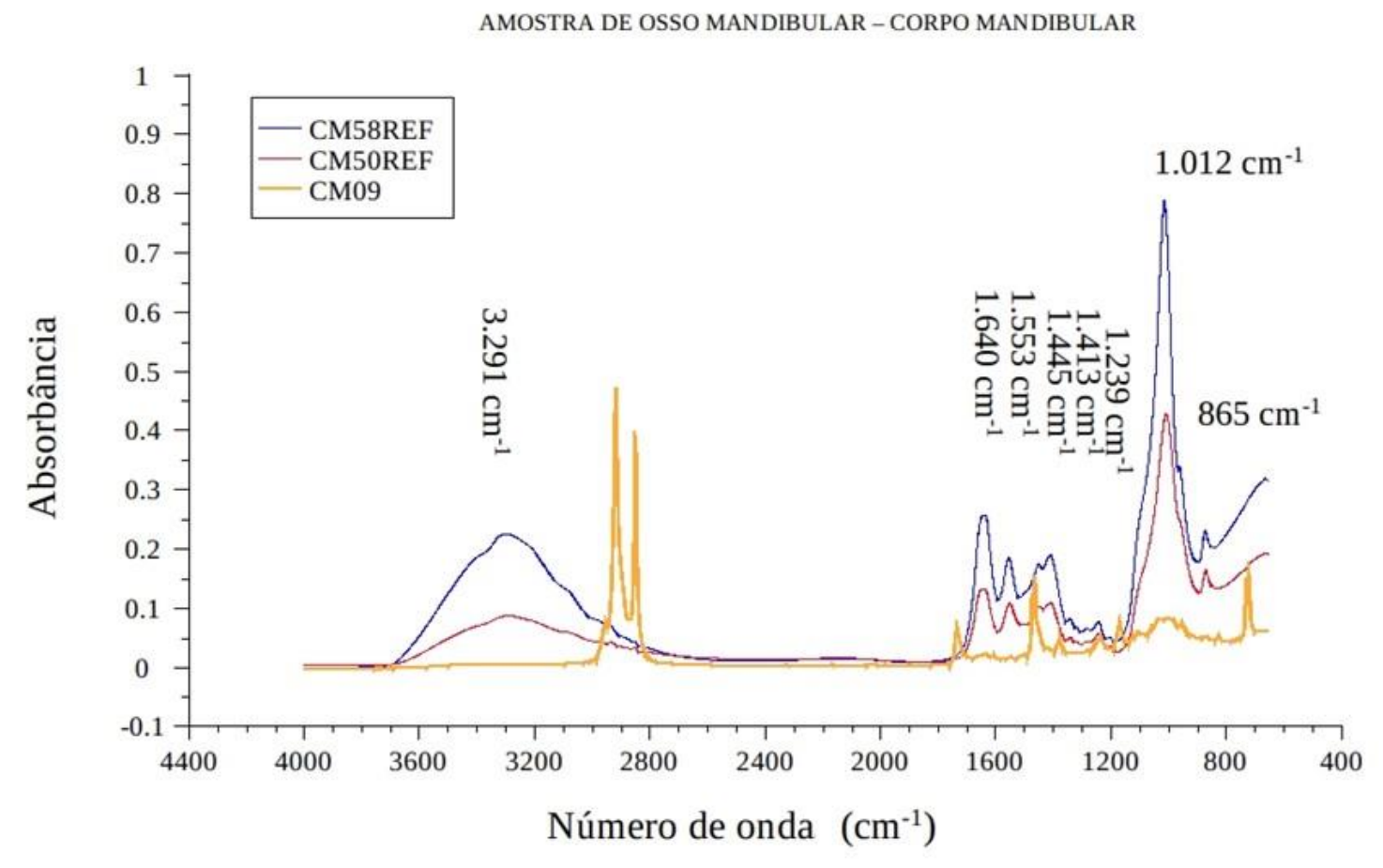

Fonte: Elaborado pelo autor no programa Labplot, Origin para Linux

O gráfico da Figura 58 apresenta e estabelece uma comparação entre os espectros das amostras controle (CM58REF, CM50REF) e da amostra submetida à irradiação gama com uma dose total de 72Gy (CM15). Evidencia-se uma diminuição na intensidade das bandas absorvidas quanto aos picos de absorção da radiação infravermelha pelos compostos orgânicos e inorgânicos detectados na análise espectral. Observa-se uma diminuição da

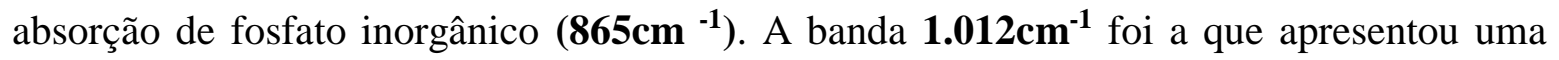
maior diminuição de intensidade quando comparada com os espectros das amostras controle.

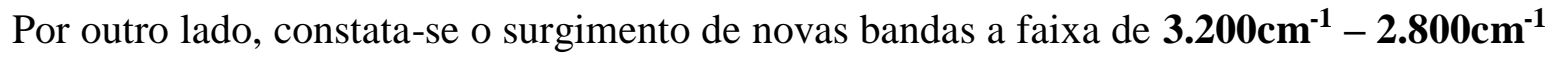

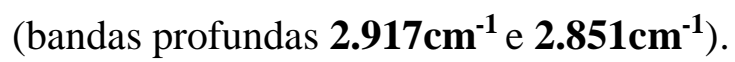


Figura 58. Espectroscopia por absorção no infravermelho médio das amostras controle e irradiada de corpo mandibular

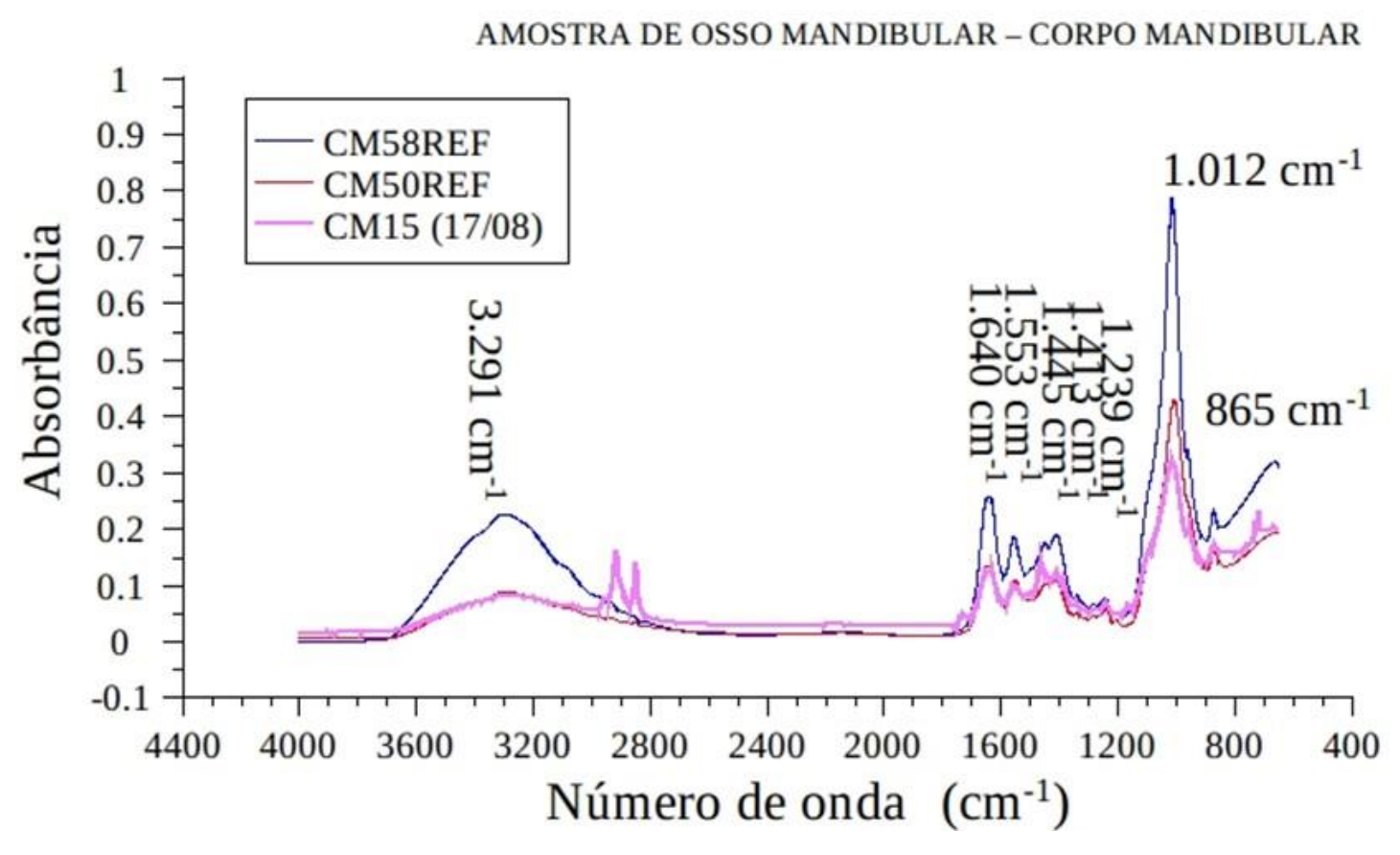

Fonte: Elaborado pelo autor no programa Labplot, Origin para Linux

A Figura 59 apresenta e estabelece uma comparação espectral entre os espectros das amostras de referência (CM58REF, CM50REF) e o espectro da amostra submetida à irradiação gama com uma dose total de 72Gy (CM30). Observa-se um comportamento similar de absorção no que diz respeito às bandas obtidas por todos os espectros, porém quando o espectro da amostra irradiada é comparado com o espectro da amostra CM58REF evidencia-se uma diminuição na intensidade dos picos das bandas obtidas em todas as regiões da faixa espectral, sendo a banda $\mathbf{1 . 0 1 2 \mathbf { c m } ^ { - 1 }}$ a de maior diminuição em intensidade que apresenta a amostra CM30. 
Figura 59. Espectroscopia por absorção no infravermelho médio das amostras controle e irradiada de corpo mandibular

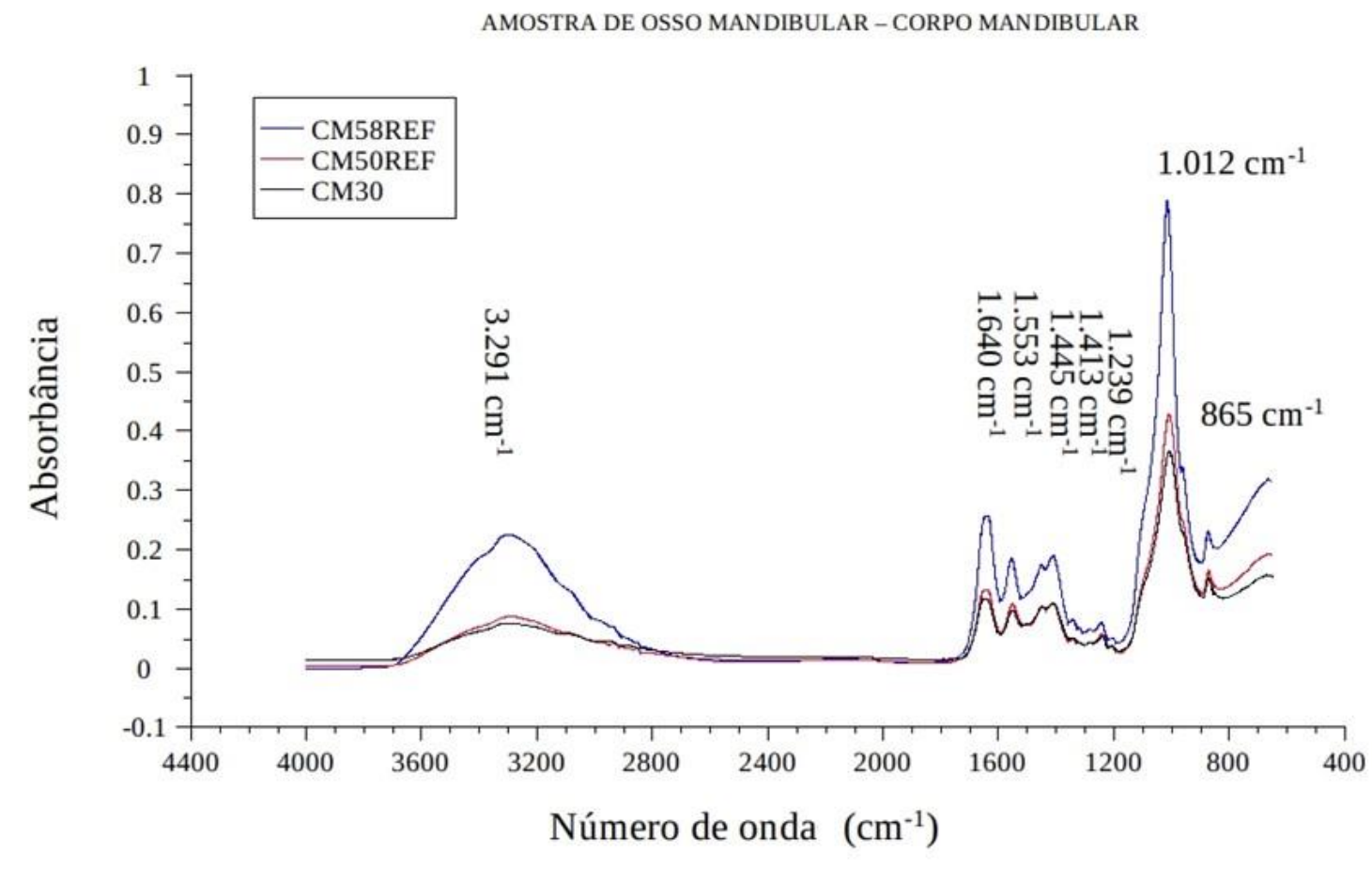

Fonte: Elaborado pelo autor no programa Labplot, Origin para Linux

A Figura 60 apresenta e estabelece uma comparação espectral entre as amostras de referência (CM58REF, CM50REF) e a amostra submetida à irradiação gama (CM31). As bandas absorvidas em todos os casos apresentam comportamento similar no que diz respeito aos compostos orgânicos e inorgânicos encontrados. Observa-se uma diminuição da

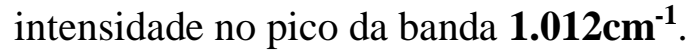


Figura 60. Espectroscopia por absorção no infravermelho médio das amostras controle e irradiada de corpo mandibular

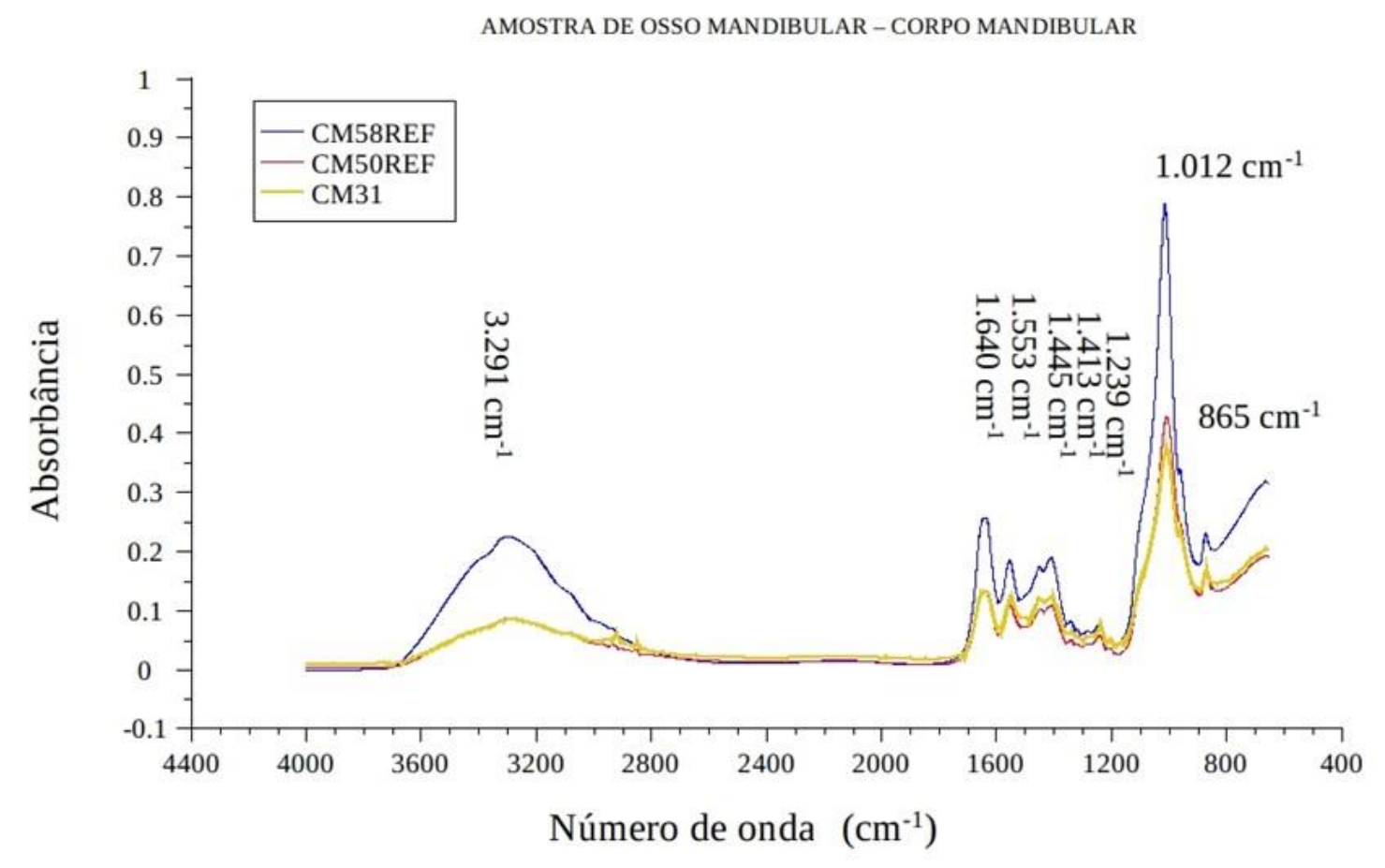

Fonte: Elaborado pelo autor no programa Labplot, Origin para Linux

A Figura 61 apresenta e estabelece uma comparação espectral entre as bandas absorvidas nas amostras controle (CM58REF, CM50REF) e na amostra submetida à irradiação gama (CM33). Observa- se uma diminuição na intensidade do pico da banda $\mathbf{1 . 0 1 2} \mathrm{cm}^{-1}$ da amostra irradiada quando comparada com as amostras controle, evidenciandose uma maior diminuição quando comparada especificamente com a amostra de referência CM58REF. Apresenta-se o restante das bandas em todos os espectros representados no gráfico. 
Figura 61. Espectroscopia por absorção no infravermelho médio das amostras controle e irradiada de corpo mandibular

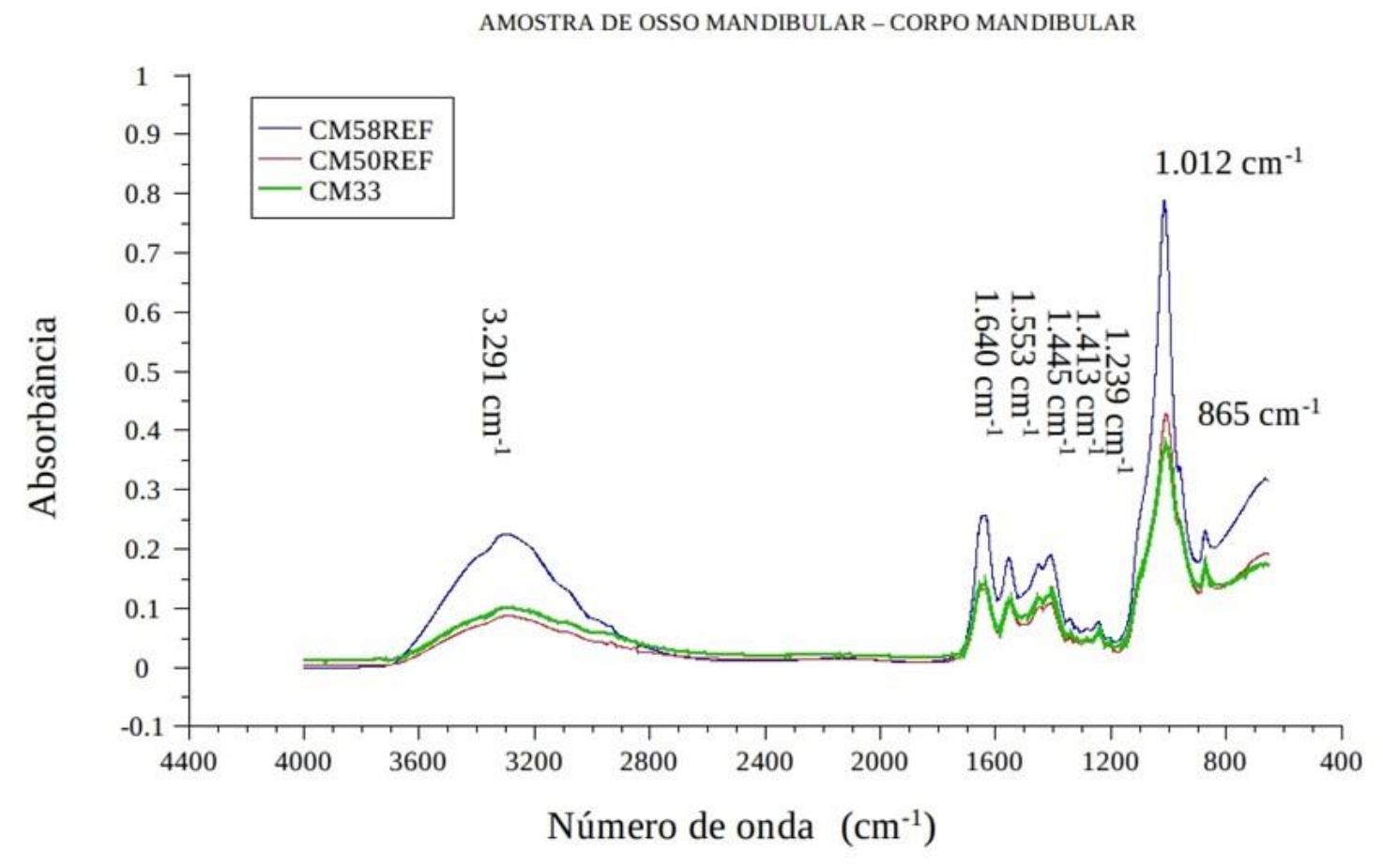

Fonte: Elaborado pelo autor no programa Labplot, Origin para Linux

A Figura 62 apresenta e estabelece uma comparação espectral entre os espectros do grupo controle (CM58REF, CM50REF) e do grupo irradiado (CM34). Neste caso avaliase o espectro da amostra CM34, submetida à irradiação gama com uma dose total de 72Gy, no qual se observa uma clara diminuição da intensidade dos picos das bandas obtidas, correspondentes aos compostos orgânicos e inorgânicos encontrados, absorvendo a radiação infravermelha. Nota-se uma evidente diminuição dos picos das bandas $\mathbf{3 . 2 9 1 \mathbf { c m } ^ { - 1 }}$ e $1.012 \mathrm{~cm}^{-1}$ do espectro obtido da amostra irradiada quando comparado com o espectro da amostra não tratada CM58REF. Por outro lado, descreve-se o aparecimento de picos de

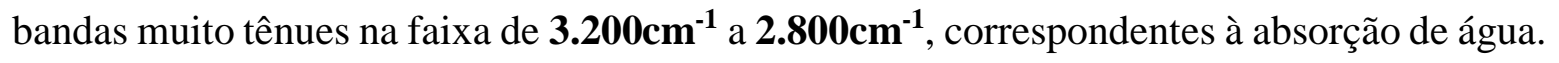


Figura 62. Espectroscopia por absorção no infravermelho médio das amostras controle e irradiada de corpo mandibular

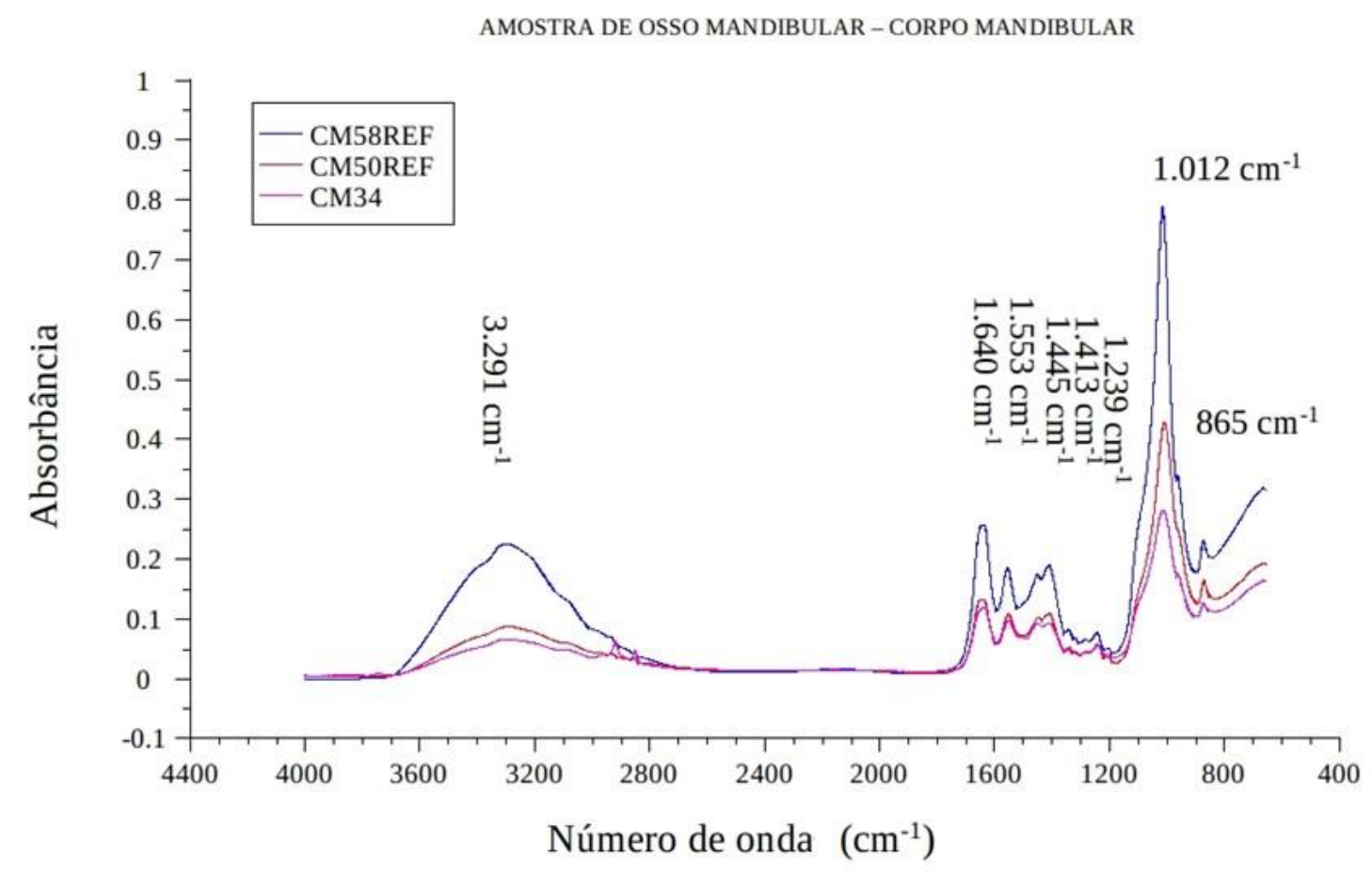

Fonte: Elaborado pelo autor no programa Labplot, Origin para Linux

A Figura 63 apresenta e estabelece uma comparação entre os espectros das amostras controle (CM58REF, CM50REF) e do grupo irradiado (CM39). Neste caso, observam-se as mesmas bandas em todos os espectros analisados, evidenciando-se uma clara diminuição

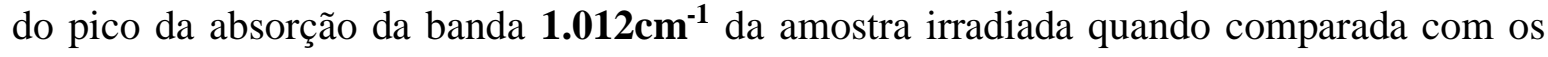
picos das bandas nas amostras controle. Por outro lado, o aparecimento de picos de bandas profundas e de muito baixa intensidade na região de $\mathbf{3 . 2 0 0 \mathbf { c m } ^ { - 1 }}$ e $\mathbf{2 . 8 0 0 \mathbf { c m } ^ { - 1 }}$ foram observados. 
Figura 63. Espectroscopia por absorção no infravermelho médio das amostras controle e irradiada de corpo mandibular

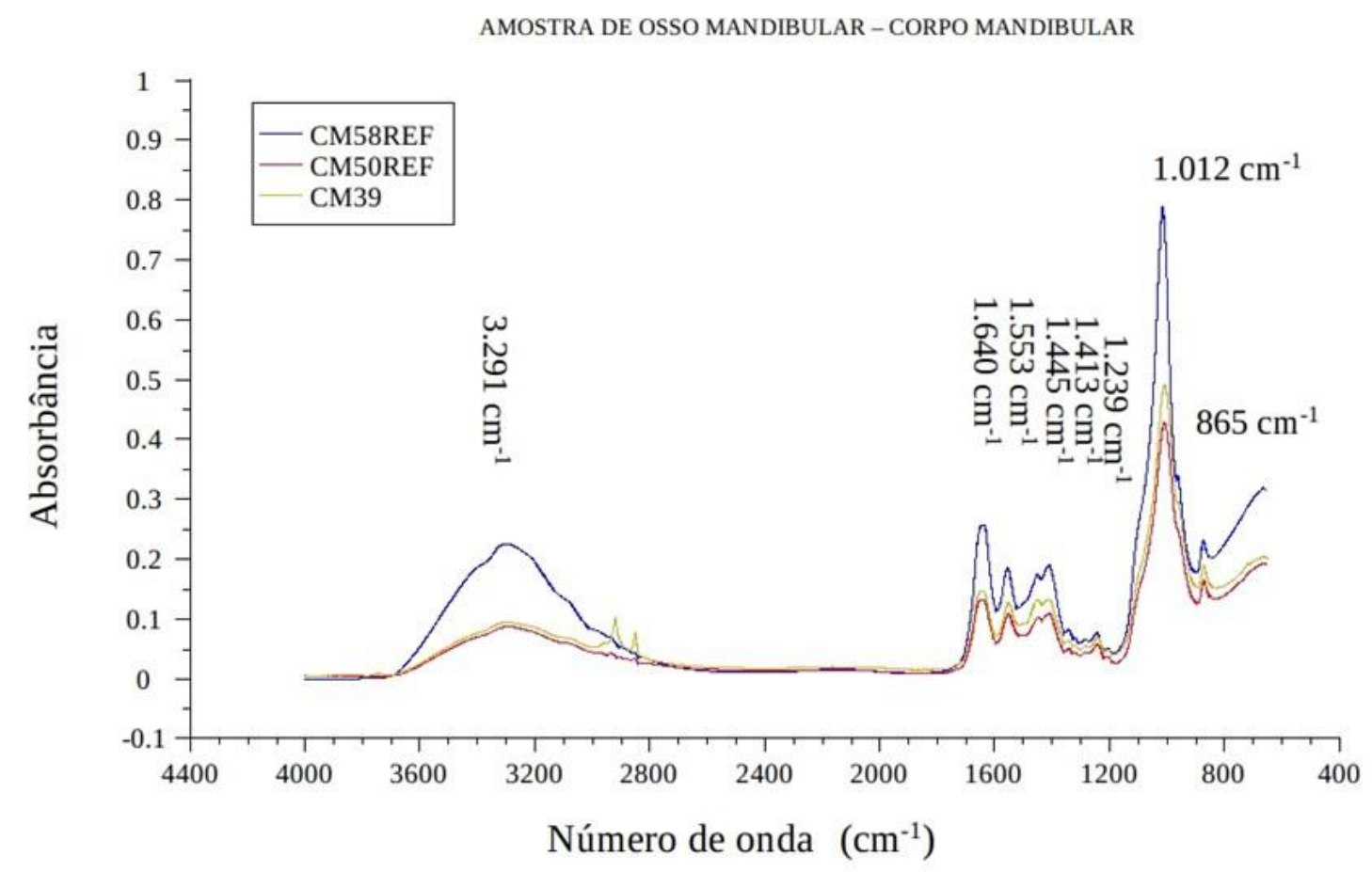

Fonte: Elaborado pelo autor no programa Labplot, Origin para Linux

A Figura 64 apresenta os espectros das amostras de referência (CM58REF, CM50REF) comparados com o espectro da amostra submetida à irradiação gama com uma dose total de 72Gy (CM49). Observa-se o desaparecimento de algumas bandas no caso do espectro da amostra CM49, especificamente a banda $3.291 \mathbf{c m}^{-1}$, a qual representa à deformação angular do radical $\mathrm{OH}^{-}$. Por outro lado, observa-se uma diminuição geral da

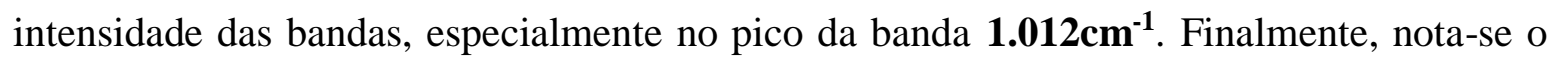

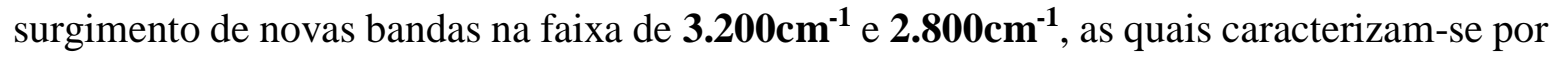
serem profundas, de baixa intensidade, além da banda $1.445 \mathrm{~cm}^{-1}$, a qual caracteriza-se por ser menos intensa quando comparada com as outras bandas do grupo controle. 
Figura 64. Espectroscopia por absorção no infravermelho médio das amostras controle e irradiada de corpo mandibular

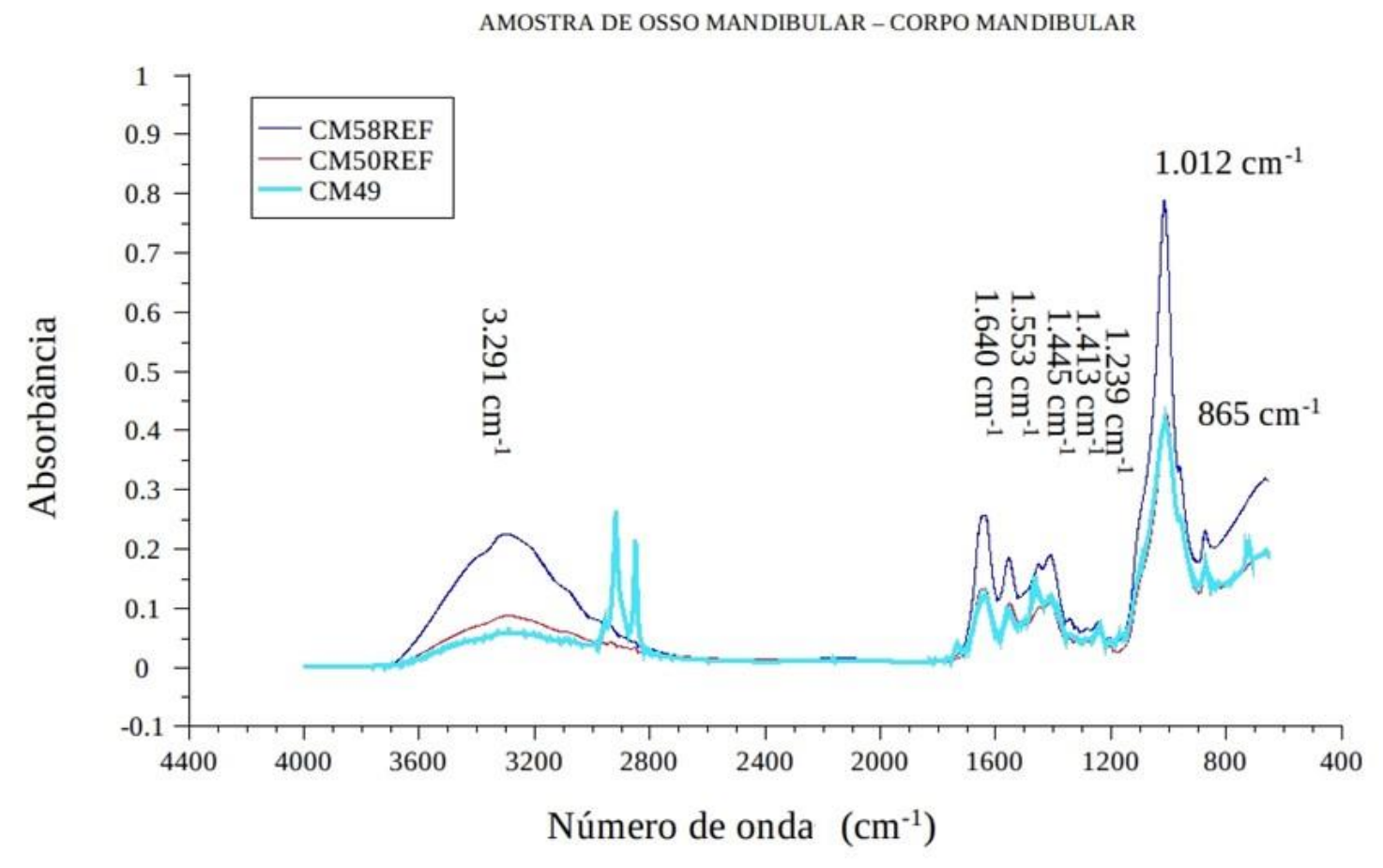

Fonte: Elaborado pelo autor no programa Labplot, Origin para Linux

Na Figura 65 apresentam-se os espectros de absorção das amostras do grupo controle (CM58REF, CM50REF) e da amostra submetida à irradiação gama com uma dose total de 72Gy (CM51). Observa-se uma diminuição geral na intensidade dos picos das bandas obtidas do grupo irradiado quando comparado com os do grupo controle, especificamente o pico da

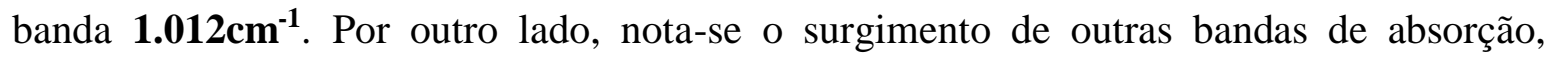

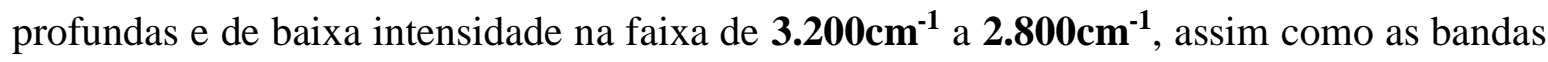
$1.737 \mathrm{~cm}^{-1}, 1.168 \mathrm{~cm}^{-1}, 1.113 \mathrm{~cm}^{-1}$ e $719 \mathrm{~cm}^{-1}$. Finalmente, constata-se o desaparecimento da banda $3.291 \mathrm{~cm}^{-1}$. 
Figura 65. Espectroscopia por absorção no infravermelho médio das amostras controle e irradiada de corpo mandibular

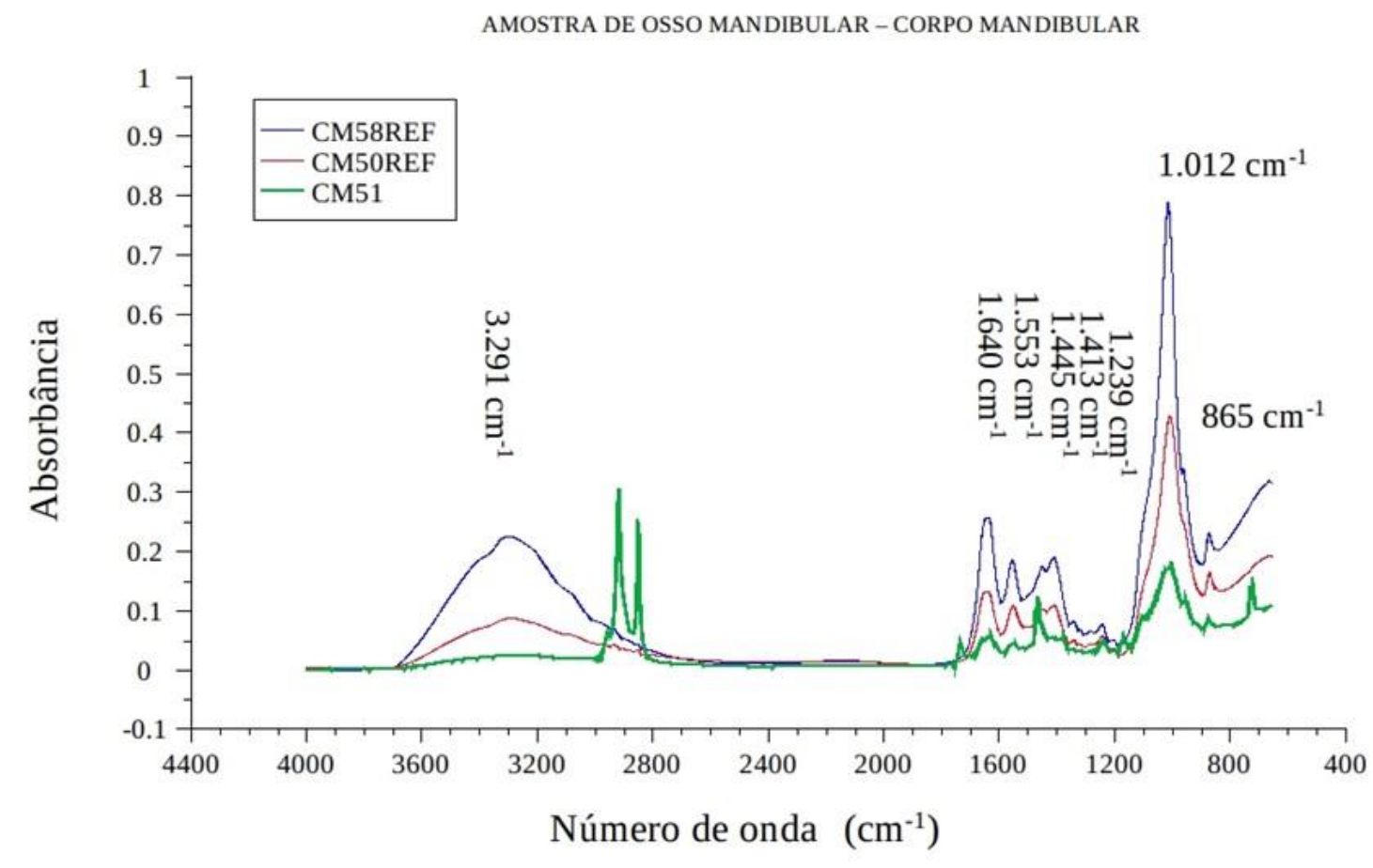

Fonte: Elaborado pelo autor no programa Labplot, Origin para Linux

Na Figura 66 observa-se um comportamento espectral similar em todos os espectros apresentados, tanto do grupo controle (CM58REF, CM50REF) quanto da amostra irradiada (CM54). Nota-se uma diminuição geral na intensidade dos picos das bandas obtidas no espectro da amostra irradiada (CM54) principalmente quando comparada com a amostra controle (CM58REF). Constata-se uma diminuição acentuada do pico de absorção da banda $\mathbf{1 . 0 1 2} \mathbf{~ c m}^{-1}$ quando comparada com as outras bandas de absorção. 
Figura 66. Espectroscopia por absorção no infravermelho médio das amostras controle e irradiada de corpo mandibular

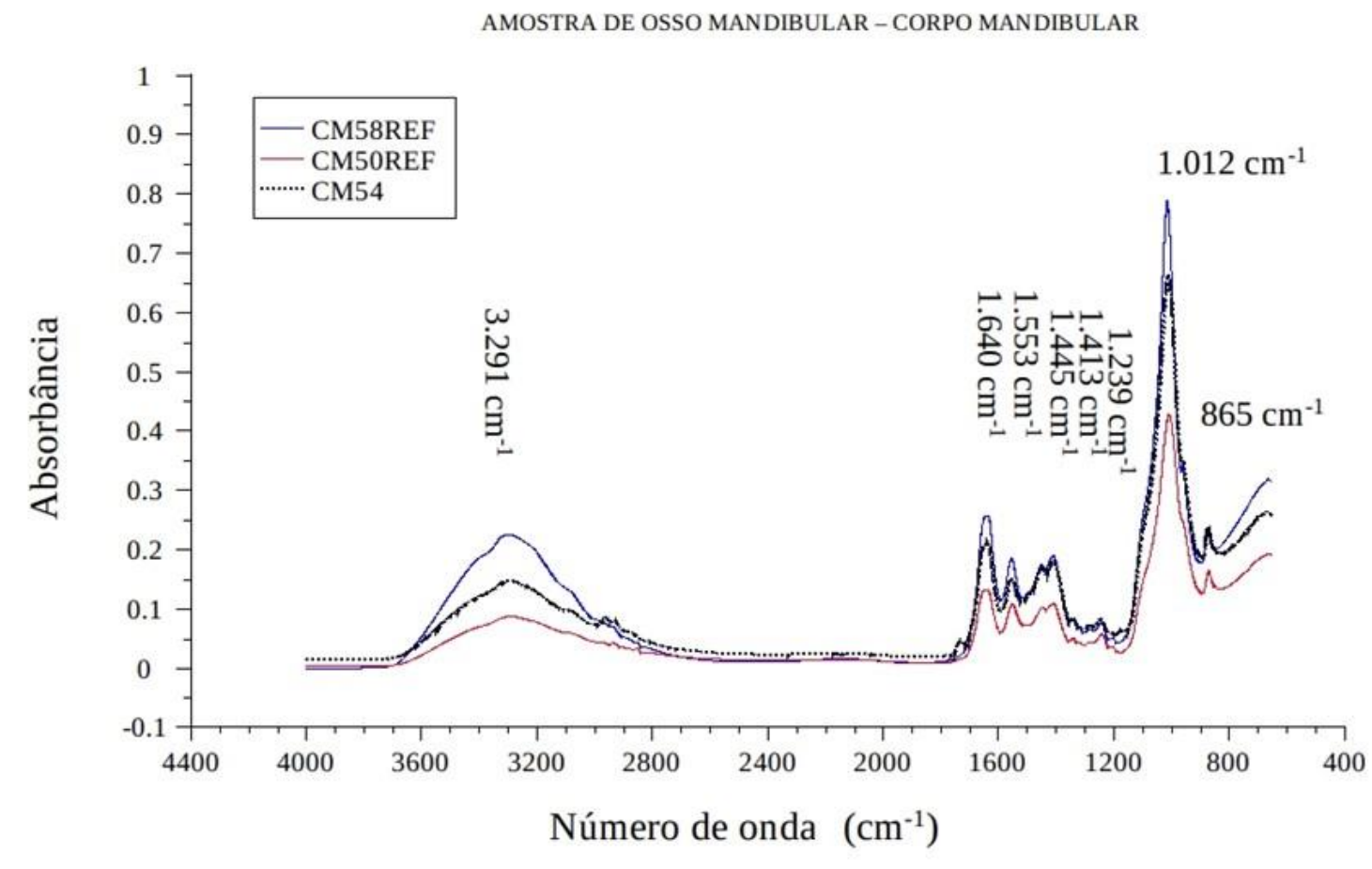

Fonte: Elaborado pelo autor no programa Labplot, Origin para Linux

Na Figura 67 apresentam-se os espectros das amostras do grupo de referência (CM58REF, CM50REF) e a amostra submetida à irradiação gama (CM58). Observa-se um comportamento similar das bandas no que diz respeito à quantidade e às bandas absorvidas propriamente ditas. Nota-se uma diminuição geral da intensidade do espectro correspondente à amostra irradiada, especificamente os picos de absorção das bandas $\mathbf{3 . 2 9 1 \mathbf { c m } ^ { - 1 }}$ e $1.012 \mathrm{~cm}^{-1}$ principalmente. 
Figura 67. Espectroscopia por absorção no infravermelho médio das amostras controle e irradiada de corpo mandibular

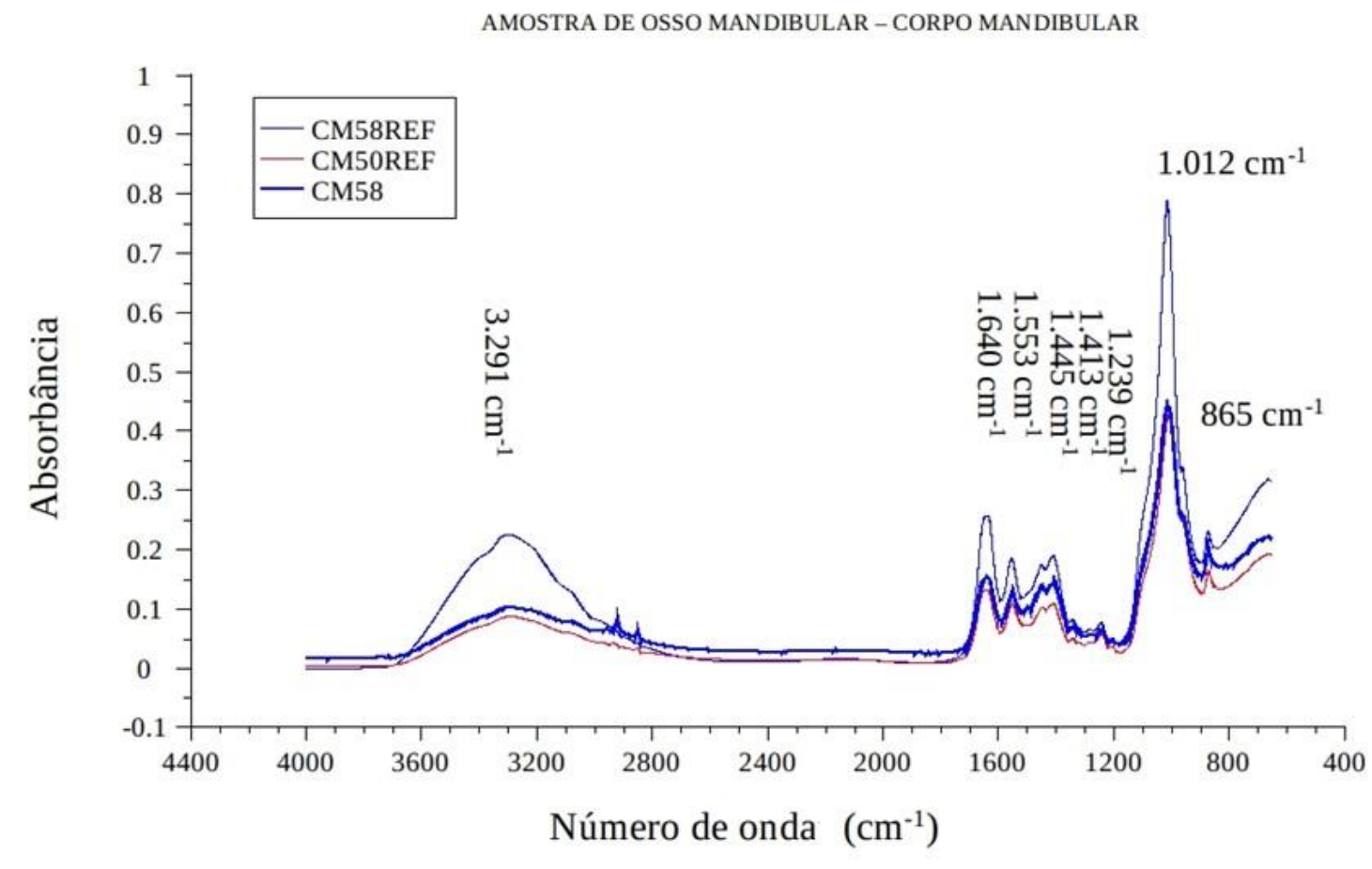

Fonte: Elaborado pelo autor no programa Labplot, Origin para Linux

A Figura 68 a seguir apresenta os espectros por absorbância das amostras controle (TRM55REF, TRM56REF), as quais não foram submetidas à irradiação gama. Observamse diferentes picos de bandas geradas, o que representa a absorção da radiação infravermelha pelos diferentes compostos orgânicos e inorgânicos, os quais fazem parte do arcabouço composicional deste tecido duro. 
Figura 68. Espectroscopia por absorção no infravermelho médio das amostras controle da região do trígono retromolar

\section{Região do trígono retromolar}

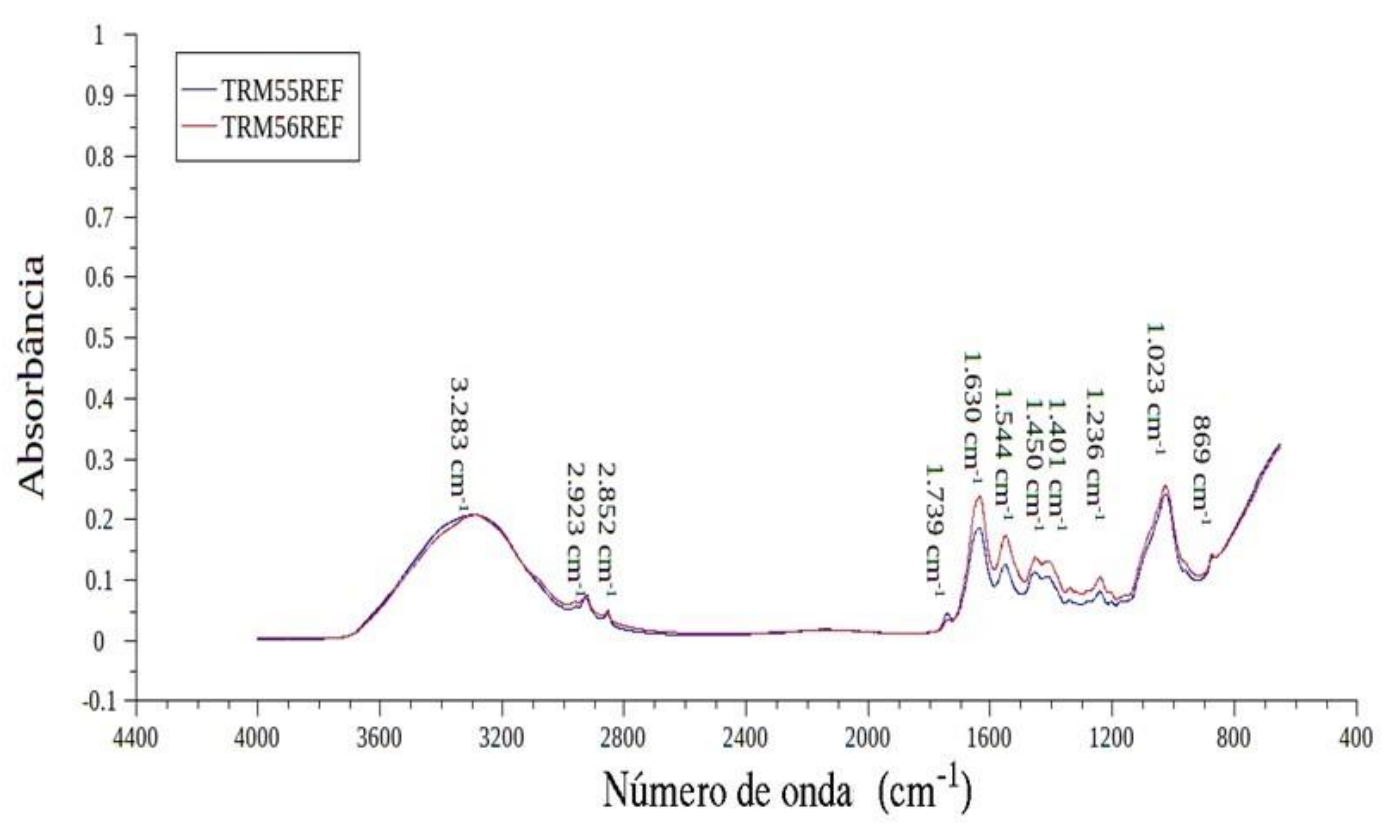

Fonte: Elaborado pelo autor no programa Labplot, Origin para Linux

A seguir serão descritos os comportamentos das diferentes bandas apresentadas nos espectros, observando-se semelhanças com os espectros das amostras não irradiadas da região do corpo mandibular, no entanto, há a presença das seguintes bandas:

3.283 cm$^{-1}$ : apresenta-se uma deformação axial da ligação de $\mathrm{O}-\mathrm{H}$, correspondente aos cristais de hidroxiapatita presentes na matriz inorgânica do tecido;

$2.923 \mathrm{~cm}^{-1}$ : apresenta-se uma deformação axial assimétrica da ligação $\mathrm{C}-\mathrm{H}$, correspondente ao grupo metileno do hidrocarboneto (matriz orgânica);

$2.852 \mathbf{~ c m}^{-1}$ : apresenta-se uma deformação axial assimétrica da ligação $\mathrm{C}-\mathrm{H}$, correspondente também ao grupo metileno de hidrocarboneto;

$1.739 \mathrm{~cm}^{-1}$ : apresenta-se uma deformação axial da ligação do grupo peróxido (O-C-C); 
1.630 cm$^{-1}$ : apresenta-se uma deformação angular da ligação N-H, correspondente ao grupo amida I (matriz orgânica);

$\mathbf{1 . 5 4 4} \mathbf{~ c m}^{-1}$ : interpreta-se como uma deformação angular da ligação N-H, correspondente ao grupo amida II (matriz orgânica);

$1.450 \mathrm{~cm}^{-1}$ : correspondente à deformação angular da ligação $\mathrm{O}-\mathrm{H}$, proveniente de ácido carboxílico;

$1.401 \mathrm{~cm}^{-1}$ : apresenta-se uma deformação angular da ligação $\mathrm{O}-\mathrm{H}$, proveniente de ácido carboxílico;

$1.236 \mathbf{~ c m}^{-1}$ : corresponde à deformação angular da ligação $\mathrm{N}-\mathrm{H}$, correspondente ao grupo amida III (matriz orgânica);

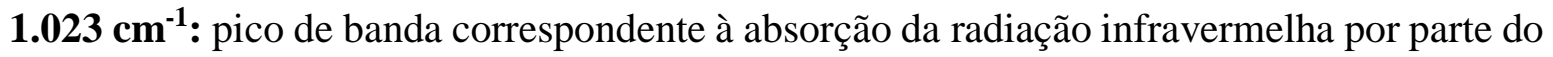
grupo fosfato (matriz inorgânica);

$869 \mathrm{~cm}^{-1}$ : correspondente à absorção da radiação por parte do grupo fosfato (matriz inorgânica).

Para o caso do gráfico espectral da amostra controle TRM56REF apresentam- se os mesmos picos de absorção por parte dos compostos orgânicos e inorgânicos anteriormente descritos.

Na Figura 69 apresentam-se os espectros das amostras submetidas à irradiação gama (TRM02, TRM07, TRM51) através de análise por reflexão total atenuada (ATR - FTIR). Observa-se um comportamento similar entre as bandas obtidas em cada espectro, sendo que a intensidade dos picos de absorção desta varia levemente de uma amostra para outra. Os picos de absorção das bandas na amostra TRM07 apresentam uma maior intensidade quando comparada com as outras amostras. A amostra TRM51 apresenta picos de absorção das bandas semelhantes aos da amostra TRM02, porém, com uma notável diminuição do pico de absorção da banda $\mathbf{1 . 0 0 4} \mathbf{~ c m}^{-1}$ quando comparada com o pico de absorção da mesma banda na amostra TRM07. 
Figura 69. Espectroscopia por absorção no infravermelho médio das amostras irradiadas da região do trígono retromolar

Trígono retromolar

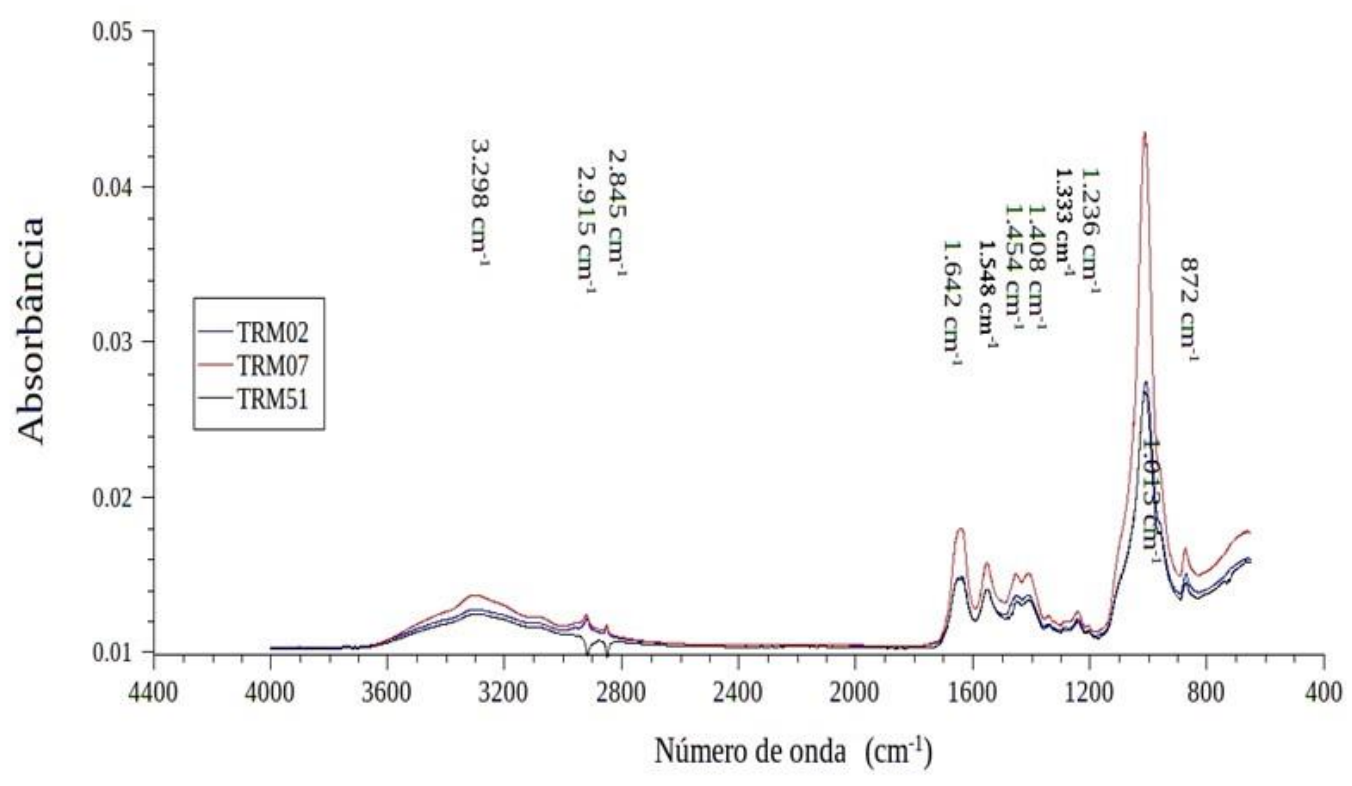

Fonte: Elaborado pelo autor no programa Labplot, Origin. Para Linux

A seguir, apresentam-se os compostos bioquímicos representados pelos picos de absorção na região espectral para a amostra TRM02:

$3.425 \mathbf{~ c m}^{-1}$ : apresenta-se uma deformação axial da ligação O-H (correspondente aos cristais de hidroxiapatita, os quais fazem parte da matriz inorgânica do tecido duro analisado) ou NH livre (matriz orgânica);

$3.313 \mathrm{~cm}^{-1}$ : apresenta-se uma deformação axial da ligação $\mathrm{O}-\mathrm{H}$ (correspondente à estrutura dos cristais de hidroxiapatita, os quais fazem parte da matriz inorgânica do tecido duro analisado) ou N-H (matriz orgânica);

$\mathbf{3 . 0 7 3} \mathbf{~ c m}^{-1}$ : apresenta-se uma deformação axial C-H (hidrocarboneto);

2.953 cm$^{-1}$ : apresenta-se uma deformação da ligação C-H alifático;

2.927 cm$^{-1}$ : apresenta-se uma deformação axial assimétrica da ligação C -H (grupo metileno de hidrocarboneto); 
$\mathbf{2 . 8 4 8}$ cm$^{-1}$ : apresenta-se uma deformação axial simétrica da ligação C-H (grupo metileno de hidrocarboneto);

1.641 cm$^{-1}$ : apresenta-se uma deformação angular da ligação N-H (amida I), correspondente à matriz orgânica do tecido duro analisado;

$1.548 \mathrm{~cm}^{-1}$ : apresenta-se uma deformação angular da ligação N-H (amida II), correspondente à matriz orgânica do tecido duro analisado;

$1.446 \mathrm{~cm}^{-1}$ : apresenta-se uma deformação angular da ligação O-H (proveniente de ácido carboxílico);

$1.405 \mathbf{~ c m}^{-1}$ : apresenta-se uma deformação angular da ligação O-H (proveniente de ácido carboxílico);

$\mathbf{1 . 3 3 4} \mathrm{cm}^{-1}$ : apresenta-se uma deformação axial da ligação C-O (ácido carboxílico);

$\mathbf{1 . 2 3 6} \mathbf{~ c m}^{-1}$ : apresenta-se uma deformação angular da ligação N-H (amida III);

$1.008 \mathrm{~cm}^{-1}$ : apresenta-se a absorção do grupo $\mathrm{PO}_{4}{ }^{3-}$ (fosfato), correspondente à matriz inorgânica do tecido duro analisado;

$865 \mathrm{~cm}^{-1}$ : apresenta-se a absorção do grupo $\mathrm{PO}_{4}{ }^{3-}$ (fosfato), correspondente à matriz inorgânica do tecido duro analisado.

A amostra TRM07 apresentou os mesmos compostos anteriormente descritos na amostra TRM02, porém, com picos de absorção de maior intensidade. No caso do espectro da amostra TRM51 não foram encontrados elementos químicos significativos pelo fato desta apresentar picos de absorção de menor intensidade.

Na Figura 70 apresentam-se os espectros das amostras submetidas à irradiação gama (TRM10, TRME01, TRM22) através de análise por reflexão total atenuada (ATR - FTIR). Observa-se um comportamento similar entre as bandas obtidas em cada espectro, sendo que a intensidade dos picos de absorção desta varia levemente de uma amostra para outra, excetuando-se o espectro da amostra irradiada TRME01, já que esta apresenta picos de absorção quase nulos, de muito baixa intensidade. Os picos de absorção das bandas na 
amostra TRM07 apresentam uma maior intensidade quando comparados com os picos das outras amostras. A amostra TRM10 apresenta picos de absorção das bandas semelhantes aos da amostra TRM22. Finalmente, notam-se os mesmos compostos orgânicos e inorgânicos detectados em todos os espectros e descritos anteriormente nos espectros das amostras TRMO2 e TRM07.

Figura 70. Espectroscopia por absorção no infravermelho médio das amostras irradiadas da região do trígono retromolar

Trígono retromolar

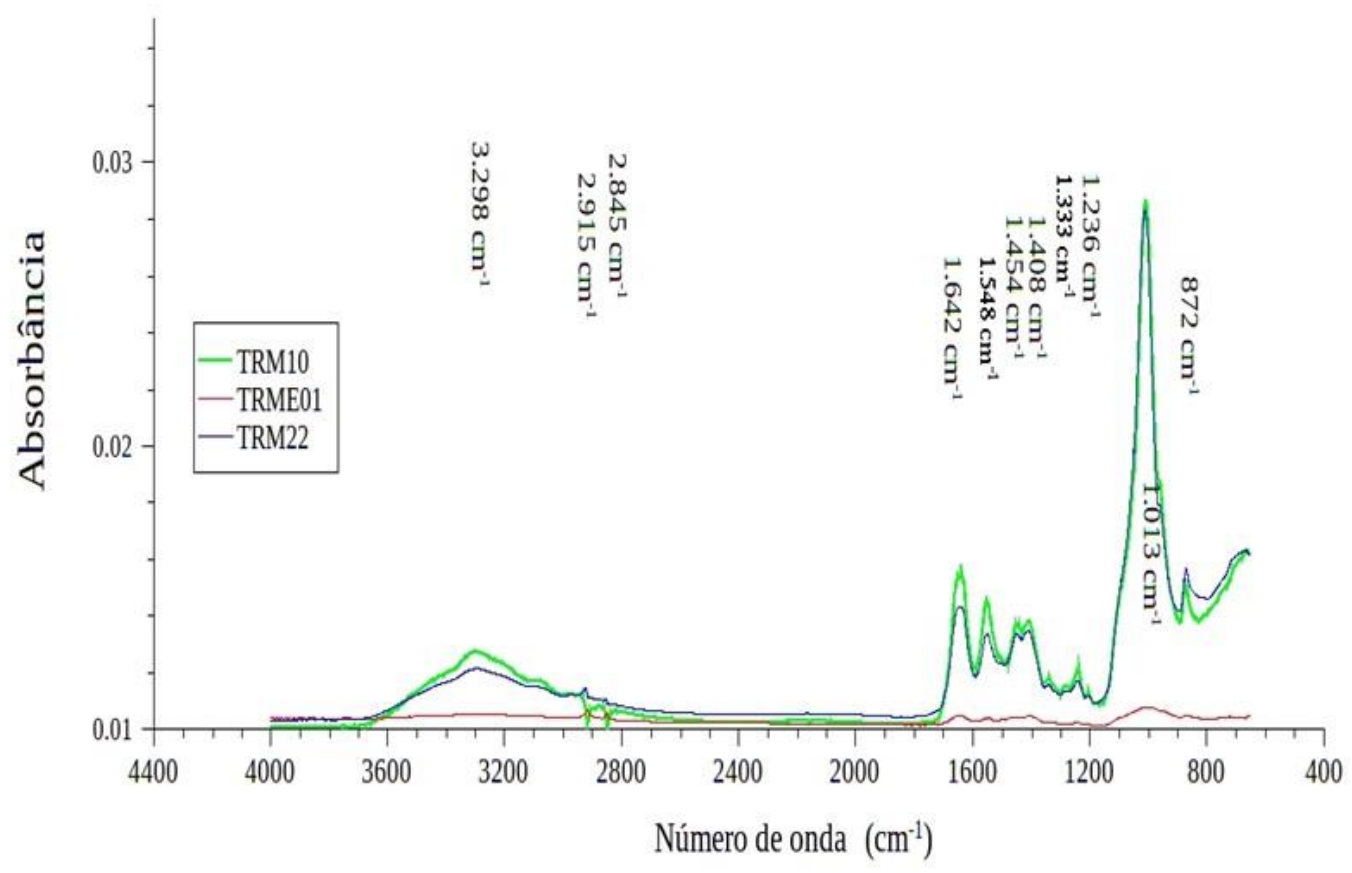

Fonte: Elaborado pelo autor no programa Labplot; Origin para Linux

Na Figura 71 apresenta-se os espectros das amostras submetidas à irradiação gama (TRM23, TRM24, TRM34) através de análise por reflexão total atenuada (ATR - FTIR). Observa-se um comportamento similar entre as bandas obtidas em cada espectro, sendo que a intensidade dos picos de absorção desta varia levemente de uma amostra para outra. Por 
outro lado, notam-se os mesmos compostos orgânicos e inorgânicos detectados em todos os espectros e descritos anteriormente tais como os espectros da amostra TRM02 e TRM07.

Figura 71. Espectroscopia por absorção no infravermelho médio das amostras irradiadas da região do trígono retromolar

Trígono retromolar

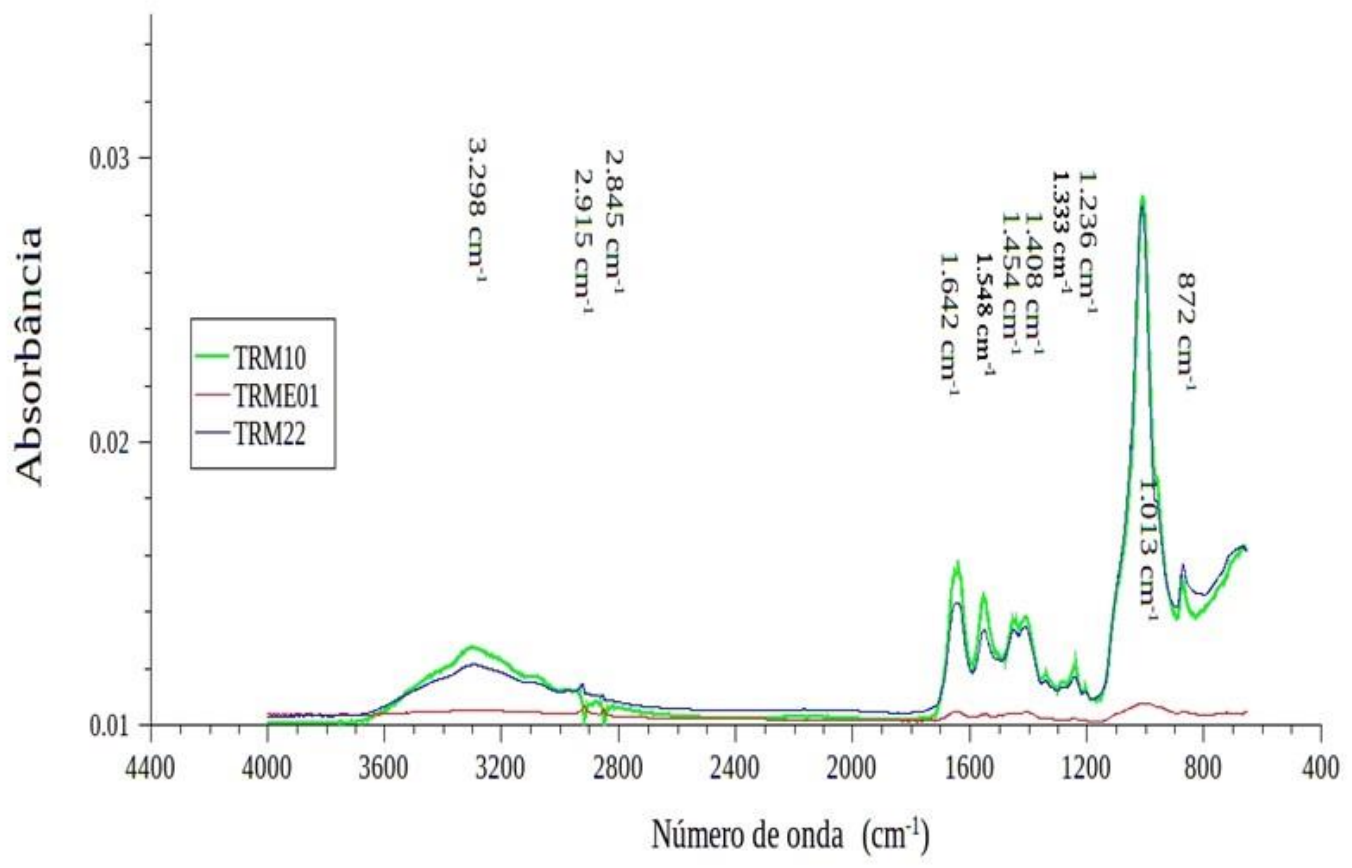

Fonte: Elaborado pelo autor no programa Labplot, Origin para Linux

A Figura 72 apresenta os espectros das amostras submetidas à irradiação gama (TRM44, TRM39, TRM37, TRM38) através de análise por reflexão total atenuada (ATR FTIR). Observa-se um comportamento similar entre as bandas obtidas em cada espectro, sendo que a intensidade dos picos de absorção desta varia levemente de uma amostra para outra. Por outro lado, notam-se os mesmos compostos orgânicos e inorgânicos detectados em todos os espectros e descritos anteriormente para o caso das amostras TRM02 e TRM07. 
Figura 72. Espectroscopia por absorção no infravermelho médio das amostras irradiadas da região do trígono retromolar

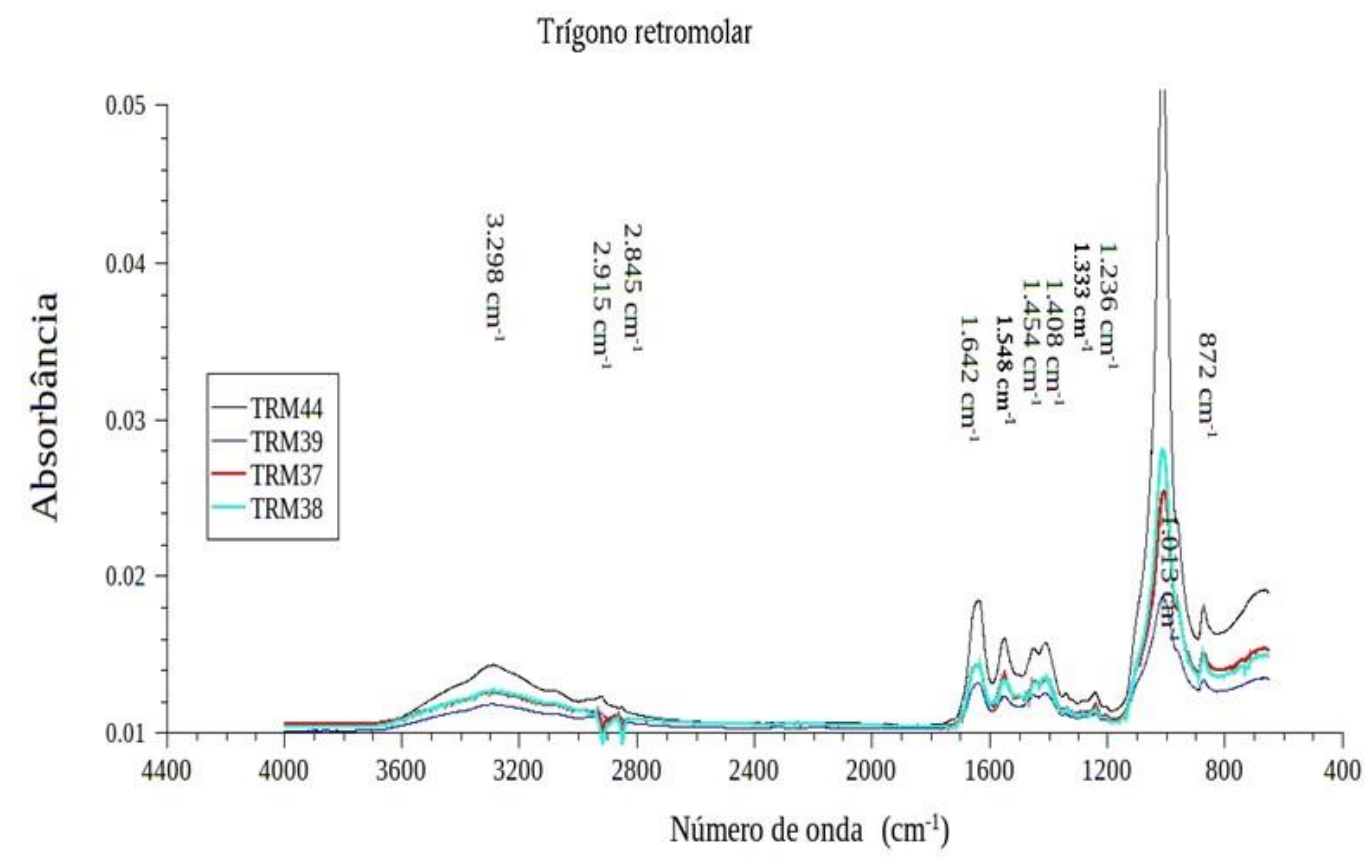

Fonte: Elaborado pelo autor no programa Labplot, Origin. para Linux 


\section{DISCUSSÃO}

Todas as amostras analisadas no presente estudo apresentaram os efeitos da radiação gama em diferentes graus. Estes efeitos, a partir dos resultados obtidos da microdureza de superfície, da microscopia eletrônica de varredura antes e após a radioterapia, e da análise bioquímica qualitativa executada através da técnica de reflexão total atenuada na espectroscopia no infravermelho por transformada de Fourier, constatou-se que tais efeitos exercidos pela radiação ionizante, a partir do protocolo de irradiação in vitro usado neste estudo, foram deletérios. Estatisticamente os resultados foram significantes (valor significante de $\mathrm{p}=0,00)$, no que diz respeito à análise comparativa entre os valores iniciais (antes da irradiação gama) e finais (após a irradiação gama com uma dose total de 72Gy, aplicada de forma fracionada), da microdureza de superfície. Salienta-se que estes resultados foram similares quando comparados com os da literatura, [12], [14], [17], [27] e [28].

Os resultados obtidos para cada grupo de estudo estão de acordo com a minuciosa revisão efetuada da literatura atual das sequelas da radioterapia nos pacientes com câncer de cabeça e pescoço e as complicações inerentes ao tratamento.

O principal objetivo deste estudo foi a avaliação dos efeitos ocorridos nos tecidos duros de forma exclusiva, no esmalte dentário, dentina radicular e o osso mandibular. A microdureza de superfície, por ser um indicador indireto do conteúdo mineral, [5] e [17], confirmou através da análise feita, a perda mineral em cada tecido através do valor Knoop. Essa técnica é usada em diferentes estudos pela sua precisão e confiabilidade, além de sua simples execução e aplicabilidade, [14], [26] e [27]. Fornece resultados variáveis para cada tecido, segundo os valores referenciais da literatura, [12], [13], [14], [15], [17] e [26]. Isso permite comparações e o estabelecimento de parâmetros estatísticos que indicam indiretamente o grau de acometimento na matriz inorgânica.

Os resultados no presente estudo, para o caso do esmalte dentário foram de ampla importância (valor de $\mathrm{p}=0,00$ ) com respeito à diminuição dos valores de microdureza após a irradiação gama quando comparados com os outros tecidos mineralizados, e divergem com outros resultados obtidos por outros autores, [14], [15], [17] e [26]. No entanto, no caso do grupo da dentina radicular observou-se uma leve superioridade dos valores obtidos na microdureza de superfície, quando comparados com os outros tecidos de maior conteúdo 
orgânico, tais como o corpo mandibular e o trígono retromolar, porém menores quando comparados com o esmalte dentário. Por outro lado, o grupo de corpo mandibular e a região do trígono retromolar apresentaram resultados muitos similares no que diz respeito à diferença dos valores iniciais e finais de microdureza de superfície. Não houve diferenças estatisticamente significativas, $(\mathrm{p}=0,97 \%)$, considerando-se os resultados como um efeito similar exercido pela radiação gama em ambos os tecidos.

O esmalte apresentou um maior valor da média da diferença dos valores de microdureza de superfície inicial e final, Figura 28, o que demonstra um maior acometimento da superfície de esmalte pela radiação gama, obtendo-se valores inferiores de microdureza final quando comparados com os valores iniciais.

Com respeito à dentina, obteve- se um valor da média menor, quando comparado com o esmalte e superior, quando comparado com as regiões de osso mandibular. Segundo a literatura recente, [14], [17] e [26], a dentina foi o tecido duro de maior acometimento e grau de destruição pela radiação gama, considerando-se a sua composição orgânica e inorgânica e um maior conteúdo de água quando comparado ao esmalte dentário, além da ação das proteinases e metálo-proteinases ativadas durante o processo destrutivo e de desnaturalização proteica, [6]. No presente estudo, a dentina radicular apresentou uma menor taxa de acometimento quando comparada com o esmalte. Alguns estudos, [17] e [26], apresentaram resultados similares, porém com um determinado limiar de dose empregada (para doses até de 30Gy houve uma perda de dureza maior do que em doses superiores).

O resultado apresentado neste estudo no que diz respeito ao esmalte dentário implicará uma revisão acurada e minuciosa visando a realização de estudos posteriores do efeito direto da radiação gama. Será necessária uma avaliação da modalidade de aplicação da radioterapia, do efeito sobre o esmalte dentário e a consequente perda de dureza do tecido causada pela desorganização físico-química, que poderá acarretar um rápido avanço nos tecidos subjacentes.

A cárie de radiação caracteriza-se pelo rápido avanço e destruição que ela produz nos dentes dos pacientes submetidos à radioterapia, e a necessidade da instauração de um tratamento de alta complexidade e de difícil manejo, além das sequelas físicas e psicológicas 
que aparecerão nestes pacientes, possivelmente justificados pelo fato da radioterapia exercer um efeito deletério no esmalte dentário, como demonstrado neste estudo.

A espectroscopia no infravermelho por transformada de Fourier tem se tornado uma ferramenta de múltipla aplicabilidade na área médica, especificamente na análise de tecidos cancerígenos, infarto do miocárdio, avaliação de tumores de pele (carcinoma espinho e basocelular), sendo vista como uma alternativa promissora para o diagnóstico de inúmeros transtornos que alterem a composição bioquímica dos tecidos submetidos a uma avaliação acurada, [48] e [51].

O presente estudo avaliou as amostras antes e após a radioterapia aplicada através de um estudo bioquímico e qualitativo com o emprego dos espectros obtidos da técnica de reflexão total atenuada pela espectroscopia no infravermelho por transformada de Fourier. A análise realizada em cada grupo de estudo visou descrever as mudanças de conteúdo na matriz orgânica e inorgânica, com o aparecimento ou desaparecimento das bandas de absorção na região espectral do infravermelho médio, sendo esta região absorvida pela maioria dos componentes dos tecidos duros da cavidade bucal, [50].

Basicamente, o esmalte dentário é constituído de poli-hidroxiapatita (97 \%), proteína (1\%), sendo elas ameloblastina, enamelina, amelogenina e água (2\%). As absorções na região do infravermelho do material analisado convergem para essa constituição, uma vez que foi verificada a presença do grupo fosfato e hidroxila, que são os grupos funcionais que constituem a poli-hidroxiapatita. Os grupamentos amida, ácido carboxílico, grupos oxigenados e de cadeia carbônica, constituem as proteínas formadoras das amostras e o grupo hidroxila em $3.425 \mathrm{~cm}^{-1}$ está relacionado à hidroxila que interage por ligações fracas de pontes de hidrogênio, como a água.

Na Figura 51, os grupos que foram absorbidos na amostra tratada foram aqueles mostrados nos espectros de esmalte descritos anteriormente neste estudo e na literatura, [50], salientando-se duas bandas analisadas a seguir: $1.536 \mathrm{~cm}^{-1}$, cujo pico de absorção apresenta uma deformação angular da ligação N-H, correspondente à amida II. Por outro lado, a região espectral em $1.000 \mathrm{~cm}^{-1}$, apresenta a absorção do grupo fosfato $\mathrm{PO}_{4}{ }^{3-}$ (matriz inorgânica). 
Essas bandas mostram que houve uma alteração bioquímica do material em função do processo de irradiação. A banda referente à amida II fica mais evidente e a que se refere à poli-hidroxiapatita torna-se mais intensa, sugerindo que os outros componentes, especificamente da matriz orgânica, podem ter se degradado, o que poderia neste caso evidenciar a presença da poli-hidroxiapatita.

Os resultados no caso da dentina radicular nas amostras controle concordaram com a composição inerente ao tecido, sabendo que é constituída de $18 \%$ de material orgânico (colágeno tipo I, lipídeos, citratos, glicoproteínas e proteoglicanos), $12 \%$ de água e $70 \%$ de material inorgânico (poli-hidroxiapatita e fosfatos de cálcio). A análise espectral evidenciou a parte orgânica do material mostrando as funções amida (I, II e III) característica da presença de colágeno tipo I, a base hidrocarbonada da cadeia orgânica que contém esses grupos, como encontrado em outros estudos, [48] e [51].

Na Figura 53 que mostra a comparação entre os espectros das amostras controle (D81REF, D52REF) e da amostra submetida à irradiação gama com uma dose total de 72Gy (D74 1708), observa-se alteração do espectro da amostra irradiada quando comparado com os espectros referenciais. Nesta figura é possível notar o desaparecimento das bandas referentes à presença de amida (I, II e III) e da poli-hidroxiapatita e intensificação das bandas em $2.923 \mathrm{~cm}^{-1}$ e $2.852 \mathrm{~cm}^{-1}$. A banda em $1.734 \mathrm{~cm}^{-1}$ é relativa à presença de peróxido. Esse comportamento evidencia a degradação do material quando exposto à radiação ionizante, onde há a deterioração do colágeno e da poli-hidroxiapatita. A presença de peróxidos evidencia a geração de produtos oxigenados altamente reativos e que são os responsáveis diretos pela degradação, [48] e [51].

As análises representam uma evidente alteração composicional nas amostras de dentina radicular submetidas à irradiação, constatando-se posteriormente diferenças que devem ser salientadas como o aparecimento e desaparecimento das bandas em $1.450 \mathrm{~cm}^{-1} \mathrm{e}$ $1.336 \mathrm{~cm}^{-1}$. Isto sugere que o processo de irradiação quebra o grupo carboxílico das amidas que constituem a parte orgânica dessa amostra. Desta forma, fica esclarecido o fato do desaparecimento das bandas e a diminuição da intensidade dos picos de absorção das amostras irradiadas quando comparadas com as amostras controle, o que demonstra claramente a relevância da técnica, já que evidencia a degradação do material orgânico e a 
desorganização do conteúdo mineral na dentina, incluindo a perda desse conteúdo, correlacionando esses resultados com os obtidos na análise de microdureza de superfície e a avaliação morfológica através da microscopia eletrônica de varredura.

As amostras do osso mandibular, de forma geral, mostraram as mesmas bandas de absorção na região do infravermelho verificadas na dentina. Resultados diferentes foram encontrados em outros estudos, [48] e [53]. O corpo mandibular é constituído por $65 \%$ de material inorgânico (poli-hidróxiapatita e fosfatos de cálcio), $25 \%$ de material orgânico (fibras de colágeno tipo I) e $10 \%$ de água, guardando semelhança composicional em relação à dentina. No entanto, a presença das bandas em $1.445 \mathrm{~cm}^{-1}$, referente ao grupo -OH do ácido carboxílico, $1.336 \mathrm{~cm}^{-1}$ relativo ao grupo -CO do ácido carboxílico e $1.239 \mathrm{~cm}^{-1}$ relativo ao grupo -NH (amida III) são fracos e menos evidentes que na dentina. Resultados similares foram encontrados os estudos recentes, [48] e [51].

A análise aprofundada do terceiro gráfico correspondente ao corpo mandibular evidencia a completa alteração do espectro da amostra irradiada quando comparado com os espectros referenciais, visualizando-se o desaparecimento das bandas em $3.291 \mathrm{~cm}^{-1}$, $1.643 \mathrm{~cm}^{-1}, 1.553 \mathrm{~cm}^{-1}, 1.41 \mathrm{~cm}^{-1}, 1.012 \mathrm{~cm}^{-1}$ e $865 \mathrm{~cm}^{-1}$. Surgem novas bandas em $2.923 \mathrm{~cm}^{-1}$, $2.852 \mathrm{~cm}^{-1}$, referentes à cadeia hidrocarbonada dos constituintes orgânicos. Na região espectral $1.734 \mathrm{~cm}^{-1}$ é relativa à presença de peróxido, em $1.445 \mathrm{~cm}^{-1}$, relativo ao grupo $-\mathrm{OH}$ do ácido carboxílico, em $1.336 \mathrm{~cm}^{-1}$ relativo ao grupo -CO do ácido carboxílico e em 715 $\mathrm{cm}^{-1}$, devido à deformação angular fora do plano do grupo $\mathrm{O}-\mathrm{H}$ ligado por pontes de hidrogênio do material fosfatado. Toda essa alteração evidencia a degradação, não só da parte orgânica que forma a amostra, como também a desagregação da parte inorgânica, com forte ação da oxidação provocada pela presença de substâncias altamente reativas e oxidantes como o peróxido. No que diz respeito à comparação dos espectros das amostras controle e da amostra irradiada, na Figura 58, observa-se uma diminuição da intensidade nas bandas em $3.291 \mathrm{~cm}^{-1}$ e $1.012 \mathrm{~cm}^{-1}$ relativas respectivamente ao grupo $-\mathrm{OH}$ presente nas substâncias que interagem por pontes de hidrogênio e ao grupo $\mathrm{PO}_{4}{ }^{3-}$ da poli-hidroxiapatita, além do surgimento de novas bandas em $2.917 \mathrm{~cm}^{-1} \mathrm{e} 2.851 \mathrm{~cm}^{-1}$ relativas à cadeia hidrocarbonada dos materiais orgânicos e em $715 \mathrm{~cm}^{-1}$, devido à deformação angular fora do plano do grupo O- 
H ligado por pontes de hidrogênio do material fosfatado. Nesse caso o processo de irradiação atuou de modo a degradar a matéria orgânica e inorgânica da amostra.

Por outro lado, com relação à análise espectral das amostras de corpo mandibular, na Figura 64, o espectro dos gráficos do material irradiado é semelhante ao dos materiais não irradiados. No entanto, evidencia-se o surgimento das bandas em $2.917 \mathrm{~cm}^{-1}$ e $2.851 \mathrm{~cm}^{-1}$ relativas à cadeia hidrocarbonada dos materiais orgânicos, sugerindo que nesse material houve pequena modificação devido ao processo de irradiação.

Ao se analisar cada espectro correspondente à região do trígono retromolar, deve-se considerar: a região do trígono retromolar apresenta uma composição semelhante ao do corpo mandibular, [49], porém com percentagem menor de material inorgânico (poli-hidroxiapatita e fosfatos de cálcio) e um maior conteúdo de material orgânico (fibras de colágeno tipo I) e com quantidade similar de água. Os resultados apresentados por esses espectros estão de acordo com a literatura, [49] e [50].

As análises executadas no decorrer do presente estudo avaliaram as consequências da aplicação de uma determinada dose de radiação ionizante sobre as amostras previamente padronizadas dos tecidos duros da cavidade bucal, de forma isolada, e sem os fatores locais contribuintes ao aparecimento dos efeitos indesejáveis, inerentes e alheios à radiação gama.

Determinou-se a ação direta desta através da análise física de conteúdo mineral, composicional por meio dos espectros pela transformada de Fourier e complementado e constatando-se as alterações morfológicas de superfície através da microscopia eletrônica de varredura. Cada análise manteve-se inter-relacionada com os resultados obtidos, seja nas variações de conteúdo mineral ou no decréscimo dos componentes orgânicos próprios da matriz orgânica de cada tecido analisado. Por outro lado, a microscopia eletrônica de varredura confirmou os resultados encontrados quantitativa e qualitativamente na análise de microdureza e no FTIR, respectivamente.

As transformações de caráter bioquímico e modificações ultra-estruturais, além de maior especificidade de resultados no que diz respeito à fisiopatologia desencadeada pela radiação gama e a interação com os tecidos duros permanece ainda não esclarecida. Assim, serão necessários maiores estudos com técnicas inovadoras, tais como as técnicas de biologia 
molecular e afins, de tipo quantitativa para determinar-se dados exatos sobre a quantidade de progressão destes efeitos deletérios da radiação gama nos tecidos duros da cavidade bucal, especificamente na repercussão e o possível acometimento dos tecidos moles e estruturas glandulares circunvizinhas.

Comprovou-se que a radiação gama per se produz efeitos de alta relevância na composição e estrutura dos tecidos analisados, e que o seu efeito de forma isolada, conforme os resultados apresentados neste estudo deverão ser considerados pelo oncologista, radioterapeuta e a equipe multidisciplinar encarregada do cuidado do paciente oncológico. 


\section{CONCLUSÕES}

A partir dos resultados obtidos conclui-se do presente estudo:

1. A radiação gama exerceu um efeito deletério nos tecidos duros da cavidade bucal, demonstrado in vitro e constatado através da perda de microdureza de superfície, alterações morfológicas evidenciadas pela microscopia eletrônica, e nas alterações da composição bioquímica, tanto na matriz inorgânica quanto na orgânica detectadas pela técnica de reflexão total atenuada pela espectroscopia no infravermelho por transformada de Fourier.

2. As análises por meio da microscopia eletrônica de varredura evidenciaram as mudanças morfológicas após a irradiação gama quando as imagens iniciais foram comparadas com as finais, o que determinou o grau de acometimento no que diz respeito à superfície da amostra analisada, através de trincas, linhas de fratura e quebras do tecido duro.

3. A radiação ionizante acometeu em um maior grau o esmalte dentário no que diz respeito à perda de microdureza de superfície deste tecido demonstrado estatisticamente com um valor de $\mathrm{p}=0,00$, para a diferença das médias dos valores inicias e finais de microdureza, tanto intragrupo quanto intergrupo.

4. Os tecidos duros de maior conteúdo orgânico tais como a dentina e as regiões do osso mandibular analisadas, também apresentaram diferenças significantes entre os valores de microdureza inicial e final obtidas, intra e intergrupo no caso da dentina. Para o caso do corpo mandibular e região do trígono retromolar só apresentaram diferenças significativas intragrupo, e referente ao esmalte e a dentina.

5. Após a análise da composição bioquímica dos quatro grupos através da espectroscopia no infravermelho antes e depois do processo de irradiação mostraram-se características diferentes entre eles: a dentina radicular e o corpo mandibular apresentaram degradação em todos os compostos analisados, a qual foi desencadeada pela produção de peróxidos provenientes da radiólise da água; a região trígono retromolar, as amostras apresentaram elevada degradação da água e das proteínas associadas à presença do colágeno; os compostos inorgânicos presentes apresentaram regiões de baixa degradação e o esmalte sofreu mudanças nos compostos inorgânicos e nas proteínas, mas verificou-se que a remoção de água teve lugar neste caso. 
6. A partir destes resultados pôde-se estabelecer uma conclusão geral do presente estudo, salientando-se o efeito direto da radiação ionizante, no caso, a irradiação como fator determinante e contribuinte à perda das propriedades físicas, composicional e morfológicas dos tecidos duros submetidos à radioterapia convencional, a partir de um modelo in vitro, dos pacientes acometidos por câncer de cabeça e pescoço, o que favorece, de fato, o aparecimento dos efeitos indesejáveis desta modalidade terapêutica, independente dos fatores contribuintes locais ou sistêmicos. 


\section{REFERÊNCIAS}

[1] INCA, "Instituto Nacional do Cancer no Brasil," 2015. [Online]. Available: http://www.inca.gov.br/wcm/dncc/2015/dados-apresentados.pdf. [Acesso em 17 Novembro 2016].

[2] INCA, "Instituto Nacional do Cancer José Alencar Gomes da Silva," 2014. [Online]. Available: http://www.saude.sp.gov.br/resources/ses/perfil/gestor/homepage/outrosdestaques/estimativa-de-incidencia-de-cancer-2014/estimativa_cancer_24042014.pdf. [Acesso em 17 Dezembro 2016].

[3] F. Carini, C. Bucalo, V. Saggese, D. Monai e G. Porcaro, "Case control study to assess the possibility of decrease the risk of osteoradionecrosis in relation to the dose of radiation absorbed by the jaw," Annali di stomatologia, vol. 3, p. 3, 2012.

[4] N. Grimaldi, V. Sarmento, L. Provedel, D. Almeida e S. Cunha, "Dental care in prevention and treatment of osteoradionecrosis: literature review," Rev Bras Cancerol, vol. 51, pp. 319-324, 2005.

[5] C. B. Zamataro, A. A. P. Benetti, C. Zezell e D. Maria, "Influence of Er, Cr: YSGG Laser on CaF2-like products formation because of professional acidulated fluoride or to domestic dentifrice application," Microscopy research and technique, vol. 76, $\mathrm{n}^{\circ} 7$, pp. 704-713, 2013.

[6] J. McGuire, A. Mousa, B. Zhang, L. Todoki, N. Huffman, K. Chandrababu, J. Moradian-Oldak, A. Keightley, Y. Wang e M. Walker, "Extracts of irradiated mature human tooth crowns contain MMP-20 protein and activity," Journal of dentistry, vol. $42, \mathrm{n}^{\circ} 5$, pp. 626-6352014.

[7] S. B. Kadam, S. K. Shyama e V. G. Almeida, "Evaluation of the in vivo genotoxic effects of gamma radiation on the peripheral blood leukocytes of head and neck cancer patients undergoing radiotherapy," Mutation Research/Genetic Toxicology and Environmental Mutagenesis, vol. 752, nº 1, pp. 42-46, 2013. 
[8] J. Mellberg, "Hard-tissue substrates for evaluation of cariogenic and anti-cariogenic activity in situ.," Journal of dental research, vol. 71, 1992.

[9] F. Arbabzadeh, E. Birang, R. Nazem, M. Abbasian, F. Koosha e R. Birang, "A Comparative Study on Micro Hardness and Structural Changes of Dentin Floor Cavity Prepared by Er: YAG Laser Irradiation and Mechanical Bur,” Journal of Dentistry, vol. $14, \mathrm{n}^{\mathrm{o}} 2$, p. 73, 2013.

[10] T. Koulourides, "Dynamics of tooth surface-oral fluid equilibrium," Adv Oral Bio, vol. 2, pp. 149-171, 1966.

[11] E. Kitajima e B. Leite, "Curso introdutório de microscopia eletrônica de varredura," Escola Superior de Agricultura Luiz de Queiroz, vol. 37, nº 2, 1997.

[12] J. De Dios Teruel, A. Alcolea, A. Hernández, A. Ruiz e J. Ortiz, “Comparison of chemical composition of enamel and dentine in human, bovine, porcine and ovine teeth," Archives of Oral Biology, vol. 60, no 5, pp. 768-775, 2015.

[13] A. A. Kunin, A. Y. Evdokimova e N. S. Moiseeva, “Age-related differences of tooth enamel morphochemistry in health and dental caries," EPMA Journal, vol. 6, p. 1, 2015.

[14] R. Reed, C. Xu, Y. Liu, J. Gorski, Y. Wang e M. Walker, "Radiotherapy effect on nanomechanical properties and chemical composition of enamel and dentine," Archives of Oral Biology, vol. 60, n 5, pp. 690-697, 2015.

[15] J. Arsecularatne e M. Hoffman, "An in vitro study of the microstructure, composition and nanoindentation mechanical properties of remineralizing human dental enamel," Journal of Physics D: Applied Physics, vol. 47, pp. 315-403, 2014.

[16] A. Veis, "Mineral-matrix interactions in bone and dentin," Journal of Bone and Mineral Research, vol. 8, nº S2, pp. S493-S497, 1993.

[17] L. M. N. Gonçalves, R. G. Palma-Dibb, F. W. G. Paula-Silva, H. F. d. Oliveira, P. Nelson-Filho, L. A. B. d. Silva e A. M. d. Queiroza, "Radiation therapy alters 
microhardness and microstructure of enamel and dentin of permanent human teeth," Journal of Dentistry, vol. 42, nº 8, pp. 986-992, 2014.

[18] K. Chun, H. Choi e J. Lee, "Comparison of mechanical property and role between enamel and dentin in the human teeth," Journal of Dental Biomechanics, vol. 5, pp. 17, 2014.

[19] M. N. Veloso, “Avaliação in vitro dos efeitos da radiação ionizante em tecido ósseo bovino por espectroscopia ATR-FTIR e análise dinámico-mecânica,” Instituto de Pesquisas Energéticas e Nucleares - Universidade de São Paulo , São Paulo, 2013.

[20] C. Luciano, “Densitometria óssea em mandíbula de suínos submetidos a enxerto ósseo autógeno, homógeno e heterógeno," UNESP, Araçatuba, 2006.

[21] B. Tymczyna, M. R. Tatara, W. Krupski, M. Tymczyna-Sobotka, I. LuszczewskaSierakowska e T. Bachanek, "Relationships between biochemical bone metabolism indices and morphometric, densitometric and mechanical properties of mandible in 6month-old pigs," Annals of Agricultural and Environmental Medicine, vol. 19, no 3, 2012.

[22] Y. Li, J. Xu, L. Mao, Y. Liu, R. Gao, Z. Zheng, W. Chen, A. Le, S. Shi e S. Wang, "Allogeneic mesenchymal stem cell therapy for bisphosphonate-related jaw osteonecrosis in Swine," Stem cells and development, vol. 22, n 14, pp. 2047-2056, 2013.

[23] T. Brosh, D. Rozitsky, S. Geron e R. Pilo, “Tensile Mechanical Properties of Swine Cortical Mandibular Bone," PloS one, vol. 9, n 12, pp. 113-229, 2014.

[24] H.-S. Lin, Y.-J. Chen, J.-D. Li, T.-W. Lu, H.-H. Chang e C.-C. Hu, "Measurement of mandibular growth using cone-beam computed tomography: a miniature pig model study," PloS one, vol. 9, nº 5, pp. 1-10, 2014.

[25] A. Pearce, R. Richards, S. Milz, E. Schneider e S. Pearce, “Animal models for implant biomaterial research in bone: a review," Eur Cell Mate, vol. 13, nº 1, pp. 1-10, 2007. 
[26] H. Lieshout e C. Bots, "The effect of radiotherapy on dental hard tissue-a systematic review," Clinical oral investigations, vol. 18, nº 1, pp. 17-24, 2014.

[27] P. Qing, S. Huang, S. Gao, L. Qian e H. Yu, "Effect of gamma irradiation on the wear behaviour of human tooth enamel," Scientific reports, vol. 5, 2015.

[28] J. Deng, L. Jackson, J. B. Epstein, C. A. Migliorati e B. A. Murphy, "Dental demineralization and caries in patients with head and neck cancer," Oral oncology, vol. 51, nº 9, pp. 824-831, 2015.

[29] A. Vissink, J. Jansma, F. Spijkervet, F. Burlage e R. Coppes, "Oral sequelae of head and neck radiotherapy," Critical Reviews in Oral Biology $\backslash \&$ Medicine, vol. 14, $\mathrm{n}^{\circ} 3$, pp. 199-212, 2003.

[30] N. El-Faramawy, R. Ameen, K. El-Haddad e M. El-Zainy, "Effects of gamma radiation on hard dental tissues of albino rats: investigation by light microscopy," Radiation and environmental biophysics, vol. 52, nº 3, pp. 375-383, 2013.

[31] B. D. Loucas, M. Durante, S. M. Bailey e M. N. Cornforth, "Chromosome damage in human cells by $\gamma$ rays, $\alpha$ particles and heavy ions: track interactions in basic doseresponse relationships," Radiation research, vol. 179, nº 1, pp. 9-20, 2012.

[32] T. Kawata, H. Ito, K. George, H. Wu e F. A. Cucinotta, "Chromosome aberrations induced by high-LET radiations," Biological Sciences in Space, vol. 18, n 4, pp. 216223, 2004.

[33] L. TAUHATA, P. SALATI, R. DI PRINZIO e A. DI PRINZIO, "Radioproteção e Dosimetria: Fundamentos, Instituto de Radioproteção e Dosimetria," Comissão Nacional de Energia Nuclear, $\mathrm{n}^{\circ}$ 5, 2003.

[34] A. Wojcik, E. Gregoire, I. Hayata, L. Roy, S. Sommer, G. Stephan e P. Voisin, "Cytogenetic damage in lymphocytes for the purpose of dose reconstruction: a review of three recent radiation accidents," Cytogenetic and genome research, vol. 104, $\mathrm{n}^{\mathrm{o}} 1$ 4, pp. 200-205, 2004. 
[35] T. Hadley, C. Song, L. Wells, J. Lehnhardt, M. W. Rogers, J. Anderson, M. Terry, B. Novy e T. Lo, "Does hyperbaric oxygen therapy have the potential to improve salivary gland function in irradiated head and neck cancer patients?," Medical gas research, vol. $3, n^{\circ} 1$, pp. 1-5, 2013.

[36] A. Gevorgyan, K. Wong, I. Poon, N. Blanas, D. J. Enepekides e K. M. Higgins, "Osteoradionecrosis of the mandible: a case series at a single institutio," Journal of Otolaryngology-Head $\backslash \&$ Neck Surgery, vol. 42, nº 1, pp. 1-7, 2013.

[37] M. Niewald, J. Fleckenstein, K. Mang, H. Holtmann, W. J. Spitzer e C. Rübe, "Dental status, dental rehabilitation procedures, demographic and oncological data as potential risk factors for infected osteoradionecrosis of the lower jaw after radiotherapy for oral neoplasms: a retrospective evaluation," Radiation Oncology, vol. 8, nº 1, 2013.

[38] T. Reuther, T. Schuster, U. Mende e A. Küblerc, "Osteoradionecrosis of the jaws as a side effect of radiotherapy of head and neck tumour patients - a report of a thirty year retrospective review," International journal of oral and maxillofacial surgery, vol. 32, n 3, pp. 289-295, 2003.

[39] J. J. Freiberger, D. S. Yoo, G. de Lisle Dear, T. A. McGraw, G. H. Blakey, R. P. Burgos, K. Kraft, J. W. Nelson, R. E. Moon e C. A. Piantadosi, "Multimodality surgical and hyperbaric management of mandibular osteoradionecrosis," International Journal of Radiation Oncology Biology Physics, vol. 75, n 3, pp. 712-724, 2009.

[40] I. J. Lee, W. S. Koom, C. G. Lee, Y. B. Kim, S. W. Yoo, K. C. Keum, G. E. Kim, E. C. Choi e I. H. Cha, "Risk factors and dose--effect relationship for mandibular osteoradionecrosis in oral and oropharyngeal cancer patients," International Journal of Radiation Oncology* Biology* Physics, vol. 75, n 4, pp. 1084-1091, 2009.

[41] J. V. Bagan, Y. Jiménez, S. Hernández, J. Murillo, J. M. Díaz, R. Poveda, E. Carbonell, J. M. Sanchis, C. Gavaldá e C. Scully, "Osteonecrosis of the jaws by intravenous bisphosphonates and osteoradionecrosis: a comparative study," Med Oral Patol Oral Cir Bucal, vol. 14, n 12, pp. e616-9, 2009. 
[42] M. Tamplen, K. Trapp, I. Nishimura, B. Armin, M. Steinberg, J. Beumer, E. Abemayor e V. Nabili, "Standardized analysis of mandibular osteoradionecrosis in a rat model," Otolaryngology--Head and Neck Surgery, 2011.

[43] C. Madrid, M. Abarca e K. Bouferrache, "Osteoradionecrosis: an update," Oral oncology, vol. 46, nº 6, pp. 471-474, 2010.

[44] F. Jegoux, O. Malard, E. Goyenvalle, E. Aguado e G. Daculsi, "Radiation effects on bone healing and reconstruction: interpretation of the literature," Oral Surgery, Oral Medicine, Oral Pathology, Oral Radiology, and Endodontology, vol. 109, nº 2, pp. 173 $184,2010$.

[45] Q. Zhuang, Z. Zhang, H. Fu e J. H. Y. He, "Does radiation-induced fibrosis have an important role in pathophysiology of the osteoradionecrosis of jaw?," Medical hypotheses, vol. 77, $\mathrm{n}^{\mathrm{o}} 1$, pp. 63-65, 2011.

[46] M. M. Curi, C. L. Cardoso, H. G. de Lima, L. P. Kowalski e M. D. Martins, "Histopathologic and Histomorphometric Analysis of Irradiation Injury in Bone and the Surrounding Soft Tissues of the Jaws," Journal of Oral and Maxillofacial Surgery, vol. 74, no 1, pp. 190-199, 2016.

[47] M. M. Curi, M. O. dos Santos, O. Feher, J. C. M. Faria, M. L. Rodrigues e L. P. Kowalski, "Management of extensive osteoradionecrosis of the mandible with radical resection and immediate microvascular reconstruction," Journal of oral and maxillofacial surgery, vol. 65, nº 3, pp. 434-438, 2007.

[48] D. M. Zezell, C. Benetti, M. N. Veloso, P. A. Castro e P. A. Ana, "FTIR Spectroscopy Revealing the Effects of Laser and Ionizing Radiation on Biological Hard Tissues," Journal of the Brazilian Chemical Society, vol. 26, nº 12, pp. 2571-2582, 2015.

[49] M. Figueiredo, A. Martins e J. Gamelas, "Characterization of bone and bone-based graft materials using FTIR spectroscopy,” INTECH Open Access Publisher, 2012. 
[50] R. M. Silverstein, F. X. Webster e D. J. Kiemle, Identificação Espectrometrica de Compostos Organicos, Rio de Janeiro : Biblioteca do CPqRR, 2007.

[51] D. Magne, P. Weiss, J.-M. Bouler, O. Laboux e G. Daculsi, "Study of the maturation of the organic (type I collagen) and mineral (nonstoichiometric apatite) constituents of a calcified tissue (dentin) as a function of location: a Fourier transform infrared microspectroscopic investigation," Journal of Bone and Mineral Research, vol. 16, $\mathrm{n}^{\mathrm{o}}$ 4, pp. 750-757, 2001.

[52] D. De Lima Pereira, "Uso de técnicas ópticas no monitoramento dos efeitos do laser de Nd:YAG sobre a erosão dentária," Santo André - São Paulo, 2014.

[53] Y. Sa, S. Liang, X. Ma, S. Lu, Z. Wang, T. Jiang e Y. Wang, “Compositional, structural and mechanical comparisons of normal enamel and hypomaturation enamel," Acta biomaterialia\}, vol. 10, nº 12, pp. 5169-5177, 2014.

[54] A. C. B. de Cara, D. M. Zezell, P. A. Ana, A. M. Deana, M. M. Amaral, N. D. Vieira Jr e A. Z. de Freitas, "Comparative analysis of optical coherence tomography signal and microhardness for demineralization evaluation of human tooth enamel," em SPIE Photonics Europe, International Society for Optics and Photonics , 2012, pp. 84271H$84271 \mathrm{H}$. 


\begin{abstract}
ANEXO A
A planilha a seguir foi utilizada para coleta de dados de microdureza de superfície inicial e final. Além disso, foi inserida a porcentagem de perda de dureza. Foram feitas três fileiras de cinco indentações cada, com distância de $100 \mu$ m entre as indentações e com uma distância de $200 \mu \mathrm{m}$ entre as fileiras.
\end{abstract}

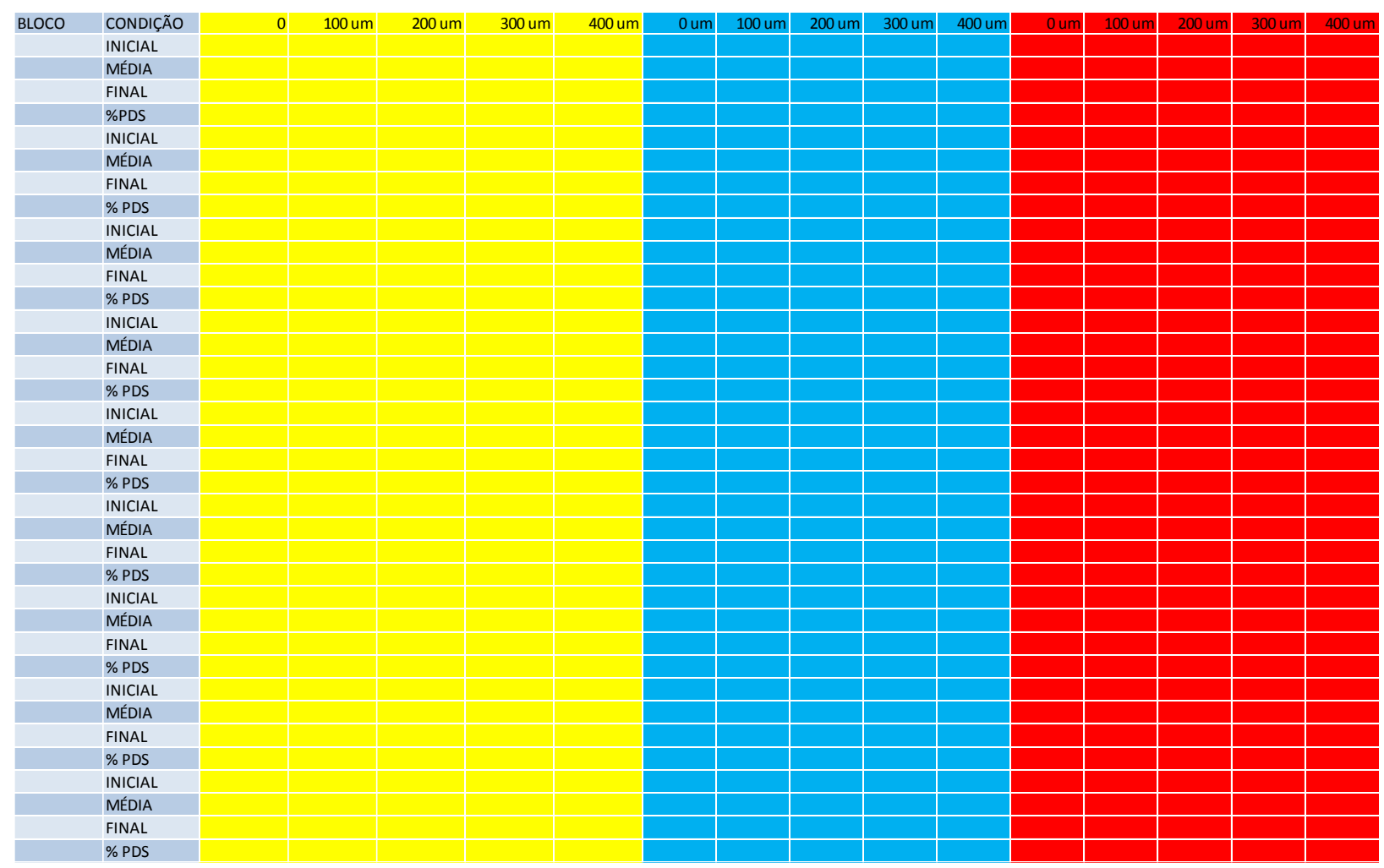

